\title{
Urban water management reform : the case of China
}

Citation for published version (APA):

Zhao, J. (2015). Urban water management reform : the case of China. [Doctoral Thesis, Maastricht University]. Datawyse / Universitaire Pers Maastricht. https://doi.org/10.26481/dis.20150225jz

Document status and date:

Published: 01/01/2015

DOI:

10.26481/dis.20150225jz

Document Version:

Publisher's PDF, also known as Version of record

\section{Please check the document version of this publication:}

- A submitted manuscript is the version of the article upon submission and before peer-review. There can be important differences between the submitted version and the official published version of record.

People interested in the research are advised to contact the author for the final version of the publication, or visit the DOI to the publisher's website.

- The final author version and the galley proof are versions of the publication after peer review.

- The final published version features the final layout of the paper including the volume, issue and page numbers.

Link to publication

\footnotetext{
General rights rights.

- You may freely distribute the URL identifying the publication in the public portal. please follow below link for the End User Agreement:

www.umlib.nl/taverne-license

Take down policy

If you believe that this document breaches copyright please contact us at:

repository@maastrichtuniversity.nl

providing details and we will investigate your claim.
}

Copyright and moral rights for the publications made accessible in the public portal are retained by the authors and/or other copyright owners and it is a condition of accessing publications that users recognise and abide by the legal requirements associated with these

- Users may download and print one copy of any publication from the public portal for the purpose of private study or research.

- You may not further distribute the material or use it for any profit-making activity or commercial gain

If the publication is distributed under the terms of Article $25 \mathrm{fa}$ of the Dutch Copyright Act, indicated by the "Taverne" license above, 
(C) Copyright Jinjin Zhao, Maastricht 2015

ISBN 9789461594143 


\title{
Urban water management reform: The case of China
}

\author{
DISSERTATION \\ to obtain the degree of doctor at Maastricht University, \\ on the authority of the Rector Magnificus Prof. dr. L.L.G. Soete, \\ in accordance with the decision of the Board of Deans,
} to be defended in public on Wednesday 25 February, 2015, at 12:00 hours.

by

Jinjin Zhao

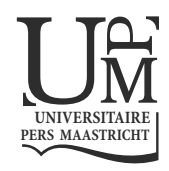




\section{Supervisors}

Prof. dr. Luc L.G. Soete

Prof. dr. Gerlach Cerfontaine

\section{Assessment Committee}

Prof. dr. Pierre Mohnen (Chairman)

Prof. dr. Shyama V. Ramani

Prof. dr. Zhong Ma, Renmin University of China, P. R. China

Dr. Dorcas Mbuvi, UNU-MERIT, the Netherlands 


\section{Acknowledgements}

The journey of pursuing a doctor degree is both painful and enjoyable. It is just like climbing a high mountain, step by step, accompanied with bitterness, hardships, frustration, encouragement, trust and helps. Undertaking this journey has been a truly life-changing experience for me. When I found myself at the top enjoying the beautiful scenery, I realized that it would not have been possible to do without the support and guidance from many people.

I would like to express my special appreciations and thanks to my two supervisors, Professor dr. Luc L.G. Soete and Professor dr. Gerlach Cerfontaine. Both of them have been tremendous mentors for me. Without their encouragement and patient guidance and supervisions, this $\mathrm{PhD}$ would not have been achievable.

I would like to thank Professor dr. Pierre Mohnen, Professor dr. Shyama V. Ramani, Professor dr. Zhong Ma and Dr. Dorcas Mbuvi for serving as my committee members. I also want to thank them for letting my defense be an enjoyable moment, and for their brilliant comments and suggestions.

I would especially like to thank all my colleagues and friends in UNU-MERIT, Maastricht University. All of them have been there to support me. Special thanks are given to Prof. dr. Pierre Mohnen, who provided me invaluable advices and suggestions on my research. His critical comments enabled me to notice the weaknesses of my dissertation and make the necessary improvements. Many thanks are given to Prof. dr. Shyama V. Ramani and Prof. dr. Adam Szirmai, who enlightened my way of thinking and offered me valuable advices. I also would like to express my thanks to Dr. Michiko Iizuka, Dr. Dorcas Mbuvi, Dr. Jojo Jacob and Dr. Sutapa Chattopadhyay for providing me lots of useful information and kind helps on my research. Special thanks are also given to Wilma Coenegrachts, for her kind helps, encouragements and supports, which made me feel confident to fulfill my desire and to overcome every difficulty I encountered. Many sincere thanks to Eveline in de Braek, for all her kind helps and guiding me through the last section of my PhD journey, which made my PhD journey ended smoothly and successfully. I would also like to thank Marc Velugels, Eric Engelen, Herman Pijpers, Mourik Jan Heupink, Ad Notten, Howard Hudson, Monique Raedts, Mitie Stenders and Han Hoogma, for all their supports and helps on my research.

My sincere thanks go to all the persons who have offered me their time and helps when I collected necessary data for my research. Special thanks are given to Prof. dr. Yuejun Zheng of Doshisha University, who provided me invaluable data and advices on environmental awareness research. I would like to thank all the following persons who offered great helps on data collection of my research, including Claire Nauwelaers, Aziza Akhmouch and Lillian Grabill (OECD), Yosuke Tomizawa (Water Resource Department, Ministry of Land, Infrastructure, Transport and Tourism, Japan), Yosuke Matsumiya (Engineering Department Japan Sewage Works 
Association), Midori Tani (Ministry of Economy, Trade and Industry Japan), Takatoshi Wako (Environmental Management Bureau, Ministry of the Environment, Japan)Ted Czado, Susan Poulsom and Michael Le (EPA US), Jon Russell, Anna Goss, Jonathan Tyas, Dan Haigh, Ben Bradford and Joanne Walker (The Environment Agency, UK), Bob Bhardwaj and Helen Smith (Department for communities and Local Government, UK), Luigi FAbiano (IStat, Italy), Simone Richter (UmweltBundesamt, Germany), Melanie Bodenseh (Statistisches Bundesamt, Germany), Johannes Wendang (Federal Ministry for the Envrionment, Germany), Michel Villeneuve, Andres De Vleeschauwer and Chantale Cerny (Environment Canada), Laurent Zecha and Corinne Di Loreto (Swiss Statistics), Patrick Fischer (Federal Office for Envrionment, Swiss), Stephan Bader (Federal Office of Meteorology and Climatology Meteo Swiss), Marcus Vingren and Jerker Moström (Statistics Sweden), Torny Axell (Swedish Meteorological and Hydrological Institute), Steven Dubaere (FOD Economie, Belgium), Dennis Hansen (Statistics Denmark), Elisa Salomaa (Statistics Finland), Sacha Baud (Statistics Austria), Elaine Fouhy (The National Institute of Water and Atmospheric Research, New Zealand), Diana Fan (Statistics New Zealand), David de Jager (Ministry of Health, New Zealand), Elisabeth Widung and Anne Greiveldinger (Statistics Luxembourg), Henri Hansen (Administration de la gestion de l'eau, Luxembourg), Håkon Torfinn Karlsen and Gisle Berge (Statistics Norway), Marianne Bruusgaard (Ministry of Environment, Norway), Linda Deegan and Doireann Nicholls (Environmental Protection Agency, Ireland), Mark Lound and Steve May (Australian Bureau of Statistics).

I would also like to thank all of my friends who supported me in writing, and incented me to strive towards my goal. A special thanks to my family, my parentsin-law and my parents. Their supports for me were what sustained me thus far. At the end I would like to express my appreciations and thanks to my beloved husband Can Huang, who was always my support in the moments when there was no one to answer my queries. Words cannot express how grateful I am to him for all of the sacrifices that he has made for me. 


\section{Contents}

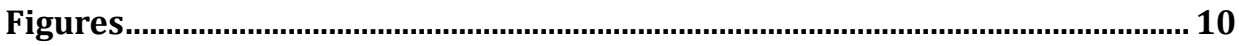

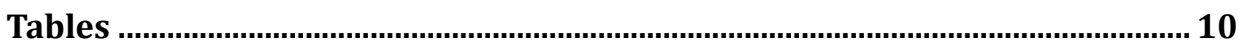

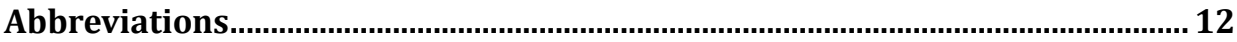

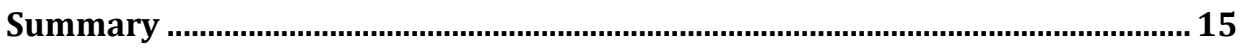

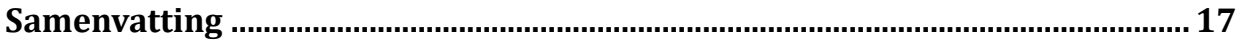

\section{CHAPTER 1}

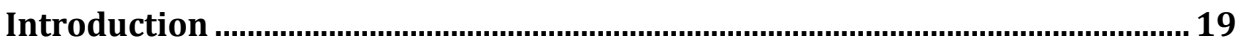

1.1 Research Background ..............................................................................................2

1.2 Structure and Contributions...............................................................................2

\section{CHAPTER 2}

The Cubic Water Kuznets Curve: The Determinants of Urban Water

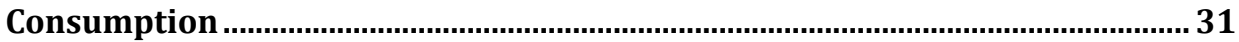

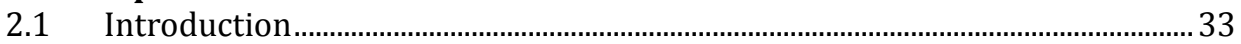

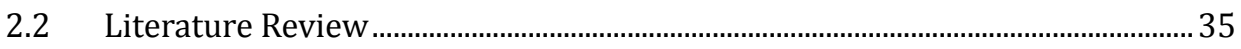

2.2.1 Environmental Kuznets Curves and Water Consumption ......................................... 35

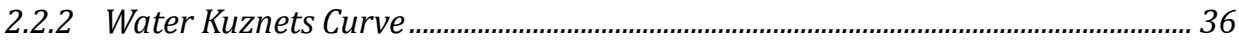

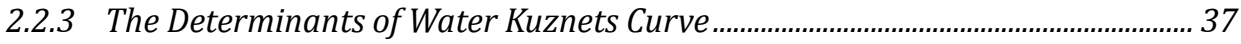

2.2.4 Urban Water Management and Water Policies........................................................ 39

2.3 Empirical Analysis...................................................................................................... 43

2.3.1 The Cubic Water Kuznets Curve …………………………............................................ 43

2.3.2 The Cubic Water Kuznets Curve Regression to Test Policy Effects......................... 43

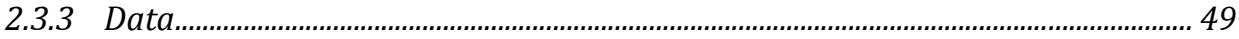

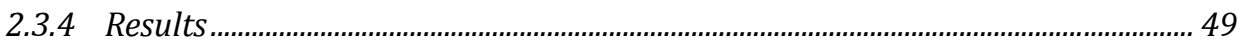

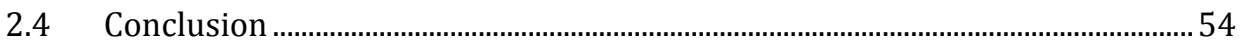

\section{CHAPTER 3}

The reform of urban water management in China .............................................57

3.1 Introduction...................................................................................................59

3.2 Pre-reform Urban Water Management in China......................................................6 60

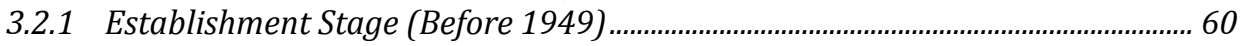

3.2.2 Construction and Formation Stage (1949-1978)...................................................... 61

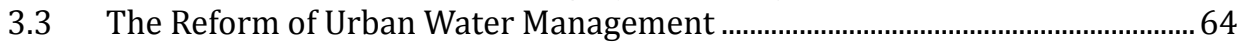

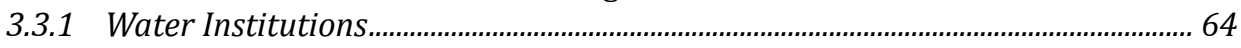

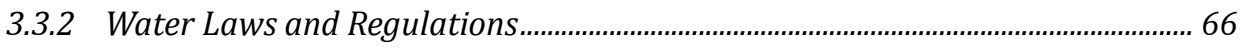

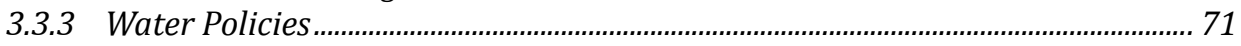

3.3.3.1 Supply Side Management-Privatization ........................................................................................ 73

3.3.3.2 Demand Side Management-Water Conservation and Public Participation.......................... 79

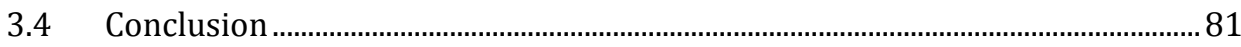




\section{CHAPTER 4}

The Productivity Change in the Privatized Water Sector in China: Technical Change, Efficiency Change and Scale Efficiency Change 1999-

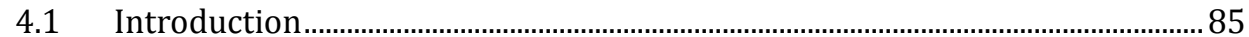

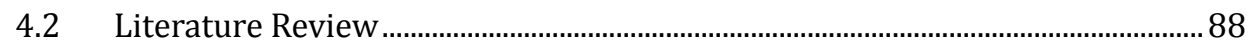

4.2.1 The Theoretical Background of Privatization and Productivity Improvement......................................................................................................... 88

4.2.2 The Mixed Results of Empirical Studies................................................................. 90

4.3 Methodology .....................................................................................................92

4.3.1 The Translog Stochastic Frontier Production Function ……................................. 93

4.3.2 The Parametric Generalized Malmquist Productivity Index (PGMPI)................ 95

4.4 Data............................................................................................................... 97

4.4.1 Specification of the Data................................................................................................... 97

4.4.2 Output Variables.................................................................................................... 98

4.4.3 Input Variables ...........................................................................................................100

4.4.4 Inefficiency Determinants......................................................................................101

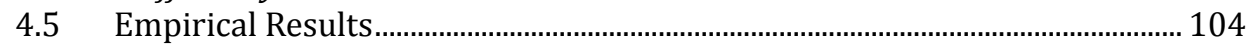

4.6 Conclusion ............................................................................................................. 111

\section{CHAPTER 5}

Environmental concern and water consumption behavior: Multilevel analysis of China.....................................................................................113

5.1 Introduction...................................................................................................... 114

5.2 Literature Review............................................................................................... 115

5.2.1 Environmental Concern...................................................................................................115

5.2.2 Determinants of Environmental Concern ……….......................................................117

5.2.3 Individual-level Social-demographic and Psychological Determinants............117

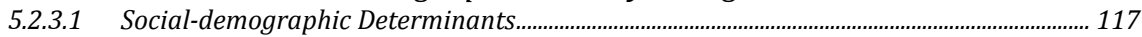

5.2.3.2 Psychological Determinants ........................................................................................................ 119

5.2.4 Group-level Socio-economic Determinants ..............................................................119

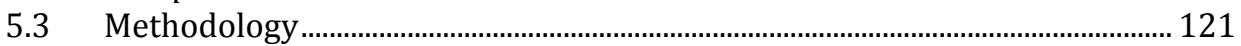

5.3.1 Explanatory Factor Analysis...........................................................................................121

5.3.2 Multilevel Regression Models .......................................................................................122

5.3.2.1 Two-level Linear Regression Model for Continuous Dependent Variables..........................123

5.3.2.2 Two-level Ordered Logistic Regression Model for Ordinal Responses ....................................127

5.3.2.3 Two-level Logistic Regression Model for Dichotomous Responses.........................................129

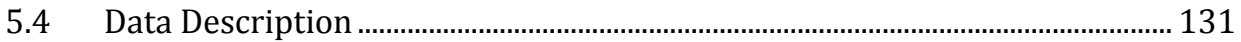

5.4.1 World Value Survey Data (World Value Survey Association)................................131

5.4.2 Other Data ..............................................................................................................133

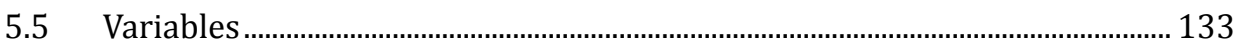

5.5.1 Dependent Variables.......................................................................................................133

5.5.2 Independent Variables ................................................................................................136

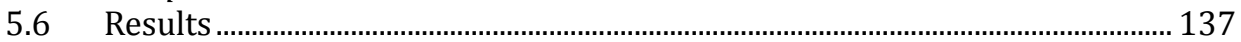

5.6.1 Determinants of Environmental Value.......................................................................138

5.6.2 Determinants of Environmental Attitude …………………….................................146 
5.6.3 Determinants of Environmental Action.

5.6.4 Discussion of the Regional Level Variable GDP per capita and the Quadratic GDP per capita.

5.7 Conclusion and Policy Implications

CHAPTER 6

Conclusion.

6.1 Main Findings

6.2 Policy Implications and Recommendations.

6.3 Limitations and Areas for Future Research 181

Bibliography 184

Appendixes 194

Valorization 212

Curriculum Vitae Jinjin Zhao 216 


\section{Figures}

Figure 1.1: Cubic Water Kuznets Curve

Figure 1.2: The unidirectional relationship of a government and individuals in the urban water management pre-reform

Figure 1.3: The triangular framework of government, businesses and individuals in the urban water management after reform

Figure 2.1: Traditional urban water cycle

Figure 2.2: Efficient urban water management cycle 41

Figure 2.3: Sustainable urban water management framework 42

Figure 2.4: The three stages of Cubic Water Kuznets Curve 50

Figure 2.5: The inflection points of CWKC 54

Figure 5.1: Relationship between environmental concern and the GDP per capita

Figure 5.2: Cubic Water Kuznets Curve and environmental concern-GDP per capita relationship

\section{Tables}

Table 2.1: $\quad$ Definition of variables $\quad 46$

Table 2.2: $\quad$ Summary of variables $\quad 47$

Table 2.3: $\quad$ Correlation matrix $\quad 48$

Table 2.4: Determinants of urban water consumption: Fixed-effects Model 51

Table 3.1: Water prices in Beijing, 1952-1978 (Unit: Yuan/cubic meter) 64

Table 3.2: Water-saving demonstration construction projects in China 80

Table 4.1: $\quad$ The number of observations categorized with ownerships $\quad 98$

Table 4.2: Definitions of the variables 102

Table 4.3: Summary of the variables 103

Table 4.4: The correlation matrix 105

Table 4.5: The translog stochastic frontier production function parameters' estimates 106

Table 4.6: The technical efficiency scores 107

Table 4.7: The technical efficiency score and the Malmquist index decomposition based on ownership 1999-2006

Table 4.8: A Malmquist index decomposition: a summary of the annual mean values of all water firms 1999-2006

Table 4.9: A Malmquist index decomposition: a summary of the annual mean values of state-owned water firms 1999-2006

Table 4.10: A Malmquist index decomposition: a summary of the annual mean values of domestic privately owned water firms 1999-2006

Table 4.11: A Malmquist index decomposition: a summary of the annual mean values of foreign-owned water firms 1999-2006 
Table 4.12: Pairwise correlation coefficients and significances

Table 5.1: Environmental concern indexes of the 1990 WVS

Table 5.2: $\quad$ Environmental concern indexes for the 1995 WVS

Table 5.3: Environmental concern indexes for the 2001 WVS

Table 5.4: Environmental concern indexes for 2007 WVS

Table 5.5: Pairwise correlation of the water conservation behavior variable and environmental concern variables

Table 5.6: Indicators of environmental concern

Table 5.7: Corresponding variable codes for indicators of environmental concern

Table 5.8: Group-level independent variables

Table 5.9: Individual-level independent variables

Table 5.10: 1990 Centered result of environmental value (ordinal variable) 140

Table 5.11: 1995 Centered result of environmental values (ordinal variable) 140

Table 5.12: 2001 Centered result of environmental values (ordinal variable) 142

Table 5.13: 2001 Centered result of environmental values (ordinal variable) 143

Table 5.14: 2007 Centered result of environmental values (ordinal variable) 144

Table 5.15: 1990 Centered result of environmental attitude: willingness to pay (continues variable)

Table 5.16: 1995 Centered result of environmental attitude: willingness to pay (continues variable)

Table 5.17: 1995 Centered result of environmental attitude: willingness to pay (continues variable)

Table 5.18: 2001 Centered result of environmental attitude: willingness to pay (continues variable)

Table 5.19: 2001 Centered result of environmental attitude: willingness to pay (continues variable)

Table 5.20: 2007 Centered result of environmental attitude: willingness to pay (continues variable)

Table 5.21: 1990 Centered result of environmental actions (ordinal variable) 157

Table 5.22: 1995 Centered result of environmental actions (continues variable)

Table 5.23: 2001 Centered result of environmental actions (ordinal variable) 159

Table 5.24: 2001 Centered result of environmental actions (ordinal variable) 159

Table 5.25: 2007 Centered result of environmental actions (dichotomous variable)

Table 5.26: 2007 Centered result of environmental actions (dichotomous variable)

Table 5.27: Centered result of environmental value with quadratic GDP per capita

Table 5.28: Centered result of environmental attitudes (Willingness to pay) with quadratic GDP per capita

Table 5.29: Centered result of environmental action with quadratic GDP per capita 


\section{Abbreviations}

\begin{tabular}{|c|c|}
\hline $\mathrm{ABC}$ & Administration of Building Construction \\
\hline ASM & Administration of Surveying and Mapping \\
\hline AUC & Administration of Urban Construction \\
\hline BMD & Building Materials Department \\
\hline BOD & Biochemical Oxygen Demand \\
\hline BOT & Build-Operate-Transfer \\
\hline CED & Construction Engineering Department \\
\hline CGE & Générale des Eaux \\
\hline $\mathrm{CPA}$ & Construction Planning Agency \\
\hline CPD & Construction Planning Department \\
\hline CPDC & Central Political Department of Construction \\
\hline CWKC & Cubic Water Kuznets Curve \\
\hline EKC & Environmental Kuznets Curve \\
\hline FDI & Foreign Direct Investment \\
\hline GDP & Gross Domestic Products \\
\hline IBT & Increasing Block Tariff \\
\hline MBE & Ministry of Building Construction \\
\hline MBMI & Ministry of Building Materials Industry \\
\hline MEP & Ministry of Environmental Protection \\
\hline MGMR & Ministry of Geology and Mineral Resources \\
\hline MLR & Ministry of Land and Resources \\
\hline MNC & Multinational Corporation \\
\hline MOA & Ministry of Agriculture \\
\hline MOC & Ministry of Construction \\
\hline MOEP & Ministry of Electric Power \\
\hline MOF & Ministry of Finance \\
\hline $\mathrm{MOH}$ & Ministry of Health \\
\hline MOHURD & Ministry of Housing and Urban-Rural Development \\
\hline MURCEP & Ministry of Urban and Rural Construction and Environmental Protection \\
\hline MWR & Ministry of Water Resources \\
\hline MWREP & Ministry of Water Resources and Power \\
\hline NAFTA & North American Free Trade Agreement \\
\hline
\end{tabular}




$\begin{array}{ll}\text { NBL } & \text { National Bureau of Land } \\ \text { NBO } & \text { National Bureau of Oceanography } \\ \text { NBSM } & \text { National Bureau of Surveying and Mapping } \\ \text { NDPC } & \text { National Development Planning Commission } \\ \text { NDRC } & \text { National Development and Reform Commission } \\ \text { NEPA } & \text { National Environmental Protection Agency } \\ \text { NGOs } & \text { Non-Governmental Organizations } \\ \text { OECD } & \text { Organization for Economic Co-operation and Development } \\ \text { PATSTAT } & \text { EPO Worldwide Patent Statistical Database } \\ \text { PGMPI } & \text { Parametric Generalized Malmquist productivity index } \\ \text { PPP } & \text { Public-Private Partnership } \\ \text { SACP } & \text { State Administration for Commodity Prices } \\ \text { SAP } & \text { Administration of Prices } \\ \text { SCD } & \text { State Construction Department } \\ \text { SCLGOEP } & \text { State Council Leading Group Office for Environmental Protection } \\ \text { SCORES } & \text { State Council Office for Restructuring the Economic System } \\ \text { SEC } & \text { Scale Efficiency Change } \\ \text { SETC } & \text { State Economic and Trade Commission } \\ \text { SPC } & \text { State Planning Committee } \\ \text { TC } & \text { Technical Change } \\ \text { TEC } & \text { Technical Efficiency Change } \\ \text { TFP } & \text { Total Factor Productivity } \\ \text { TFPC } & \text { Total Factor Productivity Change } \\ \text { TPB } & \text { Theory of Planned Behavior } \\ \text { UCA } & \text { Urban Construction Agency } \\ \text { UK } & \text { United Kingdom } \\ \text { UNCTAD } & \text { United Nations Conference for Trade and Development } \\ \text { UNESCO } & \text { United Nations Educational, Scientific, and Cultural Organization } \\ \text { US } & \text { United States } \\ \text { WCO } & \text { Water Conservation Office } \\ \text { WMO } & \text { World Meteorological Organization } \\ \text { WVS } & \text { World Value Survey } \\ & \end{array}$




\section{Summary}

Water scarcity is a problem faced by many countries and regions but is particularly acute in urban areas in developing countries, where a safe and secure water supply is threatened by rapid economic development and urbanization, population growth, and the deterioration of the water environment; water shortages in turn restrict socioeconomic development in those developing countries.

In this dissertation, we address two important questions of urban water management: 1) what is the trajectory of urban water consumption and what are the determinants of its formation? and 2) what are the determinants of successful urban water management reform in developing countries and the roles of governments, businesses and individuals?

In Chapter 2, based on the panel data collected in 27 countries from 1960 to 2010, we demonstrate that per capita urban water consumption and per capita GDP have an $\mathrm{N}$ shaped relationship. Following the Environmental Kuznets Curve literature, we denote this relationship the Cubic Water Kuznets Curve (CWKC). We also show that water policies have significant influence on per capita urban water consumption, which implies with proper policy intervention, developing countries can achieve economic development with less water consumption per capita. Among all the countries in our dataset, China has the best performance, namely, the turning points appears at the lowest GDP per capita, which is approximately 1042 US dollars. Therefore, the continuous economic growth in China is accompanied by a rapid increase of water use efficiency in the urban areas. As the largest developing economy, this achievement is worthy of an in-depth study. The urban water management reform in China is reviewed and analysed in this dissertation based on the framework of a triangular interrelated relationship of water actors in which government, businesses and individuals jointly influence the results of the reform.

In Chapter 3, we describe the transformation of institutions, laws, regulations and policies in the reform of urban water management in China. The reform is characterised by the empowerment of local governments regarding financial, administrative and economic issues (decentralisation), the emphasis of market roles (marketisation), the acknowledgement of individual economic activities (privatisation), and the involvement of the public (public participation) to establish integrated sustainable urban water management. Two important policies, privatization policies and public participation policies are reviewed in details.

In conjunction with the international trend of privatization in the 1990s, the Chinese water sector has experienced privatization reforms since the mid-1990s. In Chapter 4, we examine the productivity change of China's water sector at the initial stage of its privatization reforms. Our work provides further evidence for the debate on the effects of privatization in water sectors by estimating a translog 
stochastic frontier production function and a Parametric Generalized Malmquist productivity index. Overall, we find that the Chinese water sector was aided by the privatization reforms and the participation of multinational water firms during 1999-2006, which occurred under strong government intervention and guidance.

At individual level, the environmental concern and environmental behavior of citizens are crucial for solving environmental problems and maintaining the sustainable development of a society. Thus, it is important to understand citizens' environmental concern and its determining factors at different levels. In Chapter 5, we use a multilevel analysis to investigate environmental concern and water consumption behavior in the Chinese urban areas for the period 1990-2007. We examine the determinants of environmental concern at an individual level by controlling provincial/regional level factors. By bridging environmental concern and water conservation behavior, our findings also provide useful information on the impact factors of citizens' water conservation behavior. 


\section{Samenvatting}

Waterschaarste is een probleem waar vele landen en regio's mee kampen, maar is bijzonder acuut in stedelijke gebieden in ontwikkelingslanden, waar een veilige watervoorziening wordt bedreigd door de snelle economische ontwikkeling en verstedelijking, bevolkingsgroei, en de verslechtering van het watermilieu; watertekorten op hun beurt beperken sociaal-economische ontwikkeling in die ontwikkelingslanden.

In dit proefschrift richten we ons op twee belangrijke vragen van het stedelijk waterbeheer: 1) Wat is het traject van stedelijk waterverbruik en wat zijn de determinanten van zijn vorming? en 2) wat zijn de determinanten van de succesvol hervorming van stedelijk waterbeheer in ontwikkelingslanden en de rol van overheden, bedrijven en particulieren?

In hoofdstuk 2, gebaseerd op de panelgegevens in 27 landen, verzameld van 1960 tot 2010, tonen we aan dat stedelijk waterverbruik per hoofd van de bevolking en het BBP per hoofd van de bevolking een $\mathrm{N}$-vormige relatie hebben. Naar aanleiding van de literatuur over de Kuznetscurve met betrekking tot het milieu, duiden we deze relatie aan met de 'Cubic Water Kuznets Curve' (CWKC). We tonen ook aan dat het waterbeleid grote invloed heeft op het stedelijk waterverbruik per hoofd van de bevolking, wat impliceert dat met het juiste interventiebeleid, ontwikkelingslanden economische ontwikkeling kunnen realiseren met minder waterverbruik per hoofd van de bevolking. Van alle landen in onze dataset, heeft China de beste prestaties, te weten, de keerpunten verschijnen op het laagste BBP per hoofd van de bevolking, dat is ongeveer \$1042. Daarom gaat de voortdurende economische groei in China gepaard met een snelle toename van de efficiëntie van watergebruik in de stedelijke gebieden. Als de grootste ontwikkelende economie, verdient deze prestatie een diepgaande studie. De stedelijke hervorming van waterbeheer in China wordt beoordeeld en geanalyseerd in dit proefschrift op basis van het kader van een driehoekige samenhangende relatie van wateracteurs waarin overheid, bedrijven en particulieren gezamenlijk invloed hebben op de resultaten van de hervorming.

In hoofdstuk 3 beschrijven we de transformatie van instellingen, wet- en regelgeving en beleid bij de hervorming van het stedelijk waterbeheer in China. De hervorming wordt gekenmerkt door de bekrachtiging van de lokale overheden met betrekking tot de financiële, administratieve en economische vraagstukken (decentralisatie), de nadruk van marktrollen (vermarkting), de erkenning van individuele economische activiteiten (privatisering), en de betrokkenheid van het publiek (inspraak) om geïntegreerd duurzaam stedelijk waterbeheer vast te stellen. Twee belangrijke beleidsterreinen, privatisering en beleidsinspraak, worden in detail beoordeeld. 
In combinatie met de internationale trend van privatisering in de jaren 1990, heeft de Chinese watersector privatiseringshervormingen ondergaan sinds het midden van de jaren 1990. In hoofdstuk 4 onderzoeken we de productiviteitsverandering van de Chinese watersector in de eerste fase van de privatiseringshervormingen. Ons werk levert verder bewijs voor het debat over de gevolgen van de privatisering in watersectoren door het schatten van een translog stochastische pioniersproductiefunctie en een parametrische Generalized Malmquist productiviteitsindex. Over het algemeen vinden we dat de Chinese watersector werd geholpen door de privatiseringshervormingen en de deelname van multinationale waterbedrijven in 1999-2006, wat gebeurde onder sterke interventie en begeleiding van de overheid.

Op individueel niveau, is de bezorgdheid over het milieu en milieu-gedrag van de burgers van cruciaal belang voor het oplossen van milieuproblemen en het handhaven van de duurzame ontwikkeling van een samenleving. Het is dus belangrijk om de milieuoverwegingen van burgers en haar bepalende factoren op verschillende niveaus te begrijpen. In hoofdstuk 5 maken we gebruik van een meerlagige analyse om bezorgdheid over het milieu en waterconsumptiegedrag in de Chinese stedelijke gebieden voor de periode 1990-2007 te onderzoeken. We onderzoeken de determinanten van bezorgdheid over het milieu op individueel niveau door het controleren van provinciale/regionale niveaufactoren. Door het overbruggen van bezorgdheid over het milieu en het gedrag van het behoud van water, bieden onze bevindingen ook nuttige informatie over de impactfactoren van waterbesparingsgedrag van burgers. 
CHAPTER 1

\section{Introduction}





\section{$1.1 \quad$ Research Background}

Water is the origin and core of life, and it is one of the most widespread elements on our planet. Historically, water gestates and nourishes human civilisations. Humans used to take water for granted; however, today, water scarcity affects every continent, and water has become one of the most precious resources on the earth. Currently, approximately 700 million people in 43 countries suffer from water scarcity (UNESCO, 2012). Unfortunately, the number is still growing. Under the existing climate change scenario, almost half of the world's population will be living in area of high water stress by 2030 (UNESCO, 2009). In many places, water scarcity is threatening social and economic development; in some extreme cases, the scarcity is seriously affecting peoples' health and lives.

Water scarcity is defined as "the point at which the aggregate impact of all users impinges on the supply or quality of water under prevailing institutional arrangements to the extent that the demand by all sectors, including the environment, can not be satisfied fully". This is partly caused by the natural, uneven geographic and temporal distribution of water resources and partly caused by human activities. In many places, economic growth, population expansion, and environmental degradation lead to a rapid increase in water demands and sharp reduction of available water resources. Between 1900 and 1995, water consumption throughout the world increased by a factor of six, which is more than double the rate of the population growth (WMO, 1998). Meanwhile, the amount of water is effectively reduced by pollution and contamination. Therefore, water scarcity is both a natural and a human-caused phenomenon.

The tension between supply and demand, to a great extent, the water allocation issue challenge water management in many countries, especially in the urban areas of the developing world. In those places, the need of water for economic development and the necessity of environmental protection pose a severe challenge to the government. Moreover, rapid urbanisation, population expansion and environmental deterioration further increase the difficulty of urban water management in the developing world. Hence, satisfying the water demands of different users with high quality services while maintaining sustainable development and utilisation of water resources is the core target of urban water management in developing countries.

Traditionally, approaches to meeting water needs in urban areas have focused on the design and construction of water supply systems, ranging from dams, aqueducts and wells to water treatment and distribution facilities. However, since the mid-1970s, finding and utilising new sources of water necessary to satisfy urban areas' growing water demands have become more difficult and expensive and have greatly challenged the traditional methods of water management and seriously threatened its further development. Therefore, innovative water management is urgently required to tackle this problem. 
Sustainable urban water management is advocated as the solution to the failure of traditional urban water management and water problems in urban areas; it aims to efficiently and effectively manage freshwater, wastewater, and storm water simultaneously. Under the sustainable urban water management framework, the goal of urban water management is to establish a non-harmful artificial water cycle in an urban area in which water resources are efficiently and effectively used; no pollutant will be produced and discharged back into the natural water sources (Eisengberg and Reed, 2003; Braungart et al., 2007; McDonough and Braungart, 2010). Compared with developed countries, developing nations face more challenges in realising sustainable urban water management due to the rapid increase in the water demand, lagging technologies, backward management, low productivity, low efficiency, and water pollution and contamination.

Therefore, we expect that developing countries will follow developed nations' path to achieve sustainable urban water management. Therefore, long-term effort is needed, and a continuously rising trend of water consumption will be observed in the urban areas of developing countries. Surprisingly, when we examine the international trend of urban water consumption, we observe a stabilised or even declining trend of water consumption in some developing countries. This trend is even more obvious when per capita water consumption is measured. This result suggests that developing countries could develop their own approach to sustainable urban water management, instead of copying the polluted way of economic development that developed countries experienced in the 1970s.

Our study shows that the water consumption trend in urban areas is not a monotonically increasing curve; instead it is an $\mathrm{N}$-shaped curve that has two turning points and eventual stabilized (Figure 1.1). This N-shaped relationship between per capita urban water consumption and per capita GDP is similar to the cubic form of the Environmental Kuznets Curve proposed by Grossman and Krueger (1991 and 1995); therefore, we name it the Cubic Water Kuznets Curve (CWKC).

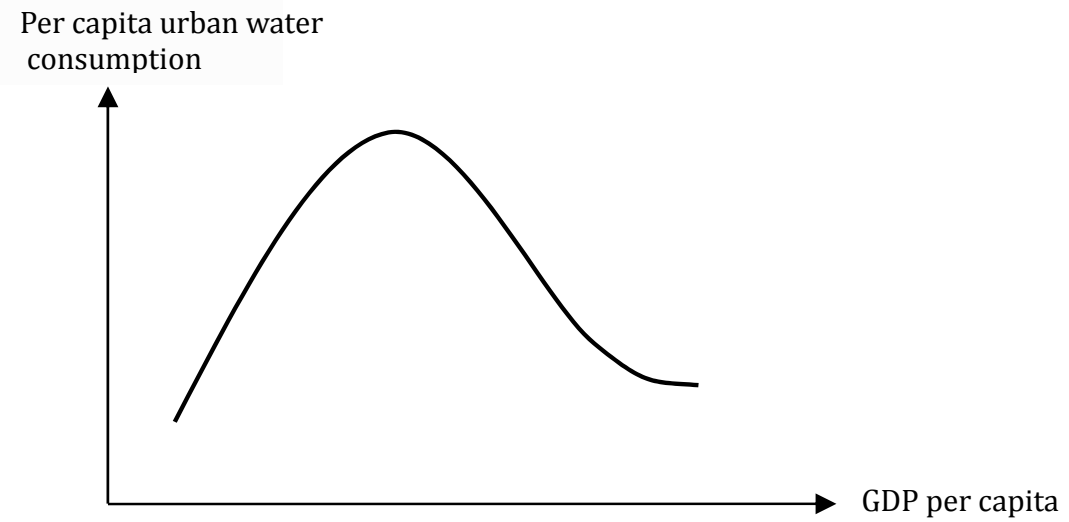

Figure 1.1: Cubic Water Kuznets Curve 
One of the most important findings in this study is the earlier appearance of the inflection point of the CWKCs for all the developing countries in our dataset. Specifically, it shows that the three developing countries in our sample data (Mexico, Turkey and China) achieve a decline of urban water consumption per capita with a much lower GDP per capita compared with the developed countries in the dataset. These results are desirable, as the earlier presence of the turning point with a lower GDP per capita implies less water consumption and fewer negative environmental impacts for the same economic achievement. Among all the countries in our dataset, China has the best performance, namely, the turning points appears at the lowest GDP per capita, which is approximately 1042 US dollars. Therefore, the continuous economic growth in China is accompanied by a rapid increase of water use efficiency in the urban areas. As the largest developing economy, this achievement is worthy of an in-depth study.

As many other developing countries, China carried out a series of neo-liberalist reforms in water sector since early 1990s. This is largely affected by the international trend of neo-liberalist reform in the public sector, which was initiated by the Thatcher administration in UK. In 1989, the Conservative Party led by Margaret Thatcher privatised the British water industry, which marks the initiative of neoliberalist reforms in the water sector worldwide. The adoption of neo-liberalist policies in water sector aims at solving the problem of heavy financial burdens on the government, the lagging technologies, the backward management, the low productivity and low efficiency in the state-managed urban water systems. Public failures, the lack of incentives and self-interest are blamed for those problems.

Internationally, neo-liberalist water reform became prevalent in the South in the beginning of the 1990s and was advocated by international organisations such as the World Bank. In many developing countries, neo-liberalist reforms lead to the deregulation, marketisation, privatisation and opening-up of the water sector. Multinational water corporations were actively involved in the water reforms in developing countries. It is believed that they had abundant funds, advanced technologies and rich management experience, which were missing in the water sector in South.

However, after two decades of trials, neo-liberalist water reforms have failed to achieve the desired goals in many developing countries, such as the well-known cases in Bolivia, Malaysia and Venezuela. The rapid increase in water bills, failed connection goals and unsolved leakages led to massive opposition movements in those countries. Meanwhile, unstable exchange rates and the difficulty of reaching expected profit rates reduced the foreign water corporations' confidences in those markets. The absence of corresponding water institution and regulation reforms, the lack of negotiation and management competences, and the shortage of transparent information communication also contribute to the failure of neo-liberalismoriented water reforms.

The neo-liberalist water reforms were largely based on the idea of water as an economic good, which should be priced at its economic value such that the market 
will ensure its allocation to the best users. However, water is a resource vital to life with no substitute. Hence, it is fundamentally different from other economic goods. If one needs energy, for example, one could choose between fossil fuel, nuclear power, solar, wind, etc. The market mechanism works almost naturally for such types of goods. With water, however, that is not the case. One cannot easily choose another type of water without tapping the same resource. Moreover, some water uses have high societal relevance but with limited ability to pay, particularly water uses for environmental, social and cultural requirements. Hence, water is not a purely economic good but also a public good, which should not be left completely to the market. Governments generally make decisions on the basis of political considerations with strong considerations of social, cultural, and sometimes environmental interests.

The mixed characteristics of economic good and public good of water require integrated water management, i.e., joint efforts made by governments, businesses and water users, by which the public failures and market failures could mutually be corrected and overcome. Hence, we argue that the role of government is crucial to the success of water reforms and the implementation of sustainable urban water management. The change of a government's role from water sector manager and operator to a regulatory agency would effectively reduce the public failure in urban water management. Under the new framework, the government will be responsible for regulating different actors and stimulating their positive potentials in urban water management. In fact, the neo-liberalist water reforms in the UK and France are accompanied by the adjustment of water administrations and the heavy implementations of water policies and regulations.

Those adjustments and changes are even more crucial to the success of urban water management reform in the developing world. Developing countries need to expand their water services system to fulfil the rapid increase of water demands and improve the quality of services; however, they also need to address the incomplete water legal system, the incorrect water pricing system, the missing property rights system, the lack of management experience, and the absent monitoring system.

The simple adoption of neo-liberalist water reform from the developed world, without adjusting it to the local situations in the developing world, led to the failure of urban water reform in many developing countries. This is largely due to the market failures caused by ignoring the necessity of timely adjustments of water institutions and water legal systems and overlooking the importance of government intervention. By the end of the 1990s, there was massive withdrawal of multinational water corporations from developing countries' water markets, mainly from Latin America, South Asia and Africa. The majority of those projects and plants were returned to the public.

In contrast, we have witnessed a boom of the Chinese water sector and the active involvement of multinational corporations in the Chinese water market since the end of the 1990s. As the largest developing economy, China initiated its water 
management reform in 1979. Like other developing nations, the water management reform in China is also characterised with neo-liberalist policy adoption. However, the reform is being carried out slowly and under strong policy interventions. The government attaches great importance to the water institution and water legal system construction, the water market and property rights system establishment, and the supervision system formation.

In this thesis, we closely scrutinise the urban water management reform in China by mainly focusing on the government transitions and relative policy designs and implementations. Our work could help the Chinese water authorities better review the reform results and evaluate their policies by learning from the past and further improving urban water management. Furthermore, our work provides valuable information on the policy designs and implementations of Chinese water management reform and could be useful to the water authorities in other developing countries. Our work also reflects that the successful management of public goods with market-oriented reform required strong government, which could provide proper policy intervention and sector supervision.

\subsection{Structure and Contributions}

In this thesis, we first reveal the long-term relationship between per capita urban water consumption and economic development. Based on panel data collected in 27 countries from 1960-2010, we show that per capita urban water consumption and per capita GDP have an N-shaped relationship. Furthermore, we prove the significant positive effects of policies on per capita urban water consumption. Hence, we argue that with proper policy intervention, developing countries could achieve the same economic objectives with less water consumption per capita. This finding is valuable for developing countries as many are facing rapid increases of water demands and serious water shortages in urban areas.

As the largest developing economy, China's performance of urban water consumption is outstanding. In the past 15 years, the country successfully stabilised the total urban water consumption, despite its fast economic development, population expansion and urbanisation. Undoubtedly, this great achievement is closely linked with the urban water management reforms carried out in China over the past three decades. Therefore, a comprehensive review and analysis of the Chinese urban water management reform is meaningful and valuable.

In China, the reform of urban water management is characterised by the empowerment of local governments regarding financial, administrative and economic issues (decentralisation), the emphasis of market roles (marketisation), the acknowledgement of individual economic activities (privatisation), and the involvement of the public (public participation) to establish integrated sustainable urban water management. The water institution is restructured, and the water legal system is established. More power is assigned to local governments. Under the decentralised system, the central government guides and regulates urban 
water management through a series of policy documents, laws and regulations, while the local governments and municipalities are responsible for water management in their jurisdictions by developing specific regulations and implementation measures, which greatly facilitates the production and efficiency improvement of urban water management.

Regarding the supply aspect, the establishment of a water market, the construction of a property rights system, and the reform of the water pricing system in the water sector brought vitality to the urban water sector. In China, the privatisation of the water sector is characterised by the cooperation between foreign private sectors and Sino water firms, either owned by the public or by the private sectors. The participation of the foreign private sector in the urban water sector in China contributes to sector performance improvement by introducing abundant funds, advanced technologies and management, and competition.

Regarding the demand aspect, public participation policies are adopted with the aim of increasing the public's environmental awareness and environmental friendly behaviour, namely, water-saving awareness and water-saving behaviour. Participation in decision making on water related issues, general school education and environmental information disclosure through media and NGOs are the main channels to disseminate water-related information and involve the public in water affairs. However, implementing public participation takes a long time and requires the continuous, long-term effort of the government.

Under the new framework of urban water management, the government adjusts its role from manger and operator to regulator and supervisor. Instead, the newly emerged domestic private sector and the restructured autonomous state-owned water firms become the main providers of water services. Water users are also given more responsibilities and duties in the new urban water management system. The traditional unidirectional relationship between the government and individuals in urban water management before the reform (Figure 1.1) is replaced by the newly constructed triangular interrelated relationship (Figure 1.2) among the government, businesses and individuals.

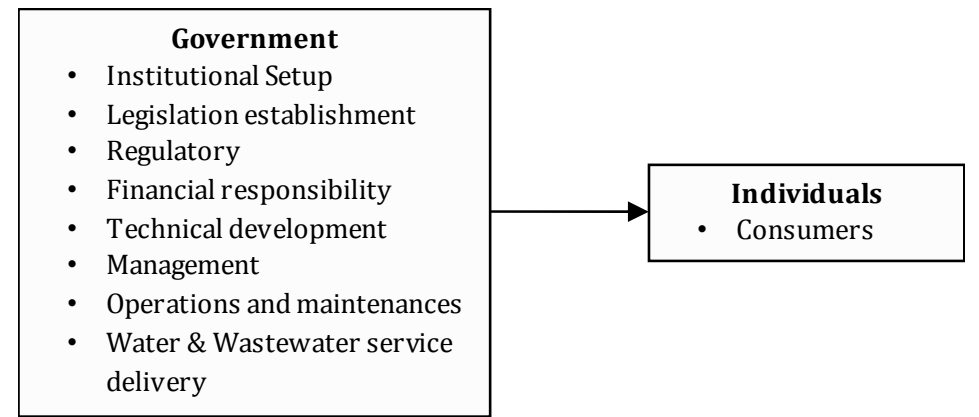

Figure 1.2: The unidirectional relationship of a government and individuals in the urban water management pre-reform 
Under the new urban water management post-reform, the government, businesses and individuals are interrelated and interacting. Together, their interactions and behaviours jointly determine the performance of the urban water management in China. In this thesis, our analysis is organized based on this triangular interrelated relationship. We investigate the Chinese urban water management reforms based on the changes and evolutions of each actor in this relationship.

In Chapter 2, we investigate the general urban water consumption trends and the outstanding performance of developing countries, especially China. Based on panel data collected in 27 countries from 1960-2010, we find an N-shaped relationship between per capita urban water consumption and per capita GDP, which we name as the Cubic Water Kuznets Curve (CWKC). Following the EKC literature, we further decompose the GDP per capita in the CWKC to the scale factor, economic composition factor, technological change factor and policy factor (Grossman and Krueger, 1991; Shafik, 1994). Policy effects on per capita urban water consumption are the focus of our study. Two types of water policies are distinguished in our study: efficiency water policies and effectiveness water policies. An efficiency policy aims to improve water use efficiency in a country, while the effectiveness policy seeks to diminish the negative effects of urban water consumption on nature, such as pollution. The results show that the efficiency water policy variable is negatively correlated with per capita urban water consumption, statistically significant at the $1 \%$ level. The effectiveness water policy and per capita urban water consumption have an inverted U-shaped relationship, which implies that governments should make continuous, long-term efforts to obtain positive outcomes for per capita water consumption in urban areas.

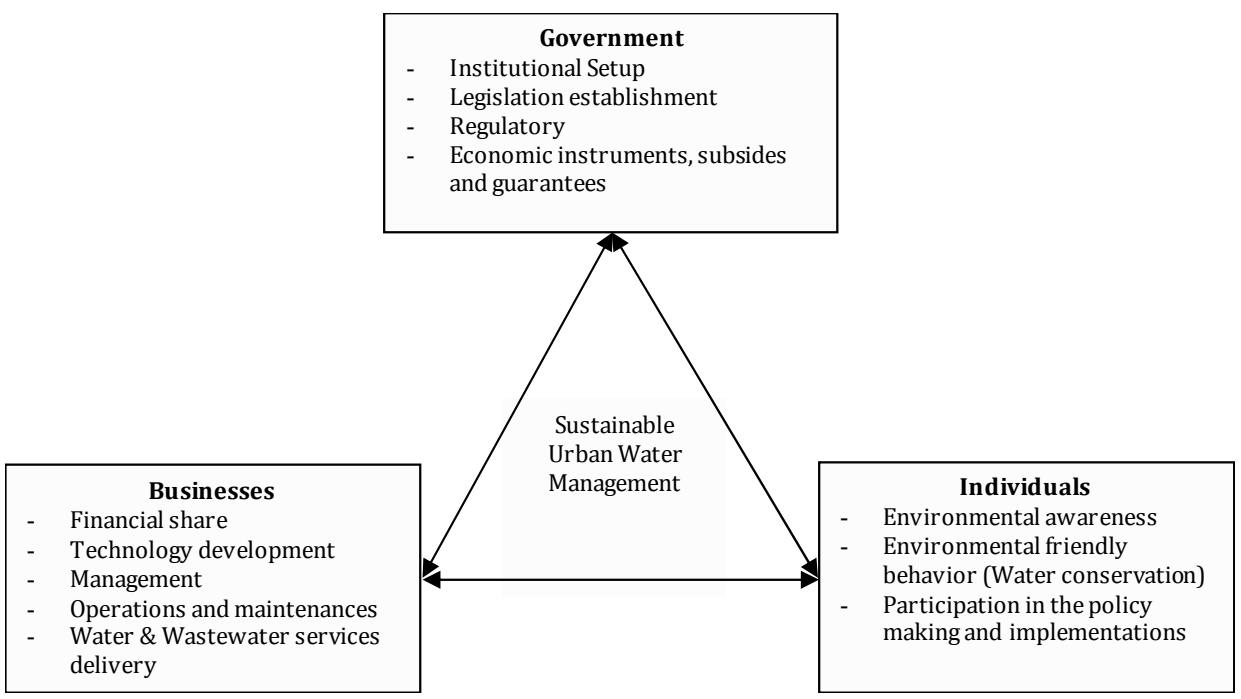

Figure 1.3: The triangular framework of government, businesses and individuals in the urban water management after reform 
Chapter 2 contributes to the literature of the Environmental Kuznets Curve in two ways: 1) it broadens the literature of the Environmental Kuznets Curve by studying water as a natural resource and studying urban water consumption patterns and 2) it investigates policy effects concerning the formation of the Cubic Water Kuznets Curve in the context of developing countries.

In the Chapter 3, we focus on the governmental roles and performances in the urban water management reform. This chapter provides a comprehensive analysis of the evolution of water institutions, the establishment of water laws and regulations, and the design and implementation of water policies during the reform of urban water management. Based on the supply-demand management framework, we further discuss two of the most important policy designs and implementations in the urban water management reform in China, namely, the privatisation policies and public participation policies. The strong presence of government policy intervention greatly contributes to the boom of the urban water sector and the improvement of urban water management. Our work contributes to the literature as it is the first comprehensive analysis that demonstrates how changes in institutions, policies, laws and regulations contribute to the development of urban water management in China.

In Chapter 4, we mainly investigate the performance of businesses in the urban water management reform. We examine the effects of privatisation policies on the water sector in China based on firm-level panel data from 1999-2006. By applying a translog stochastic frontier production function, we identify the production frontier of the water sector and examine its productivity change during the privatisation reforms. The technical change, technical efficiency change and scale change are examined by decomposing the Parametric Generalised Malmquist Productivity Index. Furthermore, the ownership discrepancy is identified based on the group mean values of the productivity growth and decomposition factors. The empirical results show that water sector privatisation reforms accompanied by significant policy interventions in China have had positive influences on the water sector. The timely adjusted policies contribute to the active participation of the foreign private sector in the Chinese water sector, the fast growth of domestic privately owned water firms and the successful reform of state-owned water firms.

The productivity of the entire sector were increased in the observation period, which was mainly achieved through technical change. The massive investments in the water sector during 1999-2006 caused a negative value of the scale efficiency change due to the diseconomies-of-scale character of the water sector. The technical efficiency change was mainly positive in the observation period.

The effect of ownership on productivity is further examined. The foreign-owned water firms forms the sector's frontier and had the highest technical efficiency scores and technical change rates in the observation period. The state-owned water firms have the lowest technical efficiency scores, however, their productivity was improved over time, but only to a small extent. This finding may be due to their substantial accumulation of obsolete equipment, excess employees and backward 
management practices. Without these heavy burdens, domestic privately owned water firms could easily embrace the newest technology directly, which led to the high technical efficiency scores. Most likely, the inferior performance of domestic privately water firms, compared with their foreign competitors, is caused by managerial differences. Management knowledge is tacit knowledge that takes time to learn and transfer. The technical efficiency change was positive for state-owned water firms and negative for both domestic privately owned water firms and foreign-owned water firms. The negative value of technical efficiency change of foreign owned water firms might be caused by the changes of ownership in the observation period. Regarding the domestic privately owned water firms, there might be two reasons accounting for their negative technical efficiency change. The first reason is related to their sunk cost. The second reason is derived from Saal and Parker (2000)'s study in which they observed that the British firms which made efforts to boost their technical change can simultaneously suffered from negative technical efficiency change.

Our study in the Chapter 4 potentially contributes to the empirical literature on productivity, as it shows that privatisation reform could contribute to efficiency achievements in the water sector of developing countries. However, this feat relies on proper government intervention and guidance. The degree to which the policy interventions can influence the privatisation reforms largely depends on the central and local governments' competence and capacity. Moreover, this is the first study that quantitatively investigates the privatisation reforms of the Chinese water sector at the firm level.

The environmental concern and environmental behaviour of citizens are crucial for solving environmental problems and maintaining the sustainable development of a society. Thus, it is important to understand citizens' environmental concern and determining factors at different levels. In Chapter 5, we use a multilevel analysis to investigate the effects of public participation policies in the fields of environmental management and water management, namely, the environmental concern and water consumption behaviour changes in Chinese urban areas during 1990-2007. We examine the determinants of the environmental concern (environmental value, environmental attitude and environmental action) at an individual level by controlling provincial/regional level factors. By bridging environmental concern and water conservation behaviour, our findings also provide useful information on the impact factors of citizens' water conservation behaviour. In general, we find improved environmental concern and water conservation behaviour in China during the study period; this partly reflects the success of the public participation policy implementation. Moreover, the individuals' environmental concern and water conservation behaviour are strongly linked to their economic status, which includes education level, employment status, age and gender. The formation of the public's environmental concern is also affected by the development status of their local environment, such as their city or province. By identifying the impact factors of environmental concern and water conservation behaviour, our study provides valuable information to the Chinese water authorities for future policy design and implementation. Our study contributes to the environmental literature as it 
quantitatively examines the determinants of environmental concern at both the individual and group levels in China. 


\section{CHAPTER 2}

\section{The Cubic Water Kuznets Curve: \\ The Determinants of Urban Water Consumption}





\section{$2.1 \quad$ Introduction}

Water, the most widespread element on our planet, today, has become a restrictive factor of socioeconomic development in many areas, especially in developing countries. The industrial revolutions, population explosion and the improvement in the quality of life over the past two centuries dramatically changed water consumption patterns around the world. Between 1900 and 1995, water consumption throughout the world has increased by a factor of six, more than double the rate of population growth. This increase of water consumption in urban areas is even more dramatic due to urbanization over the past decades.

Urban population survive on water that is either brought from hundreds or even thousands of miles away using an elaborate water infrastructure or that has been extracted locally from ground water. Traditionally, approaches to meeting water needs have focused on the design and construction of water supply systems, ranging from dams, aqueducts and wells to water treatment and distribution facilities. Up until the 1970s, water was regarded abundant and inexpensive (Durante et al., 2011) and thus no efforts were devoted to its conservation. Water was then underpriced, and no externality was concerned. Over the past three decades, however, the traditional water management approach has been strongly challenged by the continually rising demand for water and the serious deterioration of the water environment. Water is no longer cheap and plentiful but has become a costly and scare resource. Therefore, innovative water management is urgently required to tackle this new challenge.

Studies in water consumption showed that economic activity is the primary determinant of global water consumption (Vorosmarty et al., 2000). There existed a long-term positive correlation between water use and economic growth in some regions (Hoehn and Adanu, 2008). However, in the early 1980s, water consumption in both Europe and North America peaked and then decreased, despite the continuous economic expansion there (International Hydrological Programme, 2005). This phenomenon is even more apparent when per capita water use is measured (Gleick, 2003). Thus, it would be interesting to closely examine the relationship between per capita water consumption and economic growth, especially in the context of urbanization and developing world, which has rarely been investigated.

To fill the gap of the literature, we research the relationship between per capita urban water consumption and per capita GDP based on a long-period panel data collected in the 26 Organization for Economic Co-operation and Development (OECD) countries and China from 1960-2010. We find an N-shaped relationship and identify three stages in the relationship. At the first stage, per capita urban water consumption increases following economic development, then reaches a peak consumption volume. In the second stage, water consumption per capita decreases despite continuously increasing GDP per capita. In the third stage, when economic development reaches a very high level, water consumption per capita stabilizes or start to increase slightly. As this $\mathrm{N}$-shaped relationship is similar to the 
Cubic form of the Environmental Kuznets Curve (EKC) proposed by Grossman and Krueger $(1991,1995)$, we propose the Cubic Water Kuznets Curve (CWKC) to describe this urban water consumption pattern.

Following the EKC literature, we further attribute the urban water consumption per capita in CWKC to the economic scale and structure, technological change and policy factors (Grossman and Krueger, 1991; Shafik, 1994). Because we are primarily interested in policy effects on the evolution of CWKC, we further define two groups of policies, namely, indirect water policies and direct water policies. Indirect water policies denote a group of policies aiming at socioeconomic goals other than better water management but nonetheless influencing water consumption, such as the policies to promote development of manufacturing or service sector. Direct water policies are designed and implemented with the motivation of efficient and effective water management. The results of econometric analyses show that policy variables and per capita urban water consumption have an inverted-U relationship, which implies that governments should make continuous and long-term efforts to obtain positive effects on water saving in urban areas. The peak value of CWKC and the corresponding GDP per capita value are strongly affected by the policies, no matter whether they are direct or indirect. For some countries, stabilization or a slightly increase in per capita of urban water consumption can be observed when their GDP per capita reaches a high level, which may be caused by the change of household sizes and economic structure (proportion of agriculture, manufacturing and services sectors in the economy).

China was chosen in this study because its rapid economic development over the past three decades provides an interesting case. Analyzing the data on China alone, we observe the change of urban water consumption along a country's development course, as China started from a low-income level to become a middle-income nation. The massive policy interventions in water management over the last few decades also make China a unique case for policy study. Theoretically, our methodology is generally applicable to any country if water consumption data are available. Moreover, the existence of CWKC in China, Mexico and Turkey, reflected by our data, provides valuable implication that with proper, long-term and consistent policy interventions, developing countries are able to achieve the same economic growth with lower per capita water consumption in urban area than the developed countries did in the past.

Our study contributes to the literature in the following aspects: first of all, it broadens the literature of EKC by studying water as a natural resource and urban water consumption patterns; second, it investigates policy effects on the formation of the CWKC in the context of development; third, it collects and analyze a longperiod panel data in comparison to many existent literature that often use crosssectional and short-period panel data. Arguably different country should have different Water Kuznets Curves due to their diversified economic scale and structure, technological change and policy factors. It is problematic to use only cross-sectional data to research the formation of Water Kuznets Curve. In this case, there is only one curve constructed based on the observations from various 
countries at the same point of time. In contrast, based on panel data we are able to construct a curve for each country to provide accurate account of formation of Water Kuznets Curve along their development course; fourth, most of the existent studies focused on either domestic water use or industrial water use or treated them separately in one paper. However, in reality domestic water use and industrial water use are closely linked and even interdependent. They compose urban water use. The quantity of available water is fixed at a point in time in a region or area such that one unit of increased consumption in one sector will automatically reduce the water availability in the remaining sectors. In developing countries, this phenomenon is even more prominent, as industries are mainly concentrated in urban and semi-urban areas. Given the intrinsic relationship between urbanization, economic growth and water use, it is logical and proper to analyze urban water use as a whole, instead of focusing domestic and ind

ustrial water use separately.

The remainder of the chapter is organized as follows: In Section 2, we review the previous studies on the topics of EKC, Water Kuznets Curve and its determinants. In Section 3, we first prove the existence of CWKC and then further investigate the factors contributing to the formation of the CWKC. Section 4 concludes.

\section{$2.2 \quad$ Literature Review}

\subsubsection{Environmental Kuznets Curves and Water Consumption}

The Environmental Kuznets Curve (EKC) describes the relationship between various indicators of environmental quality and income per capita as an inverted-U shape curve. The theory states that at earlier stages of development, economic growth will lead to environmental degradation and the depletion of natural resources, but beyond some level of per capita income, depending on the indicators, the trend reverses itself so that a high income level of economic growth will lead to environmental improvement. The EKC was first introduced by Grossman and Krueger in their work on the potential environmental impacts of NAFTA (1991) and popularized by the World Bank reports (Shafik and Bandyopadhyay, 1992; World Bank, 1992). The most common explanation for the inverted-U shaped EKC is that the demand for good environmental quality begins to increase when a country achieves a sufficiently high standard of living; from then the willingness to pay for a clean environment rises by a greater proportion than income (Selden and Song, 1994; Baldwin, 1995; Roca, 2003).

Economic growth affects environmental quality through three different channels: scale, composition and technique effects (Grossman and Krueger, 1991). Scale effects capture the idea that as an economy expands, resource use increases with additional economic growth. Composition effects refer to the relative size of different economic sectors within an economy, which affect resource use because resource intensity varies across sectors. Technique effects refer to the different technologies that have different impacts on the environment. GDP is a direct 
measurement of an economy's overall scale. Composition is viewed as related to national income, as lower income economies are likely to produce different goods than high income economies. Technological improvements are viewed as responding to factor prices and, more generally, to regulation. At the low income levels, economic development is mainly achieved through the expansion of economy, namely, the scale of economies. The economic structure is primarily focused on agriculture and gradually shifts to manufacturing. The production technology is relatively backward and polluting. As a result of a combination of all of these factors, pollution increases. However, after the economy further develops, technological change effects can overtake scale and economic composition effects and lead to the reduction of pollution (Heerink, et al. 2001).

The majority of the EKC literature examines environmental quality as a function of income. Pollution levels are the most common indicator of environmental quality used in these studies. Empirical studies suggest that the EKC relationship is more likely to hold with short-term, local impact and human health environmental indicators, such as sulfur dioxide, Biochemical Oxygen Demand (BOD) and so on, but not with the long-term global indicators, such as carbon dioxide and other greenhouse gases (Arrow et al., 1995; Barbier, 1997; Cole et al., 1997; Selden and Song, 1994; Harbaugh et al., 2002). Some studies, including the original paper of Grossman and Krueger (1991), used a cubic form of EKC and find an N-shaped relationship, which they called the Cubic EKC (e.g., List and Gallet, 1999; Stern, 2004). The positive correlation between environmental indicators and cubic GDP implies that environmental indicators will stabilize or fluctuate at small range when income reaches a very high level.

The fact that the majority of the EKC literature focus on pollution indicators has led to criticism that the entire literature to some extent ignores the component of environmental quality represented by natural resources (Arrow et al, 1995). Among the limited studies that have examined natural resource use, the majority focus on deforestation (Shafik and Bandyopadhyay, 1992; Panayotou, 1993; Cropper and Griffiths, 1994; Koop and Tole, 1999; Ehrhardt-Martinez et al., 2002, Culas, 2007; etc.), and few address other types of resource use, such as energy, pesticides and water (e.g., Suri and Champman, 1998; Managi, 2006; Cole, 2004).

\subsubsection{Water Kuznets Curve}

Building primarily on the EKC literature, only a handful studies have examined how water use correlates with national income (Rock, 1998/2000; Gleick, 2003; Cole, 2004; Jia et al., 2005; Yoo, 2007; Duarte et al., 2013). Based on cross-sectional data of US national water withdrawals and panel data of US state water consumption, Rock (1998) found per capita water withdrawal and water consumption in the US follows an inverted-U shaped path which is consistent with the EKC hypothesis. In another study, Rock (2000) further argued that the water use intensity in an economy is closely related to its natural water endowment, the economic structure and government policies. Gleick (2003) found a similar inverted-U shaped relation- 
ship between per capita water consumption and income in the US and Finland. He further argued that efficient and effective water management is a useful tool to level off or decrease water consumption. Cole (2004) used estimated water consumption data for five continents in 1900,1940,1950,1960,1970, 1980, 1990 and 1995 to test the EKC hypothesis. His results also supported the existence of an inverted-U shaped relationship between water consumption and income. Based on the industrial water data collected by the World Resources Institute for the years 1995, 1998, 1999, 2000, 2001 and 2002, Jia et al. (2006) showed that industrial water uses in most OECD countries followed the EKC. By examining the UNESCO data from 65 countries for the years 1960, 1970, 1980, 1990, 1995, 2000 and 2008, Duarte et al. (2013) claimed that the EKC hypothesis is proved and the countries facing water scarcity tend to be more efficient in using water. They also argued that good institution could contribute to environmental improvement, thus leading to less water consumption per capita.

In the very few studies on the developing countries, the EKC was hardly proved (Gleick, 2003; Cole, 2004). This may be due to the reason that unlike developed countries, developing countries are still in the early stage of their development. Even if the EKC does exist, it may yet be observed because the developing countries are still on the left side of the EKC, far from reaching the turning point. In addition, many developing countries have already begun their efforts on environmental protection, moving from command-and-control policies to implement marketoriented forms of regulation (Dinda, 2004). Therefore, it is questionable whether developing countries will follow the same EKC trajectory of the developed countries. They can improve or have improved their EKC path based on a better understanding of the relationship between environmental quality and income.

\subsubsection{The Determinants of Water Kuznets Curve}

Scholars have argued that the factors other than income also contribute to the decrease of pollution and resource consumption (Ng and Wang, 1993; Horvath, 1994; Antle and Heidebrink, 1995; Baldwin, 1995; Hettige et al., 1996). Economic structure, i.e., the composition of the economy by agriculture, manufacturing and services sectors, is such a factor. The change of economic structure affects water consumption by changing the portfolios of water-using activities. The cases of Germany (German Federal Statistical Agency, 1996), Japan (Infrastructure Development Institute, 1997) and the US (Solley et al., 1998) demonstrate that as the economy of a country develops, the sector accounting for the largest share of the GDP will shift from agriculture, to manufacturing and last to services sector. Along this structural change, water consumption per capita will increase first with the growth of national income, but eventually stabilizes or decreases when national income reaches a high level.

Unlike structural change, technological change always leads to improvements in the efficiency of water use, which in turn leads to decrease in water consumption per capita. Carr et al. (1990) showed that technological changes were likely to be 
the cause of the drop in water consumption intensity by average $2.2 \%$ per annum in the US manufacturing sector between the 1950s and 1980s.

Because scholars have long argued that policy intervention is the dominant factor in explaining the decline in pollution after the GDP per capita of a country reaches the level of middle-income countries, efforts have been made to incorporate policy factors in the test of the EKC (Dasgupta et al., 2002; Andreoni and Levinson, 2001; Chavas, 2004). Panayotou (1997) used index of contract enforcement and bureaucratic efficiency as proxies to test the EKC hypothesis. He found that the effectiveness of policies and institutions can significantly reduce environmental degradation at low income levels and speed up improvements at higher income levels. De Bruyn (1997) also found that environmental policy plays an important role in EKC formation. By investigating the water quality-income relationship, Hettige et al. (2000) revealed that stricter environmental regulations made a significant contribution to improving water quality. Similarly, Magnani (2001) questioned the automatic formation of EKC along with GDP growth, and argued that EKC will be more likely to emerge wherever and whenever there is public support for environmental protections, such as regulation and policy. Echoing these arguments, Yandle et al. (2004) contended that better policies will cause the race to the bottom of EKC to end sooner, and environmental improvements to come about at lower income levels.

Demographic characteristics of individual countries affect the environmental quality-income relationship as well (Shafik, 1994; Yandle et al., 2002). Population growth and urbanization are the main driving forces behind the increase of domestic water use in cities. Moreover, population growth augments the demand for other consumer goods that indirectly causes increases in industrial water use. Household size also influences water demand. Some water consumption in household such as water use for cleaning or gardening is almost a fixed quantity regardless of the number of residents in a house. Therefore, in an aging society as the average household size decreases, average per capita water use within household may increase (Birrell et al., 2005). It is noteworthy that though population factors strongly affect domestic water use, the income effect is still the dominant factor and is estimated to be five to eleven times stronger than the population effect on water withdrawals (Alcamo et al., 2007).

The physiographic factors, which include hydrological difference between regions and climate change, are another important determinant of water consumption (Adeloye et al., 1999). Scientific evidence has been presented that climate change will alter rainfall patterns such that when it rains it will rain more heavily, but the periods without rain will grow longer. Therefore, climate change will lead to decline in the availability of water resources at the basic level on average, but with a high deviation among different months. Moreover, climate change also affects urban water use. On the one hand, high temperature and less precipitation will automatically lead to an increase in water use (Gato et al., 2007). On the other hand, industrial water use is expected to rise with temperature, as the cooling 
process and other heat sensitive industries will need more water as production input.

\subsubsection{Urban Water Management and Water Policies}

Different types of direct water and wastewater policies were designed and adopted in different periods, which reflects different understandings of good and sustainable urban water management over time. The historical route towards sustainable urban water management evolved from pollution control with end-of-pipe solutions to efficiency management before finally shifting to the more recent sustainable urban water management.

Pollution control with end-of-pipe aims at protecting water resources by removing already formed contaminants from a stream of water, which was implemented from the early 1960s through the 1970s. Starting in the late 1980s, efficiency management became the key strategy of urban water management and was lauded as a "win-win" solution that minimized water consumption and wastewater discharge. It was initially proposed during the Earth Summit in Rio de Janeiro and promoted by the Business Council (now the World Business Council). Efficiency means "doing more with less" through its famous three Rs: reduce, reuse and recycle. In the context of urban water management, it encompasses the following concepts: reducing water intake, increasing water productivity, reducing pollution in the wastewater, and increasing wastewater recycling (Harremoës, 1997; Xia, 2010). Over the last decade, sustainable urban water management has become dominant and has been adopted in many countries. Water-cycle management conceptualizes of the urban water cycle as an artificial sub-cycle of the natural water cycle; therefore, ideally, this sub-cycle should have no negative impacts on the natural water cycle (Berger and Finkbeiner, 2010). First, the quantity of water withdrawal should not change the whole water environment of the natural water body. Second, all the elements added to the urban water cycle stream should be removed before the stream goes back to the natural water body, which generally means zero emissions. As a result, sustainable urban water management not only emphasizes the efficiency of water use but also highlights the importance of effectively managing the whole system (Barbiroli, 2006).

Traditionally, there is a tendency among analysts and planners to treat water and wastewater separately because they are often administered by separate agencies. This leads to the separate design and implementation of water and wastewater policies, which overlooks the economic and natural linkages between water and wastewater. As a result, some policies were poorly designed, and the efficiency and effectiveness of both sides' policies were weakened or even eliminated. In fact, both intake water supply and wastewater disposal require generate costs and effect water ecology. Moreover, the increasing wastewater reduces water availability and damages the environment. Thus, water and wastewater are strongly interdependent, and together, they form the water system cycle in urban areas. The joint design and implementation of water and wastewater policies under the concept of the 
sustainable urban water management system is highly important and necessary, and there is no doubt that the problem will be tackled only if it has been clearly understood (Hellström et al., 2000; Coombes and Kuczera, 2002; Mitchell, 2002).

Under the sustainable urban water management concept, the goal of urban water management is to establish a non-harmful artificial water cycle in an urban area, in which no pollutant will be produced and discharged back into natural water sources (Eisengberg and Reed, 2003; Braungart et al., 2007; McDonough and Braungart, 2010). The urban water system can thus be viewed as a dual production process that connects two halves. The first half is the clean water production process, in which clean water as a raw material is taken from natural bodies of water bodies, either rivers, groundwater or salt water from the ocean; cleaned by the water supply plant; and then delivered to customers, either households, industries or for public use. The second half is the wastewater treatment service process, when used water from different clean water clients is collected and delivered to the wastewater treatment plant as raw material; after disposal, it will be discharged back into the natural water bodies.

As shown in figure 2.1, the traditional urban water cycle can be viewed as an artificial sub-cycle of the natural water cycle, where clean water is taken from a natural body of water, used for human activities and then returned to nature, sometimes after being purified. Because natural bodies of water have a certain capacity to self-purify, artificial sub-cycles of urban water should not affect the water cycle when the pollutant discharge level is low enough that the body of water can self-purify. As a result, the natural water cycle can maintain its own balance.

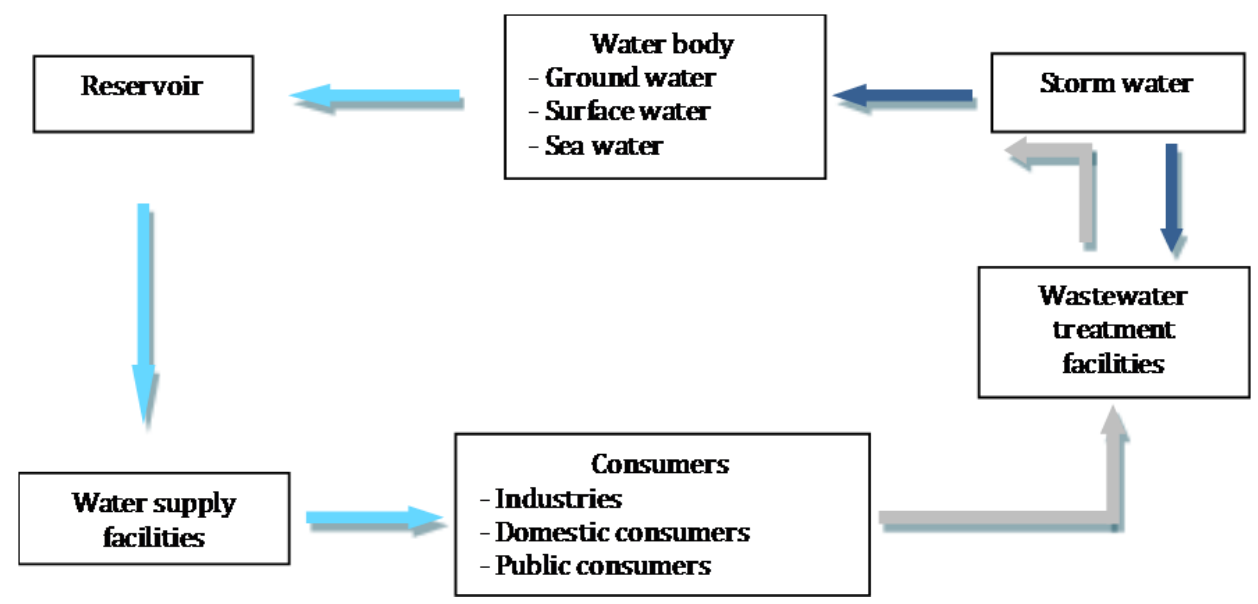

Figure 2.1: Traditional urban water cycle

After the Industrial Revolution, however, the artificial urban sub-cycle dramatically expanded, with more clean water withdrawal and substantial inflow of toxic materials, which greatly exceeded the water system's natural recovery capability, leading to the deterioration of natural water bodies and the surrounding ecosys- 
tems. In this case, the urban water cycle is similar to a linear, one-way production process that keeps producing waste and toxic materials that are sent to nature, leading to the accumulation of waste and the degradation of the water system, which also caused a health crisis for human, plant and animal populations. Therefore, we observe a continuous deterioration of the urban environment associated with traditional urban water systems.

Efficient urban water management was proposed as the solution to this problem. Under this framework, water is used highly efficiently and storm water is brought in as a new water supply in the system. Shower and kitchen water can be used for toilet flushing or urban gardening. With proper controls, treated wastewater can also be reused for toilet flushing, gardening and industrial processes. If geographic distance is allowed, it could also be used for agricultural irrigation. The efficient urban water management cycle is showed in figure 2.2.

Notably, efficient urban water management focuses on the quantity perspective of water use and is viewed as an isolated system, disconnected from the larger natural water cycle and therefore although it already alleviates the conflict over water in urban areas, it will not change the story. Efficient urban water management only slows the pollution rate; it does not solve the problem. Therefore, a qualitative approach should be proposed and simultaneously adopted in urban water management.

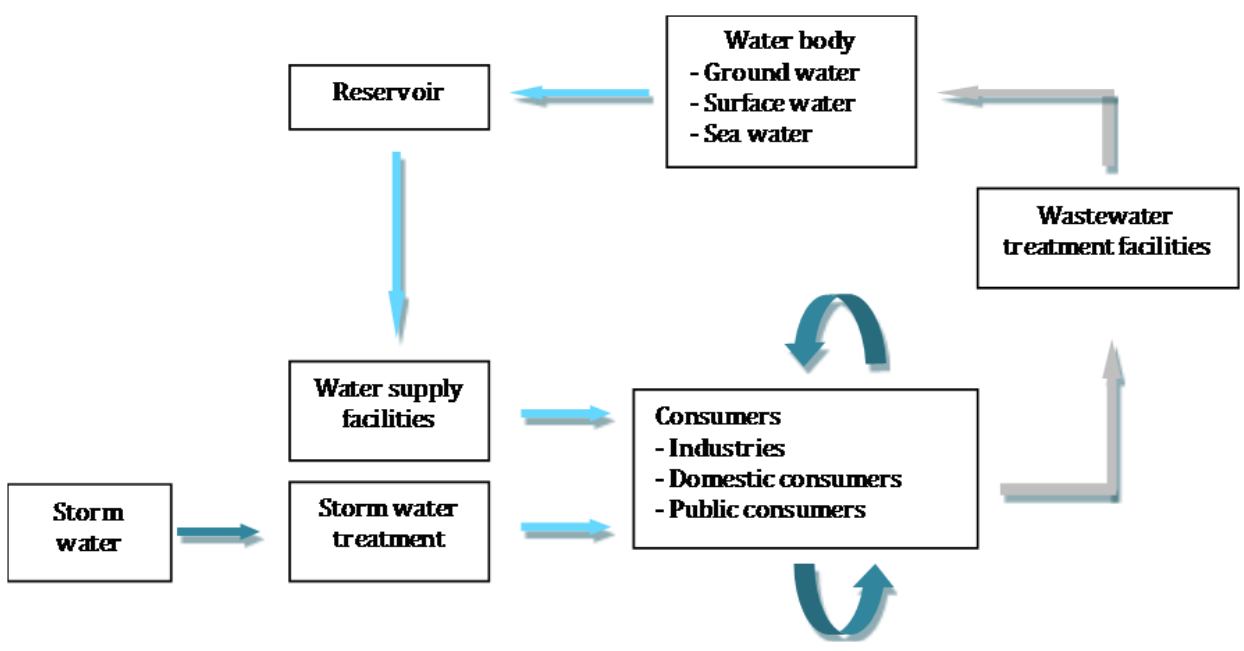

Figure 2.2: Efficient urban water management cycle

The sustainable urban water management approach is to target the problems in the efficient urban water management system. A new cycle, the nutrients cycle, is identified, in addition to the three Rs (reduce, reuse, recycle). The nutrients cycle is the cycle of all the artificial added materials to the water intake stream. In other words, all those materials should be recycled completely after use. As a result, all the nutrient cycle materials will leave wastewater stream after treatment, and the 
water disposal from wastewater treatment plants will be as clean as or even cleaner than withdrawal water. To achieve this, in addition to the efforts stemming from the efficient urban water management approach, life cycle management of the nutrients cycle as it is related to the urban water cycle is also required, which further increases the effectiveness of urban water management(Freire et al., 2001; Leeuw, 2005; Mulhall and Braungart, 2010). Quality control should be adopted such that limited toxins enter the water cycle and the nutrients from wastewater are saved and used to generate energy and fertilize soil. Nutrients are taken up into plants from the soil. Those plants are harvested and some of the nutrients are shipped to cities, where they are eaten, and eventually end up in city wastewater systems. A varying but significant percentage of the nutrients end up nourishing water bodies while only a small fraction are returned to the soil from whence they came. While enormous investment in fertilizer is needed to replace the lost nutrients in the soil, other investments are required to address the water issue. Therefore, the sustainable urban water management system requires the regeneration of nutrients that it then sends into the biological production cycle (Cole, 2012). Metals and other minerals can be recycled and used as nutrients in other production cycles or can at least be processed such that they do no harm to the environment (Lundin, 1999). This cannot be achieved simply by focusing on the urban water system, however: it requires the cooperation of industries and citizens (Fuijita and Hill, 2007; Orecchini, 2007).

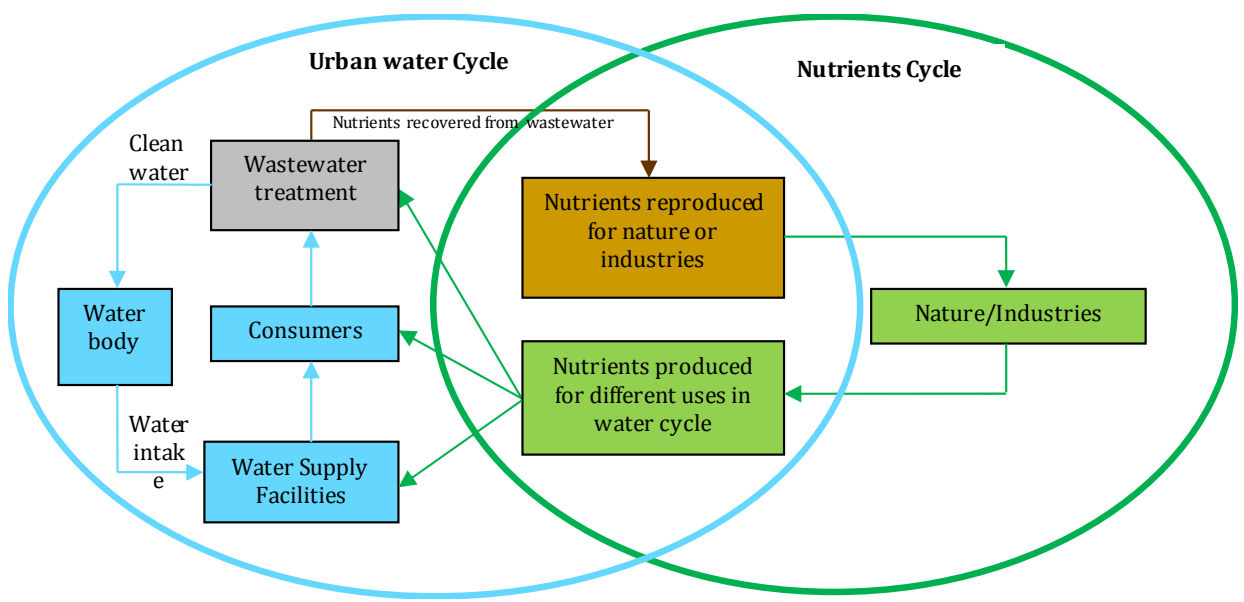

Figure 2.3: Sustainable urban water management framework

Based on the sustainable urban water management concept, different water and wastewater policy variables are selected to represent efficiency and effectiveness policies, which as a whole could explain the policy effects on urban water consumption pattern. Ideally, well designed policies will lead to the optimization of the Cubic Water Kuznets Curve parameters, namely, the country can achieve same level of economic development with less water consumption per capita. 
In summary, our research contributes to the EKC literature from the following perspectives: 1) it fills the data gap in the EKC literature; 2) it extends the EKC literature by studying urban water consumption patterns ${ }^{1}$; 3 ) it provides a deeper understanding of urban water use patterns in the developing world; and 4) it improves our understanding and knowledge of sustainable urban water management.

\section{$2.3 \quad$ Empirical Analysis}

In this research, we propose two models of urban water consumption to test the CWKC hypothesis. The first model follows the conventional Kuznets curve approach and uses a quadratic and cubic function of GDP to capture the combined effect of economic development on urban water consumption. The second model further investigates the relationship between per capita urban water consumption and the socioeconomic, demographic, climate and policy factors. Our focus is to explore the effect of policy on water consumption in urban area.

\subsubsection{The Cubic Water Kuznets Curve}

The first panel data model we adopt is as below

$\mathrm{W}_{\mathrm{it}}=\beta_{1}+\beta_{2} \mathrm{GDPC}_{\mathrm{it}}+\beta_{3} \mathrm{GDPC}_{\mathrm{it}}^{2}+\beta_{4} \mathrm{GDPC}_{\mathrm{it}}^{3}+\mu_{\mathrm{it}}$

where $W_{i t}$ is per capita urban water consumption of the country $i$ in the year $t$, $G D P C_{i t}$ is the GDP per capita, GDPC $C_{i t}^{2}$ is the quadratic of GDP per capita and $G D P C_{i t}^{3}$ is the cubic of GDP per capita. We aim to test whether there is an N shaped relationship between per capita urban water consumption and GDP per capita, i.e. the existence of CWKC. Similar to the EKC, the CWKC is the combined result of economic scale and structure, technological improvement, and policy intervention. These factors are aggregated and represented in the model (1) by a function of GDP per capita. All the factors which cannot be captured by GDP per capita are controlled for by the year dummy.

\subsubsection{The Cubic Water Kuznets Curve Regression to Test Policy Effects}

The second model further investigates the relationship between per capita urban water consumption and the disaggregated socioeconomic, demographic, physiographic and policy factors.

\footnotetext{
1 The definition of urban area differs from country to country; however, it is generally defined either by the population density of a certain area or an area where the population density is higher than a certain level in a particular politically-defined area. In my research, the urban area population is abstracted from the World Bank database, in which urban population is the midyear population of areas defined as urban in each country and reported to the United Nations. Therefore, the variable in my sample could well reflect the urbanization condition of each country.
} 
$\mathrm{W}_{\mathrm{it}}=$

$\beta_{1}+\beta_{2}$ GDPC $_{i t}+\beta_{3}$ Fixed Capital Formation ${ }_{i t}+$

$\beta_{4}$ Secondary and Tiertary Industries $_{\text {it }}+\beta_{5}$ Inward FDI $_{\text {it }}+\beta_{6}$ Triadic Patents $_{i t}+$

$+\beta_{7}$ Household Size $_{i t}+\beta_{8}$ Mean Temperature $_{i t}+\beta_{9}$ Total Precipitation $_{\text {it }}+$

$\beta_{10}$ Policy $_{i t}+\mu_{i t}$

where $W_{i t}$ is per capita urban water consumption of the country $i$ in the year $t$, Fixed Capital Formation it $_{\text {refers }}$ to the fixed capital formation per capita, representing the economic scale of the country. Secondary and Tiertary Industrie$s_{i t}$ is the share of the GDP from the secondary and tertiary industries in total GDP, representing the structure of the economy. Inward FDI $I_{i t}$ measures the inward foreign direct investment per capita, which represents openness of the economy and effects of learning from other countries. Triadic Patents $s_{i t}$ denotes the technological development level by the number of the triadic patent families (Perman and Stern, 2003; Lantz and Feng, 2006; Popp, 2005 and 2010). A triadic patent family is a group of patents applied for in Europe, Japan and the US to protect the same invention. Triadic patents are of substantial innovative value because first of all international patent applications are typically more costly than domestic ones (van Pottelsberghe and Mejer, 2010); secondly, patents applied for in the three regions cover wide geographic scope, spanning the most advanced and technologically sophisticated countries of the world. This variable is thus used by the governmental agency such as the National Science Foundation of the US and the intergovernmental organizations such as Eurostat and OECD as an indicator to measure the innovativeness of a country or a region. Household Size ${ }_{i t}$ measures the average household size of country $i$ over time. Mean Temperature $e_{i t}$ and Total Precipitation $i t$ are two climate factors controlled for in the regression. Year dummy variables are also included to control for other time-variant factors.

Because the central research question is whether water policies implemented by governments have impact on per capita urban water consumption, i.e., the formation of the CWKC, the variables represented by Policy $y_{i t}$ are the key variables of the model. We classify the water policies affecting the CWKC into two types: indirect and direct water policy. Before the 1990s, the formation of CWKC in most developed countries was a self-motivated process without any purposive intervention from governments. However, per capita urban water consumption might be indeed influenced by the government policies which primarily aimed at stimulating technology diffusion and promoting the development of secondary and tertiary industries, but had side effects on water consumption. We defined these policies as indirect water policy.

We are more interested in the direct water policies which the governments in the developed countries started to implement in the late 1980s and early 1990s, after the policy makers there recognized the potential benefits of policy intervention in water conservation. These water policies can be further classified into two categories: efficiency and effectiveness policies. The efficiency policies aim at improving water use efficiency and achieving higher output by consuming less water in a 
country, without emphasizing management of the water cycle system and wastewater treatment. In contrast, the effectiveness policies seek to better manage the whole urban water cycle system, minimizing the impact of human activities on natural water system, but without highlighting the goal of saving water.

We introduce four variables to represent these two types of policies. We use Water Productivity ${ }_{i t}$ which is defined as GDP from the secondary and tertiary industries divided by urban water consumption volume as a proxy for water efficiency policy. We propose three proxies to represent water effectiveness policy: Wastewater Treatment Rate $e_{i,}$ Sludge Recycled Rate Rit $_{\text {Public Pollution Control }}$ Expenditure on Water and Wastewater $i$. All three variables measure policy effects on water management, which can potentially affect water consumption patterns in urban areas. In theory, when the wastewater treatment rate and sludge recycling rate approach one, the urban water system is becoming zero-emission and environmental friendly. Similarly, the higher the public expenditures on water and wastewater management, the lower the per capita water consumption in urban areas. The definitions of all the variables and the statistic description are presented in Table 2.1 and Table 2.2, respectively. Table 2.3 shows that their correlation is at a modest level. 
Table 2.1: Definition of variables

\begin{tabular}{|c|c|}
\hline Variable name & Definition and note \\
\hline \multicolumn{2}{|c|}{ CWKC Regression (unit of analysis: 27 countries) } \\
\hline Per capita urban water consumption & $\begin{array}{l}\text { Logarithm of the quantity of water consumed by per capita } \\
\text { urban population }\end{array}$ \\
\hline GDP per capita & Logarithm of gross domestic product per capita \\
\hline Quadratic GDP per capita & $\begin{array}{l}\text { Quadratic of the logarithm of gross domestic product per } \\
\text { capita }\end{array}$ \\
\hline Cubic GDP per capita & Cubic of the logarithm of gross domestic product per capita \\
\hline \multicolumn{2}{|c|}{ CWKC Policy Effects Regression (unit of analysis: 27 countries) } \\
\hline Fixed capital formation & Logarithm of fixed capital formation per capita \\
\hline Secondary and tertiary industries & $\begin{array}{l}\text { Logarithm of share of the GDP from the secondary and } \\
\text { tertiary industries in total GDP }\end{array}$ \\
\hline Inward FDI & Logarithm of the inward foreign direct investment per capita \\
\hline Triadic patents & Logarithm of number of triadic patent families \\
\hline Household size & Logarithm of the average number of people in a household \\
\hline Mean temperature & Logarithm of annual mean temperature \\
\hline Total precipitation & Logarithm of total annual precipitation \\
\hline Water productivity & $\begin{array}{l}\text { Logarithm of GDP from the secondary and tertiary industries } \\
\text { divided by urban water consumption volume }\end{array}$ \\
\hline Wastewater treatment rate & Logarithm of the wastewater treatment rate in urban areas \\
\hline Quadratic wastewater treatment rate & $\begin{array}{l}\text { Quadratic of the logarithm of the wastewater treatment rate } \\
\text { in urban areas }\end{array}$ \\
\hline Sludge recycled rate & $\begin{array}{l}\text { Logarithm of the sludge recycling rate of waste water } \\
\text { treatment plants }\end{array}$ \\
\hline Quadratic sludge recycled rate & $\begin{array}{l}\text { Quadratic of the logarithm of the sludge recycling rate of } \\
\text { waste water treatment plants }\end{array}$ \\
\hline $\begin{array}{l}\text { Public pollution control expenditure on } \\
\text { water and wastewater }\end{array}$ & $\begin{array}{l}\text { Logarithm of public pollution control expenditure on water } \\
\text { and wastewater per capita }\end{array}$ \\
\hline $\begin{array}{l}\text { Quadratic public pollution control } \\
\text { expenditure on water and wastewater }\end{array}$ & $\begin{array}{l}\text { Quadratic of the logarithm of public pollution control } \\
\text { expenditure on water and wastewater per capita }\end{array}$ \\
\hline Year dummy & $\begin{array}{l}\text { The base group is } 1960 \text { for model (1)-(3) in Table } 4,1970 \text { for } \\
\text { model (4), and } 1990 \text { for model (5). }\end{array}$ \\
\hline
\end{tabular}


Table 2.2: Summary of variables

\begin{tabular}{lccccc}
\hline Variable & $\begin{array}{c}\text { Number of } \\
\text { observations }\end{array}$ & Mean & $\begin{array}{c}\text { Standard } \\
\text { Deviation }\end{array}$ & Minimum & Maximum \\
\hline Per capita urban water consumption & 526 & 5.90 & 0.45 & 4.24 & 6.81 \\
GDP per capita & 1364 & 8.87 & 1.48 & 3.76 & 11.68 \\
Quadratic GDP per capita & 1364 & 80.90 & 24.64 & 14.12 & 136.43 \\
Cubic GDP per capita & 1364 & 753.91 & 319.57 & 53.08 & 1593.53 \\
Fixed capital formation & 1267 & 7.55 & 1.33 & 2.40 & 10.11 \\
Secondary and tertiary industries & 1166 & 4.52 & 0.11 & 3.78 & 4.61 \\
Inward FDI & 1012 & 4.60 & 2.16 & -9.39 & 11.13 \\
Triadic patents & 903 & 5.01 & 2.40 & 0.00 & 9.94 \\
Household size & 694 & 1.08 & 0.22 & 0.67 & 1.75 \\
Mean temperature & 1102 & 2.20 & 0.60 & -1.20 & 3.13 \\
Total precipitation & 1137 & 6.78 & 0.34 & 5.80 & 7.72 \\
Water productivity & 510 & 4.64 & 1.23 & 0.80 & 6.95 \\
Wastewater treatment rate & 317 & 3.85 & 0.90 & 0.26 & 4.60 \\
Quadratic wastewater treatment rate & 317 & 15.65 & 5.66 & 0.07 & 21.12 \\
Sludge recycled rate & 196 & 4.24 & 0.50 & 0.87 & 4.60 \\
Quadratic sludge recycled rate & 196 & 18.21 & 3.52 & 0.75 & 21.19 \\
Public pollution control expenditure on & 399 & 3.69 & 1.29 & -0.08 & 6.32 \\
water and wastewater & 399 & 15.30 & 9.06 & 0.01 & 39.93 \\
Quadratic public pollution control & & & & & \\
expenditure on water and wastewater & & & & & \\
\hline
\end{tabular}




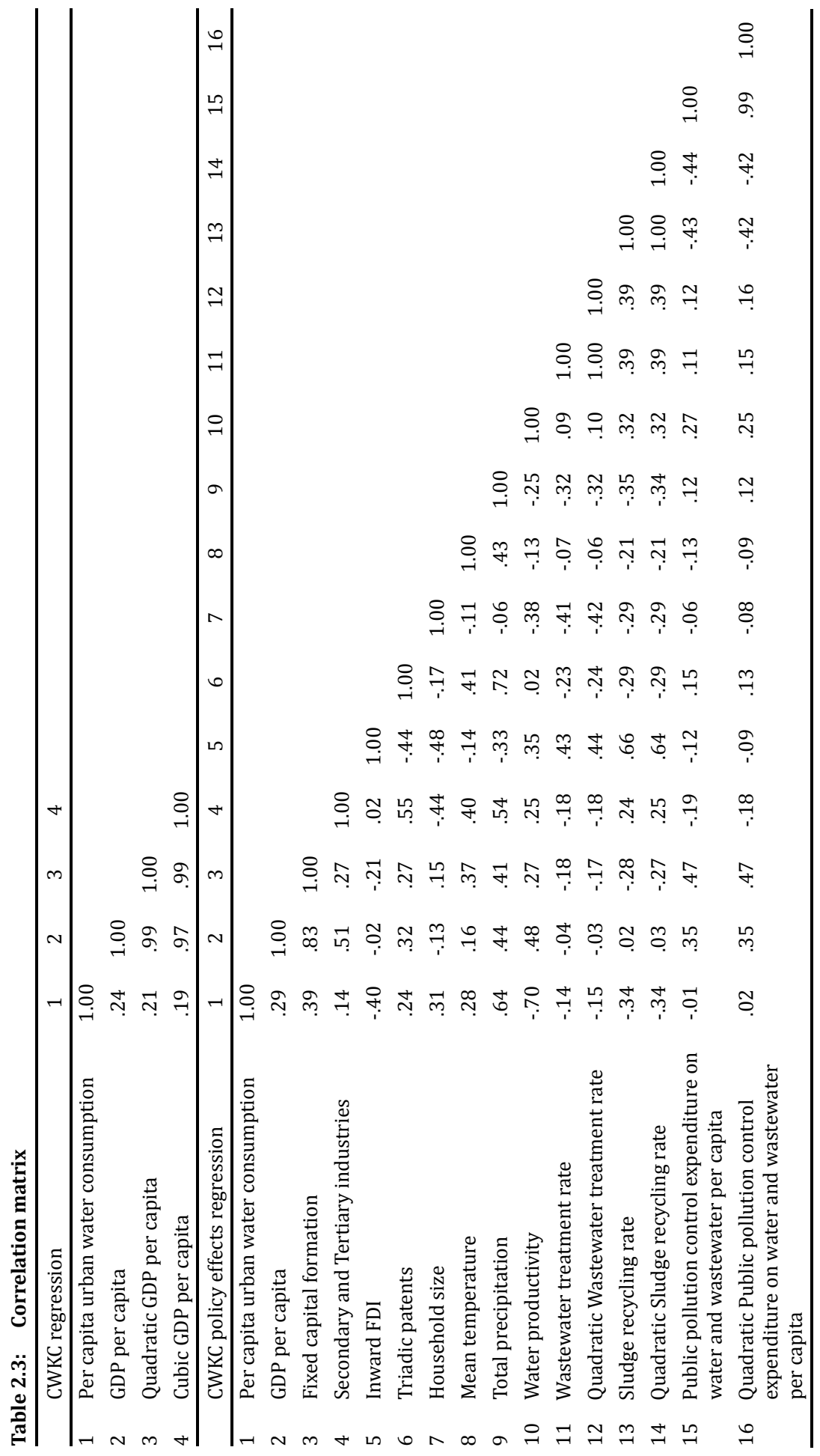




\subsubsection{Data}

We analyze a panel of data covering 26 OECD countries and China for the period from 1960 to 2010. We choose the 26 OECD member states but exclude the rest eight mainly because of the data availability. ${ }^{2}$ For the same reason, we are not able to include more developing countries into this study. The data of GDP, GDP per capita and fixed capital formation are obtained from the World Bank database. The data of population, urban population and inward FDI are attained from the United Nations Conference for Trade and Development (UNCTAD) database. The data of secondary and tertiary industries are abstracted from the OECD database. The triadic patent family data are obtained from the PATSTAT database constructed by the European Patent Office. We use the public water supply data to measure the water consumption in urban areas of each individual country, because urban water is supplied by public water plants and distribution systems. Most of the data on urban water consumption are obtained from local authorities of each individual country, except that only a part of them are extracted from the Eurostat database. Temperature and precipitation data are provided by the meteorological authorities in each individual country. The data of household size and policy variables are provided by the different countries' local statistical bureaus, ministry of the environment, water firms and the Eurostat.

\subsubsection{Results}

We run the model (1) and (2) with fixed-effects and random-effects panel data model. The random-effects model assumes that the random effects (individual specific unobservables) are uncorrelated with the explanatory variables (individual specific observables). We have sufficient reason to suspect this assumption in our case. For example, the volume of per capita urban water consumption is affected by the environmental awareness of the urban citizens in the countries, which is not measured by the explanatory variables (we cannot find consistent and long time period data on environmental awareness of the urban citizens) and is accordingly captured by the random effects. However, these random effects (e.g., the environmental awareness of the urban citizens) would be correlated with the GDP per capita, which is one of the explanatory variables. If the assumption is violated as such, the random-effects estimator is not consistent. We perform the Hausman test to verify this assumption. The random-effects model is rejected in all the specifications, though the results are still presented in Table A in Appendix A. The results from the fixed-effects model with heteroskedasticity controlled for are provided in Table 2.4.

\footnotetext{
2 The 26 OECD countries included in this study are Australia, Austria, Belgium, Canada, Denmark, Finland, France, Germany, Greece, Iceland, Ireland, Italy, Japan, Korea, Luxemburg, Mexico, The Netherlands, Norway, New Zealand, Portugal, Spain, Sweden, Switzerland, Turkey, The United Kingdom, and The United States. The OECD countries excluded from this study include Czech Republic, Hungary, Poland, Slovakia, Chile, Slovenia, Estonia and Israel.
} 
In support of the CWKC hypothesis, the coefficient of the GDP variable is positive and statistically significant at the $1 \%$ level. The coefficient of the quadratic GDP variable is negative and statistically significant at the $5 \%$ level, and the coefficient of the cubic GDP variable is positive and statistically significant at the $10 \%$ level in the CWKC regression (column 1, Table 2.4). This indicates that CWKC does exist, in which case the relationship between per capita urban water consumption and the GDP per capita follows the N curve (Figure 2.4). Peak value of per capita water consumption in urban area appear at different value of GDP per capita for different countries, ranging from several thousand up to around 40 thousand US dollars. This is a result of diversified socioeconomic, demographic, climate and policy factors of various countries.

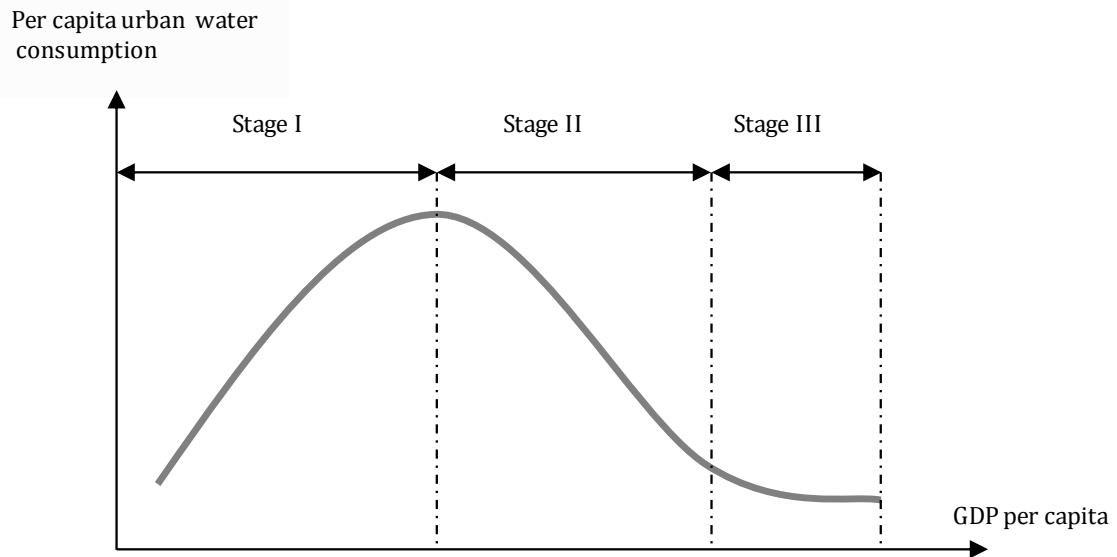

Figure 2.4: The three stages of Cubic Water Kuznets Curve 


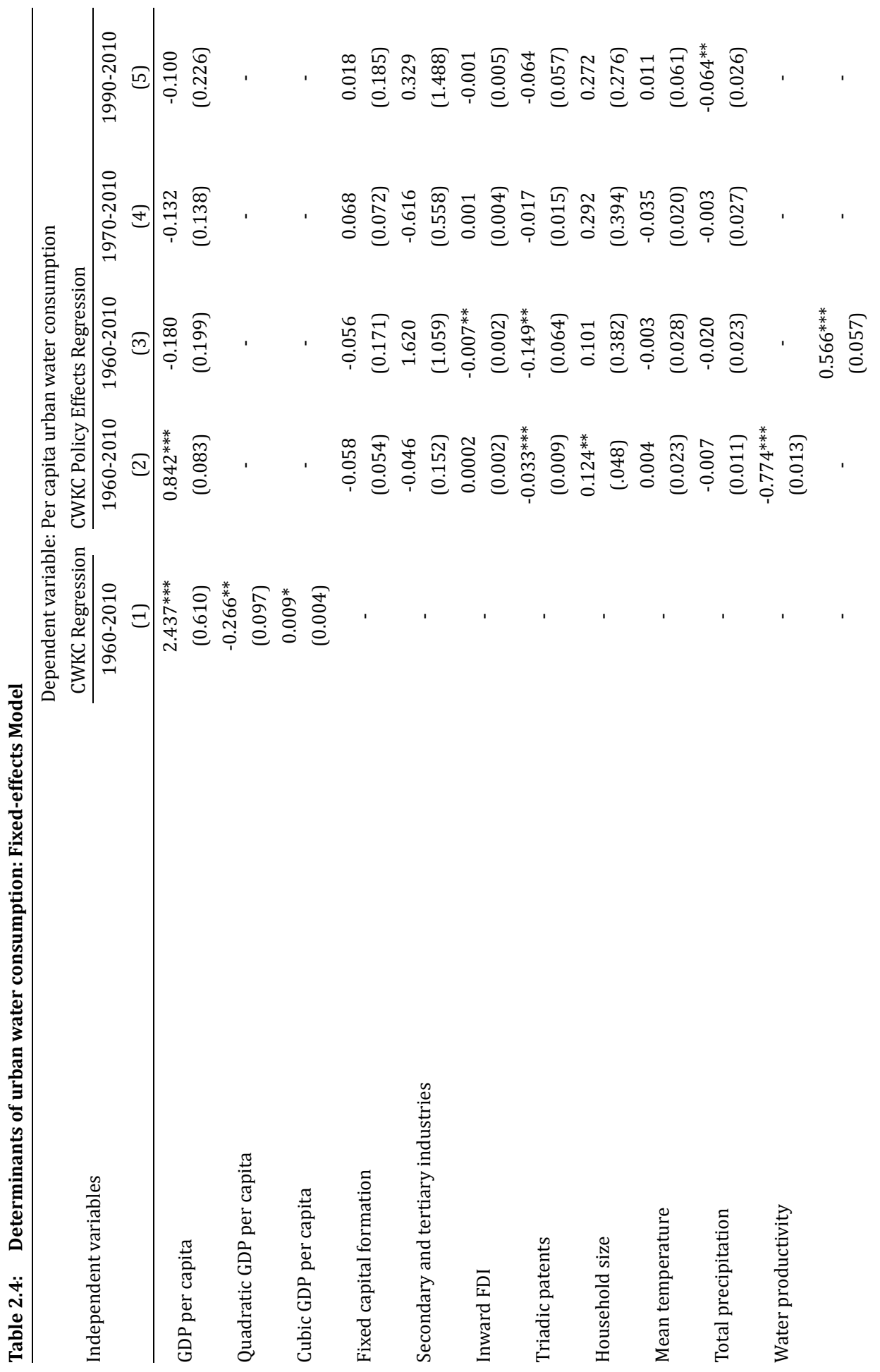




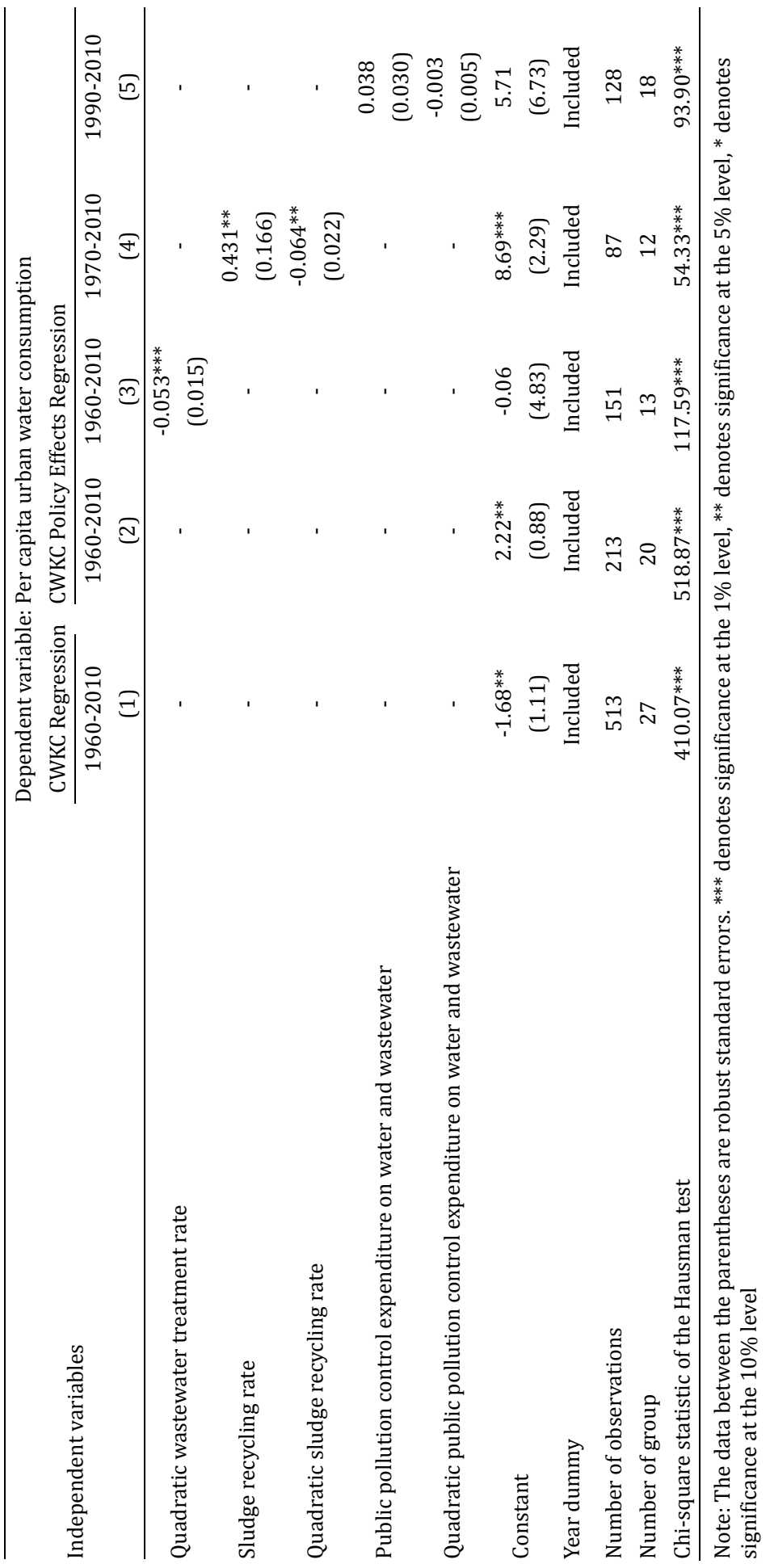


In Appendix B, we show the per capita urban water consumption curve of each country in the observation period. In Appendix C, we present the CWKC of each country during the period of 1960-2010. Interestingly, we only observe the part of the CWKC right to the turning point for Australia, Sweden and Switzerland. Missing the left part of CWKC indicates that the peak values of water consumption per capita of these countries appeared before the sample period. This may be caused by specific socioeconomic characteristics of these countries. For example, all three countries are well-known for the strong environmental awareness among their citizens. It may be also due to their earlier adoption of environmental policies. From the CWKCs for Denmark, Greece, Italy and Luxembourg, we see rather stable or even slight rise of per capita water consumption at the end of the sample period. This may be caused by the aging population and shrinking household size in these countries (Birrell et al., 2005). Small households become the main component in these societies, where the amount of water consumed by domestic activities, such as cleaning and gardening, will be shared by less people, which in turn leads to an increase in per capita water consumption in urban areas.

In the CWKC policy effects regression, we include different policy variables separately in the model. In the regression (2) where we add the water productivity variable, the coefficient of water productivity is negative and statistically significant at the $1 \%$ level, which shows that an increase in water efficiency always leads to a decrease in per capita urban water consumption. The coefficient of the triadic patents is negative and statistically significant at the $1 \%$ level, which reveals that technological development has impact on per capita urban water consumption. The household size variable is positive and statistically significant at the $5 \%$ level, which demonstrates that when the average number of people in a household increases, per capita urban water consumption will increase.

In the regression (3), the wastewater treatment rate is added. The coefficient of the wastewater treatment rate is positive and statistically significant at the $1 \%$ level, while the coefficient of the quadratic wastewater treatment rate is negative and statistically significant at the $1 \%$ level. This implies that at the initial stage of policy implementation, per capita urban water consumption will continue to grow, but if the policy implementation period is long enough, a turning point will appear at a later stage and the per capita urban water consumption will drop. The coefficients of inward FDI and triadic patent variables are negative and statistically significant in the regression, demonstrating that technological development and learning effects contribute to the decrease of per capita urban water consumption.

In the regression (4), the sludge recycling rate is tested as a policy proxy. The coefficient of the sludge recycling rate is positive and statistically significant at the $5 \%$ level, while the coefficient of the quadratic sludge recycling rate is negative and statistically significant at the 5\% level. The similar results for the regressions in column 3 and 4 further prove that only long-term policy interventions will lead to a decrease in per capita urban water consumption. Theoretically, public pollution control expenditures on water and wastewater will also show similar results as compared to those of the regressions (3) and (4). However, both the coefficients of 
public pollution control expenditures on water and wastewater and its quadratic term are statistically insignificant, seen in the regression (5). This may be caused by the short time period of the data for these two variables, as the data for the majority of our sample countries are only available for the period after 1990 . Arguably, with more available public pollution control expenditure data, we may observe a statistically significant relationship between per capita urban water consumption and public pollution control expenditure.

Seen in Appendix C, the GDP per capita of the turning point of the CWKC for the three developing countries in our sample, i.e., China, Mexico and Turkey, are lower than those of the developed countries (Figure 2.5). We argue that this result is mainly due to the direct water policy interventions regarding water and wastewater management in these countries, as this is the main factor differentiating developed and developing countries in the CWKC formation process. It suggests that with proper policy intervention, the turning point of CWKC in developing countries can arrive earlier at a lower income level compared with their counterparts in developed world. Developing countries are thus recommended to implement water-saving policy as they develop economically.

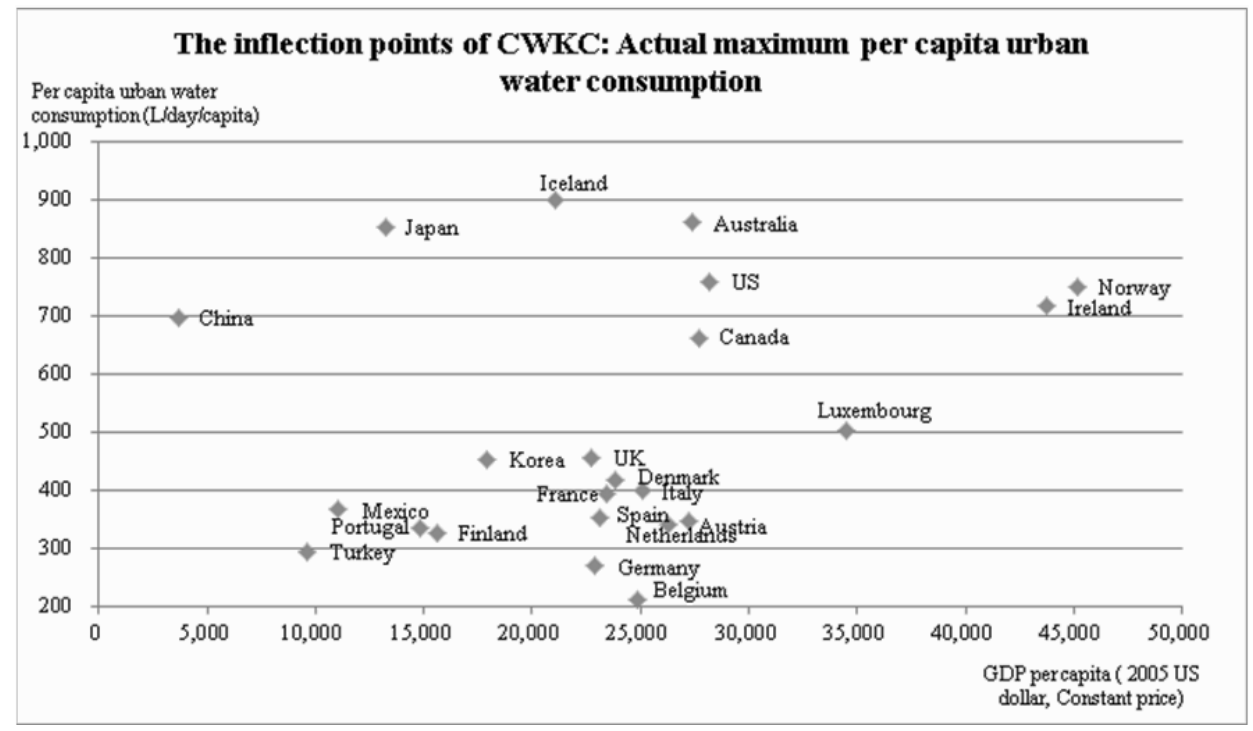

Figure 2.5: The inflection points of CWKC

\subsection{Conclusion}

In this chapter, we propose the Cubic Water Kuznets Curve and test its existence in urban areas based on panel data collected from 27 countries from 1960 to 2010. The relationship between urban water consumption per capita and GDP per capita, i.e., the CWKC, proves to be an $\mathrm{N}$-shaped. In other words, per capita urban water 
consumption will increase at the initial stage of development but decrease after GDP per capita reaches a threshold level. When the GDP per capita reaches an even higher level, per capita urban water consumption can rise again slightly, which we observe in a number of countries in our sample.

Following the EKC literature, we further regress per capita urban water consumption on the factors representing the countries' economic scale and structure, technological improvement, water policy intervention and climate conditions. We believe that the urban water consumption pattern (the CWKC) is strongly affected by policy intervention. We distinguish between two groups of water policies: indirect water policies, which are implemented for certain socioeconomic goals other than saving water but have positive effects on water efficiency, and direct water policies, which aim at better water management. The results showed an inverted-U shaped relationship exists between the direct water policy and per capita urban water consumption, implying that governments can make continuous and long-term efforts to obtain a decrease in per capita water consumption in urban areas.

Further examining the CWKC, we find that the GDP per capita of the turning point of the CWKC for China, Mexico and Turkey are lower than those of the developed countries. We argue that this result is mainly due to the direct water policy interventions regarding water and wastewater management in these countries, as this is the main factor differentiating developed and developing countries in the CWKC formation process. These findings combined bear significant policy implications for developing countries.

With rapid economic growth, population expansion and the acceleration of urbanization, many developing countries face challenges of water shortage and environmental deterioration in the urban areas, which can severely affect perspective of economic development and quality of life of their citizens. However, if longterm water policies are proper designed and rigorously implemented, the stress of water demand in urban areas can be mitigated. The developing countries can then reach the turning point of the CWKC at the earlier stage of development, achieving a better balance between economic development and environment preservation. 



\section{CHAPTER 3}

\section{The reform of urban water management in China}





\subsection{Introduction}

Urban water management is important for a country, as it is closely linked with industry and the daily life of its citizens. Over the past three decades, China has experienced fast economic development, population expansion, rapid urbanization, and environmental deterioration. All of these factors have led to the problem of balancing water supply and water demand in China, particularly in the urban areas. As one of the most important and fragile components of the urban ecological system, water determines the development of cities and the health of their residents. In many cities, water shortages and water contamination are prevalent, and this constrains development and poses great challenges to Chinese water authorities.

Total annual urban water consumption in China has increased by a factor of six in the last thirty years, which implies that the water supply must be increased by 13.78 billion cubic meters per year. Furthermore, rapid industrialization causes serious water pollution, which threatens the urban water supply system. The rapid growth in water demand and the fast deterioration of the aquatic environment raise serious challenges for the Chinese government. Massive investment, advanced technologies and effective management are required to meet increased water demand, solve the rapidly declining quality of water resources and provide secure and safe water.

The traditional methods of urban water management that are based on engineering technologies can hardly cope with these new challenges. Water management reform is needed in China. In the past three decades, Chinese urban water management has undergone dramatic changes from purely engineering-based water management to supply side and demand side management. Water institutions were reconstructed and water legal systems were established. The power for managing water was decentralized to local water authorities, and market-oriented reform was widely adopted in urban water management.

After three decades, reform is still underway with the goal of pursuing sustainable urban water management. We witness the peak value of urban water consumption per capita in 2000 and peak total consumption in 2006 in China. As we showed in Chapter 2, urban water consumption per capita in the urban areas in China follows an $\mathrm{N}$-shaped curve $\left(\mathrm{CWKC}^{3}\right)$. This is consistent with other countries, however, the turning-point value of the Chinese CWKC was much smaller and appeared at an earlier stage of development with much lower per capita GDP. This result is desirable, as the same economic development goals are achieved with less water consumption and fewer environmental externalities. Thus, the Chinese case is of interest for further investigations. Summarizing past experiences of water reform in China, and learning from successes and failures will provide us with powerful tools to address problems in the future.

\footnotetext{
${ }^{3}$ Cubic Water Kuznets Curve. For more detail, please read Chapter 2 of this thesis.
} 
In this chapter, we will first review Chinese urban water management pre-reform then investigate the evolution of water institutions, the establishment of water laws and regulations, and the implementation of related policies in China. Further discussion of two important policies, privatization and public participation, will be made from the angles of supply side and demand side management. Notably, the adoption of privatization and public participation policies in China was characterized by strong government intervention that deserves further investigation.

\subsection{Pre-reform Urban Water Management in China}

The development of urban water management in China before reform can be divided into two stages: the establishing stage that was characterized by a privately owned water sector (before 1949), and the construction and formation stage that was characterized by a fully state-controlled and municipally managed water sector (1949-1978).

\subsubsection{Establishment Stage (Before 1949)}

In China, the history of urban water management can be traced back almost 130 years. The first water supply facility in China was built in Lvshun, a city on the northeastern seashore, in 1879. Its capacity was 1500 cubic meters per day for a population of 20,000. Early urban water management was based on networks with substantial infrastructure, which were initiated and constructed in European and American cities between the 1830 s and 1870 s as a response to deteriorating hygiene in urban areas (Harremoes 1997). In China, early urban water management adopted the Western style of water management, which mainly focused on the construction of water supply infrastructure. During this stage, the water market was completely open and free to enter; no standards or regulations existed yet. Most water plants were managed by foreign private sectors and mainly served foreigners and rich people. A small proportion of the local private sector was also present in the market. Due to World War II and civil war, water infrastructure construction developed slowly. There were only 72 water supply plants constructed and put into use in China before the founding of the People's Republic of China in 1949. Wastewater treatment had already been initiated during this period but received little attention. Based on the available literature, there were only 4 wastewater treatment plants built at this point in China. However, due to free trade and the presence of the foreign private sector in the water market during this period, advanced technologies and management practices were introduced, which formed the foundation of the water sector in China. The water purification process was simple at this stage and mainly relied on sedimentation, filtration and disinfection. 


\subsubsection{Construction and Formation Stage (1949-1978)}

In 1949, The People's Republic of China was founded, and the new Chinese government paid great attention to water sector development and the urban water supply. Securing adequate water resources, constructing sufficient water supply systems and guaranteeing the water supply in the urban areas became the primary objectives at the beginning of this period. By the end of the 1950s, the government mainly focused on fulfilling the basic water demands of households in cities. In the following two decades, from 1960 to 1978, the Chinese government mainly focused on improving the urban water system and meeting the water demand for industries and other sectors. "Water-saving" was on the agenda in a secondary position and did not receive any attention in practice.

At that time, Chinese water resources were in good condition and almost without any contamination or pollution problems, so water quality was not yet an issue. Generally, the water supply in southern China was completely self-sufficient. The main problem was the seasonal water shortage in northern China that was primarily caused by the extremely uneven temporal and spatial distribution of water resources. In fact, securing the water supply in northern China, especially in the Beijing area, was the main water management concern at this stage.

Many water projects were initiated during this period, and the most famous project of all is the South-North Water Diversion Project, a multi-decade infrastructure project that has been proposed as a solution to the seasonal water shortages and variability in northern China. The idea is to divert water from the Yangtze River to the Yellow River and the Hai River, and some other plans were also included. After decades of effort, a total of 44.8 million cubic meters of water were diverted from the South to the North under this project.

The early water management institutions were formed during this stage. The water governance jurisdictions are scattered in different ministries and local governments. From 1949-1954, the Ministry of Water Resources (MWR), Ministry of Health (MOH), Ministry of Agriculture (MOA), Construction Planning Department (CPD) and State Construction Department (SCD) were the main water institutions in China (Shang, 1993). The MOA takes care of all water issues related to the agriculture sector. As rural and agricultural water management is not within the scope of our study, we will not discuss it here.

In this period, the MWR was in charge of all of the affairs regarding water resources, mainly focusing on the construction of hydrological and irrigation systems. In 1958, the MWR and Ministry of Electric Power (MOEP) merged and formed the Ministry of Water Resources and Power (MWREP). Its functions related to water management did not change during the merger. The $\mathrm{MOH}$ is mainly responsible for water management related to health, such as the control of water quality and water borne diseases. 
Between 1949 and 1952, the CPD was one of the departments in the Financial and Economic Committee of the Administration Council. Later, in 1953, it was upgraded to be the Construction Planning Agency (CPA) and placed directly under the control of the National Planning Committee. It took care of industries and infrastructure construction planning and the regulation and monitoring of construction processes. Between 1961 and 1965, the National Planning Committee was dissolved as planning power was decentralized to local authorities. However, with the government adjustment in 1965, it was restored with its original functions. In 1970, the CPD was merged with the Construction Engineering Department (CED), Building Materials Department (BMD) and Central Political Department of Construction (CPDC) to form the new National Planning Committee, which maintained its functions until the reform in 1979.

At the same time, the SCD was established in 1952 and later became the Ministry of Building Construction (MBE) in 1954. The MBE is responsible for all construction projects. The Urban Construction Agency (UCA) was founded in 1954 and is one of the MBE sub-agencies; it is mainly in charge of urban construction. In April, 1955, the UCA was separated from the MBE and became the Administration of Urban Construction (AUC) directly under the control of the State Council. The AUC focuses on urban planning and municipal infrastructure construction. In 1956, the AUC was developed further and became the Ministry of Urban Construction (MUC). The MUC was in charge of guiding the planning and construction of urban areas, drawing up national standards, and regulating construction at provincial and local levels. Soon after, however, the MUC, MBE and Ministry of Building Materials Industry (MBMI) merged into a ministry named the MBE in 1958. Later, the MBE became part of the National Planning Committee, and this situation remained until reform in 1979.

Meanwhile, the central government also recognized the importance of environmental protection and initialed the establishment of related institutions. In May of 1974, the State Council Leading Group Office for Environmental Protection (SCLGOEP), the first governmental institution responsible for the country's environmental protection, was founded. Ideally, it is responsibility for all affairs related to environmental protection at the national level from policy implementation to developing regulations and standards, from overseeing the national environment to developing long-term and annual plans, and from organizing and coordinating environmental research and education to promoting the diffusion of advanced technologies. It also guides and coordinates the environmental protection activities among different departments and different levels of government. In reality, however, this office hardly launched any real works until after ten years of turmoil. Still, its establishment marked the initiation of environmental protection in China.

Corresponding institutions were established to take care of water affairs at the provincial level. Provincial water institutions are controlled by both the national level water institutions and the provincial administrations. At the local level, the 
municipal government is responsible for the construction of specific water systems and their management and maintenance.

At this stage, the division of water management among the different ministries and levels of administration led to a serious overlap of powers that sometimes resulted in conflicts between different government organizations. From 1959 to 1978, the institutional arrangement of water management in China continued without any adjustment due to the Great Leap Forward, natural disasters and the Cultural Revolution, which caused the stagnation of the economic and social development in China.

The construction of water projects and water supply systems was the main objective during this stage. By 1978, the number of cities with water supply systems had risen to 500, which, in total, supplied approximately 63 million cubic meters per day. Few water regulations and standards were issued by the government, but the development of water laws and norms was relatively weak. In 1957, the first water quality standard was issued by the MOH and the MUC that defined and set controls on 16 items. Later, this standard was improved by adding another 7 items to the checklist in 1976. As this was the first water regulation document in history, this standard is a milestone for water management in China.

During this stage, water and wastewater were still managed separately. Wastewater was mainly discharged directly into natural water bodies. Until the end of the 1960s, there were only approximately 10 wastewater treatment plants in China, of which three were built by foreigners between 1921 and 1926 . Wastewater treatment did not receive any attention until the end of this stage when water pollution became problematic in some areas. Though the government started to recognize that wastewater treatment is necessary in the 1970s, the attention and efforts of the government were far too little. By 1978, the number of wastewater treatment plants had increased to 37 but remained far behind the number of water supply facilities. The cost of wastewater treatment was fully covered by government finances.

Water supply was a purely public service completely supported by the government. Water supply systems constructed during this stage were mainly conventional water purification systems and were concentrated in cities, which formed the basic water infrastructure network in China. Residential and industrial users are the major water consumers of the urban water supply. Initially, new water supply systems were constructed based on the technology left behind by foreign companies before 1949. In 1954, the Russian water supply system was introduced and became the standard model in China. Basically, the Russian model is also based on conventional water purification techniques.

In China, charges for water were based on the cost of recovery and a reasonable return on investment during the period of 1949-1955 (Zhong and Mol, 2010). At this time, the government of P.R. China was newly established and had little experience with water management. The majority of the water supply plants were 
those left by foreigners and the private sector. Therefore, it is understandable that the first step was to take over those plants and ensure their normal operation.

Since 1956, radical leftist thought became prominent in China, which led to distorted water prices. This situation continued until 1964, when the first water tariff scheme was proposed by the MWRP. Later, in 1965, this scheme was officially published by the State Council and is seen as the beginning of an era of low water prices in China. Unfortunately, this scheme was not well-implemented in China due to the Cultural Revolution. In the ten years of turmoil that followed, water prices were maintained at very low levels. Although, it is questionable whether the water tariff was properly collected during this period. In this period, water prices were rather equal around the country, so we present the price of water in Beijing to illustrate the general water pricing conditions in China (Jiang and Tang, 2009). Between 1952 and 1966, charges for water were different for different users, but water was charged at a per unit price beginning in 1967. Table 3.1 shows detailed water price information for Beijing from 1952-1978 (Jiang and Tang, 2009).

Table 3.1: Water prices in Beijing, 1952-1978 (Unit: Yuan/cubic meter)

\begin{tabular}{lcccc}
\hline & $\begin{array}{c}\text { Business \& } \\
\text { Municipal Use }\end{array}$ & $\begin{array}{c}\text { Industrial } \\
\text { Use }\end{array}$ & $\begin{array}{c}\text { Government, Public-Sector } \\
\text { Organization, } \\
\text { Force and School Use }\end{array}$ & Residential Use \\
\hline $1952-1966$ & 0.21 & 0.10 & 0.18 & 0.18 \\
$1967-1978$ & 0.12 & 0.12 & 0.12 & 0.12 \\
\hline
\end{tabular}

At this stage, China was under a planned economy, and all of the prosperity belonged to the public and the state. The public sectors, such as energy, water, post, and transportation were completely financed and managed by the government. Those sectors suffered from low productivity and inefficiency.

\subsection{The Reform of Urban Water Management}

\subsubsection{Water Institutions}

By 1976, the ten years of turmoil had ended. From 1976 to 1978, China went through a transitional period in which the government reorganized and reconstructed the socio-economic system. In December 1978, the Third Plenary Session of the Eleventh Central Committee was held in Beijing. A policy of "Reform and Opening up" was proposed and adopted in this plenary, which marks the beginning of the reform movement in China.

As part of the reform, government organizations and institutions were also restructured. From 1978 to 1981, a number of new departments and agencies were established with the goal of pursuing specialized management. Regarding water management, there were three main changes in 1979. First, the AUC and Administration of Building Construction (ABC) were formed under the direct control of the State Council but were temporarily managed by the National Plan- 
ning Committee. The primary task of The AUC is to draft legislation, standards and regulations for urban construction and management. Moreover, the construction, maintenance and management of urban water networks, water plants, drainages and wastewater treatment plants also fall under their sphere of responsibility. Secondly, the MWREP was separated into two ministries, the MWR and MOEP. The MWR is responsible for all water resource affairs, such as formulating water resource development plans and flood control plans for major rivers and lakes, providing guidance for hydrological and irrigation projects, monitoring and supervising related affairs at the national level. Thirdly, a water pricing system based on cost recovery was restored. In 1980, the State Council emphasized the importance of cost recovery to all water projects. In the same year, the MWR organized a water supply cost survey, in which the good economic character of water was mentioned.

In total, 48 new departments were established between 1977 and 1981. This led to a bloated bureaucracy with problems of overlapping responsibilities, overstaffing and inefficiency. In 1982, the State Council decided to simplify the structure of government administration in order to increase efficiency. As a result, 39 departments were dissolved, and the MWR and MOEP again merged to form the MWREP. Moreover, the AUC, ABC, Administration of Surveying and Mapping (ASM) and SCLGOEP were amalgamated into the Ministry of Urban and Rural Construction and Environmental Protection (MURCEP). In 1984, the National Environmental Protection Agency (NEPA), which is jointly managed by the MURCEP and State Council Environmental Protection Committee, was formed.

During the initial stage of reform, water price was determined by provincial and local governments according to the guidance documents from water authorities at the national level, mainly the MWREP, The State Planning Committee (SPC) and the Administration of Prices (SAP). Later, the power to set water tariffs reverted to the central government. In 1977, the State Administration for Commodity Prices (SACP), which is in charge of managing commodity prices, was founded. In 1994, The SACP merged with the SPC, which was renamed the National Development Planning Commission (NDPC) in 1998. In 2003, the State Council Office for Restructuring the Economic System (SCORES), which is part of the State Economic and Trade Commission (SETC), and NDPC jointly formed the National Development and Reform Commission (NDRC), which became the authority over water tariffs.

In 1988, China unveiled its cabinet reshuffle plan. After the reshuffle, the MWREP split into the MWR and MOEP again, and all water related functions now belonged to the MWR. The NEPA was separated from the MURCEP and upgraded to the Ministry of Environmental Protection (MEP). The restructured MURCEP was renamed as the Ministry of Construction (MOC), which was later renamed the Ministry of Housing and Urban-Rural Development (MOHURD) in 2008. In 1998, the Ministry of Land and Resources (MLR) was set up, which was an amalgamation of the former Ministry of Geology and Mineral Resources (MGMR), the National Bureau of Land (NBL), the National Bureau of Oceanography (NBO) and the National Bureau of Surveying and Mapping (NBSM). MLR is mainly responsible for 
all affairs concerning land, mineral and marine resources. It is also in charge of monitoring and preventing the over-extraction and contamination of ground water.

Under the new administrative institutional arrangement, urban water is managed by six different ministries. The MWR is in charge of all affairs related to surface water. The MLR is responsible for underground water monitoring and protection. The MOC takes care of water networks, water supply and drainage in cities. The MEP is responsible for water quality control, wastewater monitoring and treatment. The MOH controls water quality related to health. The water tariff is managed by the NDRC under consultation with the MWR and MOC. Generally, the institutional division of responsibilities at the national level is reflected in equivalent agencies at each of the lower levels ${ }^{4}$ of government. Water authorities at lower levels are under the control of both governments at the same level and the corresponding authorities at higher levels.

The arrangement of Chinese water institutions reflects the history of their formation and the strong control of the central government. Generally, policies and laws are set centrally but administered locally. Therefore, the institutional arrangement combines the multi-level jurisdictional framework: national, provincial, prefecture and county levels. Under the new arrangement, water governance jurisdictions are scattered through different ministries and local governments. The associated management is costly due to the complexity, the need for a high level of consistency and the involvement of multiple government agencies that each has their own priorities. When combined with the need to provide a highly reliable water supply to a diverse range of users, urban water management is arguably the most challenging component of overall water management in China.

\subsubsection{Water Laws and Regulations}

Water legislation in China was lagging when the country initiated its reforms in 1978. By the end of the 1970s, even though the government paid a great deal of attention to water management and environmental protection, water legislation was almost nonexistent, and only a few management documents were issued by the State Council. The Water Pollution Prevention and Control Law issued by the Standing Committee of the National People's Congress in 1984 marked the initiation of water legislation in China. In 1988, the Standing Committee of the National People's Congress issued the Water Law. These two laws are the foundation of water management in China and determine the basic principles of the management of water resources.

The 1984 Water Pollution Prevention and Control Law clearly states that water resources must be protected and that pollution should be prevented and treated; governments at different levels should supervise and carry out water pollution prevention; the protection of urban water resources and pollution prevention

${ }^{4}$ The hierarchy of the Chinese government includes four levels of governance: central, provincial, prefectural and county. 
should be integrated into urban development; drainage networks and wastewater treatment facilities should be built and improved. Water quality standards and pollution emission standards were formulated and written into this law. Industries are required to register and report their wastewater treatment and discharge. Meanwhile, any new project that will discharge wastewater should have an environmental impact statement and obtain approval from environmental authorities; otherwise, it is not allowed to be built and used.

The 1988 Water Law provides the legal basis for the development, utilization and protection of water resources as well as the prevention and control of water hazards. Under this law, water is defined as state property that belongs to all citizens. Basically, water exploration and use are planned in China, but saving water is not specifically mentioned in this law. The development and utilization of water resources and the prevention of water damage should be planned at the regional level or the level of river basins. Water is governed by the State Council at the national level. A licensing system for water drawing is implemented based on a comprehensive survey and assessment of water resources. Moreover, the 1988 Water Law clearly defined the water-user pays principle, which is the basis of the market-oriented reform of the water sector.

In the 1990s, China underwent rapid economic development and urbanization, which greatly challenged the management of urban water. The implementation of the 1988 Water Law and the 1984 Water Pollution Prevention and Control Law encountered many problems that led to revisions of those two laws.

The Water Pollution Prevention and Control Law was amended twice, once in 1996 and once in 2008. The 1996 revised Water Pollution Prevention and Control Law strengthened all aspects of water pollution control and abatement, defined the polluter-pays principle, and granted more rights for pollution abatement to local governments. The 2008 amendments further improved the relevant provisions under the law, such as more stringent monetary sanctions for pollution abatement and stricter penalties for incidents, and established the system for setting responsibility targets and the nationwide monitoring system. The combination of total pollution control targets and industry-specific discharge controls became powerful tools for pollution control and abatement. Moreover, public participation in water protection and pollution control activities is promoted by the amendments. However, monitoring and sanctions for illegal discharge still need to be improved. In some cases, the existence of management and regulatory loopholes leads to rent-seeking behavior. Furthermore, inadequate civil liability and weak administrative liability lead to high costs for enforcement and compliance and low costs for illegal behaviors. The difficulty of obtaining evidence of violations has also caused serious abuses of the pollution prevention law.

Revisions to the Water Law were initiated in 1994. However, it took almost eight years of preparation and revision before the official issuance in 2002. A great deal of work, mainly investigations and consultations at different levels of government, was completed during the preparation period. Compared with the 1994 Water Law, 
the revised version gives more attention to water resource management at the national level. China is defined as a water-scarce country that suffers from water shortages and water contamination. Saving water is emphasized and promoted by the revised water law through a provision that requires water withdrawal to be strictly controlled and regulated by a licensing system and controlled by quotas set at the national level. Charges for water are based on metering and an Increasing Block Tariff (IBT) ${ }^{5}$ system for going over quota. The good economic character of water is highlighted to promote water saving behaviors. Moreover, river basin management is emphasized; the water extraction plan of the administrative region within the basin should obey the plan for the river basin. Industrial outfall is forbidden in the protected areas for drinking water resources.

Based on these two basic laws, related administrative laws and regulations were developed and enacted with the aim of establishing a comprehensive legal framework for water management. At the provincial, prefecture and county levels, governments are allowed to issue even stricter regulations and rules in their jurisdictions than those of higher levels of government.

Over the past three decades, water policies and regulations have been made, adjusted and improved over time under the guidance of two basic laws with the goal of meeting the needs of national economic development and human welfare. In general, five groups of urban water management regulations can be identified: 1) water allocation regulations, 2) regulations related to water production and water quality, 3) water tariff regulations, 4) water consumption regulations, and 5) wastewater regulations. These regulations and policies are part of a broader context relating to water management, urban planning and environmental management. As those regulations and policies are made by different administrative agencies with different objectives relating to urban water issues, they sometimes need to be aligned.

Water allocation in urban areas is closely linked with the plans, which are mainly created by the MWR, that determine how water will be made available for different consumptive purposes in a river basin and within the administrative regions within the basin (Sheng and Speed, 2009). Water availability is determined on a yearly basis according to the "annual water resources regulation plans". Water extraction by different users is governed by a "water abstraction permit system" that was created by the 2002 Water Law and the 2006 Regulations on the Administration of Water Abstraction Licensing and Collection of Water Resources Charges. Permits are regulated through "annual water abstraction plans", which must be consistent with the relevant annual water resources regulation plans. In periods of extreme drought, 'drought contingency plans' take precedence over other plans and require amendments to the annual water abstraction plans. These contingency arrangements are primarily designed to protect the availability of

\footnotetext{
${ }^{5}$ Increasing Block Tariff (IBT): "a price structure in which a commodity is priced at a low initial rate up to a specified volume of use(block), then at a higher or several increasingly higher rates for additional blocks used (Whittington, 1992)."
} 
water for urban users, particularly for essential domestic needs, who are given priority under the 2002 Water Law. In urban areas, permits are generally held by the water supply entities that provide services to the urban end users ${ }^{6}$. The rights and responsibilities of the suppliers and users related to the ongoing and annual entitlements to water are governed by both "water supply and use contracts" between these parties and by the suppliers' water supply plans. These plans and contracts cover matters such as the price paid for water services, the rate and pressure of the water supply, the metering obligations and standards for meters, and the quality of the water supplied.

The MOHURD and its local equivalents ${ }^{7}$ are technically responsible for the development of urban water sources and their delivery networks under the 1994 Urban Water Supply Regulations. Water quality is one of the most important criteria in urban water management. Urban water quality is regulated by the 1989 Urban Planning Law, the 1994 Urban Water Supply Regulations, the 1999 Contract Law, the 2006 Regulations on the Administration of Water Abstraction Licensing and Collection of Water Resources Charges, and the 2007 Urban Water Supply Quality Regulations. National drinking water quality standards are set by the $\mathrm{MOH}$ and must be met by urban water suppliers when their water is delivered for domestic use. The first drinking water standard created since 1979 was the sanitary standard for drinking water, GB 5749-85, issued by the MOH in 1985 and revised in 2006. In between, the $\mathrm{MOH}$ also issued a sanitation criterion for drinking water in 2001, which is viewed as a transitional standard. Compared to previous standards, the GB 5749-2006 contains 42 regular monitoring items and 64 irregular monitoring items, which could provide better control of drinking water quality. The MOHURD also issued two urban water supply water quality regulations for water suppliers in the sector: the Urban Water Supply Water Quality Standards, CJ/T 2062005, and the Water Quality Standards for Fine Drinking Water, CJ 94-2005, in 2005 , which aim to better regulate the water sector and guarantee the quality of water supplies.

Water tariff reform is seen to be of central importance to water sector reform in contemporary China. Water prices used to be controlled by the state, but this power was released to the municipalities as part of decentralization. As it is believed that the price of water should be appropriate to local conditions and social affordability. The first water rate regulation issued after the start of the reform concerned water prices, and the Measures for Price Administration of Water Engineering were issued by the State Council in 1985. This regulation clearly defined the good economic character of water; the user pays the principle. Different water prices should be charged for different users. This regulation was used as the legal basis for making specific water tariff regulations at the provincial, prefectural and city levels. Following the market-oriented reforms, the water pricing system is further clarified in the 1998 Administrative Regulation on Urban Water Supply Pricing. This regulation states that the general principles of setting

\footnotetext{
${ }^{6}$ Some major industrial users operate their own water abstraction and supply systems.

${ }^{7}$ Urban Construction Departments
} 
water tariffs are "cost recovery, reasonable revenue, water conservation and social equity". In other words, the water tariff should cover operation and maintenance, depreciation, interest costs, taxes and provide appropriate profit to the water suppliers. In 2002, the NDPC, Ministry of Finance (MOF), MOC, MWR and SEPA jointly issued the Notice on Promoting Reform of Pricing of the Urban Water Supply. This notice aimed at promoting further water tariff reform by adopting an IBT system to stimulate water saving behaviors among different users. Since then, the IBT system has gradually been adopted in China and mainly in the big cities. In January 2014, the NDRC and the MOHURD jointly issued the normative document, Guiding Opinions on Establishing and Perfecting Urban Water Tiered Pricing Systems, which affirmed the effectiveness of IBT systems for saving water. Currently, the IBT is being promoted in China with the target of full adoption in all cities by 2015. This tariff system consists of a fixed demand charge and an increasing block price; the fixed block should meet the basic needs of the residents. Public hearings and notices are required and conducted as part of the decision making process for setting water tariffs.

The use of water in China's urban areas is subject to planned water use and the water saving system under the national Regulations on Urban Water Saving Management of 1988, which is designed to minimize water waste and increase water use efficiency. This system requires the preparation of an annual water use plan for the city as a whole as well as for individual, non-residential users. Municipal annual water use plans define the way that water available to the municipality is to be used. Annual water use plans for non-residential users effectively provide a yearly allowance. These allowances depend on water use quotas for different classes of users in the region that are intended to normalize water use by particular industries; the quotas are set for a single unit of production or service for similar users in a region. The 2002 Water Law requires local municipal governments to improve domestic water use efficiency by promoting the use of watersaving appliances within households, reducing leakage from the supply networks and increasing the use of recycled water. Under the 1994 Urban Water Supply Regulations, municipalities are required to prepare medium to long-term plans to meet the growth in water demand in the cities, which must be coordinated with the water allocation planning framework to ensure the sustainable use of water resources.

In urban areas, wastewater discharge is managed through a national urban drainage permit system under the Methods on Urban Drainage Permit Management of 2007 (Cosier and Shen, 2009). This system uses urban drainage permits and urban drainage plans to regulate the quality, quantity and flow of wastewater that enters drainage and treatment facilities. Local drainage departments are required to regularly test discharged wastewater to ensure that the quality meets the national requirements of the 1996 Comprehensive Standard of Sewage Drainage, and lack of compliance can lead to cancellation of the drainage permit. Later, the MEP published the pollutant discharge standard for municipal wastewater treatment plants in 2002. Meanwhile, industry-specific sewage drainage standards were also issued in 2005 and 2006 and partly replaced the national Comprehen- 
sive Standard of Sewage Drainage of 1996. In some situations, urban users are authorized to discharge wastewater directly into watercourses. These situations are assessed on a case-by-case basis and require approval under a separate permit system from the local environmental protection department (2008 Law on the Prevention and Control of Water Pollution). However, the distinction between the two systems is not entirely clear. In recognition of the overlaps, the 2008 government restructure resulted in certain information-sharing requirements between the MWR and MEP. In particular, the two ministries are required to agree on any new water quality standards or information to be publicly released to ensure that there is a single government dataset. Further emphasizing wastewater treatment and urban water management, the State Council issued the Regulation on Urban Drainage and Sewage Treatment by the end of 2013. The promulgation of this regulation shows that the state is devoting more attention to urban drainage and sewage treatment and is making efforts to approach integrated urban water management. Under this new regulation, the responsibilities and duties for managing drainage and sewage treatment facilities are clearly defined. The introduction of market mechanisms and the consideration of social forces in wastewater management are highlighted. Franchises, government procurement of services and other participating forms of social capital are encouraged in the construction and operation of drainage and wastewater treatment facilities. Issuing this regulation shows that the government would like to push the market-oriented reforms of sewage treatment forward and further promote integrated urban water management in China.

\subsubsection{Water Policies}

The reform of urban water management in China is characterized by the empowerment of local governments in financial, administrative and economic issues (decentralization), an emphasis on market roles (marketization), and the acknowledgement of individual economic activities (privatization) with the aim of establishing integrated urban water management. The direction of urban water management reform is consistent with the direction of reform in the country overall. Moreover, the reform of Chinese urban water management is also strongly affected by the international trends in public sector reforms, initiated by Thatcher's government in the UK, since the 1980s.

Before reform, traditional urban water management in China was highly centralized at the state level; all projects had to be approved and financed by the central water authorities based on the plans. The price of water was set at the national level and was very low so as to hardly cover the cost of water production. The operation and maintenance of the water supply and wastewater treatment systems were the responsibility of local municipalities. Little attention was paid to wastewater management at this stage.

Initially, urban water management reform mainly focused on restoring and restructuring the urban water management system by adopting decentralization 
policies and implementing business administration practices in the water sector. The concept of the economic good of water, that water should be paid for by all users, was clearly mentioned in the No. 1 Central Document in 1982 and was further emphasized in the 1985 State Council regulation "Hydraulic Projects Water Fee Approval, Valuation and Management Measures". Water institutions were built up and a series of water related laws and regulations were issued. The power and responsibility for urban water management were gradually decentralized to local water authorities and municipalities. Under the decentralized system, the central government guides and regulates urban water management through a series of policy documents, laws and regulations while the local governments and municipalities take responsibility for water management in their jurisdictions by making and implementing specific regulations. Decentralization not only relieves the central government of the burden, but it also empowers local governments by giving them more decision-making and implementation rights. Water resource endowments are different among regions, and decentralized management allows local governments to better design appropriate plans and regulations, which facilitates improvements in the production and efficiency of urban water management.

Urban water management in China shifted from focusing on supply side management to emphasizing both the supply side and the demand side. During the initial stage of reform, the priority was to establish a well-functioning urban water management system. Following economic development, water demand in urban areas in China increased enormously. Water shortages and water pollution became notable in urban areas, and the Chinese water authorities recognized that merely focusing on water supply management was not enough and that ignoring the demand side would lead to tragic results. Therefore, demand side management (Chen et al, 2005), which focuses on water conservation and public participation, was launched. Since the mid-1990s, both supply side management with marketoriented policies and demand side management based on water conservation and public participation policies were adopted and implemented in China.

On the supply side, market-oriented policies were largely adopted during the reform of urban water management in China, which aimed at establishing a property rights system, constructing a water market, and privatizing the water sector. As one of the core policies of the market-oriented reform, privatization greatly contributed to the water sector boom in China. The privatization of the water sector was characterized by foreign private sector participation, domestic private sector development and government policy interventions that were initiated with trail projects and then gradually extended. The timely adjustment policies not only facilitated the privatization of the water sector but also reduced the risks of failure during reform.

Complementary to supply side management, demand side management has been emphasized in the water sector since the mid-1990s. The shift from supply side management to simultaneous supply side and demand side management was mainly proposed as the solution to rapidly increasing water demand and the 
dramatic deterioration of the aquatic environment. Beginning in the mid-1990s, water conservation policies were adopted as one of the main demand side management strategies. Water conservation was written into the 2002 Water Law as one of the core objectives of water management. Meanwhile, Water Conservation Offices (WCOs) were established at both the central and local levels in order to stimulate water use efficiency and conservation. Public participation was also emphasized as one of the important components of demand side management as it is crucial to the successful implementation of water conservation policies. As end users and active actors in urban water management, the public's behavior directly affects water consumption patterns and the urban water environment.

Following socio-economic development and urbanization in China, integrated urban water management is required to realize sustainability (Harremoës, 1997). Integrated water management is a strategy that brings together all facets of the urban water cycle (water supply, sewage management, wastewater treatment and stormwater management) to achieve sustainable urban water management. Since the 2000s, the implementation of integrated water management in China has been an important strategy along with market-oriented reforms. Internationally, it is widely accepted that wastewater and stormwater are important components of the water system that should be addressed along with the water supply. By failing to address wastewater and stormwater issues, the availability of water resources and the urban water supply are threatened. Integrated urban water management is proposed as the solution along with simultaneous supply side and demand side management with the goal of realizing sustainable urban water management. This is the new target of the current reform stage in China. In fact, the new "Urban Drainage and Sewage Disposal Ordinance", issued by the state council in October 2013 and implemented since January 2014, reflects the government's efforts in this regard. The newly issued ordinance clearly shows that the Chinese government aims to achieve integrated urban water management by reforming wastewater and stormwater management. According to the ordinance, the government encourages franchising, procurement of services and other forms of social capital participation in the sector. This is consistent with the reform strategies adopted by the urban water sector, namely market-oriented reform. From another perspective, this also reflects the government's affirmation of the market-oriented reforms in the urban water sector.

Two of the most important and distinctive reform policies, privatization and water conservation through public participation, are worthy of further discussion in the following sub-sections.

\subsubsection{Supply Side Management-Privatization}

Privatization has been proposed and advocated as a political strategy to address the low productivity and inefficiency of public water firms. Privatization is largely situated within the set of "neo-liberal" reforms that promote economic liberalization, open markets, privatization and deregulation (Robison and Hewison, 2005). In the context of the water sector, the objectives of privatization are 1) achieving greater efficiency in the allocation and production of water, 2) improving the 
financial capabilities of governments, 3) strengthening the role of the private sector in the economy and 4) releasing financial resources for use in other sectors (Idelovitch and Ringskog, 1995; Sheshinski and Lopez-Calva, 2003).

Theoretically, privatization is supported by property rights theory, welfare economics theory, principal-agent theory and public choice theory. According to these four theories, privately-owned water firms perform better than publicly-owned ones within the context of a well-structured market and effective regulatory policies (Vickers \& Yarrow, 1989). If the private sector is not well regulated, merely privatizing the water sector and opening up the water market will most likely not lead to enhanced productivity. Hence, we argue that the effectiveness of water sector privatization largely depends on the construction of a water market that ensures effective market competition and provides good regulations.

Internationally, many developed countries suffered from heavy financial burdens, low productivity and high inefficiency in the urban water sector in the 1970s. In 1989, water sector privatization, which was advocated as the solution to these problems, was initiated by the Thatcher government in the UK. This trend soon spread all over the world. Since the beginning of the 1990s, the privatization of the water sector became prevalent in the developing world, mainly in Latin America and Asia. In those countries, water sector privatization was characterized by massive participation by multinational water firms. Unexpectedly, by the end of the 1990s and the beginning of the 2000s, there were massive withdrawals from the water sector by international water companies in the developing world. Many of those plants were returned to the public. However, while we have observed the substantial withdrawal of international water companies from many developing countries, we have also seen the persistence of water privatization and the participation of multinational water firms in China.

In China, privatization has been one of the core policies of the market-oriented reforms in the water sector since the 1990s, which aimed at releasing the government's heavy financial burden, upgrading lagging technologies and improving the productivity and efficiency of the water sector (Browder and Xie, 2007). In many developing countries, water privatization was based on neo-liberal theory and fully adopted through deregulation. In contrast, the privatization of the water sector in China was implemented gradually and accompanied by institutional reforms, the construction of a legal system and government interventions.

The period from 1984 to 1992 could be identified as a preparation period, in which the central government focused on restoring water institutions and establishing the water legal system. Funding methods for water projects were adjusted and extended from government financial allocations to bank construction loans, selffinancing or foreign capital. During this period, 150 water supply projects, which cost up to 1.8 billion US dollars, were funded by long-term preferential loans provided by international banks and the governments of developed countries. Although all water firms were still fully owned by the state, enterprise management was adopted by water firms in order to achieve high productivity and 
efficiency. Unfortunately, the effects of the reforms in this period were limited due to the lagging water price system and lack of distinction between the functions of the government and those of the enterprises.

From 1992 until 2001, the market-oriented urban water sector reforms in China entered a propulsive period. At the beginning of this period, the central government banned the municipalities from guaranteeing financing, so capital began to enter the sector through cooperative forms of investment. This period is characterized by foreign private sector participation in the urban water sector, mainly through pilot projects. In 1992, Sino French Water partnered with Zhongshan Tanzhou Municipal Economic Development Company to establish the first Sinoforeign joint water supply venture in China, Zhongshan Tanzhou Water Supply Company Limited. Consequently, similar projects were carried out, mainly in the coastal cities. During this period, joint ventures, which required more than $50 \%$ of the shares to be held by a domestic partner, were the main form of private sector participation in the water sector.

The positive results from the joint venture projects and the severe lack of funds impelled the government to further promote reform in the water sector. The BuildOperate-Transfer (BOT) model was adopted and promoted by the Chinese government beginning in the mid-1990s via the promulgation of the Circular on Attracting Foreign Investment through the BOT Approach (No. 89 Policy Paper of 1994, the former Ministry of Foreign Trade and Economic Cooperation, January 16 of 1995) and the Circular on Major Issues of Approval Administration of the Franchise Pilot Projects with Foreign Investment (No. 208 Policy Paper of Foreign Investment, the former National Development and Planning Commission, the Ministry of the Electric Power Industry, and the Ministry of Communications, 1995). These two policies provided legal ground for private sector involvement and foreign capital investment in the Chinese water sector for the first time. In 1997, the first BOT (Build-Operate-Transfer) project was approved by the National Development and Reform Commission, the Chengdu No. 6 Water Supply BOT Plant. Through international public tender, the Générale des Eaux (CGE) of France ${ }^{8}$ and Marubeni of Japan consortium won this project. The BOT model was also promoted in wastewater treatment projects but to a lesser extent. The first wastewater BOT project, the Beijing Economic Development Zone Wastewater treatment plant, was launched in 2001.

Meanwhile, the government also encouraged self-reform of the state-owned water enterprises. In 1999, the "Decision of the Central Committee of the Communist Party of China on Major Issues Concerning the Reform and Development of StateOwned Enterprises" was passed at the Fourth Plenum of the $15^{\text {th }}$ CPC Central Committee, which advocated shareholding reforms and the listing of the securities of state-owned enterprises. In the water sector, this led to the self-reform of largescale, state-owned enterprises, and a group of state-owned water enterprises was

${ }^{8}$ Générale des Eaux (CGE) changed its name to Vivendi in 1998. 
listed ${ }^{9}$. Some listed Chinese corporations also showed great interest in the water sector and took the opportunity to enter it ${ }^{10}$.

Corresponding reforms were carried out on the water pricing system. "Urban water price management measures", issued in 1998, clearly defined the profit rate that provided favorable conditions to private investors and boosts private sector participation in the sector. However, the power for setting water prices and constructing and operating the water network were still controlled by the municipalities. Foreign investment was limited to joint water purification ventures and wastewater treatment projects. Profit is obtained by selling water/treated wastewater to the municipally-controlled water companies. In order to attract investors, a fixed rate of return on investment became one of required clauses in the joint venture contracts of this period. The high fixed investment rate of return, usually between $12 \%$ and $18 \%$ but up to $30 \%$, created a heavy burden for the water companies and consumers. The central government realized the seriousness of this problem and took timely measures to intervene. In 2002, the State Council issued "Notice on the proper handling of existing guaranteed fixed return of foreign investment projects and related issues". The notice explicitly stated that the previous terms for foreign investors were unfair to Chinese competitors and that guaranteeing a fixed rate of return was illegal. On-going contracts should be revised, and new contracts should contain fair terms and conditions for both foreign and Chinese partners.

The full commitment of the Chinese government to private involvement in the water sector dates from 2002. In March 2002, the State Council updated the "Catalogue for Guiding Foreign Investment" in which water distribution networks and drainage systems are classified as fields open to the foreign private sector. This regulation has allowed foreign investors to secure revenues from management of the water supply and drainage networks, which reduces some degree of the risks to investment. In December 2002, the MOC issued "Opinions on Accelerating the Marketization of Public Utilities" (No. 272 Policy Paper of the MOC, 2002), which marked the initiative of the comprehensive market reform phase of the Chinese urban water sector. According to this policy paper, multi-financing approaches, concession rights and concession management, price mechanisms, reduction of the governmental monopolies and government roles ended the traditional policies of the public utilities in China. Moreover, the subsequent "Measures for the Administration on the Franchise ${ }^{11}$ of Municipal Public Utilities" (No. 126 Policy Paper of the MOC, 2004) specifies the procedure for involving the private sector in public utilities by awarding concession rights, but it still relies heavily on BOT models. The public bidding process became standard procedure for any urban water service contract (Lee, 2010).

\footnotetext{
${ }^{9}$ For example, Shanghai Municipal Raw Water Co., LTD; Wuhan Sanzhen Industry Holding Co., LTD; Nanhai Development Co., LTD.

${ }^{10}$ For example, Beijing Capital Co., LTD; Qianjiang Water Resources Development Co., LTD.

${ }^{11}$ Refers to all forms of private sector participation.
} 
In contrast to the privatization of public utilities in other developing countries, the Chinese government has persisted in placing great importance on regulating the sector. "Opinions on Strengthening Regulation of Public Utilities" (No. 154 Policy Paper, the MOC, 2005) further emphasized that the water sector provides basic public and social goods, so governmental regulation remains essential (Zhong et al., 2008).

Simultaneously, the government kept supporting the self-reform of state-owned water companies and promoting the participation of the domestic private sector in the water sector. Two important policy papers were issued, "On issuing of promotion and guidance of private investment in a number of opinions" (No. 2653 Policy Paper, the SPCC, 2001) and "Several Opinions of the State Council on Encouraging, Supporting and Guiding the Development of Individual and Private Economy and Other Non-Public Sectors of the Economy" (No. 3 Policy Paper, the State Council, 2005). Those two policy papers clearly showed that the Chinese government greatly supports the growth and participation of the domestic private sector in public utilities. Many domestic private enterprises are actively involved in the water sector, and some of them became leading companies in the sector, such as the Sound Group and the Tsinghua TongFang Company.

The period from 2002-2007 is characterized by the foreign private sector being actively involved in the Chinese water sector through different means, such as BOT projects, joint ventures, the acquisition of equity, management contracts, etc. In many places, the foreign private sector entered the water sector through high acquisition premiums, sometimes up to 1.5 times the equity transfer price ${ }^{12}$. This high foreign acquisition premium for Chinese water companies was mainly caused by competition in the water market among foreign private companies. Local governments benefited from the high acquisition premiums of the state-owned water companies through the release of the financial burden and increased revenues. Some municipalities even wrote acquisition premiums as hard rules in the tender ${ }^{13}$. Subsequently, high acquisition premiums led to some significant problems. Obviously, the motivation for foreign private sector investment is profit, but when high acquisition premiums occur, the foreign private sector will either transfer its costs to consumers by increasing water prices or reduce its investment in other ways, such as slowing facility renovations. In fact, water prices increased quickly in many places where acquisition premiums were high.

In 2007, the China Environment Service Industry Association issued an announcement blaming acquisition premium behavior and noting that it is a short-term asset based on government finance gained at the cost of future water yields and water revenues. The association also reported the problem to the central govern-

\footnotetext{
${ }^{12}$ In May 2002, Veolia won the international tender for the 50 year contract to operate and manage the Shanghai Pudong Water Supply with an acquisition premium of the Shanghai Pudong Water Company of more than $50 \%$ and $50 \%$ equity.

${ }_{13}$ The Tianjin North Water Co. LTD equity transfer project tender (2007) required a minimum $30 \%$ acquisition premium.
} 
ment. The central government responded to this problem quickly by drafting the "Cost Supervision and Examination of Urban Water Pricing (for trial implementation)"14 that same year. This document aims at regulating water prices and avoiding excessive price hikes. Public pressure and central government interventions slowed down the process of transferring premium stock rights to foreign investors in many places. Many municipalities rethought their water sector development strategies and chose different development modes, such as the case of the Xian Water Company. Instead of attracting foreign investors, Xian Water Company decided to carry out self-restructuring. Group strategy management was adopted to achieve integrated urban water services from the water supply to wastewater treatment and discharge.

The slowdown of foreign private sector investment in the Chinese water sector provided more opportunities for the domestic private sector. In addition, the central government also adjusts its policies and strongly promotes the growth of the domestic private sector. In May 2010, the State Council issued "Guidelines of the State Council on Encouraging and Guiding the Sound Development of Nongovernmental Investment" (No. 13 Policy Paper, the State Council, 2010). This policy paper shows that the central government will continue to support market-oriented reforms in the water sector while further improving the water legal system. Domestic private investment is encouraged in public utilities. As the competent authority, the MOHURD further issued a related policy paper (No. 89 Policy Paper, the MOHURD, 2012) in order to promote domestic private sector participation in the water sector.

Currently, efficient drainage and wastewater treatment are essential parts of the urban water system. In China, wastewater treatment has been emphasized since the 1990s when environmental deterioration became serious in urban areas. Although similar market-oriented reforms were carried out for wastewater treatment management, the results lagged behind those for water supply management. This is mainly due to 1) the lack of an effective government regulatory system and incentives, 2) the absence of a fair market environment, 3) the lack of a well-implemented charging system, 4) difficulties in and high costs of financing, and 5) lack of an integrated industrial chain. In order to properly address those problems and promote sustainable urban water management, the central government issued the "Regulation on Urban Drainage and Sewage treatment" (No. 641 Regulation, the State Council, 2013). In this new regulation, the rights and responsibilities of the different actors in the sector were clearly defined. The positive results obtained through market-oriented reforms over the past three decades were affirmed, and further reform is promoted. The investments of different forms of capitals, especially domestic social capitals, are encouraged in drainage and wastewater treatment facilities. This regulation reflects the great importance that the Chinese government attaches to drainage and wastewater treatment and its determination to establish an integrated urban water management system.

${ }^{14}$ It was officially published and implemented in 2010. 
As supply side management tools, marketed-oriented reforms accompanied by the privatization of China's water sector were characterized by strong government interventions. Water policies and regulations were designed and adjusted over time in order to address different problems that appeared during the development of the water sector and to promote the growth of the sector. The initial stage of reform mainly focused on attracting investment, transferring technology and learning management skills through foreign private sector participation. Meanwhile, the government stimulated the self-reform of the state-owned water companies and supported the growth of the domestic private water sector. Cooperation between the foreign private sector and domestic partners were required and promoted, which greatly facilitated the transfer of technology and tacit knowledge. This led to the fast growth of domestic water enterprises, both public and private. In the later stages of reform, the central government focused on supporting the development of the domestic private sector and state-owned water enterprises by providing more incentives. The policy shift greatly contributed to the development of the Chinese water sector and the fast growth of Sino water enterprises. Undoubtedly, the government also encountered many problems during its water sector reforms, but in general, we are witnessing fast growth and prosperity in the water sector in China.

\subsubsection{Demand Side Management-Water Conservation and Public Participation}

In demand side management, water conservation and public participation were the main policies adopted during reform. Water conservation was officially written into the 2002 Water Law. New competency authorities, the Water Conservation Offices, were established centrally and locally. At the national level, the Water Conservation Office carries out water conservation works under the authority of the MWR while the Water Conservation Offices at the city level are under the control of both the municipalities and the National Water Conservation Offices. Initially, water conservation was mainly achieved by improving efficiency in the industries. In August 2002, the National Water Conservation Office published "The Water Saving Plan (2001-2010)". This plan aimed to simultaneously stimulate water conservation actions in agriculture, industry and in domestic consumption by establishing systematic plans, constructing legal oversight mechanisms, disseminating water saving facilities, promoting water recycling and increasing water saving awareness among the citizens.

The "Water-Saving Society Construction" program was launched in 2002. The objective of this program is to establish comprehensive water conservation in the urban areas in China. Initially, ten experimental cities were chosen. The selection was based on the representation of local hydraulic and geographic conditions, development stage, urbanization level and population size. Following the positive impacts from this program in those ten cities, the "Water-Saving Society Construction" program was gradually spread to other cities in China. Over time, six batches of cities, a total of 63 cities and one county, have participated in this program (Table 3.2). In the last batch of cities, one county, Changxing County in Zhejiang 
province, was also included. This shows that the central government intends to spread the water-saving society construction to even larger areas.

Table 3.2: Water-saving demonstration construction projects in China

\begin{tabular}{ll}
\hline Year & The demonstration projects of water-saving cities \\
\hline 2002 & Beijing, Shanghai, Jinan, Qingdao, Dalian, Hangzhou, Xuzhou, Taiyuan, Zhengzhou, Tangshan \\
2005 & $\begin{array}{l}\text { Tianjin, Hefei, Haikou, Chengdu, Yangzhou, Shaoxing, Yantai, Weihai } \\
2007\end{array}$ \\
$\begin{array}{l}\text { Yinchuan, Ningbo, Guilin, Langfang, Weifuang, Rizhao, Dongying, Haiyang, Penglai, } \\
\text { Zhangjiagang, Kunshan }\end{array}$ \\
$\begin{array}{l}\text { Wuhan, Nanjing, Xiamen, Shenyang, Wuxi, Huangshan, Mianyang, Baoji, Wujiang, Jiaonan, } \\
2009\end{array}$ \\
$\begin{array}{l}\text { Shouguan } \\
\text { Suzhou, Zhenjiang, Jiangyin, Changshu, Taicang, Jiaxing, Zhoushan, Taian, Longkou, Wendeng, }\end{array}$ \\
$\begin{array}{l}\text { Jiyuan, Huangshi, Changde, Shenzhen, Guiyang, Kunming, Urumqi } \\
\text { Chizhou, Xuchang, Nanning, Beihai, Yixing, Anning, Changxing County }\end{array}$
\end{tabular}

Public participation is viewed as one of the most important elements in demand side water management. Water conservation is achieved through the water saving actions of individuals as behavior directly affects consumption levels. Therefore, the construction of a water-saving society depends on public participation, which is one of the main strategies highlighted by the government.

In China, public participation is stimulated at two levels: participation in decisionmaking related to water issues and participation in the implementation of policies. The implementation of the public participation policy was initialed in the beginning of the 1990s. China's Agenda 21 (the State Council, 1994) clearly stated that China should "develop and improve a consultative process for developing legislation and solicit opinions from the general public and inform the public regarding the adoption of those suggestions" and "enhance transparency in administration and decision-making and establish non-governmental consultative agencies and a public information network to enable the public and relevant non-governmental organizations to participate more effectively in the process of decision-making". Later, public participation was written into water laws as part of the standard process of decision-making, such as in the environmental impact assessment of construction projects and water pricing adjustments.

Individual behavior is activated by two types of motivations, intrinsic motivations and extrinsic motivations. Intrinsic motivation is motivation that is activated within a person whereas extrinsic motivation implies motivation inspired by fiscal incentives or social obligations (Berglund and Matti, 2006). In traditional economics and contemporary environmental policymaking, the latter set of motives is primarily acknowledged as determining pro-environmental behavior in individuals. However, the former is also important and could also lead to positive environmental actions.

In China, in addition to general fiscal incentives, the government tries to stimulate the formation of intrinsic motivations among its citizens for environmentally friendly actions, mainly through environmental education. Environmental educa- 
tion in China is carried out through general school education and disclosure and dissemination of environmental information. Water education is one of the most important parts of environmental education. The information disclosure system and public information network established in China to facilitate the dissemination of information includes the government and other institutions, such as water enterprises, NGOs and the media (Li et al., 2008). Water related information is produced in the form of reports, books and other tangible deliverables with the goal of promoting water saving awareness and opinions and attitudes among water users that can catalyze water saving behavior. According to some surveys ${ }^{15}$, an increase in environmental awareness among Chinese citizens is being observed, which could be viewed as a positive result of the implementation of public participation policies.

As a result, water conservation policies and public participation policies have achieved some positive results. In general, the total water consumption in urban areas in China has stabilized in the past two decades. When consumption is measured at the individual level, we can see a continuous drop since 2000; citizens are more aware of the importance of environmental protection and water conservation. Public participation has become common in some types of environmental decision making and implementation, such as water pricing adjustment hearings, but it generally still needs to be systematically reinforced. There is no doubt that the implementation of water conservation policies and public participation policies has already achieved positive results, but efforts are still needed to further increase public participation and stimulate water conservation.

\subsection{Conclusion}

Urban water management reform in China is comprehensive and comprised of institutional construction and restructuring, legal system establishment and improvement, and market-oriented reforms. In the past three decades, urban water management has shifted from supply side management to simultaneous supply side and demand side management and toward the development of integrated urban water management in China. The stages of development that China has gone through have clearly defined the necessity of emphasizing both supply side management and demand side management.

Reform has injected new vitality into the Chinese water sector. The restructured institutions, the established water legal system, the constructed water market, the active presence of the foreign private sector, the successfully self-restructured state-owned water enterprises, the rapidly growing domestic private sectors, and the increasing public environmental awareness and public participation all show the successful results of urban water management reform over the past three decades. This success is largely attributable to strong government interventions and timely policy adjustments and regulations during the reform. Water is both a

${ }^{15}$ For more details about the survey, please read the Chapter 5 in this thesis. 
public and an economic good, so the combination of market principles and government intervention could take full advantage of the market while avoiding market failures.

Of course, this does not mean that the reform of the urban water sector in China is perfect. In fact, there are still many areas for improvement, such as the lack of a well-established legal framework, the lack of effective regulatory measures and relatively weak wastewater management. Compared to developed countries, the water consumption per GDP is still much higher, so further efforts are needed to achieve sustainable urban water management in China.

Over the next two decades, China will face a continuously increasing population, urbanization, industrial development and climate change, which will continue to challenge water management in China, especially in urban areas. Sustainable urban water management is crucial for water authorities in China. At the beginning of the 2010s, the Chinese government took another step toward urban water management reform and created a new water management plan for the next two decades, "Water resources plan 2011-2030", in which water saving, water recycling and integrated water management are continuously emphasized. 


\section{CHAPTER 4}

\section{The Productivity Change in the Privatized Water Sector in China: Technical Change, Efficiency Change and Scale Efficiency Change 1999-2006}





\subsection{Introduction}

In 1989, the Conservative Party led by Margaret Thatcher privatized the British water industry, which initiated a new era of water management worldwide. The privatization policies adopted by the Thatcher administration were meant to solve the water sector's growing problems in the 1970s, such as heavy financial burdens on the government, low productivity and high inefficiency. This approach soon spread all over the world, as it presented a solution to the universal problems in water sectors; it was first adopted by other developed countries, and then it was adopted by the developing world.

Internationally, privatizing water sectors became prevalent in the developing world during the beginning of the 1990s; this development followed the privatization movement in developed countries and the advocacy of international organizations such as the World Bank. In developing countries, privatizing the water sector is characterized by the massive participation of multinational water firms. After two decades of trials, privatization in water sectors has failed to achieve the desired goals in many developing countries, such as the well-known case in Bolivia. Due to the massive opposition movements in those countries, international water companies had pulled out of those markets by the end of the 1990s. Therefore, many people have argued that privatization as a solution to publicly managed water sectors' problems does not work in the developing-world context. If that argument is correct, we would expect both a complete withdrawal of international water companies from developing countries and the return of state-owned water firms in general.

However, while we have observed the substantial withdrawal of international water companies from many developing countries, we have also viewed the persistence of water privatization and multinational water firms' participation in other developing countries such as China. This phenomenon implies that firstly, the privatized Chinese water market is attractive to water MNCs (Multinational corporations) despite their failures in many other developing countries; secondly, multinational participation contributes to the sector's development. Therefore, the government and many citizens advocate the water sector's privatization and the participation of MNCs in China. In this chapter, we give close scrutiny to the Chinese privatized water sector and examine the privatization reforms' effects on the water sector in the urban areas of China.

Traditionally, the Chinese water sector was managed and regulated by local municipalities with the support of the central government in urban areas. Water was supplied to domestic customers and a few industrial customers as a purely public good either without charge (during 1949-1964) or with a very low charge (during 1965-1992). In these two periods, China's water sector survived with high subsides from the central government and local municipalities. However, outmoded technology, the redundancy of employees, poor management and the lack of effective regulations led to low productivity and inefficiency in the Chinese water 
sector. The rapid economic growth triggered by the economic reforms and opening-up policies that have been implemented in China since 1978 has significantly increased the water demand in urban areas, which further exacerbates the problems in the water sector. Although the dramatically increased water demand requires substantial capital investment in the water sector, which is hardly fulfilled by the government alone, the water environment deterioration caused by industrial pollution has largely reduced the quality of raw water, which has greatly increased water production costs and the difficulty of managing the water sector. As a result, since the end of the 1990s, the water supply became an encumbrance of the social-economic development in many places in China, especially in urban areas.

Following the international trends, privatization was proposed as the solution to the failure of the state-owned and managed water sector in China with the aims of releasing public financial resources from the water sector, achieving higher efficiency in water production and allocation, updating outmoded technologies, establishing a water market, constructing legal and regulatory systems for water and strengthening the role of the private sector in the economy. The privatization of the water sector in China was marked by the first foreign direct investment by SUEZ France in the Tanzhou Water Supply Project in Zhongshan, Guangdong province in 1992. After two decades of development, it is undoubted that the private sector is already deeply embedded in the Chinese water industry.

The privatization of the Chinese water sector has been characterized by massive foreign investment from multinational water firms and public-private partnership (PPP) involvement, which is similar to the privatized water sector in many other developing countries. However, China's water privatization is different in that it is also accompanied by the rise of local private enterprises and state-owned water firms' reforms. The complexity of ownerships in China's water sector provides us a great opportunity to compare different ownerships under the same institutional conditions in the developing-world context.

The assessments of the effects of privatization that are associated with ownership in the water sector are receiving increasing attention. The theoretical foundation of privatization rests on neo-liberalism, welfare economics theory, principal-agent theory, property rights theory and public choice theory. Generally, these theories argue that public failures are mainly caused by the lack of incentives and selfinterest seeking, which may lead to larger budgets and lower performance among state-owned water firms. Hence, privatization is proposed as the solution to these problems in the state-owned water sector. However, it does not imply that the privately owned water sector is always better off. The rent-seeking behavior and monopoly power of privately owned firms may also lead to the failure of watersector privatization reforms. Hence, market conditions and regulations play very important roles in the privatized water sector. We argue that the success of water privatization reforms largely depends on the capability and effectiveness of governments with respect to managing the water sector. 
Empirically, there are two groups of studies focusing on efficiency achievement through privatization reforms in the water sector. Whereas the first group of works aims to compare the efficiency difference between publicly and privately owned water utilities, the second group of works tries to examine the effects of privatization on productivity and efficiency. Earlier studies mainly focused on the performance achieved through privatization and the efficiency differences between public and private water providers in developed countries, such as the UK, the US, France and Australia. Some recent studies also try to investigate the effects of water privatization in the developing world, for instance, Uruguay, Argentina and African countries (Idelovitch and Ringskog, 1995; Estache and Trujillo, 2003; Mugisha, 2007; Kirkpatrick et al., 2006). The effects of ownership on productivity growth in the water sector is inconclusive in the empirical literature: while some researchers believe that privatization reforms is the solution to problems in water sectors, other researchers have found that state-owned water firms are equally efficient or even more efficient than privately owned water firms (Bhattacharyya et al., 1995; Garcia-Sanchez, 2006; Estache and Rossi, 2002, etc.). Therefore, the latter group has questioned the effectiveness of privatization as the solution to the inefficiency of water sectors.

As the largest developing economy, the water sector's privatization reform in China receives considerable attention. The majority of the studies focusing on the effects of privatization on the Chinese water sector were conducted with qualitative methods (Yu and Danqing, 2005; Zhong et al., 2008). There have been limited studies in the field based on quantitative methods due to the data accessibility issue. To our knowledge, there are only four quantitative studies discussing the effects of privatization on the water sector in China (Hu et al., 2006; Jiang, 2009; Jiang and Zheng, 2010; Wang et al., 2011). Among these four studies, only Jiang and Zheng's work (2010) was based on firm-level panel data. However, this study only included firms' financial information, which miss-specified the water sector's characteristics and potentially led to inaccurate results.

In this chapter, we estimate the effects of the Chinese water sector's privatization reforms based on firm-level panel data from 1999-2006. By applying a translog stochastic frontier production function and a parametric generalized Malmquist productivity index, we identify the production frontier of the water sector and examine its productivity change during the privatization reforms in China. Our work provides further evidence to the debate on privatization's impacts on the water sectors' performances in developing countries. The technical change, efficiency change and scale efficiency change will be examined by decomposing the parametric generalized Malmquist productivity index. Furthermore, the ownership discrepancy is identified based on the group mean values of the productivity growth and decomposition factors.

Our results show that water-sector privatization reforms accompanied by significant policy interventions in China have had positive influences on the water sector. The persistence participation of foreign water firms and the rapid increase of domestic privately-owned water firms have greatly contributed to the performance 
improvements of the Chinese water sector. Furthermore, both the central government and local municipalities actively adjust their roles in the water sector by transforming themselves from operators and managers to supervisors and regulators. While some old policies are abandoned, a series of new regulations and policies are designed and implemented in the water sector. All of the regulations and policies are adjusted over time according to the sector's development. It is beyond doubt that all of the efforts made by the central government and municipalities have greatly contributed to the successful water privatization reforms in China. As the world's largest developing economy, the Chinese experiences of water sector reform could provide useful information for other developing countries with respect to water management. Our work potentially contributes to the empirical literature, as it is the first study that quantitatively investigates the privatization reforms of the Chinese water sector at the firm level.

This chapter is organized as follows: in the following section, we review the relevant theoretical and empirical literature to our study, and in section 3, we describe the methodology adopted in this study, namely, the translog stochastic frontier production function and the parametric generalized Malmquist productivity index. In section 4, we present detailed information about the panel data and variables used in this chapter. Section 5 presents our empirical results, and in section 6, we discuss the relevant policy implications of these results. Our conclusions are presented in section 7.

\subsection{Literature Review}

\subsubsection{The Theoretical Background of Privatization and Productivity Improvement}

As a political strategy, privatization is advocated as a solution to the low productivity and efficiency of public firms in delivering water service. This idea is largely situated within the set of "neo-liberal" reforms, which sponsor economic liberalization, free trade, open markets, privatization, deregulation and decreasing the size of the public sector while increasing the role of the private sector (Robison and Hewison, 2005). In the context of the water sector, the objectives of privatization are 1) achieving higher efficiency in the allocation and production of water, 2) improving the financial capabilities of governments, 3) strengthening the role of the private sector in the economy and 4) releasing financial resources to be used in other sectors (Idelovitch and Ringskog, 1995; Sheshinski and Lopez-Calva, 2003).

Under welfare economics theory, privatization has the advantage of efficiency enhancement through competitive markets. However, this outcome is based on strong assumptions of a Pareto optimal competitive equilibrium. According to these assumptions, there is no externality in production and consumption, the good is not a public good, there is a non-monopolistic market structure and the information cost is low. If any of these assumptions do not hold, the environment is identified as market failure, which requires government intervention. Hence, the justification for privatization is less compelling in markets for public goods or 
natural monopolies where competitive considerations are weaker, such as the water sector. As a result, it seems that public ownership would eliminate private failures and provide better services in the water sector. This belief was the reason why governments took over their countries' water sectors in the 18th century. However, a state-owned water utility relies on the assumption that there is no government failure, which largely depends on the capability and transparency of the government. Unfortunately, on many occasions, and especially among developing countries, the national government has lacked the ability to accomplish the desired goals, such as maximizing social welfare and achieving high efficiency. Thus, the failure of state-owned water utilities in many countries was the result of government failure.

Based on the principal-agent theory and the property rights theory, the efforts of managers in state-owned utilities are hard to monitor, and due to the lack of appropriate incentives, they may not be doing their best to keep costs down or maintain high productivity. Under public ownership, those who control water firms (politicians and senior bureaucrats) have little personal incentive to improve the performance of these firms, as they would not necessarily benefit from doing so. In contrast, privately managed water firms can provide incentives to managers to ensure the firms are profitable (Alchian, 1965; Demsetz, 1967; De Alessi, 1983; Asher et al., 2005). Therefore, privatization is still desired if government-owned firms cannot provide satisfactory services. The impact of privatization will depend on the strength of the markets within the economies, the regulations and the existing private sectors.

According to public choice theory, individual actors in the market are assumed to make rational choices based on self-interest and utility maximization, which implies that private sector entities pursue profit maximizations rather than social welfare maximizations. Therefore, as public choice theorists argue, whereas such behavior in the private market would lead to an optimal consequence, the result is usually the opposite in public sectors (Starr, 1988). Public servants may act in their own self-interest, which may mean larger budgets and low performance. In the case of privately owned firms, tighter budgets and enhanced accountability diminish the scope for managerial discretion. However, the rent-seeking behavior of private firms will also lower the performance of the private sector, which should be effectively constrained by the government. If the government does not have the ability or desire to regulate the private sector, the privatization of state-owned utilities will not lead to the desired goals of privatization reforms, such as efficiency improvements and productivity increases.

The implications of these four alternative perspectives on the ownership question are straightforward. In general, the four important theoretical foundations of privatization share the common view that privately owned water utilities have better performance than state-owned ones under the premises of a well structured market and effective regulatory policies (Vickers \& Yarrow, 1989). If the private sector is not well regulated, merely privatizing the water sector and opening up the water market will most likely not lead to enhanced productivity. Hence, we argue 
that the effectiveness of water sector privatization largely relies on the construction of a water market, ensuring effective market competition and providing good regulations. The outcomes of water privatization reforms differ across countries, and they depend largely on governments' capacities to regulate and monitor their water sectors and construct water markets. It is clear that regulations play important roles in a market-oriented water sector.

\subsubsection{The Mixed Results of Empirical Studies}

Empirically, there is a substantial amount of research concerned with identifying the ownership's effects on efficiency changes and productivity growth in reformed water sectors. In particular, economists have been interested in determining whether changes from public to private ownership can be expected to lead to improved performance or have been observed to do so. In this section, we review the empirical studies examining this topic from two complementary perspectives: whether state-owned water firms' performance is generally worse than comparable private ones and whether there is evidence that privatizing water sectors (either entirely or in part) improves their performance.

In terms of the first group of studies, researchers have examined the argument that privately owned water firms are relatively more efficient than state-owned water firms. Mixed results were found in the empirical literature and no consensus exists. Earlier studies examined the link between ownership and performance by estimating an aggregate cost function for water firms, which usually included a dummy variable to test for ownership-based effects. Morgan (1977) and Crain and Zardkoohi (1978) found that the costs of privately owned water firms were lower than the costs of state-owned ones. Conversely, Bruggink (1982), Feigenbaum and Teeples (1983) and Teeples and Glyer (1987) found that state-owned water firms have lower costs. One of the most important drawbacks of these studies is that they assumed water firms have cost-minimizing behavior, which is not an appropriate assumption for the water sector. To address this problem, some studies adopted new measurement techniques to investigate water-sector efficiency differences, such as frontier approaches. Frontier approaches allow researchers to relax the cost-minimizing assumption, which is more suitable for investigating water sectors. Lynk (1993) adopted stochastic cost frontier models to compare the efficiencies between privately owned water firms and state-owned ones in the UK, and he concluded that privately owned firms were more efficient. By investigating 190 public and 31 private urban water utilities in 1992, Bhattacharyya et al. (1995) found that privately owned water firms are more efficient than their state-owned competitors in the US when the scale of operation was small, and these authors used stochastic cost frontier models. Using cross-sectional data from 76 water utilities in African countries, Kirkpatrick et al. (2006) found that privately owned water firms are more efficient than state-owned ones. Applying SFA econometric methods on panel data that contained 15 water and sewage firms during 20002006, Mugisha (2007) found that public-private partnership (PPP) had positive effects on the growth of the sector in Uganda. 
The opponents of privatization point to successful examples of public water systems and on research showing that private sector alternatives are not necessarily more efficient and are often much more expensive for users than well-managed public sector systems. By examining the cost behavior of 225 public and 32 private water utilities using data obtained from the 1992 survey of the water industry conducted by the American Water Works Association, Bhattacharyya, Parker, and Raffiee (1994) found that although state-owned water utilities were more efficient, they were more widely dispersed between the best and worst practices. After conducting a study on 21 African water utilities for the period 1995-1997, Estache and Kouassi (2002) found that state-owned water firms are more efficient than their privately owned competitors. Estache and Rossi (2002) did not find significant efficiency differences between privately owned and state-owned water firms in the Asian and Pacific regions by investigating 1995 survey data from the Asia Development Bank. In addition, Peda et al. (2013) studied 43 water firms in Estonia, which serve $68 \%$ of the Estonian population, and they did not find significant efficiency differences among different ownerships. Similar results have also been found by Garcia-Sanchez (2006), who studied 24 Spanish municipalities (and their water utilities) in 1999.

Instead of comparing state-owned and privately owned water utilities' efficiency, the second group of researchers focuses on the efficiency and productivity change of water utilities affected by privatization. Using a cost function and TFP measures, Saal and Parker $(2000,2001)$ found that privatization had no impact on the total factor productivity. In another work, together with Weyman-Jones (2007) they investigated the privatized English and Welsh water and sewerage industry during 1985-2000. They concluded that productivity growth is mainly achieved through technical change after privatization. And declines in productivity are attributable to efficiency losses, as privately owned water firms appear to have struggled to keep up with technical advances. Based on panel data of four Argentinean provinces from 1992 to 2001, Estache and Trujillo (2003) found that privatization had positive influences on the productivity growth of water firms. Gassner, Popov, and Pushak (2009) examined 977 water utilities in 48 countries from 1980 to 2005 using econometric techniques, and they showed that privatization with publicprivate partnerships in water services led to improvement in the sectors' performances.

As reviewed above, controversial results could be found in the literature. We argue that the mixed results of empirical studies in the literature of ownership and productivity achievement could be caused by 1) using poor data; 2) using an inappropriate production function for the water sector; 3) not controlling for exogenous factors; 4) adopting an unsuitable methodology; 5) ignoring market conditions and regulations; and 6) overlooking geographical and historical differences.

There have been limited studies focusing on the water sector's efficiency and the productivity changes caused by the privatization reforms in China. Based on firm- 
level financial panel data during 1998-2007 in China, Jiang and Zheng (2010) found that the financial performance of the Chinese water sector was improved by the privatization reforms. In this study, Jiang and Zheng adopted a production function with income as an output to describe the water sector, which we argue is an inappropriate specification for it. Moreover, they ignored the differences between domestic privately owned water firms and foreign-owned water firms, which might have led to a biased result. Wang and his coauthors (2011) used citylevel panel data obtained during 1998-2008 to examine the effects of privatization on the water sector in China. They used an economic variable (income), social variables (the population density and the urban population), and a private/public dummy to test the water sector's productivity improvement in 35 major cities in China. These authors found that although privatization and the emergence of a foreign private water sector have had positive effects on the water sector's performance, the domestic private sector does not contribute to this performance improvement. These authors argued that this problem is due to the limitations of the regulatory capability of local governments, the profit-pursuing character of the private sector and the monopoly power of increasing prices rather than reducing costs to pursue economic goals. The main drawback of this study is: this study was based on city-level aggregation data and assumed that all of the water firms in a city share the same public-private partnership condition and productivity. Obviously, this is an inappropriate assumption. We argue that the aggregation at the city level was a questionable treatment in this study.

\subsection{Methodology}

In this study, a translog stochastic frontier production function and a parametric generalized Malmquist productivity index are used to examine the productivity evolution of the Chinese water sector during the period 1999-2006. This methodology allows us to identify the sector's frontier and distinguish the different contributions of technical efficiency changes, technical changes and scale efficiency changes to the productivity changes of water firms.

In this study, the Chinese water sector is specified as a single output production technology and estimated with a translog stochastic frontier production function. We select the volume of delivered water as the output of our production function; this choice is based on the Chinese water sector's characteristics and the data availability. In China, the water sector experienced rapid growth during 1999-2006, which was mainly caused by the urbanization and population expansion in urban areas. In this period, supplying sufficient water to industries and citizens were the main objectives of the Chinese water sector, despite the continuously worsening quality of raw water in many places in China. Hence, the selection of the delivered water's volume as the single output in our stochastic frontier function accurately represents the Chinese water sector's productivity evolution during 1999-2006.

In the literature, the cost frontier function and the input distance function are the two main approaches employed in examining a water sector's efficiency. The cost 
frontier function requires the cost information of all inputs, which is not available in our dataset. The input distance function has been proposed as a solution to the multi-input and multi-output production technologies imposed with many restrictions that are also unsuitable for our study. As a result, the translog stochastic frontier production function is the most appropriate for our study, as it can accurately describe the characteristics of the Chinese water sector and examine its efficiency.

Furthermore, we adopt the Parametric Generalized Malmquist productivity index (PGMPI) (Orea, 2002; Coelli et al., 2005) to measure the productivity growth of the whole water sector in China. By relaxing the assumption of constant returns to scale in the Malmquist productivity index, the Parametric Generalized Malmquist productivity index controls for the contributions of scale economies to the productivity change. Therefore, the Parametric Generalized Malmquist productivity index is an accurate measure of purely technical efficiency changes (catching up), technical changes (frontier shifts) and scale efficiency changes. Cave, Christensen and Diewert (1982) showed that for translog production structures, a Tornqvist productivity index was equivalent to the geometric mean of two Malmquist productivity indexes after accounting for a scale factor. This result has significant implications, as it allows the calculation of a Total Factor Productivity (TFP) growth index without price data. This index is widely used for examining the productivity growth in utility sectors. Thus, our choice to employ a translog stochastic frontier production function with a Parametric Generalized Malmquist productivity index is suitable for exploring the productivity change of the Chinese water sector in the observation period.

\subsubsection{The Translog Stochastic Frontier Production Function}

A translog stochastic frontier production function model with non-neutral technical change is adopted in this study. Compared with other forms, translog is a flexible functional form that approximates any twice-differentiable function without imposing any a priori restrictions on the production technology (Chambers, 1988; Lovell et al., 1994; Coelli, 2003; Coelli et al., 2005). The stochastic frontier was original proposed by Aigner, Lovell and Schmidt (1977) and Meeusen and Van den Broeck (1977), and it assumes that deviations from the best practice frontier might be due to both inefficiency and other random factors. During the last two decades, some authors have suggested different methods to test whether some portions of inefficiency can be systematically explained either with a two-step approach or with a one-step approach (Battese and Coelli, 1995). The two-step approach requires two-step estimations in sequence: the first step is to estimate a stochastic frontier model, and the second step is to evaluate the relationship between the estimated inefficiency variable from the first step and its determinant variable. It has long been recognized that this two-step approach will bias the results due to the misspecification of the first step's function model. The solution to this bias problem is a one-step procedure in which the relationships among the inputs, outputs, inefficiency and inefficiency determinants are all estimated in one 
stage. In our study, we adopt the one-step approach to estimate the production of the Chinese water sector.

We assume that the technology used in the water sector can be represented by the following translog stochastic frontier production function model:

$$
\begin{aligned}
& \operatorname{lny}_{\mathrm{it}}=\alpha_{\mathrm{i}}+\sum_{\mathrm{m}=1}^{\mathrm{M}} \alpha_{\mathrm{m}} \ln \mathrm{x}_{\mathrm{mit}}+\frac{1}{2} \sum_{\mathrm{m}=1}^{\mathrm{M}} \sum_{\mathrm{n}=1}^{\mathrm{M}} \alpha_{\mathrm{mn}} \ln \mathrm{x}_{\mathrm{mit}} \ln \mathrm{x}_{\mathrm{nit}}+\lambda \mathrm{t}+\frac{1}{2} \lambda_{11} \mathrm{t}^{2}+ \\
& \sum_{\mathrm{m}=1}^{\mathrm{M}} \lambda_{\mathrm{m}} \ln \mathrm{x}_{\mathrm{mit}} \mathrm{t}+\mathrm{v}_{\mathrm{it}}-\mathrm{u}_{\mathrm{it}} \quad \mathrm{i}=1,2, \ldots, \mathrm{N}
\end{aligned}
$$

where $y_{i t}$ denotes the volume of water delivered by firm $i$ at time $t$. The vector of variables $\mathrm{x}_{\mathrm{mit}}$ is defined as $\left[\mathrm{x}_{1 \mathrm{it}}, \mathrm{x}_{2 \mathrm{it}}, \mathrm{x}_{3 \mathrm{it}}\right]$, which denotes the three inputs used in the production, namely, the fixed physical capital stock, the intermediated inputs and the number of workers in the labor force. In addition, $v_{i t}$ represents the random error; therefore, it is assumed to be independently and identically distributed. Lastly, $\mathrm{u}_{\mathrm{it}}$ is a non-negative stochastic variable that measures the inefficiency.

In this study, we consider the time-varying inefficiency model in which (naturally) the inefficiency component varies over time. Following Wang and Ho's approach (2010), the inefficiency component $u_{i t}$ is expressed as the production of a positive function $h_{i t}$ and an independent distribution that is truncated at zero $u_{i}^{*}$. The function $h_{i t}$ is an exponential function of non-stochastic inefficiency determinants $\mathrm{z}_{\mathrm{it}}$. This model exhibits the "scaling property" whereby depending on $\mathrm{z}_{\mathrm{it}}$, the onesided inefficiency term $u_{i t}$ equals a scaling function $h_{i t}$ multiplied by a one-sided error distributed independently of $z_{i t}$. With this property, the shape of the underlying inefficiency distribution is the same for all individuals, but its scale is stretched or shrunk by observation-specific factors $\mathrm{z}_{\mathrm{it}}$. Moreover, the time-invariant specification of $u_{i}^{*}$ allows the inefficiency $u_{i t}$ to be correlated over time for a given individual (Wang and Schmidt, 2002; Alvarez et al., 2006; Wang and Ho, 2010).

$$
\begin{aligned}
& \mathrm{v}_{\mathrm{it}} \sim \mathrm{N}\left(0, \sigma_{\mathrm{v}}^{2}\right) \\
& u_{i t}=h_{i t} \cdot u_{i}^{*} \\
& h_{i t}=f\left(\delta z_{i t}\right)=\exp \left(\delta z_{i t}\right) \\
& u_{i t}=\exp \left(\delta z_{i t}\right) \cdot u_{i}^{*} \\
& u^{*} \sim N^{+}\left(0, \sigma_{u}^{2}\right)
\end{aligned}
$$

Traditionally, panel stochastic frontier models do not distinguish between unobserved individual heterogeneity and inefficiency. Thus, they force all time-invariant individual heterogeneity into the estimated inefficiency. To separate individual heterogeneity from inefficiency, fixed individual effects $\alpha_{i}$ are included in the model to capture any time-invariant cross-unit heterogeneity, which is proposed by Greene as the "true fixed-effect" stochastic frontier model (Greene, 2005a; Greene, $2005 b)$. However, as noted by Greene (2005b) and Saal, Parker and Weyman-Jones (2007), the inclusion of firm-specific fixed effects as dummies in a standard fixedeffect panel data model is associated with the incidental parameter problem. Indeed, this problem is even more significant when $\mathrm{T}$ is small. Therefore, this 
model is not appropriate for many empirical studies when the observation period is relatively short.

To address this problem, Wang and Ho (2010) proposed a different panel stochastic frontier model that has the true fixed-effect model specification and yet allows model transformations to be done while keeping the likelihood function tractable. By within-transformation, the sample mean of each panel is subtracted from every observation in the panel. Thus, the transformation removes the time-invariant individual effects from the model and avoids the problem of incidental parameters. In this model, the consistency can be obtained by $\mathrm{N} \rightarrow \infty$ even when the observation period $\mathrm{T}$ is relatively short, which are the normal conditions in empirical applications.

Moreover, the model specifies the inefficiency stochastic term $u_{i t}$ as the product of a positive function $h_{i t}$ and a positive random variable $u_{i}^{*}$. The positive function $h_{i}$ specified in equation (4) accommodates exogenous determinants $\left(z_{i t}\right)$ of the inefficiency, and furthermore, the specification of $u_{i}^{*}$ as $N^{+}\left(\mu, \sigma_{u}^{2}\right)$ allows the pretruncation mean of the inefficiency variable $\mu$ to be non-zero. Therefore, this model exhibits the scaling property such that depending on $z_{i t}$, the one-sided error term equals a scaling function $h_{i t}$ multiplied by a one-sided error that is distributed independently of $z_{i t}$. With this property, the shape of the underlying distribution of the inefficiency is the same for all individuals, but the scale of the distribution is stretched or shrunk by observation-specific factors $z_{i t}$. The time-invariant specification of $u_{i}^{*}$ allows the inefficiency term $u_{i t}$ to be correlated over time for a given individual. In addition, a special maximization routine is not required in this model.

As a result, our model has the advantages of successfully separating individual heterogeneity from the time-varying inefficiency components and solving the incidental parameter problem. Therefore, the model adopted in this study could effectively estimate the stochastic frontier production function of the water sector and investigate the inefficiency of water firms in China.

\subsubsection{The Parametric Generalized Malmquist Productivity Index (PGMPI)}

We identify productivity changes in the water sector using the Parametric Generalized Malmquist productivity index (Ray, 1999; Orea, 2002; Coelli et al., 2003; Coelli et al., 2005). For translog production structures, the Tornqvist productivity index is equivalent to the geometric mean of two Malmquist productivity indexes after accounting for a scale factor (Cave, Christensen and Diewert, 1982). This result has significant implications, as it allows the calculation of a Total Factor Productivity (TFP) growth index without price data. This index is widely used for examining the productivity growth in utility sectors.

The parametric generalized Malmquist productivity index generalizes the Malmquist productivity index by aggregating the growth in inputs using production elasticity shares rather than production elasticities as weights. Hence, this 
index satisfies four desirable properties of a total productivity index, namely, identity, monotonicity, separability and proportionality. After adopting parametric methods of decomposing a generalized Malmquist productivity index, the assumption of constant returns to scale is relaxed in the stochastic frontier production function. As a result, the parametric generalized Malmquist productivity index provides extra information on the scale efficiency changes, technical changes (frontier shifts) and technical efficiency changes (catching up).

Based on the translog stochastic frontier production function (1), we obtain the Parametric Generalized Malmquist productivity index:

$$
\begin{aligned}
\ln G M_{I}=\ln \left(\frac{T E_{i, t+1}}{T E_{i, t}}\right)+0.5\left[\left(\frac{\partial \ln y_{i, t+1}}{\partial t}\right)+\left(\frac{\partial \ln y_{i, t}}{\partial t}\right)\right] \\
+0.5 \sum_{m=1}^{M}\left[\left(S F_{i, t+1} \varepsilon_{m i, t+1}+S F_{i, t} \varepsilon_{m i, t}\right) *\left(\ln x_{m i, t+1}+\ln x_{m i, t}\right)\right]
\end{aligned}
$$

In equation (7), the first term on the right-hand side measures the technical efficiency change, the second term presents the technical change over time and the third term indicates the scale efficiency change over time. In addition, the technical efficiency measures each individual firm's distance from the sector frontier at each point in time, and the technical efficiency change measures the change in the value of the technical efficiency from one period to the next. Whereas the technical change captures the shift in technology between two periods, the scale efficiency change measures the contribution of scale economies to the productivity growth. When the sector exhibits non-constant returns to scale, any change of the scale will affect productivity; therefore, such changes should be considered in the overall productivity change. Hence, we can write:

$\mathrm{TFPC}=\mathrm{TEC}+\mathrm{TC}+\mathrm{SEC}$

The technical efficiency could be obtained from the estimation of equation (1). Therefore, we could obtain the technical efficiency change (TEC) as follows:

$\mathrm{TEC}=\ln \left(\frac{\mathrm{TE}_{\mathrm{i}, \mathrm{t}+1}}{\mathrm{TE}_{\mathrm{i}, \mathrm{t}}}\right)$

In addition, the technical change (TC) is measured as the mean of the technical changes obtained in two consecutive periods, which could be derived directly from the coefficients estimated for equation (1). 
$\mathrm{TC}=0.5\left[\left(\frac{\partial \ln \mathrm{y}_{\mathrm{i}, \mathrm{t}+1}}{\partial \mathrm{t}}\right)+\left(\frac{\partial \ln \mathrm{y}_{\mathrm{i}, \mathrm{t}}}{\partial \mathrm{t}}\right)\right]$

Finally, to calculate the scale efficiency change (SEC), both the production elasticity and scale factors are needed. These production elasticities could be obtained from the parameters estimated for equation (1) through the following expressions:

$\varepsilon_{\text {nit }}=\frac{\partial \ln y_{i t}}{\partial \ln x_{\text {nit }}}=\alpha_{\mathrm{n}}+\sum_{\mathrm{m}=1}^{\mathrm{M}} \alpha_{\mathrm{nm}} \ln \mathrm{x}_{\mathrm{mit}}+\lambda_{\mathrm{n}} \mathrm{t}$

The scale factor for each input at each data point is:

$\mathrm{SF}_{\mathrm{it}}=\frac{\varepsilon_{\mathrm{it}}+1}{\varepsilon_{\mathrm{it}}}$

where $\varepsilon_{i t}=\sum_{n=1}^{M} \varepsilon_{n i t}$ is the standard returns to scale elasticity. Thus, we obtain the scale efficiency change as follows:

$\mathrm{SEC}=0.5 \sum_{\mathrm{m}=1}^{\mathrm{M}}\left[\left(\mathrm{SF}_{\mathrm{i}, \mathrm{t}+1} \varepsilon_{\mathrm{mi}, \mathrm{t}+1}+\mathrm{SF}_{\mathrm{i}, \mathrm{t}} \varepsilon_{\mathrm{mi}, \mathrm{t}}\right) *\left(\ln \mathrm{x}_{\mathrm{mi}, \mathrm{t}+1}+\ln \mathrm{x}_{\mathrm{mi}, \mathrm{t}}\right)\right]$

\subsection{Data}

\subsubsection{Specification of the Data}

This study is based on panel data of Chinese water firms during 1999-2006, which is a sub-dataset of the Annual Survey of Industrial Enterprises Database constructed by the National Bureau of Statistics of China. In this panel data, the water sector is comprised of water supply firms and wastewater treatment and reuse firms. By 2002, the National Bureau of Statistics of China adjusted the National industries classification. Under the new classification, some municipal engineering management firms were sorted into the category of wastewater treatment and reuse firms. Due to this adjustment, the wastewater treatment and reuse category is not consistent. Therefore, in this study we do not consider any wastewater treatment firms. However, we argue that due to the natural connections between the water supply and wastewater treatment, the wastewater sector's performance and reform affect the performance of the water sector. In the literature, some researchers have examined the productivity growth rate of wastewater treatment and the water supply together but based on different production functions. Therefore, water firms and wastewater firms do not share the same frontier. Due to the data limitation, this issue is beyond the scope of this study. 
Table 4.1: The number of observations categorized with ownerships

\begin{tabular}{lcccc}
\hline Year & $\begin{array}{c}\text { State-owned } \\
\text { water firms }\end{array}$ & $\begin{array}{c}\text { Domestic privately } \\
\text { owned water firms }\end{array}$ & $\begin{array}{c}\text { Foreign-owned } \\
\text { water firms }\end{array}$ & Total \\
\hline 1999 & 1629 & 39 & 8 & 1676 \\
2000 & 1706 & 49 & 9 & 1764 \\
2001 & 1739 & 80 & 11 & 1830 \\
2002 & 1760 & 105 & 19 & 1884 \\
2003 & 1740 & 128 & 23 & 1891 \\
2004 & 1830 & 193 & 33 & 2056 \\
2005 & 1638 & 219 & 37 & 1894 \\
2006 & 1481 & 219 & 38 & 1738 \\
\hline
\end{tabular}

Three groups of ownership are distinguished in this study: (1) state-owned water firms, (2) domestic privately owned water firms, which are owned by the domestic private sector, and (3) foreign-owned water firms, which are mainly controlled by foreign investors. Table 4.1 provides detailed information regarding our dataset. Based on the National Economy Industry classification code, we adjust the water sector before and after 2002 and obtain consistent water-firm panel data. The term "water firms" encompasses those firms that carry out water production and are in the water supply business. Our panel dataset is an unbalanced panel dataset that consists of approximately 1850 water firms (the number was different from year to year, e.g., it was 1676 in 1999 and 2056 in 2004). Theoretically, this dataset covers almost all of the water firms with more than 20 employees in China ${ }^{16}$.

\subsubsection{Output Variables}

In the literature, the relationship between input and output in the water sector follows a production approach in which water utilities are viewed as producers of physical water output. Therefore, the volume of delivered water and the number of connected properties are two common measures of physical output in the water sector. Some researchers also considered the water's density (Bottasso and Conti, 2003; Fraquelli and Moiso, 2005) and quality (Saal and Parker, 2006) as output measures. Due to limited data availability, we use volume of delivered water as the output measure in our translog stochastic frontier production function.

Data for the delivered water volume could not be obtained directly from the Annual Survey of Industrial Enterprises Database. However, this database contains product sales revenue information, and in conjunction with the water price information we could estimate the volume of delivered water by each firm at each point in time.

In China, water utilities normally supply water both to residential and industrial customers in urban areas. These two groups of customers are charged differently in our observation period. Therefore, based on the proportion of water delivered to

${ }^{16}$ Based on the industrial identification, firms with fewer than 20 employees are identified as selfemployed businesses, which are not accounted for in our study. 
residential customers and industrial customers by each firm, we could calculate the unit water price for each individual firm and then calculate the real output. However, the proportions of delivered residential water and industrial water are not available for each individual firm in the observation period. At most, we could always obtain the provincial industrial and residential water supply ratio. Hence, we use this ratio to approximate the industrial/residential water consumption ratio for each firm. We assume that all of the water firms located in the same province deliver the same proportion of water to residential customers and industrial customers. Although this is a strong assumption, arguably it is reasonable one for this study. The proportion of water supplied to residential and industrial customers in a city is determined by the characteristics of the industry and its water resources. However, the characteristics of the industry are not exogenous to the natural environment. For example, there will not be a lot of heavy waterconsuming plants in a city where the natural water supply is limited. In other word, natural conditions to some extent determine the distribution of the industry. In an area of a typical province in China, the geographical, hydrological and meteorological conditions are similar. It is rare to observe two neighboring cities in a Chinese province have dramatically different water resources and endowment. Therefore, we argue that the proportions of water supplied to residential and industrial customers among different cities in the same province are similar. In addition, the best data we can find for this matter is aggregated at the provincial level. A reasonable approach is thus to assume the proportions of the cities within this province are largely identical.

Regarding the water price, we assume that cities located in one province have the same water price. This is a strong assumption, however, water price information of 36 major cities ${ }^{17}$ in China is the best available data we can find. Moreover, water price in China is decided by the municipalities, under the control of central government and provincial water authorities, which covers the cost of water production, the cost of wastewater collection and treatment, and water resource fee. Water resource fee is decided by the provincial government in China based on the resource condition. Water firms in the same province face similar water resources, therefore, the cost of production and water resource fee are alike. Due to the industrial cluster character of Chinese industrial planning and development, the wastewater compositions are similar too, therefore the cost of wastewater collection and treatment would also be similar. Thus, our assumption of the same water price for firms located in the same province is an acceptable approximation of reality. The water price data are mainly drawn from two resources: the Department of Prices of National Development and Reform Commission (NDRC) of China and the Statistical Yearbook of the Urban Water Supply. We match the water price information with the Annual Survey of Industrial Enterprises Database according to the six-digit location codes.

${ }^{17}$ These cities include 23 provincial capital cities, four municipalities and four important, large cities (Dalian, Qingdao, Ningbo and Shenzhen). 
Through the industrial/residential water production ratio, the industrial water price and the residential water price, we could calculate the unit price of each firm. We further divide the sales revenue by the unit water price and obtained the volume of water delivered by each firm. As a result, the volume of delivered water is used as the sole output of our translog stochastic frontier production function. This set of calculations is the best approximation we could make with the available information in this study.

\subsubsection{Input Variables}

In this work, we consider three types of input, namely, labor, fixed physical capital and intermediate inputs. The fixed physical capital stock, labor, and the operational cost are the common inputs considered in the water-sector production function. Labor is represented by the number of full-time employees in a firm, and the fixed physical capital stock is measured by annual average net value of fixed assets for production, which is obtained by deducting the depreciation over years from the original value of fixed assets for production. This calculation is a precise measure of the fixed physical capital stock in production. In addition to the three common inputs, we also consider the intermediate inputs, which are computed as the value of all of the intermediated inputs used in production, such as chemical goods and electricity. The intermediate inputs cover the main costs of daily operation.

All of the input data used in the study are drawn from the Annual Survey of Industrial Enterprises Database. The number of full-time employees is available in the Annual Survey of Industrial Enterprises Database. In addition, the annual average net value of the fixed assets for production is calculated as the product of the annual average net value of fixed assets and the ratio of the fixed assets for production to the total fixed assets. Both the fixed assets for production and the total-fixed-assets data are available in the database. We used the price indices of the investment of fixed assets ${ }^{18}$ as a deflator to calculate the deflated annual average net value of the fixed assets for production.

In the water sector, the cost of energy consumption generally accounts for $80-90 \%$ (it varies across firms) of the total intermediate input cost. The rest of the total cost is mainly spent on chemical goods. Hence, the purchasing price indices of intermediate goods in the water sector could be estimated with the purchasing price indices of fuels and power and the purchasing price indices of raw chemical materials, which are used as deflators of the intermediate input variables. Based on the water sector's characteristics, we assume that the purchasing price indices of intermediate goods for the water sector equals $85 \%$ of the purchasing price indices of fuels and power and $15 \%$ of the purchasing price indices of raw chemical materials. We obtain the deflated intermediate input cost, which equals the product of the intermediate input cost and the purchasing price indices of intermediate goods in the water sector.

${ }^{18}$ The price in 1999 is defined as 1. 


\subsubsection{Inefficiency Determinants}

In this study, five inefficiency determinants are identified in our model to capture the effects of exogenous factors on the inefficiency components at the firm level. Specifically, these determinants are the water population density $\left(\mathrm{z}_{1}\right)$, the proportion of water abstracted from surface water $\left(\mathrm{z}_{2}\right)$, a domestic private ownership dummy $\left(\mathrm{z}_{3}\right)$, a foreign ownership dummy $\left(\mathrm{z}_{4}\right)$ and an increasing block tariff policy dummy $\left(z_{5}\right)$. The selection of inefficiency determinants in our model is consistent with the inefficiency determinants' selections in the literature (Anwandter and Ozuna, 2002; Bottasso and Conti, 2003; Woodbury and Dollery, 2004; Erbetta and Cave, 2007; García-Sáncez, 2006; Saal and Parker, 2006; Saal et al., 2007; Da Silva e Souza et al., 2007; Renzetti and Dupont, 2009).

The water population density $\left(\mathrm{z}_{1}\right)$ is calculated as the ratio of the population provided with water and the length of the water distribution network in the water supply area; this variable captures the density of the water service area. In general, providing water to a denser area is cheaper per connection due to lower frequent maintenance and lower energy requirements. Therefore, we expect that with an increase of the water population density, the inefficiency will decrease.

The proportion of water abstracted from surface water $\left(\mathrm{z}_{2}\right)$ accounts for the substantial differences in raw water used by water firms in production, which is beyond managers' control and affects the costs of inputs. Normally, underground water requires greater pumping costs, which will lead to higher costs for intermediate inputs. Therefore, we expect that the proportion of water abstracted from the surface would have a negative relationship with the inefficiency components.

The ownership may affect the firm inefficiency, and it is one of the focuses of this study. We create two ownership dummy variables based on firm ownerships, namely, a domestic private ownership dummy $\left(\mathrm{z}_{3}\right)$ and a foreign ownership dummy $\left(\mathrm{z}_{4}\right)$. The domestic private ownership dummy $\left(\mathrm{z}_{3}\right)$ identifies the group of water firms owned by Chinese stakeholders or Chinese private owners, whereas the foreign ownership dummy $\left(\mathrm{z}_{4}\right)$ indicates the foreign-owned water firms operating in China.

We are interested in the policy effects with respect to inefficiency reductions. Therefore, in this study we include an increasing block tariff policy dummy $\left(\mathrm{z}_{5}\right)$ to capture the policy effects and control for regulation differences. The increasing block tariff policy refers to the policy designed and adopted to implement the increasing block tariff system. The first increasing block tariff system in China was implemented in Shenzhen, Guangdong province in 1990. Since then, many cities have adopted block tariff policies in their water sectors, as one of the most important policies in privatization reforms. At present, more than 80 cities have implemented the increasing block tariff in China, although different cities implemented this system at different times. We use dummy variables to capture the reform rates and degrees. The adoption of increasing block tariff system could be viewed as a sign of great efforts made by the water authorities to achieve efficient 
and effective water management in urban areas in China. Therefore, we may expect that proper implementation of an increasing block tariff system will lead to inefficiency reductions in the local water sector.

Data for the water population density and the amount of water abstracted from surface water are obtained from the China Statistical Yearbook (2000-2007) and the China Urban Construction Statistical Yearbook (1999-2006). Unfortunately, these two data are not available at the firm level; hence, we approximate them with mean values for cities. Although this approximation may reduce the accuracy of the captured heterogeneity among firms in the same city and province, we argue that our assumption is still reasonable and reliable, as firms located in the same city/urban area normally face similar water population density conditions and abstract water from similar resources. Thus, we believe that our approximation is acceptable for this study.

The ownership dummies are created based on the data from the Annual Survey of Industrial Enterprises Database constructed by the National Bureau of Statistics of China. The domestic private ownership dummy is 1 for all of the firms owned by private entities and 0 for the other firms. Similarly, the foreign ownership dummy is 1 for all of the firms owned by foreign investors and 0 for the other firms. The increasing block tariff policy dummy is obtained through literature reviews, and its value is 1 for firms located in an area that has implemented a block tariff policy and 0 otherwise. Table 4.2 lists the definitions of the variables used in this study.

Table 4.2: Definitions of the variables

\begin{tabular}{|c|c|c|}
\hline Variable & Variable name & Definition and note \\
\hline Output & $\begin{array}{l}\text { Volume of delivered } \\
\text { water }\end{array}$ & $\begin{array}{l}\text { Logarithm of the volume of water delivered from water } \\
\text { firms to customers (unit: kilotons) }\end{array}$ \\
\hline \multirow[t]{4}{*}{ Input } & Fixed physical capital & $\begin{array}{l}\text { Logarithm of the deflated fixed physical capital stocks for } \\
\text { production (unit: thousands of Yuan) }\end{array}$ \\
\hline & Intermediate inputs & $\begin{array}{l}\text { Logarithm of the deflated intermediate inputs (unit: } \\
\text { thousands of Yuan) }\end{array}$ \\
\hline & Number of employees & $\begin{array}{l}\text { Logarithm of the number of full-time equivalent } \\
\text { employees (unit: persons) }\end{array}$ \\
\hline & Time period & Time period (year-based $\mathrm{T}=1,2, \ldots, 8$ ) \\
\hline \multirow[t]{5}{*}{$\begin{array}{l}\text { Inefficiency } \\
\text { determinants }\end{array}$} & Water population density & $\begin{array}{l}\text { Ratio of the population provided with water and the length } \\
\text { of the water distribution network (unit: persons/meter) }\end{array}$ \\
\hline & $\begin{array}{l}\text { Proportion of water } \\
\text { abstracted from surface } \\
\text { water }\end{array}$ & $\begin{array}{l}\text { Percentage of surface water used in water production } \\
\text { (unit: \%) }\end{array}$ \\
\hline & $\begin{array}{l}\text { Domestic private } \\
\text { ownership dummy }\end{array}$ & Dummy for domestic privately owned firms \\
\hline & $\begin{array}{l}\text { Foreign ownership } \\
\text { dummy }\end{array}$ & Dummy for foreign-owned firms \\
\hline & $\begin{array}{l}\text { Increasing block tariff } \\
\text { policy dummy }\end{array}$ & $\begin{array}{l}\text { Dummy for an increasing block tariff policy } \\
\text { implementation }\end{array}$ \\
\hline
\end{tabular}


In Table 4.3, we present a statistical summary of all of the variables used in our translog stochastic frontier production function regression. The original data are treated in two steps. Firstly, all of the data are treated in deviations from their sample means. This procedure will facilitate the calculation of the Parametric Generalized Malmquist production index, as it provides the advantage that the estimated first-order parameters in the translog stochastic frontier production function can be directly interpreted as estimates of the production elasticities that are evaluated at the sample means. This treatment is only a simple change in units of measurement that does not change the underlying data. Secondly, we take the logarithm of all of the data obtained in the first step.

Table 4.3: Summary of the variables

\begin{tabular}{|c|c|c|c|c|c|}
\hline Variable & Observation & Mean & $\begin{array}{l}\text { Standard } \\
\text { Deviation }\end{array}$ & Minimum & Maximum \\
\hline Volume of delivered water & 14733 & 0.000 & 1.437 & -4.889 & 5.460 \\
\hline Fixed physical capital & 14733 & 0.000 & 1.671 & -8.040 & 6.448 \\
\hline Intermediate inputs & 14733 & 0.000 & 1.445 & -5.103 & 6.051 \\
\hline Number of employees & 14733 & 0.000 & 0.956 & -1.731 & 4.062 \\
\hline Fixed physical capital sqr. & 14733 & 1.395 & 2.186 & 0.000 & 32.32 \\
\hline Intermediate inputs sqr. & 14733 & 1.044 & 1.562 & 0.000 & 18.31 \\
\hline Number of employees sqr. & 14733 & 0.457 & 0.778 & 0.000 & 8.251 \\
\hline $\begin{array}{l}\text { Fixed physical capital * Intermediate } \\
\text { inputs }\end{array}$ & 14733 & 1.976 & 3.394 & -15.46 & 38.68 \\
\hline $\begin{array}{l}\text { Fixed physical capital * Number of } \\
\text { employees }\end{array}$ & 14733 & 1.050 & 2.317 & -3.315 & 23.73 \\
\hline $\begin{array}{l}\text { Intermediate inputs * Number of } \\
\text { employees }\end{array}$ & 14733 & 0.981 & 2.072 & -3.581 & 21.87 \\
\hline $\mathrm{T}$ & 14733 & 0.060 & 2.246 & -3.500 & 3.500 \\
\hline T sqr. & 14733 & 2.524 & 2.255 & 0.125 & 6.125 \\
\hline Fixed physical capital * Year & 14733 & 0.430 & 3.755 & -21.78 & 24.65 \\
\hline Number of employees * Year & 14733 & 0.242 & 3.262 & -20.07 & 21.00 \\
\hline Intermediate inputs * Year & 14733 & 0.029 & 2.164 & -13.54 & 14.00 \\
\hline Water population density & 14733 & 1.182 & 0.955 & 0.035 & 28.71 \\
\hline $\begin{array}{l}\text { Proportion of water abstracted from } \\
\text { surface water }\end{array}$ & 14733 & 59.24 & 37.63 & 0 & 100 \\
\hline Domestic private ownership dummy & 14733 & 0.070 & 0.255 & 0 & 1 \\
\hline Foreign ownership dummy & 14733 & 0.012 & 0.109 & 0 & 1 \\
\hline Increasing block tariff policy dummy & 14733 & 0.023 & 0.151 & 0 & 1 \\
\hline
\end{tabular}




\subsection{Empirical Results}

The correlation matrix of all of the variables is shown in Table 4.4. The empirical results for the estimation of Eq. (1) are presented in Table 4.5. From these results, we obtain the coefficients of each independent variable and the variances of the inefficiency terms. We could further calculate the technical efficiency score of each individual firm at each point of time in the observation period and the corresponding Malmquist productivity index values.

In this study, the inefficiency term $u_{i t}$ is expressed as a function of the inefficiency determinants' factors. The result shows that the coefficients of the water population density $\left(z_{1}\right)$ are negative and statistically significant at the $5 \%$ level, which implies that an increase in the water population density leads to a decrease in the inefficiency of the corresponding water firm. This result is consistent with previous empirical studies in the literature.

The variable for the proportion of water abstracted from surface water $\left(z_{2}\right)$ has similar effects on the inefficiency term, and its coefficient is also negative and statistically significant at the $5 \%$ level. Therefore, the higher the percentage of surface water used in water production, the lower the inefficiency, which is consistent with the literature.

The coefficients of the domestic private ownership dummy $\left(z_{3}\right)$, the foreign ownership dummy $\left(z_{4}\right)$ and the increasing block tariff policy dummy variable $\left(z_{5}\right)$ are negative, but none of them is statistically significant. This insignificance might be caused by the short observation period, as we would expect to find statistically significant results when data with larger $\mathrm{T}$ are available. 


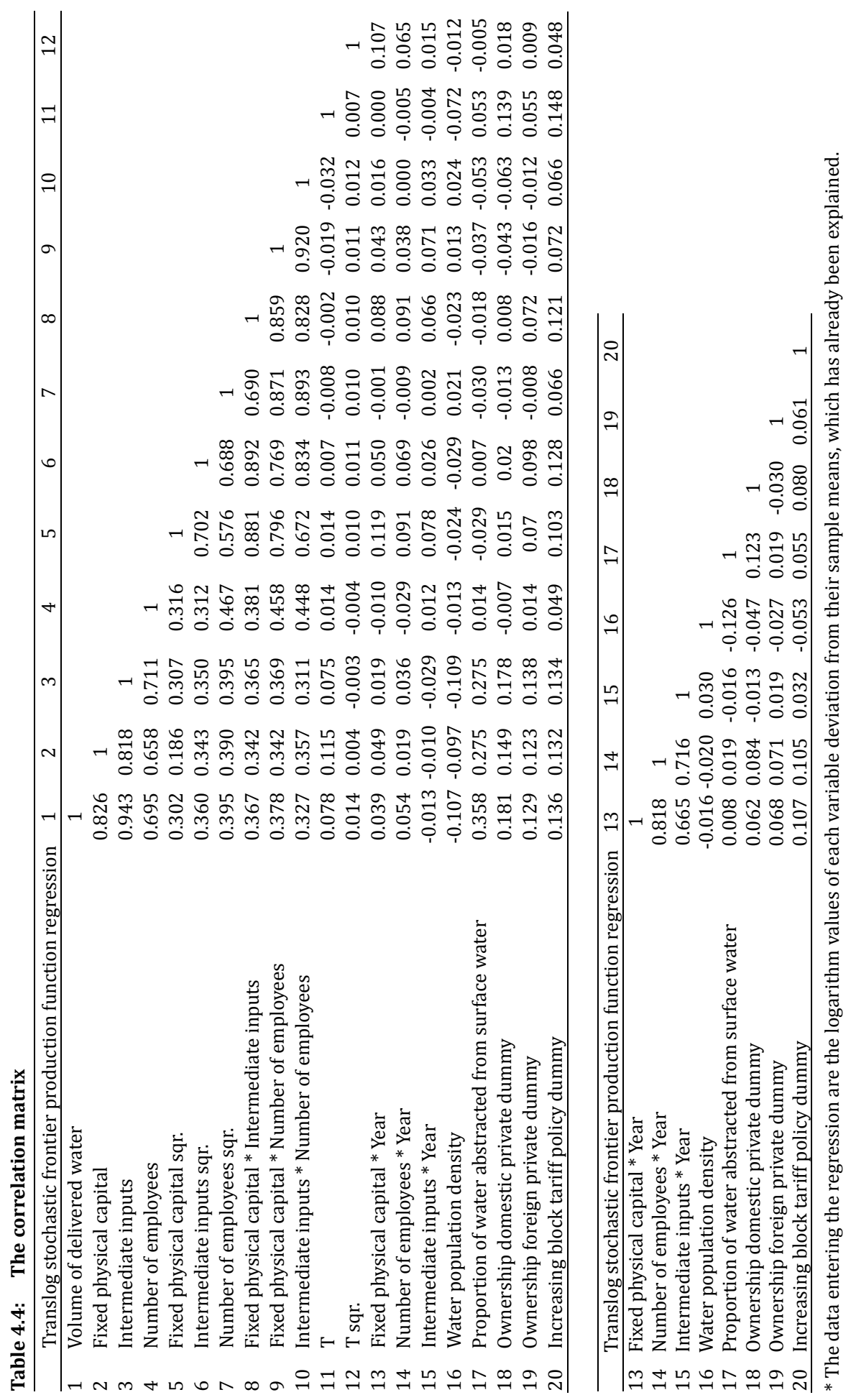




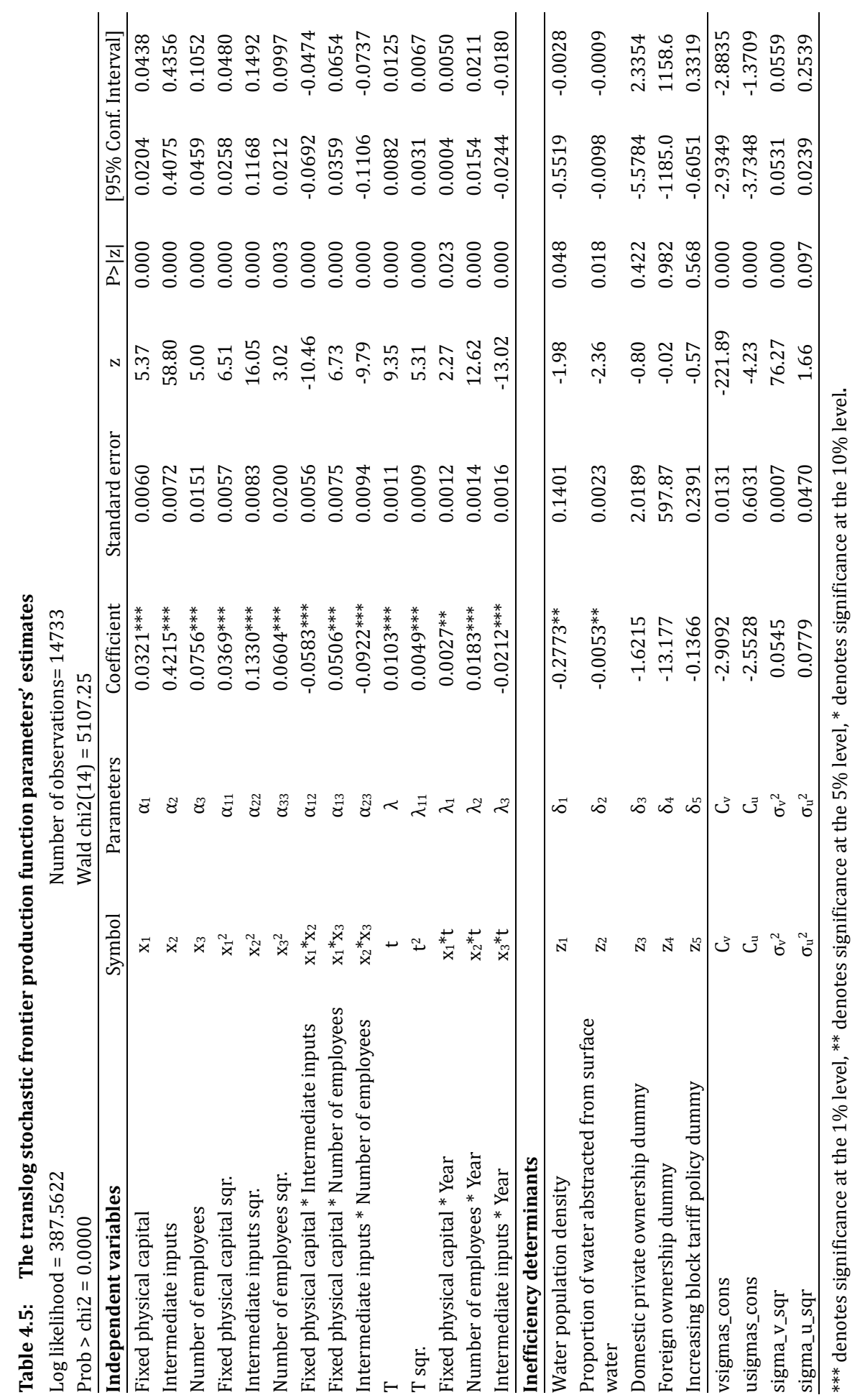


Based on the estimation of Eq. (1), we obtain the technical efficiency score of each individual firm at each point in time during 1999-2006. Table 4.6 presents the yearly mean values of the technical efficiency scores in different ownership forms. The result shows that foreign-owned water firms formed the frontier of the Chinese water sector in the whole observation period. Therefore, they were the most efficient water firms in the water sector in China during 1999-2006. Domestic privately owned water firms also had relatively high technical efficiency scores, which on average were approximately 0.98 for the observation period. Furthermore, the state-owned water firms had the lowest average technical efficiency score among the three ownership categories, which was approximately 0.89 . Thus, the overall technical efficiency score of the Chinese water sector increased over time in the sample period, though to a small degree, namely, from 0.894 in 1999 to 0.902 in 2006. This result implies that water privatization reforms and the participation of foreign-owned water firms in the Chinese water sector contributed to productivity improvement in this period, though the contribution is small.

Table 4.6: The technical efficiency scores

\begin{tabular}{lllll}
\hline Year & State-owned & Domestic privately owned & Foreign-owned & Total \\
\hline 1999 & 0.891 & 0.979 & 1.000 & 0.894 \\
2000 & 0.892 & 0.980 & 1.000 & 0.895 \\
2001 & 0.890 & 0.980 & 1.000 & 0.895 \\
2002 & 0.891 & 0.978 & 1.000 & 0.896 \\
2003 & 0.891 & 0.978 & 1.000 & 0.898 \\
2004 & 0.890 & 0.978 & 1.000 & 0.900 \\
2005 & 0.891 & 0.978 & 1.000 & 0.903 \\
2006 & 0.888 & 0.978 & 1.000 & 0.902 \\
\hline
\end{tabular}

To better understand the productivity changes in the Chinese water sector, based on the Parametric Generalized Malmquist productivity index methods we investigate the total factor productivity change of this sector. The Parametric Generalized Malmquist productivity index is further decomposed into the technical efficiency change, the technical change and the scale efficiency change. Table 4.7 shows the periodical mean values of the Parametric Generalized Malmquist productivity index. The technical efficiency scores are classified with ownership.

Table 4.7: The technical efficiency score and the Malmquist index decomposition based on ownership 1999-2006

\begin{tabular}{|c|c|c|c|c|c|}
\hline Ownership & $\begin{array}{l}\text { Technical } \\
\text { efficiency score }\end{array}$ & $\begin{array}{l}\text { Technical } \\
\text { change }\end{array}$ & $\begin{array}{l}\text { Technical } \\
\text { efficiency change }\end{array}$ & $\begin{array}{l}\text { Scale efficiency } \\
\text { change }\end{array}$ & $\begin{array}{l}\text { yTFPC } \\
\text { change }\end{array}$ \\
\hline State-owned & 0.891 & 0.858 & 0.082 & -1.038 & -0.098 \\
\hline $\begin{array}{l}\text { Domestic privately } \\
\text { owned }\end{array}$ & 0.978 & 3.627 & -0.672 & -0.908 & 2.048 \\
\hline Foreign-owned & 1.000 & 5.154 & -0.414 & -1.559 & 3.181 \\
\hline
\end{tabular}

Table 4.8 lists the yearly mean values of the Parametric Generalized Malmquist productivity index decomposition. In Tables 4.9, 4.10 and 4.11, we present the 
yearly mean values of the Parametric Generalized Malmquist productivity index decomposition for state-owned water firms, domestic privately owned water firms and foreign-owned water firms, respectively.

Table 4.8: A Malmquist index decomposition: a summary of the annual mean values of all water firms 1999-2006

\begin{tabular}{lllll}
\hline & TEC & TC & SEC & TFPC change \\
\hline $1999 / 2000$ & 0.064 & -0.754 & 0.125 & -0.566 \\
$2000 / 2001$ & -0.034 & -0.177 & -2.640 & -2.851 \\
$2001 / 2002$ & 0.089 & 0.461 & -3.739 & -3.189 \\
$2002 / 2003$ & 0.105 & 1.097 & -1.114 & 0.087 \\
$2003 / 2004$ & 0.031 & 1.582 & 1.333 & 2.946 \\
$2004 / 2005$ & 0.084 & 2.174 & 0.224 & 2.482 \\
$2005 / 2006$ & -0.137 & 2.834 & -1.560 & 1.137 \\
\hline
\end{tabular}

The technical change of the Chinese water sector increased over time in the sample period. The negative values of the technical change for the first two periods, namely, 1999/2000 and 2000/2001, were mainly caused by the negative values of the technical change in state-owned water firms, which we could see clearly from Table 4.9.

At initial stage of reforms, Chinese stated-owned water firms were dragged down by obsolete technologies and could not quickly update their old technologies. Although they were exposed to the new technology introduced by foreign-owned water firms, it was difficult for them to update their technology immediately. This difficulty led to the negative value of technical change at beginning of the water privatization reforms in China.

Table 4.9: A Malmquist index decomposition: a summary of the annual mean values of stateowned water firms 1999-2006

\begin{tabular}{lllll}
\hline & TEC & TC & SEC & TFPC change \\
\hline $1999 / 2000$ & 0.102 & -0.806 & 0.059 & -0.645 \\
$2000 / 2001$ & -0.020 & -0.251 & -2.662 & -2.933 \\
$2001 / 2002$ & 0.119 & 0.352 & -3.779 & -3.307 \\
$2002 / 2003$ & 0.190 & 0.951 & -0.939 & 0.202 \\
$2003 / 2004$ & 0.136 & 1.426 & 1.309 & 2.871 \\
$2004 / 2005$ & 0.124 & 1.887 & 0.273 & 2.284 \\
$2005 / 2006$ & -0.105 & 2.482 & -1.554 & 0.823 \\
\hline
\end{tabular}

Both domestic privately owned water firms and foreign-owned water firms exhibited a positive technical change during the period 1999-2006. In contrast to state-owned water firms, domestic privately owned firms could immediately adopt new technologies, as they did not have the burden of old machinery. Thus, they experienced a positive technical change since the beginning of the privatization reforms. 
Table 4.10: A Malmquist index decomposition: a summary of the annual mean values of domestic privately owned water firms 1999-2006

\begin{tabular}{lcccc}
\hline & TEC & TC & SEC & TFPC change \\
\hline $1999 / 2000$ & -1.418 & 0.860 & 1.277 & 0.718 \\
$2000 / 2001$ & -0.509 & 1.994 & -2.957 & -1.472 \\
$2001 / 2002$ & -0.599 & 2.469 & -2.206 & -0.337 \\
$2002 / 2003$ & -1.128 & 2.897 & -4.266 & -2.496 \\
$2003 / 2004$ & -1.484 & 3.426 & 0.934 & 2.876 \\
$2004 / 2005$ & -0.225 & 4.249 & 1.420 & 5.444 \\
$2005 / 2006$ & -0.374 & 4.734 & -1.771 & 2.589 \\
\hline
\end{tabular}

The foreign-owned water firms formed the production frontier of the water sector in the sample period, as they owned the most advanced technology and had the highest technical change. Overall, Chinese water privatization reforms with the presence of foreign-owned water firms had positive impacts on the technical change during the sample period, which led to dramatic upgrades of the technologies used in the sector.

As we already discussed above, foreign-owned firms had the highest technical efficiency score, which formed the sector frontier. In addition, whereas domestic privately owned firms were close to the frontier of the water sector and were only a small distance from it, state-owned water firms had the lowest technical efficiency score. The technical efficiency change was positive for state-owned water firms and negative for both domestic privately owned water firms and foreign-owned water firms. Although the technical efficiency change of state-owned water firms was positive, it was at the low rate of 0.082 . The negative value of technical efficiency change of foreign owned water firms might be caused by the changes of ownership in the observation period. The ownership of a few water firms were changed from state-owned to foreign owned during the observation period. Because the foreign owned firms were at the frontier, when they were transformed into state-owned firms, their technical efficiency dropped. Therefore, the technical efficiency change becomes a negative value.

Table 4.11: A Malmquist index decomposition: a summary of the annual mean values of foreign-owned water firms 1999-2006

\begin{tabular}{lcccc}
\hline & TEC & TC & SEC & TFPC change \\
\hline $1999 / 2000$ & -1.060 & 2.621 & 8.515 & 10.076 \\
$2000 / 2001$ & -0.349 & 3.459 & 4.416 & 7.527 \\
$2001 / 2002$ & 0.000 & 3.820 & -8.331 & -4.511 \\
$2002 / 2003$ & -1.093 & 4.775 & -0.103 & 3.579 \\
$2003 / 2004$ & -0.590 & 4.865 & 5.837 & 10.112 \\
$2004 / 2005$ & -0.275 & 5.560 & -9.372 & -4.086 \\
$2005 / 2006$ & -0.114 & 6.308 & -0.628 & 5.565 \\
\hline
\end{tabular}

Regarding the domestic privately owned water firms, there might be two reasons accounting for their negative technical efficiency change. The first reason is related to their sunk cost. In China, domestic privately owned water firms were mainly established in the later 1990s when the private investment was allowed to enter 
water sector. The newly established privately owned water firms incurred a large amount sunk costs when they started their business and made initial investments. This can lead to the negative technical efficiency change. The second reason is derived from Saal and Parker (2000)'s study in which they observed that the British firms which made efforts to boost their technical change can simultaneously suffered from negative technical efficiency change. The domestic privately owned water firms in China also achieved significant technical change during the observation period. However, similar to the British firms that Sall and Parker (2000) investigated, they did not catch up with the frontier of sector.

The scale efficiency changes fluctuated over time in the observation period, but were mostly negative. Based on the regression results shown in Table 4.5, we calculate the production elasticities for each input at each data point and the scale elasticities for each year in the observation period. The results show that all of the scale elasticities are positive and less than 1 , which implies that the Chinese water sector experienced decreasing returns to scale because scale efficiency changes capture the impact of changes in scale on the productivity growth. Therefore, the negative value of the overall scale efficiency change indicates diseconomies of scale characteristic of the Chinese water sector, which is consistent with the literature (Saal et al., 2007). Based on our data, it is clear that the Chinese water sector underwent an expansion process in the period from 1999 to 2006. The rapid increase of the investment in the water sector greatly contributes to its enlargement. In the water sector, building and testing water treatment plants normally takes 2-3 years, which will result in a time lag for large investments. Therefore, it is understandable to observe a negative value of the scale efficiency change when the Chinese water sector was greatly expanding. The higher the investment in the sector is, the greater the negative values of the scale efficiency change are. Furthermore, we prove our argument by examining the pairwise correlations between the scale efficiency change and three inputs, which shows that the scale efficiency change has negative correlations with all three of the inputs at the $1 \%$ level of significance.

The total factor productivity changes increased over time, as they were negative in the initial three years and became positive for rest of the period under study. The negative values of the first three years were mainly caused by the large negative values of the scale efficiency changes and the technical changes in the initial two years. In the remaining four years of the observation period, we find increasing productivity growth, which is mainly caused by the highly positive technical changes. These changes are the result of large-scale technological upgrades through technology embodied investment.

Table 4.12: Pairwise correlation coefficients and significances

\begin{tabular}{lccc}
\hline & $\begin{array}{c}\text { Fixed physical capital } \\
\text { change }\end{array}$ & $\begin{array}{c}\text { Intermediate inputs } \\
\text { change }\end{array}$ & $\begin{array}{c}\text { Number of employees } \\
\text { change }\end{array}$ \\
\hline $\begin{array}{l}\text { Scale efficiency } \\
\text { change }\end{array}$ & $-0.074^{* * *}$ & $-0.8602^{* * *}$ & $-0.0928^{* * *}$ \\
\hline
\end{tabular}

*** denotes significance at the $1 \%$ level 


\subsection{Conclusion}

In this study, we examine the productivity change of the Chinese water sector at the initial stage of the privatization reforms. Our work provides further evidence to the debate on the effects of privatization in the water sector by estimating a translog stochastic frontier production function and a Parametric Generalized Malmquist productivity index. Overall, we find that the privatization reforms and the participation of multinational water firms contributed to the performance improvement of the Chinese water sector during 1999-2006. Additionally, the policy had positive effects on the performance achievement. We conclude that the Chinese water sector achieved productivity growth at the initial stage of the privatization reforms (1999-2006).

The productivity growth in the observation period was mainly achieved through technical change. This conclusion is consistent with the literature in the field (Bottasso and Conti, 2003; Saal et al., 2007). The massive investments in the water sector during 1999-2006 caused a negative value of the scale efficiency change due to the diseconomies-of-scale character of the water sector. This effect was also identified by other scholars (Saal and Parker, 2000; Saal et al., 2007; Filippini et al., 2008). In general, we find positive technical efficiency changes, though at a modest level. This suggests that there is no significant catching up with the sector frontier in the observation period.

We classify water firms based on their ownership, and furthermore, we examine the effects of ownership on productivity. The foreign-owned water firms formed the sector's frontier and had the highest technical efficiency scores and technical change rate. Interestingly, the domestic privately owned water firms also had very good performance in the sample period. We observe a high technical efficiency score of approximately 0.98 on average for domestic privately owned water firms. Although state-owned water firms had the lowest technical efficiency scores, their productivity improved over time in the observation period, but only to a small extent. In contrast to domestic privately owned water firms and foreign owned water firms, state-owned water firms were restricted by the substantial accumulation of obsolete equipment, excess employees and backward management practices, which hindered their performance during the privatization reforms. Without these heavy burdens, domestic privately owned firms could easily embrace the newest technology. The potential reason for the inferior performance of domestic privately owned water firms might be the managerial differences from their foreign competitors, which requires long time to learn.

From a policy perspective, our result affirmed the success of the relevant policies' design and implementation, which were meant to improve the water sector's technologies. In our model, we also test the policy's effects using the inefficiency term. However, we found a statistically insignificant correlation between the policy dummy variables and the inefficiency term. This insignificance might be caused by the short observation period. We would expect to find a statistically significant 
result when data with larger $\mathrm{T}$ are available. Therefore, long-term policy interventions and monitoring are important to the success of privatization and marketoriented reforms in the water sector.

Moreover, our result potentially explained the privatization failures of the water sector in some developing countries, such as Bolivia, Venezuela and Malaysia. In those countries, the governments left the water sector to the free markets completely without careful monitoring or proper intervention. Notably, the watersector-privatization reforms in those countries were dominated by multinational corporations. And domestic water firms did not obtain enough support and protection, they did not have the ability to compete directly with multinational corporations. As a result, the water services' quality significantly dropped and prices dramatically increased after the privatization of the water sector, which led to massive demonstrations against it. In contrast, the privatization of the water sector in China is accompanied by the participation of foreign private water sector, the reorganization of state-owned water firms, and the fast growth of domestic privately owned water firms. The Chinese government not only welcomed the foreign investors but also strongly supported the development of domestic water firms. As a result, we witness the prosperity of the water sector in China in which state-owned, foreign owned and domestic privately owned water firms were all actively involved.

Our work potentially contributes to the literature of neo-liberalism and the empirical literature of water sector productivity, as it shows that privatization could contribute to efficiency achievements in public water sectors in developing countries. However, this feat relies on proper government intervention and guidance. Our study provides useful information for the Chinese water authorities, as it carefully evaluated the effects of privatization on the water sector in China during 1999-2006. Generally, our methods could be used as valuable tools for the water authorities to evaluate the sector and design new policies. Moreover, our findings are valuable for water policy-makers in other developing countries, as they provide evidence of successful water privatization reforms in the developing world. Notably, the privatization reform of the Chinese water sector was accompanied with strong policy interventions, which positively affected the result of the privatization reforms. However, the degree to which the policy interventions can influence the privatization reforms largely depends on the central and local governments' ability to intervene. 


\section{CHAPTER 5}

\section{Environmental concern and water consumption behavior: \\ Multilevel analysis of China}




\section{$5.1 \quad$ Introduction}

The synthesis of individual behavior determines the outcome of an entire society. Therefore, the environmental concern and environmental behavior of citizens are crucial for solving environmental problems and for maintaining the sustainable development of the society. Researchers and policy makers have become increasingly aware that individual behavior can ameliorate or exacerbate environmental problems. Citizens have different roles and responsibilities and should be proactively involved in environmental protection activities. With the increasing deterioration of the environment in many urban areas in China, a better understanding of the public environmental concern and environmental behavior has become more important than ever.

Researchers and scholars in sociology and psychology have found that enhanced environmental concern stimulates environmentally friendly behavior at an individual level, such as water conservation behavior. Thus, it is important to understand the concern citizens have for the environment and its determining factors at different levels. Based on the results of such an analysis, corresponding policies could be designed and implemented to increase individual environmental concern and consequently stimulate citizens' environmentally friendly behavior, which would lead to an environmentally friendly society.

As an environmentally friendly behavior, water conservation behavior is closely linked to a general environmental concern. At the individual level, environmental concern has positive influences on water conservation behavior (Corral-Verdugo et al., 2003; Gilg and Barr, 2006; Clark and Finley, 2007; Willis et al., 2011; Jorgensen et al., 2013).

Based on four waves of World Value Survey (WVS) data (1990, 1995, 2001 and 2007), we first examined the determinants of general environmental concern at the individual level by controlling provincial/regional level factors in China. By bridging environmental concern and water conservation behavior, our research results also provide useful information of impact factors of water conservation behavior.

Although previous studies have only focused on the individual level, we have adopted multilevel regression models to investigate the environmental concern determinants both at the individual and regional/provincial level. We argue that citizens' environmental concern is not only strongly linked to individual economic status, such as education level, employment status, age and gender, but it is also affected by the developmental status of their local environment. Our study contributes to the literature evaluating environmental concern because it quantitatively examines the determinants of environmental concern both at the individual and group level in China. A clear advantage of national studies in this field is the possibility of designing country-level environmental initiatives and corresponding policies. Hence, our study has the potential to provide valuable information to 
environmental authorities, especially water authorities in China. With a deeper understanding of the environmental concern determinants that strongly affect individual water conservation behavior, the water authorities should be able to improve the associated policies, which should stimulate environmental concern and water conservation behavior and lead to a water-conserving society.

The structure of this chapter proceeds as follows: Section 2, we review the theoretical and empirical literature of environmental concern determinants, both at the individual and group levels; in Section 3, we present the methodology adopted in this study, which is a multilevel logit regression model; section 4 introduces the dataset used in this study; section 5 contains the definitions and information for all of the variables; in section 6, the results are discussed; and section 7 offers the conclusion of this chapter and additional policy discussions.

\subsection{Literature Review}

\subsubsection{Environmental Concern}

Environmental concern is defined in several ways in the environmental literature because of the different research focuses. Among all of the definitions, the definition of environmental concern given by Van Liere and Dunlap (1980) was the most comprehensive and included multi-level components in the definition. According to Van Liere and Dunlap, environmental concern is defined as "perceiving environmental problems as serious, supporting efforts by the government to protect environmental quality and engaging in behavior aimed at improving environmental quality". Environmental concern consists of four separate components in this definition (Schaffrin, 2011): 1) the cognitive component refers to personal knowledge and beliefs related to causes, responsibilities, and solutions for environmental problems; 2) the affective component adds an emotional or evaluative part in which the seriousness of an environmental problem is evaluated; 3) the conative component is the intention of personal action in the consideration of certain environmental problems and activated by the affective component; and 4) the behavior component, which transfers the intention to actions.

Environmental Value is the cognitive component of environmental concern. It is the stable, internalized cognitive concepts that guide individual behavior or evaluations (Rannikko, 1996; Wesley Schultz, 2001; Hirsh, 2010). "Values are distinct from attitude because they function as an organized system and are typically viewed as determinants of attitude and behavior" (Wesley Schultz and Zelezny, 1999). Environmental attitude corresponds to the affective and conative components in the environmental concern definition. Based on the theory of planned behavior, the strength of intention is a proximal cause of behavior (Fransson and Garling, 1999). Environmental action is the personal choice which can mitigate environmental pollution or to save natural resources, and it is also affected by the value and attitude components. 
In Homer and Kahle's work (1988), they assumed a value-attitude-behavior hierarchy of environmental concern. According to their model, value influences behavior both directly and indirectly through attitude. In this hierarchical system, individual environmental value is shaped by the social structures that guide the development of belief systems and worldviews. In turn, belief systems and worldviews lead to formation of new attitudes related to specific environmental issues. These attitudes and beliefs further influence behavioral commitments and intentions, which affect environmental actions. This hierarchy model has received empirical support (Dietz et al., 1998; Cameron, 2002).

Water conservation behavior is a proactive environmental action and closely related to the other two dimensions of environmental concern. According to Ajzen and Fishbein's (1980) Theory of Planned Behavior (TPB), a hierarchical relationship exists among environmental value, environmental attitude and environmental action. Ajzen and Fishbein's theory incorporates normative social influence on behavioral intention and builds on the expectancy value theory to conceptualize the linkages between value, attitude and behavior (Hassell and Cary, 2007). Based on Ajzen and Fishbein's planned behavior theory, environmental value and the attitude of consumers directly impact their water consumption behavior, which belongs to environmental action.

Empirically, the link between general environmental value, attitude and water conservation behaviors has been proven in numerous studies (Corral-Verdugo et al., 2003; Korfiatis et al., 2004; Gilg and Barr, 2006; Clark and Finley, 2007; etc.). Thøgersen and Ölander (2002) conducted the first systematic analysis of the direction of causality between value and environmental behavior using the Danish data. They found that value priorities are very consistent and the learning can influence behavior in the short or medium term and affect value in the long run. Gilg and Barr (2006) further examined the general link between environmental action and water conservation behavior. Their results indicated that there is a positive correlation between environmental actions and water conservation behavior. Takács-Sánta (2007) showed that environmental attitude is more closely linked to behavior than environmental value.

Different indicators were adopted in the empirical studies to represent environmental concern. Environmental value is normally measured by questions related to the relationship between human beings and nature, such as if humans should master nature or coexist with nature. Environmental attitudes are mainly measured by the intention to act or support environmentally friendly actions, such as by donating to environmental protection or supporting increases in taxes or expenditures for environmental protection. Environmental action is generally measured by the frequency or degree of certain activities related to environmental protection, such as water conservation behavior, the purchase of green products, etc. Such indicators reflect different levels and perspectives of environmental concern. 


\subsubsection{Determinants of Environmental Concern}

A large body of work over the last four decades has explored the determinants of environmental values, attitudes and actions. The level of environmental concern in a particular nation could stem from several potential sources: subsistence threats; need for biological and psychological processes to exist in harmony with nature; level of education; cultural/institutional differences; and economic affluence (Duroy, 2008). Two groups of determinants of environmental concern can be found in the literature. The first group of determinants contains the individual level of social-demographic and psychological factors, which includes age, education, gender, income, employment status, financial satisfaction, trust, geographic pride, etc. The second group of variables focuses on the socio-economic perspective of the entire society at a higher level, such as the GDP per capita, urbanization, population density, and income inequality (Diekmann and Franzen, 1999; Franzen, 2003; Duroy, 2005 and 2008; Franzen and Meyer, 2010; Kim and Kim, 2010; Givens and Jorgenson, 2011; Fairbrother, 2013).

\subsubsection{Individual-level Social-demographic and Psychological Determinants}

At the individual level, age, education, income, gender, employment status, financial satisfaction, trust and geographical pride were common social-demographic and psychological determinations of environmental concern that have been examined in the literature.

\subsubsection{Social-demographic Determinants}

Age: Age or birth-cohort effects are among the most commonly used variables in models of environmental concern. Van Liere and Dunlap (1980) reviewed 11 studies, and all of them reported predominantly negative correlation coefficients between age and environmental concern. Franzen and Meyer (2010) confirmed this effect, finding age to be a significantly negative driver of environmental concern in all four of their models. However, the results of the correlation between age and environmental concern are mixed or not statistically significant in other studies (Dietz et al., 1998; Steel, 1996), which might be a result of the cohort effects and life-cycle effects. The cohort effects imply that people of the same age may have different environmental concerns and behavioral patterns because they have been exposed to different social and environmental events. Life-cycle effects refer to changes in a person's environmental concern and behavior over time. As a result, the function of age, cohort effects and life-cycle effects may lead to complex results.

Education: Education is an important driver of environmental concern, and it is closely linked to environmental knowledge. Education is also of particular policy interest because policies that intervene in the provision of education are comparatively easier for governments than other factors, such as age, ethnicity or wealth distribution. Environmental processes, and the data used to describe them, are complex and difficult to understand. Intuitively, one might expect greater levels of education to increase a person's capacity to grasp complex environmental issues 
and the multifaceted processes surrounding environmental risks. Empirical studies support the theoretical argument that education has a positive effect on environmental concern (Steel, 1996; Hayes, 2001; Franzen and Meyer, 2010).

Income: Income is one of the key determinants of environmental concern considered in the literature (Torgler and Garcia-Valiñas, 2007). A possible theoretical justification is Maslow's hierarchy of needs (1970), which suggests that environmental concern and activism is perceived to be "something of a luxury which can be indulged only after more basic material needs are met" (Van Liere and Dunlap, 1980). Low income individuals are likely to see such risks as a low priority because of more pressing needs, such as paying rent, finding stable employment and raising children. However, rising income implies an increased cost of time, making wealthier individuals less likely to be involved in environmental actions. The combination of the two effects might lead to higher earners having a higher environmental concern but not necessarily a higher rate of environmental involvement. Moreover, individuals with higher incomes may be insulated from the effects of environmental risks because they can afford insurance premiums and the costs of moving to and living in low-risk areas.

Gender: Gender is a potentially important determinant of environmental concern. Van Liere and Dunlap (1980) argued that men are more concerned about environmental problems because they are more likely to be politically active and involved in community issues and have higher education levels than women. However, other scholars reached the opposite conclusion and believe that men are more likely to be concerned with other issues, such as their jobs, income and economic growth, and less concerned than women on environmental protections. Moreover, women may be more concerned with their children, which might increase their interest in the environment. Empirical studies have shown a mixed picture. Hayes (2001) used the environmental survey from a 1993 international social survey program to conduct a multinational study in which no differences between the genders were found in terms of environmental attitudes. Anderson et al. (2010) found similar results when they examined the Home Office Citizenship Survey data from the UK for 2003. In 2005, however, men were significantly less likely to care about the environment or be involved in environmental actions than women.

Employment status: The impacts of employment status on environmental concern were mixed and unclear in the literature. Anderson and his coauthors (2010) found that individuals with management and intermediate jobs were far more likely to have a positive environmental attitude than individuals without a job, whereas Witzke and Urfei (2001) discovered that individuals engaged in household work or on maternity leave had higher environmental preferences. Veisten et al. (2004) showed that unemployed people occasionally present lower preferences for environmental protection policies. However, the relationship between employment status and environmental concern is often unclear or insignificant (Engel and Pötchske 1998, Witzke and Urfei 2001). 


\subsubsection{Psychological Determinants}

Financial satisfaction: In addition to the objective fiscal condition, the subjective satisfaction of income also affects a citizen's environmental concern. This is due to the fact that the financial satisfaction of an individual may not only depend on his/her real income level, but also depend on the perception of his/her financial pressure (Torgler and Garcia-Valiñas, 2005). Financial satisfaction might positively influence the preference to donate more to environmental protection and the willingness to pay higher taxes to preserve the environment.

Trust: Trust is used to represent social capital. According to Paldam (2000), strong social capital leads people to build trust and cooperate with each other. Citizens with strong trust may have more concern related to common interests, such as the environment, which makes them more willing to contribute to environmental protection (Torgler and Garcia-Valiñas, 2007). Therefore, trust could be a crucial aspect in explaining and individual's attitudes and actions related to environmental protection.

Geographical pride: In general, pride influences an individual's behavior in groups, organizations and societies (Tyler, 2000) and produces a basis for encouraging cooperative behavior on environment protection. Individuals who see themselves as citizens of the world may have relatively high environmental values because many cases of environmental pollution produce high externalities at the global level. However, individuals strongly attached to local areas are less likely to act as 'free riders' of environmental policies and generally have a stronger willingness to reduce environmental damages at the local level and a greater willingness to accept higher taxes and act to protect the environment. Based on the WVS for the periods 1990, 1995 and 1999/2000, Torgler and Garia-Valinas (2005) showed that geographic pride has a positive correlation with environmental concern.

\subsubsection{Group-level Socio-economic Determinants}

At a higher level, such as at the regional or national levels, socio-economic determinants also affect the formation of environmental concern among citizens. Citizens in different regions or nations may express different environmental concerns because they are exposed to different cultures, developmental conditions and environments. In the literature, the GDP per capita, urbanization, population density and income inequality are the common determinants controlled and investigated at the regional or national level.

GDP per capita: The GDP per capita is used as a proxy of economic development in the environmental and developmental economic literature. According to Inglehart's "objective problem and subjective value" hypothesis $(1995,1997)$, increased environmental concern in a country or region is affected by two different factors depending on a country/region's affluence and pressure regarding environmental problems. The "subjective value" implies that rich countries have a larger proportion of post-materialists who give less priority to economic issues and greater 
attention to other values, such as the concern for protecting the natural environment. The "objective problem" refers to the fact that poor nations face urgent environmental problems that lead to the increased support of environmental protection. However, Franzen questioned the post-materialism argument in Inglehart's "subjective value" hypothesis and argued that citizens could remain materialists in all other issues but still favor additional environmental protection because when a country becomes wealthier, it has more resources to reallocate to environmental protection; therefore, the demand for a clean environment will be increased. Both effects working together may lead to a non-linear relationship between the GDP per capita and environmental concern. Inglehart (1995) tested his hypothesis based on data for 43 countries from the World Value Survey and showed that countries with high GNP per capita, such as the Netherlands, Sweden, Denmark, etc., show the greatest support for environmental protection. At the same time, support is also high in poorer countries that face significant environmental problems, such as Turkey, Russia and the Czech Republic. By analyzing the 1993 ISSP (International Social Survey Programme) survey data, Diekmann and Franzen (1999) found that the correlation between the GNP per capita and an index of priority of global environmental concern was 0.84 , which strongly supported the affluence hypothesis. Subsequently, Franzen (2003) conducted similar research based on 2000 ISSP data that showed that higher proportions of citizens in wealthier nations prefer general environmental protection to economic growth than citizens in poorer countries. However, this result does not mean that citizens in poorer nations are less concerned with the quality of their local environment. People in poorer countries facing urgent environmental problems have significant concern for their local environments. Empirically, Brechi and Kemption (1994), Dunlap and Mertig (1995) and Martinez-Alier (1995) showed that citizens in poorer nations have a higher concern for local environmental issues than residents in developed countries. Based on the data for 35 countries from the World Values Survey 1995-1997, Duroy (2008) suggested and proved the existence of a Ushaped relationship between the GDP per capita and measures of environmental action.

Urbanization: The percentage of the urban population is used as a proxy of urbanization. According to the biophilia hypothesis (Wilson, 1984; Kellert, 1993), there is an instinctive bond between human beings and other living systems. Hence, populations who are more likely to be removed from nature may have additional concern for nature. Thus, they may be more likely to express a desire to preserve the environment because they might feel the negative impact of its absence. However, this argument is based on a rather stabilized population formation, such as rich nations with a stabilized population division between urban and rural areas. In developing countries where urbanization is burgeoning, the urban population is formed by massive immigration from rural areas. Therefore, a positive correlation between urban populations and environmental protection in such conditions is questionable. The massive immigration of rural populations with comparatively low environmental concern may lead to a decrease of the average environmental concern in urban areas. 
Population density: Critics of conventional wisdom (Brechin and Kempton 1994, Martinez-Alier 1995, etc.) claimed that population pressure and industrial development are responsible for the emergence of environmental movements in thirdworld countries. Thus, it can be hypothesized that countries/regions with greater population density are more likely to create pressure on their environments and generate greater environmental concern.

Income Inequality: Magnani (2000) argued that societies characterized by a relatively equal distribution of income are more likely to express environmental concern and be committed to protecting the environment because the resources that would be spent on fighting inequality can be used to raise awareness and protect the environment. The Gini coefficient is the common measurement of economic inequality in the literature. A low Gini coefficient corresponds to a more equal distribution of income. Therefore, it is expected to be negatively correlated with environmental concern.

The existing empirical studies of environmental concern are mainly based on data collected from developed countries or mixed national level data both from developed and developing countries. The evidence base must be expanded for developing countries and other levels. Therefore, our study of Chinese environmental concern both at the individual and regional levels is meaningful. Moreover, by bridging environmental concern with water consumption behavior, our study also contributes to the water consumption behavior literature, which makes our work even more significant. In China, to our knowledge, no research has quantitatively examined the determinants of environmental concern both at the individual and regional levels. Almost all of the studies on Chinese environmental concern were based on single interview data. Our study with four waves of survey data provides inter-temporal comparisons that fill the gap in the literature. In addition, our investigation of three components in the hierarchy of environmental concern environmental value, environmental attitude and environmental action - provide deep insight into the environmental concern of individuals in China for the period 1990-2007.

\subsection{Methodology}

\subsubsection{Explanatory Factor Analysis}

Based on the literature examining environmental concern, we defined three components of environmental concern: environmental value, environmental attitude and environment action (Corraliza and Berenguer, 2000; Milfont et al., 2010; Schaffrin, 2011). However, we believe it is required and important to test the components of environmental concern through a factor analysis. In this study, we adopt an exploratory factor analysis rather than a confirmatory factor analysis because this is the first study to specifically examine determinants of environmental concern in China with WVS data at individual and regional levels. 
A factor analysis is a multivariate statistical approach commonly used in sociological and psychological studies and is considered the method of choice for interpreting self-reported questionnaires. Factor analysis is mainly used in three ways: 1) to reduce the number of variables into a smaller set of variables (also referred to as factors) to create indexes with variables that measure similar things; 2) establish the underlying dimensions between measured variables and latent constructs, therefore allowing the formation and refinement of theories; and 3) provide construct validity evidence of self-reporting scales. An exploratory factor analysis refers to a factor analysis without any pre-defined ideas of the structure and dimensions of a set of variables; by performing a factor analysis, the result will provide structure to and the number of dimensions of the data.

A factor analysis has common factors that linearly reconstruct the $p$ original variables:

$y_{i j}=z_{i 1} b_{1 j}+z_{i 2} b_{2 j}+\cdots+z_{i q} b_{q j}+e_{i j}$

where $y_{i j}$ is the value of the $i$ th observation of the $j$ th variable, $z_{i k}$ is the $i$ th observation of the $k$ th common factor, $b_{k j}$ is the set of linear coefficients called the factor loadings, and $e_{i j}$ is similar to a residual but is known as the $j$ th variable's unique factor. Everything except for the variables on the left is estimated, so the model has an infinite number of solutions. Various constraints are introduced to make the model determinate. With a principal components approach, reconstruction is defined in terms of the minimum residual variance summed across all of the equations (variables).

\subsubsection{Multilevel Regression Models}

In the literature, previous studies of environmental concern have often been used and usually comprise either the individual-level survey data or national-level aggregations of such data (Hox, 2010). When simultaneously considering the national and individual levels, multilevel models avoid conflicts related to which is the appropriate level and do not run the risks associated with ignoring either one.

A multilevel model is a regression model in which observations are made on units of analysis that are grouped, and the outcome of interest is in some way dependent on the groups to which the units belong. Multilevel models can provide accurate estimations of statistical uncertainty and significance and allow for a richer range of relationships to be explored; in our study, the relationship between regional level characteristics and outcomes in China is measured at the level of the individual respondent.

In this study, all of the environmental variables in the original survey data are ordinal categorical variables. Based on the factor analysis, we form three environmental concern indexes that are used as dependent variables in this study. Contrary to the inclusion of single environmental variables in the survey data, some of the 
newly established environmental concern indexes could be viewed as continuous variables, which depends on the formation of each index. When an index is formed with more than or equal to two variables and has more than three categorical levels, the categorical numbers become meaningful; thus, the index could be viewed as including continuous variables.

For those continuous environmental-concern dependent variables, we use a normal multilevel linear regression model. Regarding the categorical and dichotomous variables, the classical approach to the problem of non-normally distributed variables and heteroskedasticity errors is to apply a transformation to achieve normality and to reduce the heteroskedasticity. Logit transformation is one of the recommended transformations for such cases. In this study, we adopt a multilevel logistic regression model to consider ordinal categorical-dependent variables and dichotomous-dependent variables. In our multilevel regression models, provinciallevel differences were added to control the heterogeneity among regions because of the economic, cultural and geographic differences among provinces in China.

\subsubsection{Two-level Linear Regression Model for Continuous Dependent Variables}

The two-level linear regression model for continuous dependent variables could be expressed as a combination of a first-level and second-level model.

First-level model:

$Y_{i j}=\beta_{0 j}+\beta_{1 j} X_{1 i j}+\cdots+\beta_{k j} X_{k i j}+e_{i j}$

where $Y_{i j}$ is a dependent variable, $X_{k i j}$ is the $k$ th independent variable, $\beta_{k j}$ is the coefficient of the $k$ th independent variable, and $e_{i j}$ is the residual error term.

In the second-level model, the variation of the regression coefficients $\beta_{j}$ at provincial level is introduced to the multilevel model.

Second level model:

$$
\begin{gathered}
\beta_{0 j}=\gamma_{00}+\gamma_{01} z_{j}+u_{0 j} \\
\beta_{1 j}=\gamma_{10}+\gamma_{11} z_{j}+u_{1 j} \\
\vdots \\
\beta_{k j}=\gamma_{k 0}+\gamma_{k 1} z_{j}+u_{k j}
\end{gathered}
$$

where $\gamma_{k 0}$ is the intercept, $\gamma_{k 1}$ is the coefficient of provincial level variable $Z_{j}$, and $u_{k j}$ is the random residual error terms at second level. Combining the first level and second level model, we obtain the two-level linear regression model:

$$
\begin{aligned}
& Y_{i j}=\gamma_{00}+\left(\gamma_{10} X_{1 i j}+\cdots+\gamma_{k 0} X_{k i j}\right)+\left(\gamma_{11} Z_{j} X_{1 i j} \cdots+\gamma_{k 1} Z_{j} X_{k i j}\right)+\gamma_{01} Z_{j}+\left(u_{0 j}+\right. \\
& \left.u_{1 j} X_{1 i j}+\cdots+u_{k j} X_{k i j}\right)+e_{i j}
\end{aligned}
$$


In equation (4), there are two parts that form the two-level linear regression model, and the fixed part is expressed as follows:

$\gamma_{00}+\left(\gamma_{10} X_{1 i j}+\cdots+\gamma_{k 0} X_{k i j}\right)+\left(\gamma_{11} Z_{j} X_{1 i j} \cdots+\gamma_{k 1} Z_{j} X_{k i j}\right)+\gamma_{01} Z_{j}$

And the random part is expressed as follows:

$\left(u_{0 j}+u_{1 j} X_{1 i j}+\cdots+u_{k j} X_{k i j}\right)+e_{i j}$

Hence, our two-level linear regression model could be expressed as follows:

$$
\begin{aligned}
& \mathrm{EC}_{\mathrm{ij}}=\left(\gamma_{00}+\gamma_{10} \text { gender }_{\mathrm{ij}}+\gamma_{20} \text { age }_{\mathrm{ij}}+\gamma_{30} \text { edu }_{\mathrm{ij}}+\gamma_{40} \text { employ }_{\mathrm{ij}}+\gamma_{50} \text { income }_{\mathrm{ij}}+\right. \\
& \gamma_{60} \text { trust }_{\mathrm{ij}}+\gamma_{70} \mathrm{FS}_{\mathrm{ij}}+\gamma_{80} \mathrm{GP}_{\mathrm{ij}}+\gamma_{11} \mathrm{Z}_{\mathrm{j}} \text { gender }_{\mathrm{ij}}+\gamma_{21} \mathrm{Z}_{\mathrm{j}} \mathrm{age}_{\mathrm{ij}}+\gamma_{31} \mathrm{Z}_{\mathrm{j}} \text { edu }_{\mathrm{ij}}+ \\
& \left.\gamma_{41} \mathrm{Z}_{\mathrm{j}} \text { employ }_{\mathrm{ij}}++\gamma_{51} \mathrm{Z}_{\mathrm{j}} \text { income }_{\mathrm{ij}}+\gamma_{61} \mathrm{Z}_{\mathrm{j}} \text { trust }_{\mathrm{ij}}+\gamma_{71} \mathrm{Z}_{\mathrm{j}} \mathrm{FS}_{\mathrm{ij}}+\gamma_{81} \mathrm{Z}_{\mathrm{j}} \mathrm{GP}_{\mathrm{ij}}+\gamma_{01} \mathrm{Z}_{\mathrm{j}}\right)+ \\
& \left(\mathrm{u}_{0 \mathrm{j}}+\mathrm{u}_{1 \mathrm{j}} \text { gender }_{\mathrm{ij}}+\mathrm{u}_{2 \mathrm{j}} \text { age }_{\mathrm{ij}}+\mathrm{u}_{3 \mathrm{j}} \text { edu }_{\mathrm{ij}}+\mathrm{u}_{4 \mathrm{j}} \text { employ }_{\mathrm{ij}}+\mathrm{u}_{5 \mathrm{j}} \text { income }_{\mathrm{ij}}+\mathrm{u}_{6 \mathrm{j}} \text { trust }_{\mathrm{ij}}+\right. \\
& \left.\mathrm{u}_{7 \mathrm{j}} \mathrm{FS}_{\mathrm{ij}}+\mathrm{u}_{8 \mathrm{j}} \mathrm{GP}_{\mathrm{ij}}+\mathrm{e}_{\mathrm{ij}}\right)
\end{aligned}
$$

where EC refers to the environmental concern variable, FS represents financial satisfaction and GP refers to geographical pride. The first bracket includes the fixed-effects part of the model, and the second bracket contains the random effects part.

Five steps are conducted to gradually examine the relationship between independent variables and the environmental concern index variables at the individual level and provincial level.

\section{Step 1: Intercept-only Model}

We start with an intercept-only model. Intercept-only models are used as a null model (baseline model) that serves as a benchmark to which other models are compared.

For our study, the intercept-only model is written as follows:

$\mathrm{EC}_{\mathrm{ij}}=\gamma_{00}+\mathrm{u}_{0 \mathrm{j}}+\mathrm{e}_{\mathrm{ij}}$

\section{Step 2: Fixed-effect Model}

In the second step, we extend the null model with fixed effects for the individual level explanatory variables in which the slopes are assumed not to vary across groups. Therefore, we obtain:

$$
\begin{gathered}
\mathrm{EC}_{\mathrm{ij}}=\beta_{0 \mathrm{j}}+\beta_{1 \mathrm{j}} \text { gender }_{\mathrm{ij}}+\beta_{2 \mathrm{j}} \text { age }_{\mathrm{ij}}+\beta_{3 \mathrm{j}} \mathrm{edu}_{\mathrm{ij}}+\beta_{4 \mathrm{j}} \text { employ }_{\mathrm{ij}}+\beta_{5 \mathrm{j}} \text { income }_{\mathrm{ij}} \\
+\beta_{6 \mathrm{j}} \text { trust }_{\mathrm{ij}}+\beta_{7 \mathrm{j}} \mathrm{FS}_{\mathrm{ij}}+\beta_{8 \mathrm{j}} \mathrm{GP}_{\mathrm{ij}}+\mathrm{e}_{\mathrm{ij}}
\end{gathered}
$$




$$
\begin{aligned}
& \beta_{0 \mathrm{j}}=\gamma_{00}+\mathrm{u}_{0 \mathrm{j}} \\
& \beta_{1 \mathrm{j}}=\gamma_{10} \\
& \text { ! } \\
& \beta_{8 \mathrm{j}}=\gamma_{80} \\
& \mathrm{EC}_{\mathrm{ij}}=\gamma_{00}+\gamma_{10} \text { gender }_{\mathrm{ij}}+\gamma_{20} \text { age }_{\mathrm{ij}}+\gamma_{30} \mathrm{edu}_{\mathrm{ij}}+\gamma_{40} \text { employ }_{\mathrm{ij}}+\gamma_{50} \text { income }_{\mathrm{ij}} \\
& ++\beta_{60} \text { trust }_{i j}+\gamma_{70} \mathrm{FS}_{\mathrm{ij}}+\gamma_{80} \mathrm{GP}_{\mathrm{ij}}+\mathrm{u}_{0 \mathrm{j}}+\mathrm{e}_{\mathrm{ij}}
\end{aligned}
$$

\section{Step 3: Fixed-effect Model with group-level variable}

In the third step, we add high-level explanatory variables. This model allows us to examine whether the group-level explanatory variables explain the between-group variation in the dependent variable.

Therefore, we obtain:

$$
\begin{aligned}
& \quad \mathrm{EC}_{\mathrm{ij}}=\beta_{0 \mathrm{j}}+\beta_{1 \mathrm{j}} \text { gender }_{\mathrm{ij}}+\beta_{2 \mathrm{j}} \mathrm{age}_{\mathrm{ij}}+\beta_{3 \mathrm{j}} \mathrm{edu}_{\mathrm{ij}}+\beta_{4 \mathrm{j}} \mathrm{employ}_{\mathrm{ij}}+\beta_{5 \mathrm{j}} \text { income }_{\mathrm{ij}} \\
& \quad+\beta_{6 \mathrm{j}} \mathrm{trust}_{\mathrm{ij}}+\beta_{7 \mathrm{j}} \mathrm{FS}_{\mathrm{ij}}+\beta_{8 \mathrm{j}} \mathrm{GP}_{\mathrm{ij}}+\mathrm{e}_{\mathrm{ij}} \\
& \\
& \beta_{0 \mathrm{j}}=\gamma_{00}+\gamma_{01} \mathrm{Z}_{1 \mathrm{j}}+\mathrm{u}_{0 \mathrm{j}} \\
& \beta_{1 \mathrm{j}}=\gamma_{10} \\
& \vdots \\
& \beta_{8 \mathrm{j}}=\gamma_{80}
\end{aligned}
$$

$$
\begin{gathered}
\mathrm{EC}_{\mathrm{ij}}=\gamma_{00}+\gamma_{10} \text { gender }_{\mathrm{ij}}+\gamma_{20} \text { age }_{\mathrm{ij}}+\gamma_{30} \mathrm{edu}_{\mathrm{ij}}+\gamma_{40} \text { employ }_{\mathrm{ij}}+\gamma_{50} \text { income }_{\mathrm{ij}} \\
++\beta_{60} \text { trust }_{\mathrm{ij}}+\gamma_{70} \mathrm{FS}_{\mathrm{ij}}+\gamma_{80} \mathrm{GP}_{\mathrm{ij}}+\gamma_{01} \mathrm{Z}_{1 \mathrm{j}}+\mathrm{u}_{0 \mathrm{j}}+\mathrm{e}_{\mathrm{ij}}
\end{gathered}
$$

The models in step 2 and step 3 are often denoted as variance component models because they decompose the intercept variance into different variance components for each hierarchical level. In a variance component model, the regression intercept is assumed to vary across the groups, whereas the regression slopes are assumed to be fixed. If there is no higher-level explanatory variable, this model is equivalent to a random effect analysis of covariance. This model, which only includes fixed regression coefficients, is used initially because there is generally more information available on the fixed regression coefficients; therefore, they can be estimated with more precision than the variance components. After a well-fitting model for the fixed part has been obtained, the random part is modeled. 


\section{Step 4: Random Coefficient Model}

In the fourth step, we further extend our models with varying slopes- the random effects. This model assesses whether any of the slopes of any of the explanatory variables have a significant variance component between the groups. We assume that both the intercept and slopes vary across groups. At this stage, the provinciallevel control variable is not included in the model.

Therefore, we obtain:

$$
\begin{aligned}
& \mathrm{EC}_{\mathrm{ij}}=\beta_{0 \mathrm{j}}+\beta_{1 \mathrm{j}} \text { gender }_{\mathrm{ij}}+\beta_{2 \mathrm{j}} \text { age }_{\mathrm{ij}}+\beta_{3 \mathrm{j}} \text { edu }_{\mathrm{ij}}+\beta_{4 \mathrm{j}} \text { employ }_{\mathrm{ij}}+\beta_{5 \mathrm{j}} \text { income }_{\mathrm{ij}} \\
& +\beta_{6 j} \text { trust }_{i j}+\beta_{7 j} F_{i j}+\beta_{8 j} G_{i j}+e_{i j} \\
& \beta_{0 \mathrm{j}}=\gamma_{00}+\gamma_{01} \mathrm{z}_{1 \mathrm{j}}+\mathrm{u}_{0 \mathrm{j}} \\
& \beta_{1 \mathrm{j}}=\gamma_{10}+\mathrm{u}_{1 \mathrm{j}} \\
& \beta_{8 \mathrm{j}}=\gamma_{80}+\mathrm{u}_{8 \mathrm{j}} \\
& \mathrm{EC}_{\mathrm{ij}}=\gamma_{00}+\gamma_{10} \text { gender }_{\mathrm{ij}}+\gamma_{20} \text { age }_{\mathrm{ij}}+\gamma_{30} \mathrm{edu}_{\mathrm{ij}}+\gamma_{40} \text { employ }_{\mathrm{ij}}+\gamma_{50} \text { income }_{\mathrm{ij}} \\
& ++\beta_{60} \text { trust }_{\mathrm{ij}}+\gamma_{70} \mathrm{FS}_{\mathrm{ij}}+\gamma_{80} \mathrm{GP}_{\mathrm{ij}}+\gamma_{01} \mathrm{Z}_{1 \mathrm{j}}+\mathrm{u}_{0 \mathrm{j}}+\mathrm{u}_{1 \mathrm{j}} \text { gender }_{\mathrm{ij}} \\
& +\mathrm{u}_{2 \mathrm{j}} \text { age }_{\mathrm{ij}}+\mathrm{u}_{3 \mathrm{j}} \text { edu }_{\mathrm{ij}}+\mathrm{u}_{4 \mathrm{j}} \text { employ }_{\mathrm{ij}}+\mathrm{u}_{5 \mathrm{j}} \text { income }_{\mathrm{ij}}+\mathrm{u}_{6 \mathrm{j}} \text { trust }_{\mathrm{ij}} \\
& +u_{7 j} F_{i j}+u_{8 j} G_{i j}+e_{i j}
\end{aligned}
$$

where $u_{q j}$ are the group-level residuals of the slopes.

Testing for random slope variation is best performed based on individual variables. Including all of the possible variance terms in a model can result in an overly parameterized model with serious estimation problems, such as convergence problems or extremely slow computations. Variables that were omitted in step 2 may be analyzed again in this step, and it is possible for an explanatory variable to have an insignificant average regression slope and a significant variance component for the slope.

\section{Step 5: Full Multilevel Regression Model}

In the last step, we run the full multilevel linear regression model by adding crosslevel interactions between explanatory group-level variables and the individuallevel explanatory variables that had significant slope variations in step 4 , which leads to the full model:

$$
\begin{gathered}
\mathrm{EC}_{\mathrm{ij}}=\beta_{0 \mathrm{j}}+\beta_{1 \mathrm{j}} \text { gender }_{\mathrm{ij}}+\beta_{2 \mathrm{j}} \text { age }_{\mathrm{ij}}+\beta_{3 \mathrm{j}} \mathrm{edu}_{\mathrm{ij}}+\beta_{4 \mathrm{j}} \text { employ }_{\mathrm{ij}}+\beta_{5 \mathrm{j}} \text { income }_{\mathrm{ij}} \\
+\beta_{6 \mathrm{j}} \text { trust }_{\mathrm{ij}}+\beta_{7 \mathrm{j}} \mathrm{FS}_{\mathrm{ij}}+\beta_{8 \mathrm{j}} \mathrm{GP}_{\mathrm{ij}}+\mathrm{e}_{\mathrm{ij}}
\end{gathered}
$$




$$
\begin{gathered}
\beta_{0 j}=\gamma_{00}+\gamma_{01} z_{1 j}+u_{0 j} \\
\beta_{1 j}=\gamma_{10}+\gamma_{11} z_{1 j}+u_{1 j} \\
\vdots \\
\beta_{8 j}=\gamma_{80}+\gamma_{81} z_{1 j}+u_{8 j}
\end{gathered}
$$

where $i$ represents the $i$ th individual and the subscript $j$ represents the provinces.

$$
\begin{aligned}
& \mathrm{EC}_{\mathrm{ij}}=\left(\gamma_{00}+\gamma_{10} \text { gender }_{\mathrm{ij}}+\gamma_{20} \text { age }_{\mathrm{ij}}+\gamma_{30} \text { edu }_{\mathrm{ij}}+\gamma_{40} \text { employ }_{\mathrm{ij}}+\gamma_{50} \text { income }_{\mathrm{ij}}\right. \\
&+\gamma_{60} \text { trust }_{\mathrm{ij}}+\gamma_{70} \mathrm{FS}_{\mathrm{ij}}+\gamma_{80} \mathrm{GP}_{\mathrm{ij}}+\gamma_{11} \mathrm{Z}_{\mathrm{j}} \text { gender }_{\mathrm{ij}}+\gamma_{21} \mathrm{Z}_{\mathrm{j}} \text { age }_{\mathrm{ij}} \\
&+\gamma_{31} \mathrm{Z}_{\mathrm{j}} \text { edu }_{\mathrm{ij}}+\gamma_{41} \mathrm{Z}_{\mathrm{j}} \text { employ }_{\mathrm{ij}}++\gamma_{51} \mathrm{Z}_{\mathrm{j}} \text { income }_{\mathrm{ij}}+\gamma_{61} \mathrm{Z}_{\mathrm{j}} \text { trust }_{\mathrm{ij}} \\
&\left.+\gamma_{71} \mathrm{Z}_{\mathrm{j}} \mathrm{FS}_{\mathrm{ij}}+\gamma_{81} \mathrm{Z}_{\mathrm{j}} \mathrm{GP}_{\mathrm{ij}}+\gamma_{01} \mathrm{Z}_{\mathrm{j}}\right)+\left(\mathrm{u}_{0 \mathrm{j}}+\mathrm{u}_{1 \mathrm{j}} \text { gender }_{\mathrm{ij}}+\mathrm{u}_{2 \mathrm{j}} \text { age }_{\mathrm{ij}}\right. \\
&+\mathrm{u}_{3 \mathrm{j}} \mathrm{edu}_{\mathrm{ij}}+\mathrm{u}_{4 \mathrm{j}} \text { employ }_{\mathrm{ij}}+\mathrm{u}_{5 \mathrm{j}} \text { income }_{\mathrm{ij}}+\mathrm{u}_{6 \mathrm{j}} \text { trust }_{\mathrm{ij}}+\mathrm{u}_{7 \mathrm{j}} \mathrm{FS}_{\mathrm{ij}} \\
&\left.+\mathrm{u}_{8 \mathrm{j}} \mathrm{GP}_{\mathrm{ij}}+\mathrm{e}_{\mathrm{ij}}\right)
\end{aligned}
$$

\subsubsection{Two-level Ordered Logistic Regression Model for Ordinal Responses}

For the ordinal categorical variables, we adopt a two-level ordered logistic regression model. We assume that there is an unobservable latent variable $\eta_{i}$ that is related to the actual ordinal response $y_{i}$ through the "threshold concept," which is defined as a series of threshold values, $\theta_{1}, \theta_{2}, \cdots \theta_{c-1}$, where $C$ is equal to the number of ordered categories, $\theta_{0}=-\infty$ and $\theta_{c}=\infty$. Here, a response occurs in category $C, y_{i}=C$ if the latent response process $\eta_{i}$ exceeds the threshold value $\theta_{c-1}$ but does not exceed the threshold value $\theta_{c}$, namely $\theta_{c-1}<\eta_{i} \leq \theta_{c}$.

$y_{i}=\left\{\begin{array}{c}1, \text { and if } \eta_{i} \leq \theta_{1} \\ 2, \text { and if } \theta_{1}<\eta_{i} \leq \theta_{2} \\ \vdots \\ C, \text { and if } \theta_{c-1} \leq \eta_{i}\end{array}\right.$

$\operatorname{Pr}\left(\mathrm{y}_{\mathrm{i}}=\mathrm{c} \mid \mathrm{x}_{\mathrm{i}}\right)=\mathrm{p}_{\mathrm{c}}$

The cumulative probabilities are given by:

$\mathrm{p}_{\mathrm{c}}^{*}=\sum_{1}^{\mathrm{c}} \mathrm{p}_{\mathrm{c}}$

A generalized linear model is usually defined by three components: 
1 An outcome variable y with a specific error distribution that has a mean $\mu$ and a variance $\sigma^{2}$;

2 A linear additive regression equation that produces a predictor $\eta$ of the outcome variable y; and

3 A link function that links the expected values of the outcome variable $y$ to the predicted values for $\eta: \eta=f(\mu)$.

For a logistic regression, we include the logit link function:

$\eta_{\mathrm{c}}=\operatorname{logit}\left(\mathrm{p}_{\mathrm{c}}^{*}\right)=\ln \left(\frac{\mathrm{p}_{\mathrm{c}}^{*}}{1-\mathrm{p}_{\mathrm{c}}^{*}}\right)$

Assume that there are $i=1,2, \cdots, N$ individuals nested in groups $j=1,2, \cdots, M$. The linear regression model is constructed on the underlying logit scale, which has a mean of zero and variance of $\pi^{2} / 3$. As a consequence, there is no lowest-level error term $e_{i j}$ because it is part of the specification of the error distribution. In our model, the error distribution is a logistic distribution.

Therefore, the lowest level equations are:

$$
\begin{gathered}
\eta_{1 \mathrm{ij}}=\theta_{1 \mathrm{j}}+\beta_{1 \mathrm{j}} X_{\mathrm{ij}} \\
\eta_{2 \mathrm{ij}}=\theta_{2 \mathrm{j}}+\beta_{1 \mathrm{j}} X_{\mathrm{ij}} \\
\vdots \\
\eta_{\mathrm{cij}}=\theta_{\mathrm{cj}}+\beta_{1 \mathrm{j}} X_{\mathrm{ij}}
\end{gathered}
$$

where $\theta_{1} \cdots \theta_{c}$ are the intercepts for the response outcomes. Under this condition, however, there is no measurement equivalence between the different groups, and it is impossible to make meaningful comparisons. Therefore, the model is rewritten by subtracting the value of the first threshold from all of the thresholds; the first threshold then becomes zero and is effectively removed from the model. The first threshold is replaced by an overall intercept that is allowed to vary across the groups.

Thus, we obtain the revised lowest-level model:

$$
\begin{gathered}
\eta_{1 \mathrm{ij}}=\beta_{0 \mathrm{j}}+\beta_{1 \mathrm{j}} X_{\mathrm{ij}} \\
\eta_{2 \mathrm{ij}}=\theta_{2}+\beta_{0 \mathrm{j}}+\beta_{1 \mathrm{j}} X_{\mathrm{ij}} \\
\vdots \\
\eta_{\mathrm{cij}}=\theta_{\mathrm{c}}+\beta_{0 \mathrm{j}}+\beta_{1 \mathrm{j}} \mathrm{X}_{\mathrm{ij}}
\end{gathered}
$$

where $\theta_{c}$ is equal $\theta_{c}-\theta_{1}$; here, $\theta_{c}$ does not have a subscript for the groups because they are assumed to be fixed to maintain the measurement invariance across the groups. Notably, the value for $\beta_{0}$ is now equal to $-\theta_{1}$ in the original equation.

In this study, we could express our model as: 


$$
\begin{aligned}
\eta_{\mathrm{cij}}=\theta_{\mathrm{c}}+\beta_{0 \mathrm{j}}+ & \beta_{1 \mathrm{j}} \text { gender }_{\mathrm{ij}}+\beta_{2 \mathrm{j}} \mathrm{age}_{\mathrm{ij}}+\beta_{3 \mathrm{j}} \mathrm{edu}_{\mathrm{ij}}+\beta_{4 \mathrm{j}} \text { employ }_{\mathrm{ij}}+\beta_{5 \mathrm{j}} \text { income }_{\mathrm{ij}} \\
& +\beta_{6 \mathrm{j}} \text { trust }_{\mathrm{ij}}+\beta_{7 \mathrm{j}} \mathrm{FS}_{\mathrm{ij}}+\beta_{8 \mathrm{j}} \mathrm{GP}_{\mathrm{ij}}
\end{aligned}
$$

$$
\begin{gathered}
\beta_{0 j}=\gamma_{00}+\gamma_{01} z_{0 j}+u_{0 j} \\
\beta_{1 j}=\gamma_{10}+\gamma_{11} z_{1 j}+u_{1 j} \\
\vdots \\
\beta_{8 j}=\gamma_{80}+\gamma_{81} z_{8 j}+u_{8 j}
\end{gathered}
$$

where $i$ represents the $i$ th individual, the subscript $j$ represents the provinces, and $Z_{q j}$ are the $q$ explanatory variables at the group level.

$$
\begin{aligned}
\eta_{\text {cij }}=\left(\theta_{c}+\gamma_{00}\right. & +\gamma_{10} \text { gender }_{i j}+\gamma_{20} \text { age }_{i j}+\gamma_{30} \text { edu }_{\mathrm{ij}}+\gamma_{40} \text { employ }_{\mathrm{ij}}+\gamma_{50} \text { income }_{\mathrm{ij}} \\
& +\gamma_{60} \text { trust }_{\mathrm{ij}}+\gamma_{70} \mathrm{FS}_{\mathrm{ij}}+\gamma_{80} \mathrm{GP}_{\mathrm{ij}}+\gamma_{11} \mathrm{Z}_{\mathrm{j}} \text { gender }_{\mathrm{ij}}+\gamma_{21} \mathrm{Z}_{\mathrm{j}} \text { age }_{\mathrm{ij}} \\
& +\gamma_{31} \mathrm{Z}_{\mathrm{j}} \mathrm{edu}_{\mathrm{ij}}+\gamma_{41} \mathrm{Z}_{\mathrm{j}} \text { employ }_{\mathrm{ij}}++\gamma_{51} \mathrm{Z}_{\mathrm{j}} \text { income }_{\mathrm{ij}}+\gamma_{61} \mathrm{Z}_{\mathrm{j}} \text { trust }_{\mathrm{ij}} \\
& \left.+\gamma_{71} \mathrm{Z}_{\mathrm{j}} \mathrm{FS}_{\mathrm{ij}}+\gamma_{81} \mathrm{Z}_{\mathrm{j}} \mathrm{GP}_{\mathrm{ij}}+\gamma_{01} \mathrm{Z}_{\mathrm{j}}\right)+\left(\mathrm{u}_{0 \mathrm{j}}+\mathrm{u}_{1 \mathrm{j}} \text { gender }_{\mathrm{ij}}+\mathrm{u}_{2 \mathrm{j}} \text { age }_{\mathrm{ij}}\right. \\
& +\mathrm{u}_{3 \mathrm{j}} \mathrm{edu}_{\mathrm{ij}}+\mathrm{u}_{4 \mathrm{j}} \text { employ }_{\mathrm{ij}}+\mathrm{u}_{5 \mathrm{j}} \text { income }_{\mathrm{ij}}+\mathrm{u}_{6 \mathrm{j}} \text { trust }_{\mathrm{ij}}+\mathrm{u}_{7 \mathrm{j}} \mathrm{FS}_{\mathrm{ij}} \\
& \left.+\mathrm{u}_{8 \mathrm{j}} \mathrm{GP}_{\mathrm{ij}}\right)
\end{aligned}
$$

In equation (23), the fixed effect part is clearly identifiable from the random effect part. Similar to the previous model, we also take five steps to gradually examine the relationship between the independent variables and the environmental concern index variables. Additional details can be found in Appendix D-1.

\subsubsection{Two-level Logistic Regression Model for Dichotomous Responses}

In the case of dichotomous variables as dependent variables, the two-level logistic regression model will be different from the ordinal response model. We assume that there is an unobservable latent continuous variable $\eta$ that is related to the actual dichotomous response $y_{i}$. If this latent response is greater than 0 , the observed response is 1 :

$y_{i j}=\left\{\begin{array}{cc}1 & \text { if } \eta>0 \\ 0 & \text { otherwise }\end{array}\right.$ 
The generalized linear model for a dichotomous variable is defined by three components:

1 An outcome variable $y$ with a specific error distribution that is binomial with a mean $\mu$;

2 A linear additive regression equation that produces a predictor $\eta$ of the outcome variable $y$, and

3 A link function that links the expected values of the outcome variable $y$ to the predicted values for $\eta: \eta=\operatorname{logit}(\mu)$

Therefore, the lowest level equation is:

$\eta_{\mathrm{ij}}=\beta_{0 \mathrm{j}}+\beta_{1 \mathrm{j}} \mathrm{X}_{1 \mathrm{ij}}+\cdots+\beta_{\mathrm{kj}} \mathrm{X}_{\mathrm{kij}}$

Note that the usual lowest-level residual variance $e_{i j}$ is not in the equation because it is part of the specification of the error distribution. If the error distribution is binomial, the variance is a function of the population proportion $y_{i j}: \sigma^{2}=\left(\frac{y_{i j}}{1-y_{i j}}\right)$ and does not have to be estimated separately.

The higher level equation is:

$\beta_{0 j}=\gamma_{00}+\gamma_{01} z_{0 j}+u_{0 j}$
$\beta_{1 j}=\gamma_{10}+\gamma_{11} z_{1 j}+u_{1 j}$
$\vdots$
$\beta_{8 j}=\gamma_{80}+\gamma_{81} z_{8 j}+u_{8 j}$

Therefore, in this study, we could express our model as:

$$
\begin{gathered}
\eta_{i j}=\beta_{0 j}+\beta_{1 j} \text { gender }_{i j}+\beta_{2 j} \text { age }_{i j}+\beta_{3 j} \text { edu }_{i j}+\beta_{4 j} \text { employ }_{i j}+\beta_{5 j} \text { income }_{i j}+\beta_{6 j} \text { trust }_{i j} \\
+\beta_{7 j} \mathrm{FS}_{\mathrm{ij}}+\beta_{8 \mathrm{j}} \mathrm{GP}_{\mathrm{ij}}
\end{gathered}
$$

$\beta_{0 \mathrm{j}}=\gamma_{00}+\gamma_{01} \mathrm{z}_{0 \mathrm{j}}+\mathrm{u}_{0 \mathrm{j}}$

$\beta_{1 \mathrm{j}}=\gamma_{10}+\gamma_{11} \mathrm{z}_{1 \mathrm{j}}+\mathrm{u}_{1 \mathrm{j}}$

$\beta_{8 j}=\gamma_{80}+\gamma_{81} z_{8 j}+u_{8 j}$

where $i$ represents the $i$ th individual, the subscript $j$ represents the provinces, and $Z_{q j}$ are the $q$ explanatory variables at the group level. 


$$
\begin{aligned}
& \eta_{\mathrm{ij}}=\left(\gamma_{00}+\gamma_{10} \text { gender }_{\mathrm{ij}}+\gamma_{20} \text { age }_{\mathrm{ij}}+\gamma_{30} \text { edu }_{\mathrm{ij}}+\gamma_{40} \text { employ }_{\mathrm{ij}}+\gamma_{50} \text { income }_{\mathrm{ij}}\right. \\
&+\gamma_{60} \text { trust }_{\mathrm{ij}}+\gamma_{70} \mathrm{FS}_{\mathrm{ij}}+\gamma_{80} \mathrm{GP}_{\mathrm{ij}}+\gamma_{11} \mathrm{Z}_{\mathrm{j}} \text { gender }_{\mathrm{ij}}+\gamma_{21} \mathrm{Z}_{\mathrm{j}} \text { age }_{\mathrm{ij}} \\
&+\gamma_{31} \mathrm{Z}_{\mathrm{j}} \mathrm{edu}_{\mathrm{ij}}+\gamma_{41} \mathrm{Z}_{\mathrm{j}} \text { employ }_{\mathrm{ij}}++\gamma_{51} \mathrm{Z}_{\mathrm{j}} \text { income }_{\mathrm{ij}}+\gamma_{61} \mathrm{Z}_{\mathrm{j}} \text { trust }_{\mathrm{ij}} \\
&\left.+\gamma_{71} \mathrm{Z}_{\mathrm{j}} \mathrm{FS}_{\mathrm{ij}}+\gamma_{81} \mathrm{Z}_{\mathrm{j}} \mathrm{GP}_{\mathrm{ij}}+\gamma_{01} \mathrm{Z}_{\mathrm{j}}\right)+\left(\mathrm{u}_{0 \mathrm{j}}+\mathrm{u}_{1 \mathrm{j}} \text { gender }_{\mathrm{ij}}+\mathrm{u}_{2 \mathrm{j}} \mathrm{age}_{\mathrm{ij}}\right. \\
&+\mathrm{u}_{3 \mathrm{j}} \text { edu }_{\mathrm{ij}}+\mathrm{u}_{4 \mathrm{j}} \text { employ }_{\mathrm{ij}}+\mathrm{u}_{5 \mathrm{j}} \text { income }_{\mathrm{ij}}+\mathrm{u}_{6 \mathrm{j}} \text { trust }_{\mathrm{ij}}+\mathrm{u}_{7 \mathrm{j}} \mathrm{FS}_{\mathrm{ij}} \\
&\left.+\mathrm{u}_{8 \mathrm{j}} \mathrm{GP}_{\mathrm{ij}}\right)
\end{aligned}
$$

Similar to the previous models, we also examine the relationship between independent variables and environmental concern index variables through five steps. Additional details can be found in Appendix D-2.

\subsection{Data Description}

\subsubsection{World Value Survey Data (World Value Survey Association)}

World Value Survey Data is a worldwide survey series that investigates social, cultural and political changes. It is conducted by the World Value Survey Association, which is a network of social scientists at leading universities around the world. Since 1981, the association has conducted 5 world value surveys. Environmental issues are one of the main topics in world value surveys, although the questions have been adjusted over time. Therefore, such questions have not appeared in every wave. In this study, we used the Chinese data from four waves of the World Value Survey conducted in 1990, 1995, 2001 and 2007. Based on a factor analysis and literature review, we selected eight questions (variables) for our study, which are also slightly different from year to year.

The 1990 survey contained 9 questions related to environmental issues. Based on the factor analysis, eight of them form three environmental concern indicators. In Table 5.1, we list the eight questions with detailed information. The 1995 survey contained 12 environmentally related questions, and 10 were identified by the factor analysis as forming the three environmental concern indicators in our study. Table 5.2 lists the 10 questions. 
Table 5.1: Environmental concern indexes of the 1990 WVS

\begin{tabular}{lcl}
\hline $\begin{array}{l}\text { Variable } \\
\text { code }\end{array}$ & $\begin{array}{c}\text { Corresponding } \\
\text { question number }\end{array}$ & Label \\
\hline v12 & 124 & Would give part of my income for the environment \\
v13 & 125 & Increase in taxes if used to prevent environmental pollution \\
v14 & 126 & Government should reduce environmental pollution \\
v15 & 127 & All talk of the environment makes people anxious \\
v16 & 128 & To combat unemployment, we have to accept environmental problems \\
v17 & 129 & Protecting environment and fighting pollution is less urgent than \\
v26 & 138 & suggested \\
v44 & 156 & Member: belong to conservation, environment, ecological organization \\
\end{tabular}

Similarly, the three environmental concern indicators in the 2001 WVS study were formed by 7 out of 9 environmental-related questions. Detailed information on the seven questions can be found in Table 5.3. In the 2007 WVS survey, 19 questions were related to environmental issues. Based on the factor analysis result and the consistency of the survey data, six questions formed the three environmental concern indicators. Table 5.4 provides detailed information on the six questions.

Table 5.2: Environmental concern indexes for the 1995 WVS

\begin{tabular}{lcl}
\hline $\begin{array}{l}\text { Variable } \\
\text { code }\end{array}$ & $\begin{array}{c}\text { Corresponding } \\
\text { question number }\end{array}$ & Label \\
\hline v41 & Q12 & Environment vs. economic growth \\
v49 & Q14-c & Master nature vs. coexist with nature \\
v38 & Q11-1 & Environment: tax increase \\
v39 & Q11-2 & Environment: higher prices \\
v42 & Q13-1 & Environmental action: select products that are better for environment \\
v43 & Q13-2 & Environmental action: recycle \\
v44 & Q13-3 & Environmental action: reduce water consumption \\
v45 & Q13-4 & Environmental action: attend meeting, sign petition \\
v46 & Q13-5 & Environmental action: contribute to environmental organization \\
v33 & Q9-5 & Membership of voluntary organizations: environmental organization \\
\hline
\end{tabular}

Table 5.3: Environmental concern indexes for the 2001 WVS

\begin{tabular}{lcl}
\hline $\begin{array}{l}\text { Variable } \\
\text { code }\end{array}$ & $\begin{array}{c}\text { Corresponding } \\
\text { question number }\end{array}$ & Label \\
\hline v36 & 15 & Environment and economic growth \\
v37 & 16 & Master nature vs. coexist with nature \\
v33 & $14-\mathrm{a}$ & would give part of my income for the environment \\
v34 & $14-\mathrm{b}$ & $\begin{array}{l}\text { increase in taxes if extra money was used to prevent environmental } \\
\text { pollution }\end{array}$ \\
& $14-\mathrm{c}$ & government should reduce environmental pollution \\
v35 & $19-8$ & voluntary org: conservation, environmental, animal rights \\
v61 & $18-8$ & belong: conservation, environmental, animal rights protection \\
v46 & & organizations \\
\hline
\end{tabular}


Table 5.4: Environmental concern indexes for 2007 WVS

\begin{tabular}{lcl}
$\begin{array}{l}\text { Variable } \\
\text { code }\end{array}$ & $\begin{array}{c}\text { Corresponding } \\
\text { question number }\end{array}$ & Label \\
\hline v88 & v88 & Important that this person looks after the environment \\
v104 & v104 & environment and economic growth \\
v105 & v105 & would give part of my income for the environment \\
v106 & v106 & $\begin{array}{l}\text { increase in taxes if extra money was used to prevent environmental } \\
\text { pollution }\end{array}$ \\
v107 & v107 & government should reduce environmental pollution \\
v29 & v29 & membership of environmental organization \\
\hline
\end{tabular}

\subsubsection{Other Data}

In addition to the World Value Survey data, other data have been used in our study. Water-related data, such as the water consumption per capita, water resource availability, water prices and provincial-level socio-economic demographic data are collected from Chinese statistical yearbooks (1991, 1996, 2002 and 2008), provincial statistical yearbooks (1991, 1996, 2002 and 2008), the China Urban Construction Statistical Yearbook (2002 and 2008), and the China Statistic Yearbook on Environment (2002 and 2008); detailed information for each variables is presented in section 5 .

\section{$5.5 \quad$ Variables}

\subsubsection{Dependent Variables}

In this study, we use three environmental concern indictors as dependent variables instead of using water consumption behavior variables; the dependent variables correspond to the three environmental concern components identified in the literature. Our choice is mainly a result of the limited access to sufficient data related to water concerns, as water conservation behavior questions were not included in every WVS. Among all of the available World Value Survey data, selfreported water conservation behavior data are only available in the 1995 survey. Table 5.2 gives the detail information of each variable. Through quantitative pairwise correlation test, we show that the environmental concern indicators are strongly linked to water consumption behavior among citizens (Table 5.5). 
Table 5.5: Pairwise correlation of the water conservation behavior variable and environmental concern variables

\begin{tabular}{|c|c|c|c|c|c|c|c|c|c|c|}
\hline pwcorr & v44 & v38 & v39 & $\mathrm{v} 40$ & $\mathrm{v} 42$ & v43 & v33 & v45 & v46 & $\mathrm{v} 49$ \\
\hline $\mathrm{v} 44$ & 1 & & & & & & & & & \\
\hline v38 & 0.0488 & 1 & & & & & & & & \\
\hline sig & 0.0797 & & & & & & & & & \\
\hline v39 & 0.0089 & 0.3193 & 1 & & & & & & & \\
\hline sig & 0.7547 & 0.0000 & & & & & & & & \\
\hline v41 & -0.0570 & 0.1123 & 0.0678 & 0.0217 & & & & & & \\
\hline sig & 0.0467 & 0.0001 & 0.0196 & 0.4744 & & & & & & \\
\hline $\mathrm{v} 42$ & 0.1835 & 0.0651 & 0.0393 & -0.0250 & 1 & & & & & \\
\hline sig & 0.0000 & 0.0208 & 0.1754 & 0.4107 & & & & & & \\
\hline $\mathrm{v} 43$ & 0.2934 & -0.0053 & 0.0181 & -0.0420 & 0.2915 & 1 & & & & \\
\hline sig & 0.0000 & 0.8490 & 0.5280 & 0.1634 & 0.0000 & & & & & \\
\hline v33 & 0.0673 & 0.0547 & -0.0192 & -0.0305 & 0.0879 & 0.0780 & 1 & & & \\
\hline$\underline{\text { sig }}$ & 0.0126 & 0.0425 & 0.4886 & 0.2981 & 0.0012 & 0.0039 & & & & \\
\hline $\mathrm{v} 45$ & 0.0787 & 0.0070 & 0.0522 & -0.0740 & 0.0659 & 0.0691 & 0.1263 & 1 & & \\
\hline sig & 0.0043 & 0.8039 & 0.0692 & 0.0145 & 0.0190 & 0.0125 & 0.0000 & & & \\
\hline $\mathrm{v} 46$ & 0.0989 & 0.0824 & 0.0437 & -0.0246 & 0.1389 & 0.1139 & 0.1060 & 0.1447 & 1 & \\
\hline sig & 0.0003 & 0.0031 & 0.1252 & 0.4129 & 0.0000 & 0.0000 & 0.0001 & 0.0000 & & \\
\hline $\mathrm{v} 49$ & -0.0055 & -0.1032 & -0.0600 & 0.0590 & -0.0090 & -0.0277 & -0.0031 & 0.0099 & 0.0278 & 1 \\
\hline sig & 0.8453 & 0.0003 & 0.0374 & 0.0515 & 0.7535 & 0.3300 & 0.9117 & 0.7292 & 0.3289 & \\
\hline
\end{tabular}

The pairwise correlation test shows that the water conservation behavior variable (v44) is positively correlated with all of the environmental concern variables except for variables v41 and v49. The variable v49 is not correlated with the water conservation behavior variable $\mathrm{v} 44$. Whereas the variable $\mathrm{v} 41$ is negatively correlated with variable v44. This negative correlation might be caused by the development stage of China in 1995. Specifically, the majority of citizens who selfreported water conservation behavior prioritized economic development over environment protection. According to the survey data, 795 interviewees ${ }^{19}$ reported water conservation behavior in the past 12 months. Among them, 309 claimed that they believed environment protection was more important than economic development. Another 433 interviewees reported water conservation behavior but claimed that the priority should be given to economic development if environmental protection conflicted with economic development. The remaining 53 interviewees did not answer the question. Therefore, at least $56.6 \%$ of interviewees who reported water conservation behavior might have performed so for economic or other reasons rather than environmental protection. Nevertheless, 39\% of interviewees who performed water conservation behavior also thought that environmental protection was more important than economic development, which indicates that the economic motive was higher than the desire for environmental protection, so it became the main inducement of water conservation behavior in 1995 in China.

${ }^{19}$ In total, there are 1500 valid survey samples. 
Subsequent to economic development and an increased environmental concern among Chinese citizens, we believe that the total number of citizens practicing water conservation behavior will increase and that the dominant motivation for water conservation behavior will shift from economic reasons to that of environmental protection. Unfortunately, the WVS did not ask questions pertaining to water conservation behavior in the other years that were surveyed; however, we expect that they may include such questions in the coming surveys, which will enable us to further examine the relationship between water conservation behavior and its motivations.

Although we could not use the WVS data to prove our hypothesis, we attempt to show the evolution of the water consumption behavior trends with other provincial/city-level data from China. In 2011, the Doshisha University conducted environmental surveys in two cities in China, Beijing and Hangzhou. Although these two cities did not represent the general urban areas in China, the results illustrated the direction of water conservation behavior trends.

In Beijing, 1000 citizens were interviewed, and 94.1\% reported that they performed water conservation behavior in the past year. Among all of the interviewees who reported water conservation behavior, $56.3 \%$ claimed that the reason for saving water was for environmental protection, whereas only $32.9 \%$ said that their behavior was based on economic considerations. In Hangzhou, 1011 citizens participated in the survey, and $84.7 \%$ of the interviewees reported water conservation behavior. Of the interviewees who reported water conservation behavior, $42.2 \%$ did it for environmental protection reasons, whereas $53.6 \%$ were motivated by economic reasons. Although the percentage of financially motivated water conservation behavior was still higher than the percentage motivated by environmental protection in Hangzhou, when the results were compared to the 1995 WVS data, we found an increasing trend of water conservation behavior motivated by reasons of environmental protection and a decreasing trend of financially motivated water conservation behavior in China. All of the facts show a strong correlation between environmental value and water conservation behavior. Thus, the correlation between environmental value and water conservation behavior might not be statistically significant and could be negative at earlier stage of development. However, in the long run and subsequent to economic development, environmental value will have a positive impact on water conservation behavior. Therefore, by linking water conservation behavior and environmental concern, we were able to add longitudinal insights to the urban water consumption behavior in China.

Based on the explanatory factor analysis, we defined three environmental concern indicators in our study: environmental value variable, environmental attitude variable and environmental action variable. The environmental action variable used in our study is self-reported environmental action. The definition of the three environmental concern indicators and the corresponding variable codes are presented in Table 5.6 and Table 5.7. 
Table 5.6: Indicators of environmental concern

\begin{tabular}{ll}
\hline Independent variables & Definition and notes \\
\hline Environmental Value & The interviewee's value of the environment and nature \\
Environmental Attitude & $\begin{array}{l}\text { The attitude of the interviewee towards environmental problems and proactive } \\
\text { intentions to contribute to environmental protection }\end{array}$ \\
Environmental Action & The interviewee self-reported environmentally friendly actions \\
\hline
\end{tabular}

Table 5.7: Corresponding variable codes for indicators of environmental concern

\begin{tabular}{lllll}
\hline Variable name & \multicolumn{4}{l}{ Variable code in the surveys } \\
\cline { 2 - 5 } & 1990 & 1995 & 2001 & 2007 \\
\hline Environmental Value & $\mathrm{v} 15, \mathrm{v} 16, \mathrm{v} 17$ & $\mathrm{v} 41, \mathrm{v} 49$ & $\mathrm{v} 36, \mathrm{v} 37$ & $\mathrm{v} 88, \mathrm{v} 104$ \\
Environmental Attitudes: & $\mathrm{v} 12, \mathrm{v} 13, \mathrm{v} 14$ & $\mathrm{v} 38, \mathrm{v} 39, \mathrm{v} 42$ & $\mathrm{v} 33, \mathrm{v} 34, \mathrm{v} 35$ & $\mathrm{v} 105, \mathrm{v} 106, \mathrm{v} 107$ \\
Willing to Pay & & & & $\mathrm{v} 29$ \\
Environmental Action & $\mathrm{v} 26, \mathrm{v} 44$ & $\mathrm{v} 33, \mathrm{v} 43, \mathrm{v} 44, \mathrm{v} 45, \mathrm{v} 46$ & $\mathrm{v} 46, \mathrm{v} 61$ & $\mathrm{~V}$ \\
\hline
\end{tabular}

\subsubsection{Independent Variables}

The independent variables at the group and individual levels in our models are defined in Table 5.8 and Table 5.9, respectively. These variables control differences at the individual and group levels. All of the data for the individual-level independent variables are obtained from the World Value Survey, whereas the data for the group-level independent variables are mainly drawn from different Chinese statistical yearbooks.

Table 5.8: Group-level independent variables

\begin{tabular}{ll}
\hline $\begin{array}{l}\text { Group-level } \\
\text { independent variables }\end{array}$ & Definition and notes \\
\hline $\begin{array}{l}\text { GDP per capita } \\
\text { Urbanization }\end{array}$ & $\begin{array}{l}\text { Logarithm of the GDP per capita in each province } \\
\text { The percentage of population living in urban areas in each province } \\
\text { Population Density }\end{array}$ \\
$\begin{array}{l}\text { Population density in urban areas in each province measured by persons per } \\
\text { square kilometers }\end{array}$ \\
Gini coefficient & Gini coefficient that measures the inequality of incomes in each province \\
\hline
\end{tabular}

Table 5.9: Individual-level independent variables

\begin{tabular}{|c|c|}
\hline $\begin{array}{l}\text { Individual-level } \\
\text { independent variables }\end{array}$ & Definition and notes \\
\hline Gender & Gender of interviewee: 1 -male and 2-female \\
\hline Age & Logarithm of interviewee's age \\
\hline Education & $\begin{array}{l}\text { Education level: 1- less than primary school, 2-primary school, 3-middle } \\
\text { school, 4-high school, 5-university and higher education }\end{array}$ \\
\hline Employment status & $\begin{array}{l}\text { Employment status: } 0 \text {-unemployed, 1-student, 2-housewife, 3-retired, 4-self- } \\
\text { employed, 5-part time job, } 6 \text { full time job, 7- others }\end{array}$ \\
\hline Income & $\begin{array}{l}\text { Logarithm of the mean value of personal annual income reported by the } \\
\text { interviewee }\end{array}$ \\
\hline Financial satisfaction & $\begin{array}{l}\text { Satisfaction for the interviewee's financial condition: } 1 \text {-not satisfied at all to } \\
10 \text {-very satisfied }\end{array}$ \\
\hline
\end{tabular}




\begin{tabular}{ll}
\hline $\begin{array}{l}\text { Individual-level } \\
\text { independent variables }\end{array}$ & Definition and notes \\
\hline Trust & Trust of other people in the society: 1-trust, 0-not trust \\
Geographical pride & $\begin{array}{l}\text { Pride for the cities/provinces where the interviewee lives: 2-pride both for city } \\
\text { and province, 1-only pride for either city or province, 0-no pride at all }\end{array}$ \\
\hline
\end{tabular}

\subsection{Results}

In this study, we examined water conservation behavior and environmental concern in Chinese urban areas based on four waves of WVS data (1990, 1995, 2001 and 2007). Our main interest is water conservation behavior and its determinants. However, as a result of data accessibility issues, we have used environmental concern to connect water consumption behavior with socio-economic demographic factors to investigate the determinants of water conservation behavior in urban areas in China. As the four waves of WVS were done separately and different citizens were interviewed in each survey, we could not construct panel dataset to examine the evolution of environment concern among Chinese citizens, instead, we first examine each wave data separately and then compare the results from the different waves. Through this approach, we are able to develop a better understanding of the determinants of water conservation behavior in China over the past three decades.

Environmental concern is represented by three hierarchical environmental concern indicators that comprehensively show the different dimensions of environmental concern. By identifying the determinants of environmental concern, we investigate the impact factors of water conservation behavior in urban areas in China for the period 1990-2007. Our work has the potential to provide valuable information for environmental policy-makers, especially water authorities, for evaluating previously implemented policies and for designing new policies to improve environmental performance in China.

All of the regression results of our multilevel regression models are shown in Tables 5.10 to 5.26. In each table, we present the following models: intercept only, fixed effect, fixed effect with group-level variables, random coefficient and full multilevel regression. The results are presented separately for each environmental concern indicator based on the standardized data. Standardized regressions (centered results) are run to obtain meaningful comparable coefficients. The GDP per capita, urbanization, population density and income inequality are controlled at the group level. As a result of multi-collinearity, we could not control the coefficients in one model; therefore, we control them separately. Because it is one of the most important group-level control variables, the GDP per capita is presented in the results even if its coefficient is not statistically significant. For the rest of the group-level control variables, we only present the results with statistically significant coefficients ${ }^{20}$.

${ }^{20}$ Additional results are available upon request. 
Each environmental concern indicator is discussed with its chronological sequences. The GDP per capita is the most important group-level control variable in this study; therefore, the relative results are discussed separately at end of this section. The estimate of the first-level residual error variance shifted from the null model to the full multilevel regression model for all of the regression analyses in the four observational periods, which implies that each higher-order model fits the data better than the previous model. Moreover, the estimate of the variance of the random intercept at the regional level shifted from model 1 to model 4 for every indicator in all of the observational periods, which implies that the environmental concern indicators could be better explained with the addition of regional-level control variables. To further investigate the group-level variable effects on the environmental concern variables, we introduce the quadratic GDP per capita into the fixed effect model with group-level variables, which enriches our research with extra information. The GDP per capita and environmental concern indicators are further discussed in section 5.6.4.

\subsubsection{Determinants of Environmental Value}

Environmental value is the cognitive component of environmental concern, which is the basis of the environmental concern hierarchy. Table 5.10 reports the results of multilevel regression analyses on the environmental value indicator for the period 1990. The results show that there are three variables characterized by a statistically significant positive relationship with the dependent variables gender, education and trust. The coefficients of gender and trust are statistically significant at the $10 \%$ level, whereas the coefficient of education is statistically significant at the $1 \%$ level. Therefore, education had the strongest positive influences on the formation of environmental values in 1990 in China, which is consistent with the literature. Geographical pride is negatively correlated with environmental value and is statistically significant at the $5 \%$ level. The coefficients of remaining independent variables are not statistically significant. At the group level, none of four group-level control variables has statistically significant correlations with environmental value.

Table 5.11 shows the results of the multilevel regression analyses of environmental value for the 1995 WVS Chinese data. Gender and age are negatively correlated with environmental value and are statistically significant at the $10 \%$ level and $1 \%$ level, respectively. None of the remaining independent variables at the individual or group level has statistically significant correlations with environmental value in 1995.

The regression results of the 2001 WVS Chinese data are shown in Table 5.12 and Table 5.13. Similar to the results of the 1995 data, age is negatively correlated with environmental value and is statistically significant at the $1 \%$ level. Financial satisfaction is positively correlated with environmental value and is significant at the $10 \%$ level for the fixed-effects model, the fixed-effect model with group-level 
variables and the random coefficient model and is significant at the $5 \%$ level for the full multilevel regression model. In the full multilevel regression model, the interaction term GDP per capita*age is positively correlated with the dependent variable, which implies that the age effects increased by 2.332 with a one unit increase of the GDP per capita. Therefore, in provinces with a higher GDP per capita, the age effects will be greater.

Table 5.14 reports the results of the multilevel regression analysis for the 2007 WVS Chinese data. Trust, income and geographical pride are positively correlated with environmental value and are statistically significant at the $10 \%$ level. Education is positively correlated with environmental value for the fixed-effects model and the fixed-effects model with group-level variables and is statistically significant at the $10 \%$ level. When random coefficients and interaction terms are included in the models, the statistical significance disappears.

In general, we do not find consistent determinants of environmental value over the four observational periods. Gender is positively correlated with environmental value and is statistically significant in 1990, whereas it is negatively correlated with environmental value and is statistically significant in 1995. In 2001 and 2007, gender effects disappear, which means that gender does not correlate with environmental value for the later periods. This result implies that at the earlier stage of the observational periods, women and men possessed different levels of environmental value. Women were more concerned for children and daily life; therefore, they might have expressed high environmental concern, which is reflected in 1990. However, men obtained environmental knowledge through social activities, and after the dissemination of environmental knowledge, they became more environmentally concerned in 1995. Subsequent development reduces the gender difference to zero for later observational periods. 


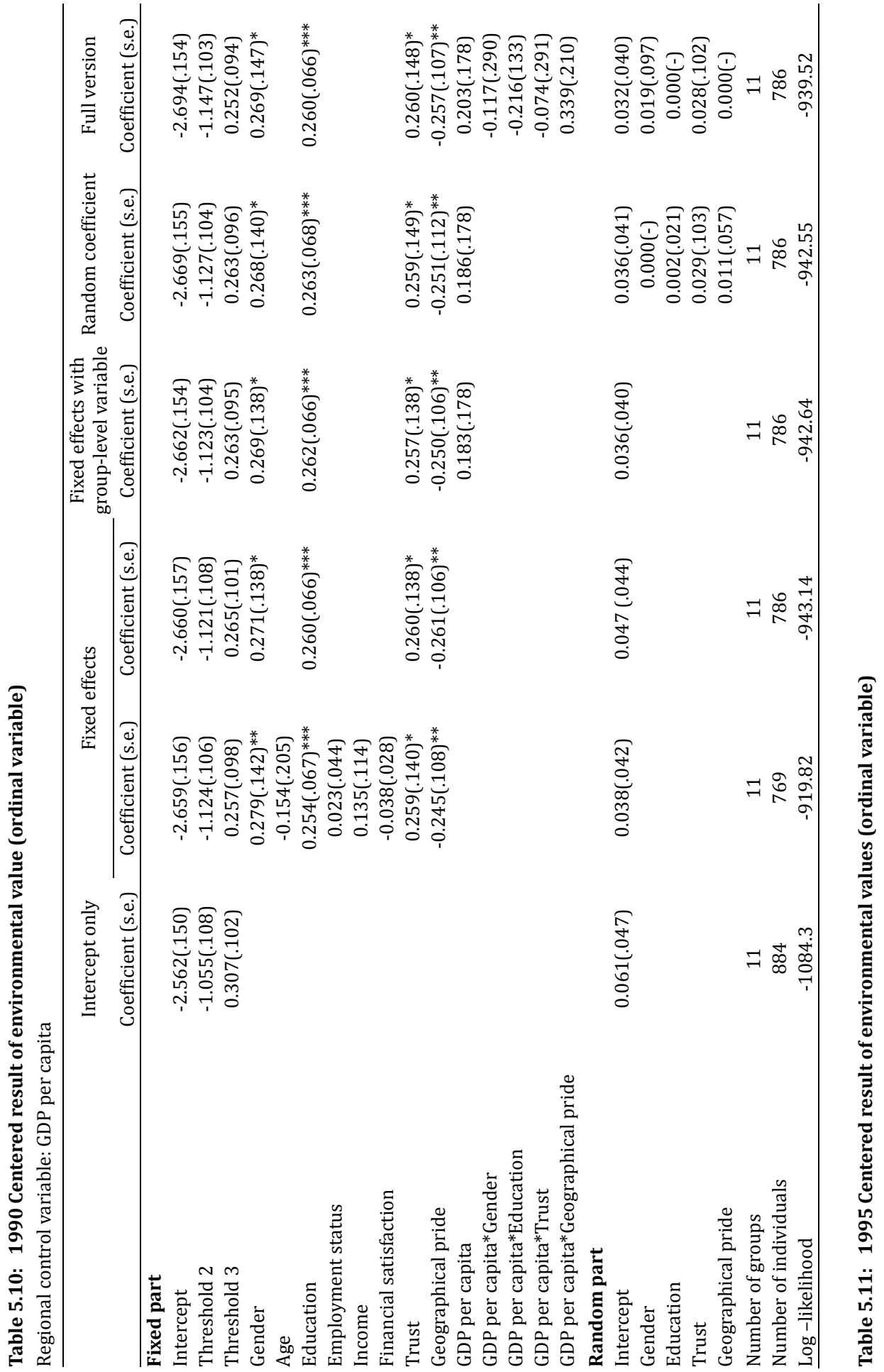




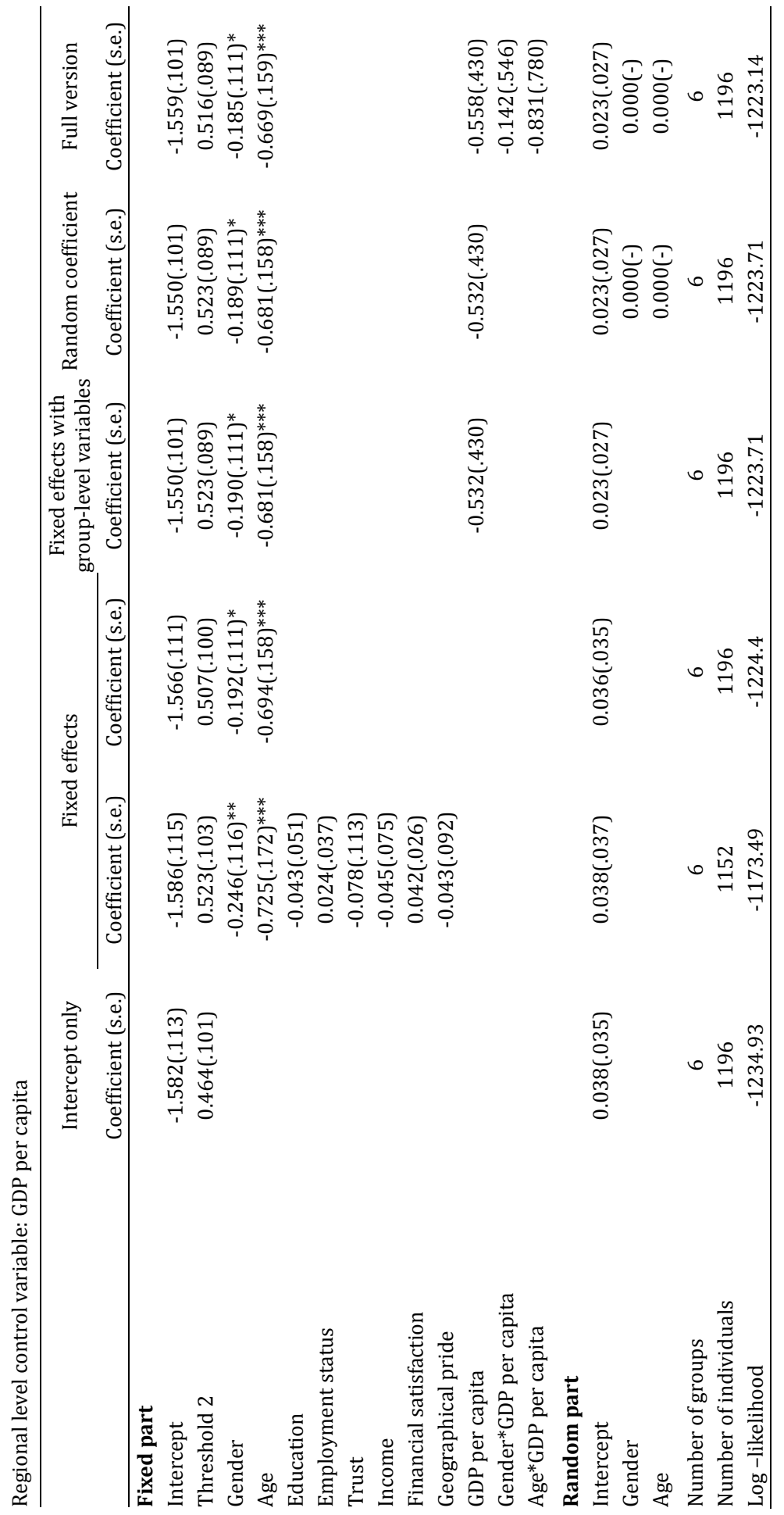




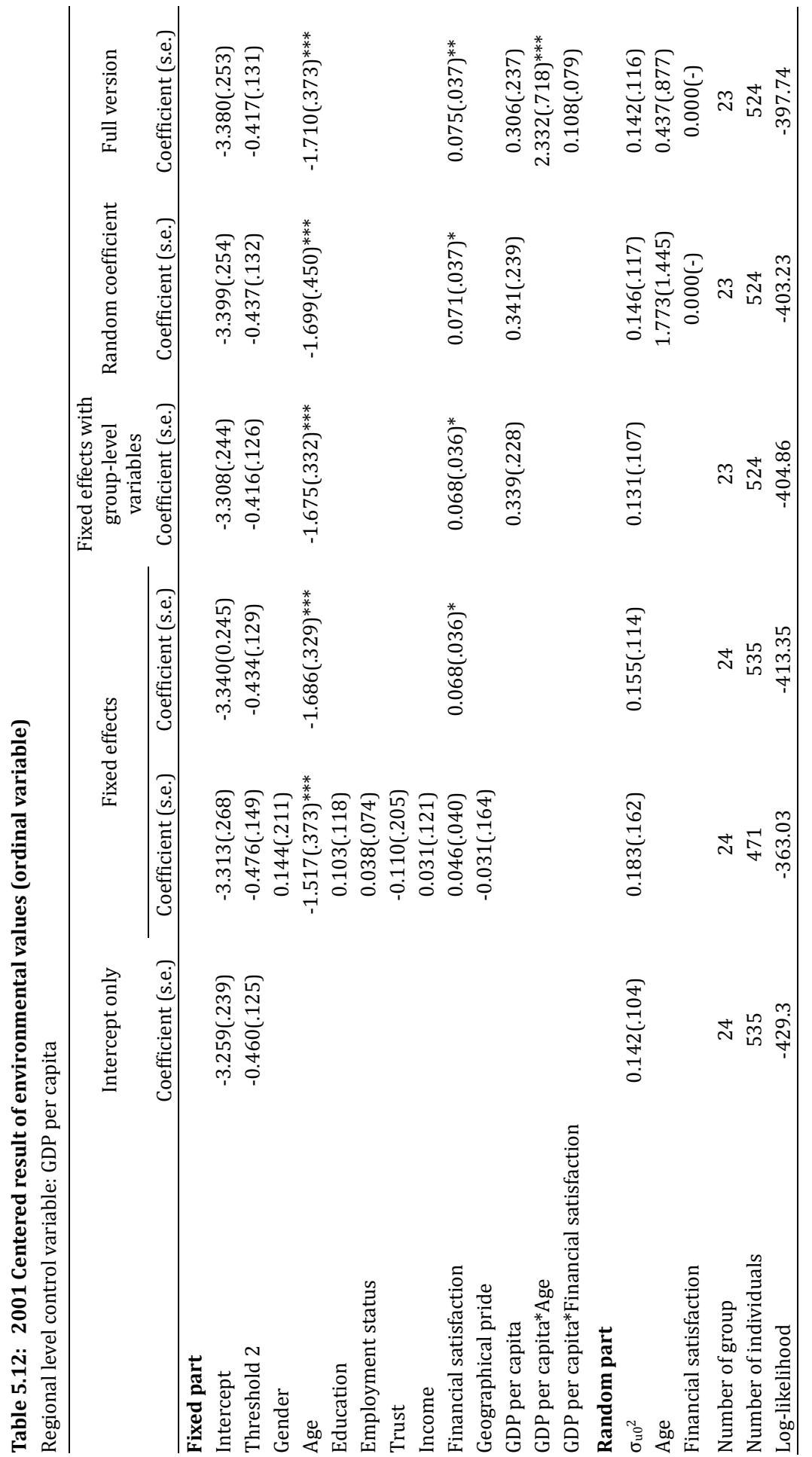




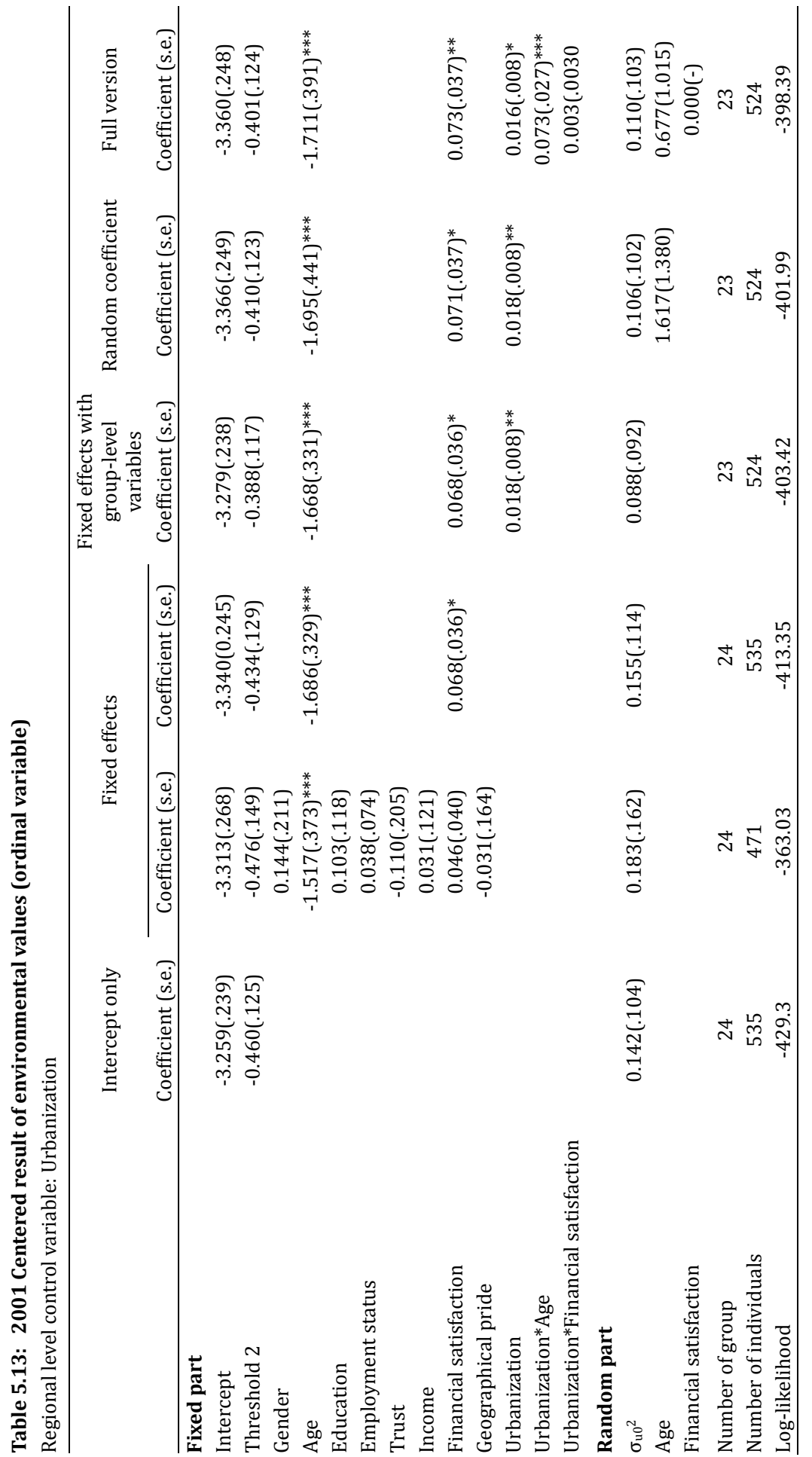




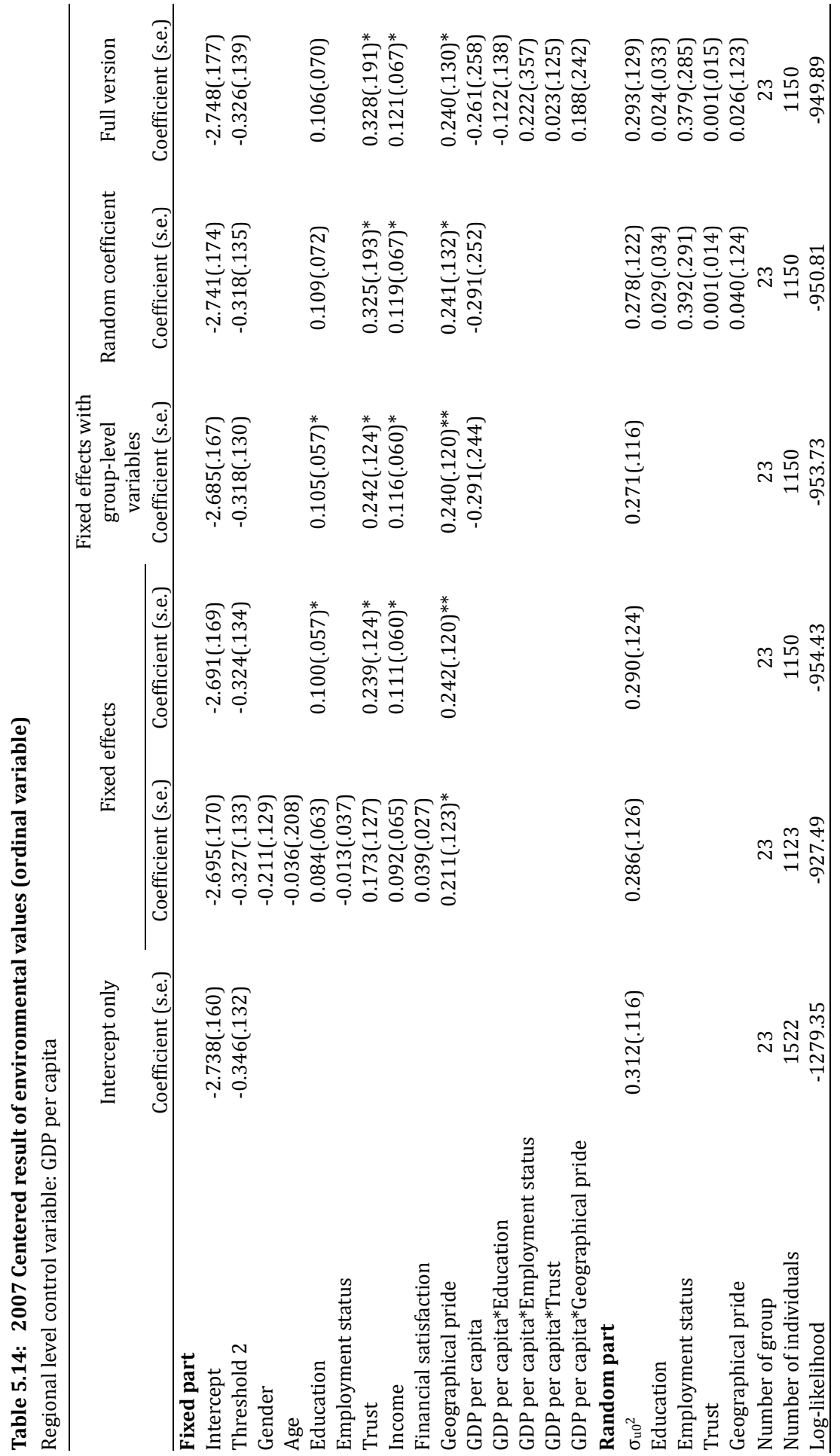


Age is characterized by a negative relationship with environmental value in 1995, 2001 and 2007, but only statistically significant in 1995 and 2001. This result is consistent with the literature, wherein younger citizens are suggested to be more concerned for the environment than the aging population. In 2007, the age effects are not statistically significant, which might have been caused by a shift in age of the population. It might also have been caused by environmental propaganda targeted to the aging population, which leads to them having increased environmental concern.

Education is strongly correlated with environmental value in 1990 but weakly correlated with environmental value in 2007. The results show that the coefficients of education in 2007 are only statistically significant for the fixed-effects model and the fixed-effects model with group-level variables. For 1995 and 2001, we do not observe a correlation between education and environmental value. Therefore, we argue that education effects are not significant in the observational period in 1995 and 2001. The strong correlation in 1990 might have been a result of environmental knowledge only being partly disseminated; in such situations, highly educated people had increased access to environmental knowledge and a better understanding of it. However, the majority of citizens were unfamiliar with such concepts. Following the development and wide dissemination of environmental knowledge through different channels, all of the citizens could easily obtain environmental knowledge, which leads to a generally high environmental value among citizens, regardless of their education level.

Trust refers to social capital in a society. Our results show that trust is positively correlated with environmental value in China and statistically significant at the $10 \%$ level for 1990 and 2007. People who trust each other are more willing to share information and cooperate in a society. Theoretically, trust is more closely linked to environmental attitude and action. We also observe that trust has positive effects on environmental value, although the effects are not consistent over time in our dataset. Nevertheless, the result shows that trusted social relationships lead to a higher level of environmental value.

We find a negative correlation between environmental value and geographical pride in the 1990 WVS data, which is contrary to the literature and might have been caused by the level of development in China. In 1990, China was still at an earlier stage of development and had just initialized market-oriented reform. Environment protection is a new concept for most of the citizens at that time. Individuals with a higher level of geographical pride might have placed a higher emphasis on economic conditions and selected economic development as more important than environmental protection because economic development was the key measure and indicator of a region. This leads to the negative correlation between geographic pride and environmental value. Following the development, with the increase of wealth and environmental knowledge, citizens recognize the importance of environment protection for the local development and quality of life. They are aware that environment is one of the crucial indicators of their region. Therefore, people with a high degree of geographic pride will place a high value on 
the environment. Based on our hypothesis, we would expect to observe a positive correlation in the later periods, and the Chinese WVS data is consistent with our hypothesis. We observe negative coefficients of geographical pride in 1995 and 2001 , but they are not statistically significant. In 2007, we observe a positive correlation between geographical pride and environmental value.

At the group level, the GDP per capita, urbanization, population density and Gini coefficient are tested. The GDP per capita does not have a statistically significant effect on environmental value for any of the observational periods. Urbanization has negative effects on environmental value in 2007; however, the effects are not statistically significant for the other observational periods, which might have been a result of the short-term and long-term issues associated with the urbanization process as a massive population flows from rural areas to urban areas. For new urban inhabitants, additional time is required for them to gain local environmental knowledge and increase their level of environmental concern. Population density and the Gini coefficient variables do not have significant effects on environmental value for any of the observational periods in China.

\subsubsection{Determinants of Environmental Attitude}

Table 5.15 shows the regression results of the multilevel analyses of environmental attitude for the 1990 WVS Chinese data based on the standardized data. Education, financial satisfaction and trust are positively correlated with environmental attitude and statistically significant at the 5\%,1\% and $1 \%$ level, respectively. Employment status, income, and geographical pride are negatively correlated with environmental attitudes and statistically significant at the 5\%,1\% and $10 \%$ level, respectively. In the full multilevel regression model, the interaction term GDP per capita*trust is negatively correlated with environmental attitude. For one additional unit of GDP per capita, the effect of trust decreases by 0.067 in 1990 in China. Therefore, the provinces with higher GDP per capita have smaller trust effects.

Table 5.16 and Table 5.17 present the regression results for environmental attitude for the 1995 WVS Chinese data that are separately controlled for by the GDP per capita and urbanization at the regional level. Among all of the group-level control variables, only urbanization is negatively correlated with environmental attitude and it is statistically significant at the $10 \%$ level according to the full multilevel regression model. We retain the GDP per capita and urbanization variables as separately applied control variables for regional differences in the model. When the group-level control variable GDP per capita is applied, education, trust, income and financial satisfaction are positively correlated with environmental attitude and statistically significance at the 5\%,1\%,5\% and 5\% levels, respectively. Geographical pride is negatively correlated with the dependent variable and statistically significant at the $5 \%$ level. None of the remaining variables has statistically significant correlations with environmental attitude. In the full multilevel regression model, the interaction term of GDP per capita and financial satisfaction is negatively correlated with environmental attitude, which implies that for one 
additional unit of GDP per capita, the effect of financial satisfaction is decreased by 0.024 . Hence, provinces with higher GDP per capita have smaller financial effects. The interaction term of GDP per capita and trust is positively correlated with environmental attitude. For one additional unit of GDP per capita, the effect of trust is increased by 0.135 . This means that provinces with a higher GDP per capita have greater trust effects. Based on the negative correlation between the interaction term of GDP per capita*trust and environmental attitude in 1990, we argue that citizens with increased economic resources at earlier developmental stages may initially lose their social capital; however, after they recognize the importance of social capital, they will subsequently regain such capital.

For the 1995 WVS survey data, when urbanization is introduced as the group-level control variable, education, trust, income and financial satisfaction are positively correlated with environmental attitude. The coefficients of education, trust and income are statistically significant at the 5\% level, whereas the coefficient of financial satisfaction is statistically significant at the $1 \%$ level. Geographical pride is negatively correlated with the dependent variable and statistically significant at the $5 \%$ level. At the group level, the urbanization variable is negatively correlated with environmental attitude to a small degree because the coefficient is near zero, and it is statistically significant at the $10 \%$ level. In the full multilevel regression model, the interaction term of urbanization and financial satisfaction is negatively correlated with environmental attitude and is statistically significant at the $10 \%$ level, which means that for one additional unit of urbanization, the effect of financial satisfaction is decreased by 0.024 in 1995; therefore, more urbanized provinces have lower financial satisfaction effects. The interaction term of urbanization and trust is positively correlated with environmental attitude and statistically significant at the $5 \%$ level. Therefore, the effect of trust is increased by 0.139 with one additional unit of urbanization. Hence, the trust effects would be greater in well-urbanized regions.

Table 5.18 and Table 5.19 display the results of the 2001 WVS Chinese data, which are analyzed by the multilevel regression models with the group-level control variables of GDP per capita and urbanization using standardized data. The GDP per capita is included as a group-level control variable in Table 5.18. At the individual level, education and financial satisfaction are positively correlated with environmental attitude and are statistically significant at the $1 \%$ level. Age is characterized by a statistically significant negatively correlation with the dependent variable and is statistically significant at the $5 \%$ level. The remaining variables are not statistically correlated with environmental attitude. 


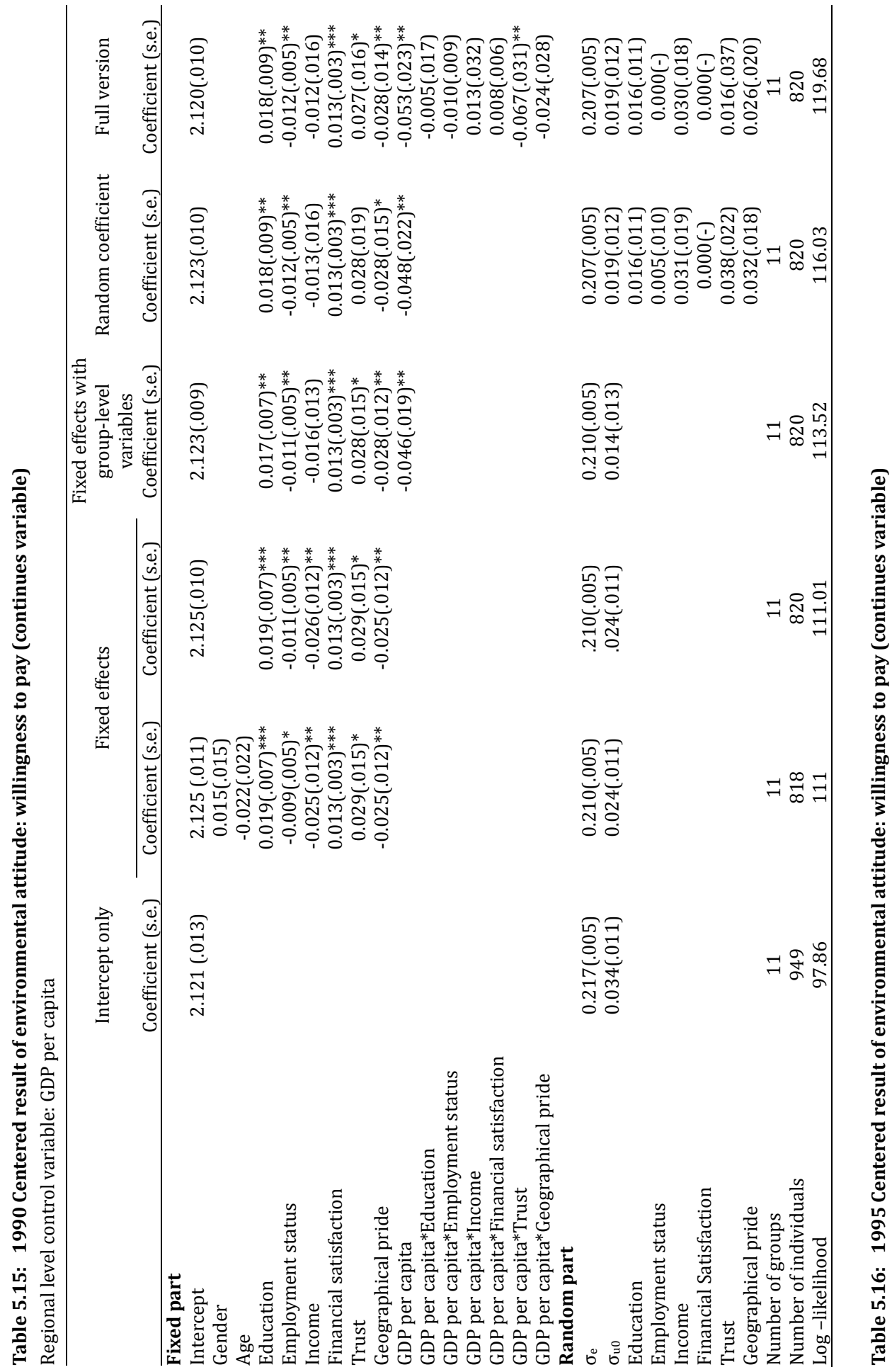




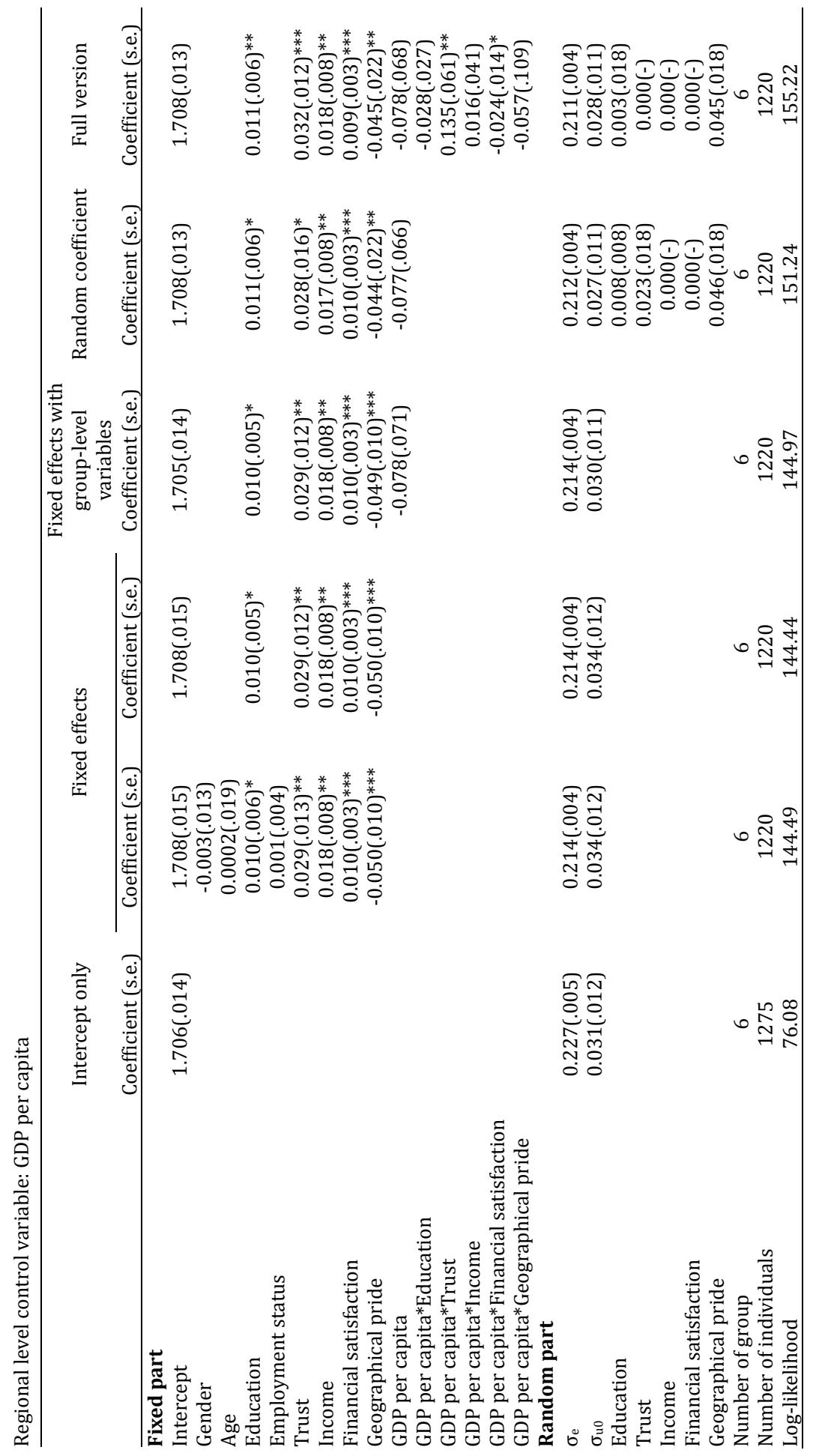




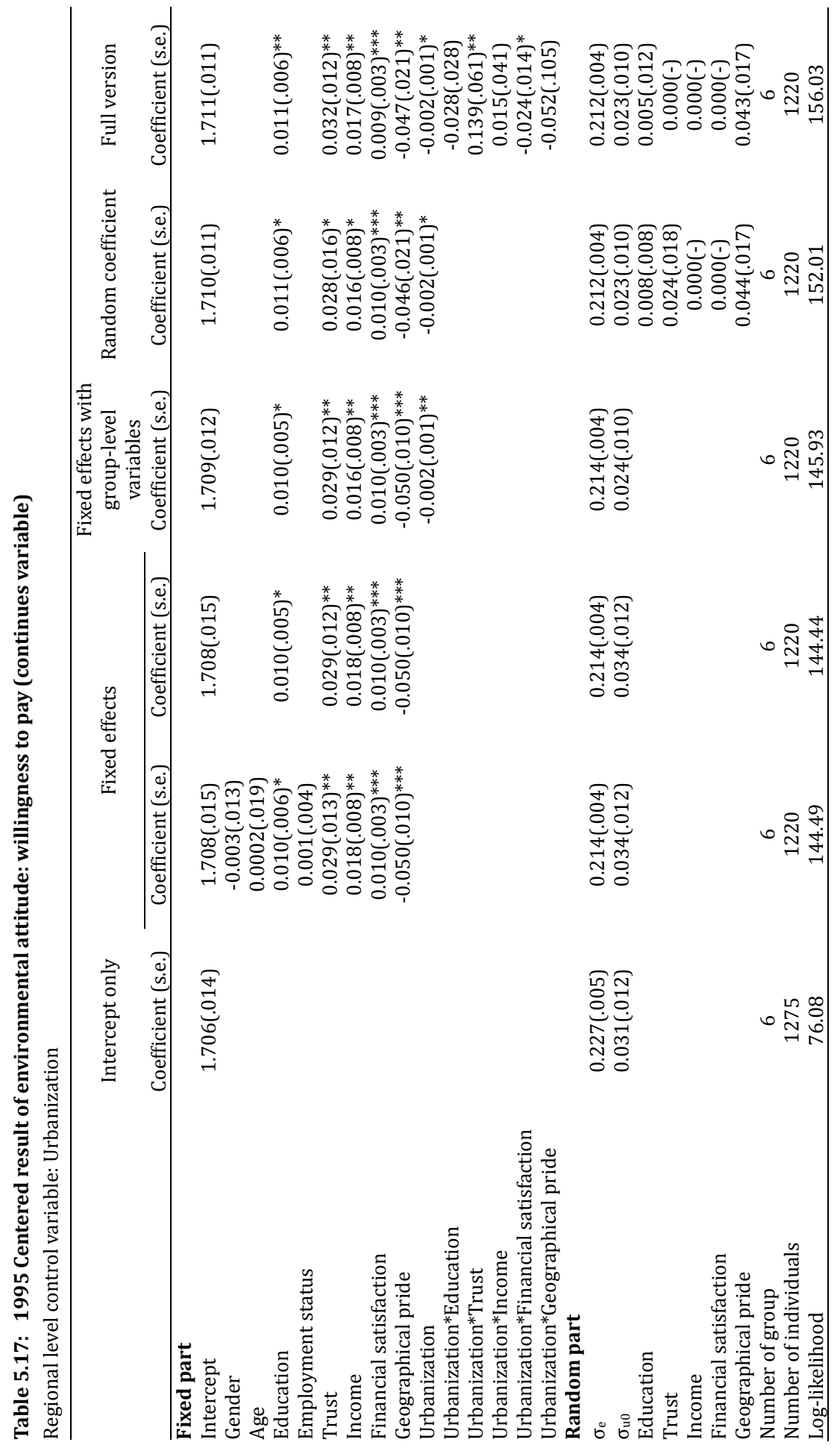


At the group level, the GDP per capita is negatively correlated with environmental attitudes and is statistically significant at the $10 \%$ level for the fixed-effects model with group-level control variables, the random coefficient model and the full multilevel regression model. None of the interaction terms in the full multilevel regression model are statistically correlated with environmental attitude. When urbanization is the control variable at the group level, similar results are found at the individual level. At the group level, urbanization is negatively correlated with environmental attitude and is statistically significant at the 5\% level. However, the coefficient of urbanization is small and nearly zero, which implies that the urbanization effects are weak. The interaction terms in the full multilevel regression model are not statistically significant.

The analysis results of the 2007 WVS Chinese data are presented in Table 5.20. At the individual level, education, trust, income and geographical pride are positively correlated with environmental attitude. The coefficients of education, trust and income are statistically significant at the $1 \%$ level, whereas the coefficient of geographical pride is statistically significant at the $10 \%$ level. No group-level control variable is statistically significant in the regression. In the full multilevel regression model, none of the interaction terms has a statistically significant correlation with environmental attitude.

A close examination of each independent variable over time shows that the coefficient of education is positively correlated with environmental attitudes for all of the observational periods, which implies that citizens with higher levels of education tend to express higher levels of environmental attitudes. Similar to the pattern in environmental value, gender effects are only statistically significant in 1990, which may be explained by a similar reason in which the dissemination of environmental knowledge increases the level of environmental attitude, which in turn reduces the gender difference. Trust is positively correlated with environmental attitude and is statistically significant in 1990, 1995 and 2007. This result is consistent with the literature, wherein high trust among citizens stimulates the formation of environmental attitudes. The geographic pride effect on environmental attitude is similar to its effect on environmental value. The coefficient of geographic pride changes from negative in 1990 to positive in 2007, and a similar argument as is made that its environmental value might also be applicable here. The coefficient of income also shifts from negative to positive in the four periods. In 1990, the negative correlation between income and environmental attitude might have been a result of the general low level of development in China. Although the group of high-income citizens have high levels of income compared with other citizens in the same area, their real income is still low overall. Therefore, they showed a lower intention of paying for environmental protection. Following development and an increase of real income in China in 2001 and 2007, citizens with higher income expressed a greater willingness to pay for environmental protection. Financial satisfaction contributes to the increase of environmental attitude because it is positively correlated with environmental attitude for all of the four periods and is statistically significant in 1990, 1995 and 2001. 


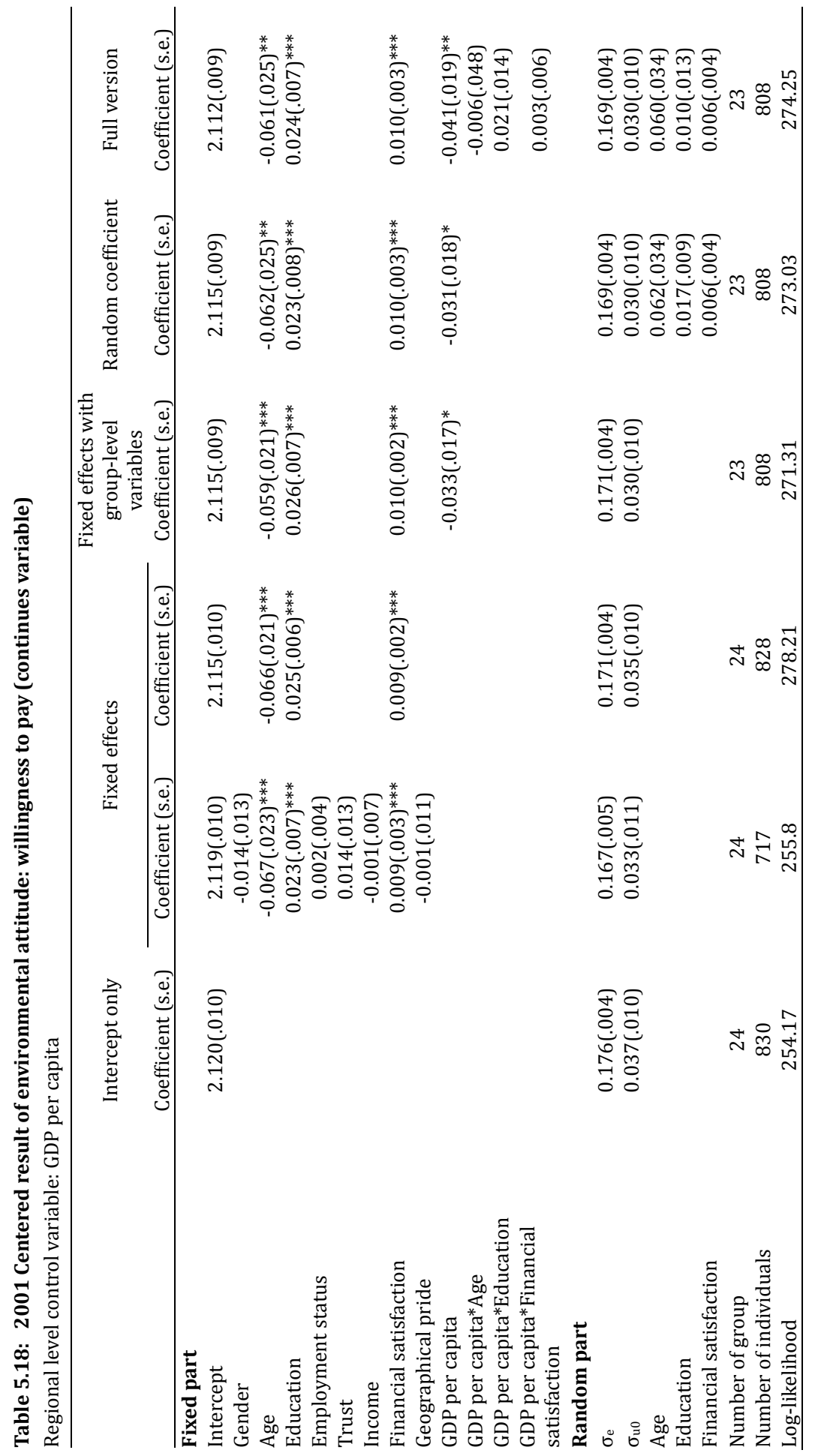




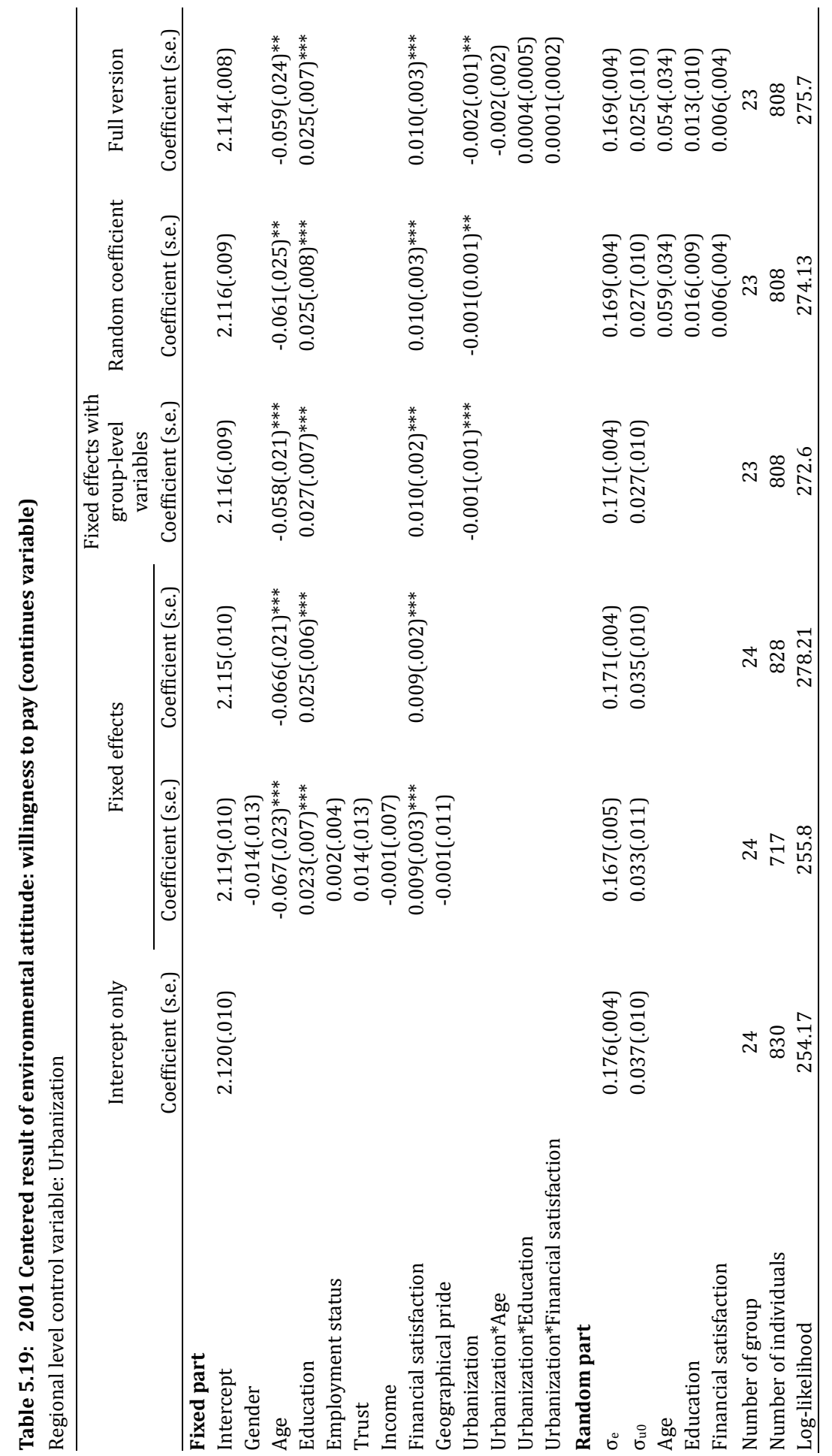




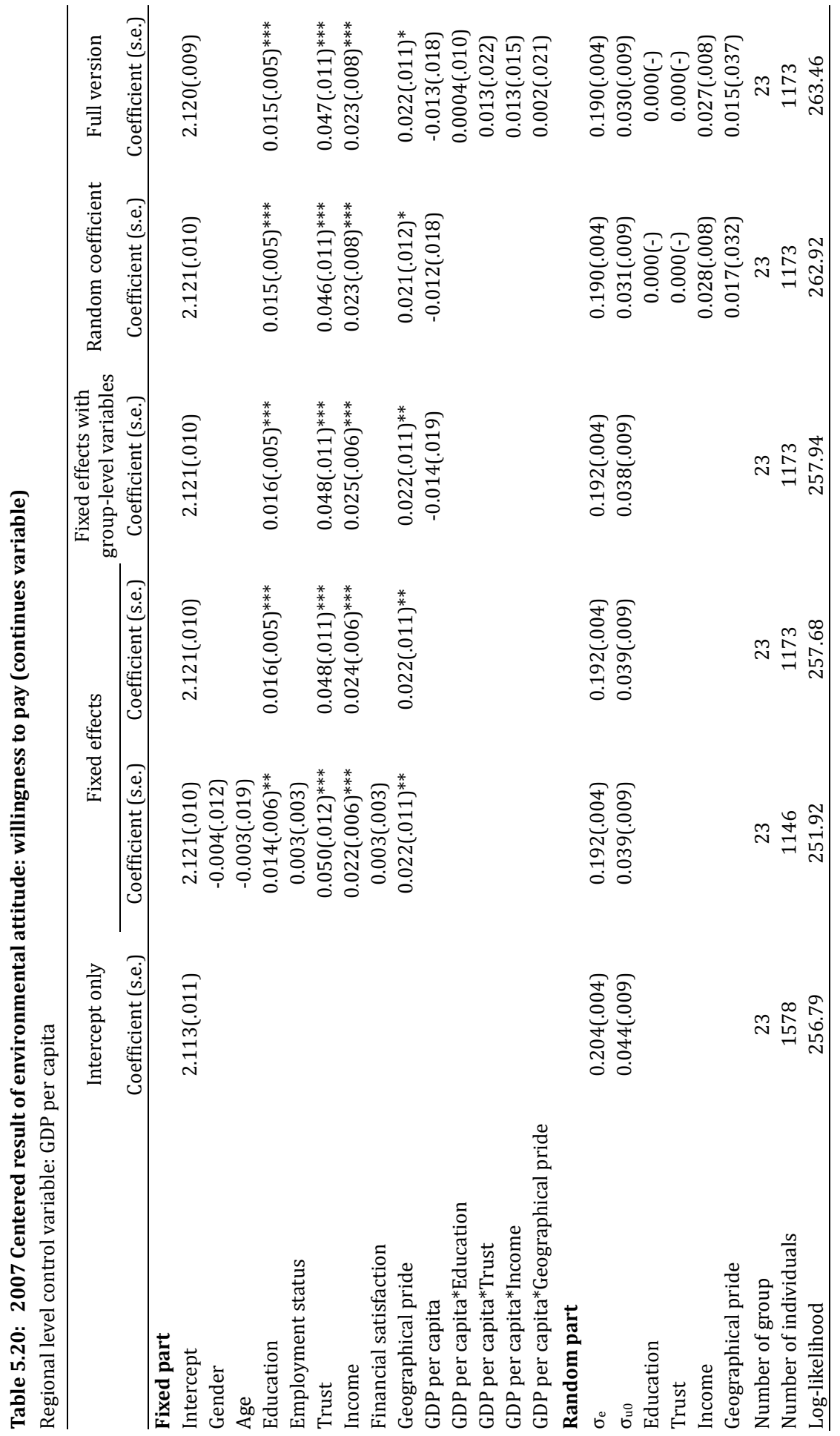


At the group level, the GDP per capita is not statistically correlated with environmental attitude for all of the periods. None of the other group-level control variable coefficients is statistically significant in the four observational periods.

\subsubsection{Determinants of Environmental Action}

Table 5.21 reports the regression results of the multilevel analyses of the 1990 WVS Chinese data with the dependent variable of environmental action. At the individual level, gender is negatively correlated with environmental action and was statistically significant at the $5 \%$ level. The coefficient of income is positive and was statistically significant at the $1 \%$ level. At the group level, we do not find any correlation between the group-level control variables and environmental action. We retain the GDP per capita as the group-level control variable in the model. In the full multilevel regression model, none of the interaction terms shows a statistically significant correlation with environmental action.

The regression results of the 1995 WVS Chinese data for environmental action are shown in Table 5.22. None of the group-level control variables shows a statistically significant correlation with environmental action. The GDP per capita is used as the group-level control variable for our investigation. At the individual level, education and financial satisfaction are positively correlated with environmental action and are statistically significant at the $1 \%$ and $5 \%$ level, respectively. Geographical pride is negatively correlated with the dependent variable and is statistically significant at the $10 \%$ level for the fixed-effects model only. In the full multilevel regression model, the interaction term GDP per capita*geographic pride is negatively correlated with environmental action and shows that for one additional unit of GDP per capita, the effect of geographic pride is decreased by 0.797 . Therefore, the geographic pride effects are more significant in poorer provinces than in high GDP per capita provinces.

Table 5.23 and Table 5.24 display the analysis results of the 2001 WVS Chinese data with the group-level control variables GDP per capita and urbanization, which are separately applied. Population density and the Gini coefficient are not statistically correlated with environmental action in 2001 in China. When the GDP per capital is controlled for at the group level, education and income are positively correlated with environmental action and are statistically significant at the 1\% level. The coefficients of other individual-level independent variables are not statistically significant in 2001. The GDP per capita is negatively correlated with environmental action and is statistically significant at the $10 \%$ level for the fixedeffects model with group-level control variables and the random coefficient model. In the full multilevel regression model, the coefficient of GDP per capita is also negative and is statistically significant at the $5 \%$ level. None of the interaction terms in the full multilevel regression model is statistically correlated with environmental action. When urbanization is controlled for as the group-level variable, similar results are found for the individual-level independent variables. At the group level, urbanization is negatively correlated with environmental action 
and is statistically significant at the $5 \%$ level, which shows that the urbanization in 2001 led to a decrease of environmental action in the urban areas in China.

The regression results of the 2007 WVS Chinese data are presented in Table 5.25 and Table 5.26 with the group-level control variables GDP per capita and Gini coefficient. When the GDP per capita is controlled for at the group level, education and income are positively correlated with environmental action and are both statistically significant at the $1 \%$ level. Financial satisfaction is positively correlated with environmental action but only for the fixed-effects model and the fixed-effects model with group-level variables, and they are both statistically significant at the $10 \%$ level. Age is negatively correlated with environmental action at the $1 \%$ level of statistical significance. At the group level, the GDP per capita is negatively correlated with environmental action and is statistically significant at the $10 \%$ level. In the full multilevel regression model, the interaction term GDP per capita*education is negatively correlated with environmental action and is statistically significant at the $1 \%$ level. Therefore, for one additional unit of GDP per capita, the effect of education is decreased by 0.732 . Hence, the education effect is relatively small in the provinces with higher GDP per capita. When the Gini coefficient is controlled for at the group level, similar results could be found for the individuallevel independent variables. At the group level, the Gini coefficient is negative and is statistically significant at the $5 \%$ level. None of the interaction term of the Gini coefficient shows a statistically significant correlation with environmental action in 2007.

For the four observational periods, the coefficients of gender are consistently negative but are only statistically significant in 1990. This implies that men performed more environmental actions than women in the observation period. However, following the dissemination of environmental knowledge and the increase of environmental attitudes among Chinese citizens, the gender gaps for environmental action became smaller and gradually disappeared. Education is positively correlated with environmental action for the four periods but is only statistically significant in 1995, 2001 and 2007, which may have been a result of citizens conducting environmental action with other motivations, such as financial reasons, in the earlier stages of development. Citizens might reduce their water usage and energy consumption just to save money. In such cases, we would not expect education to have a positive correlation with environmental action at earlier stages of development. However, we believe that the education effects will become more significant in later periods. The negative coefficient of age is only statistically significant in 2007, which shows that young citizens tended to conduct more environmental action than aging people in 2007. In the previous periods, age effects is not significant, which might have been a result of the generally low environmental actions among citizens. Income is positively correlated with environmental action in 1990, 2001 and 2007, which is consistent with the literature. Financial satisfaction is positively correlated with environmental action in 1995 and 2007, which implies that citizens who were more satisfied with their economic conditions tended to conduct more environmental actions. 


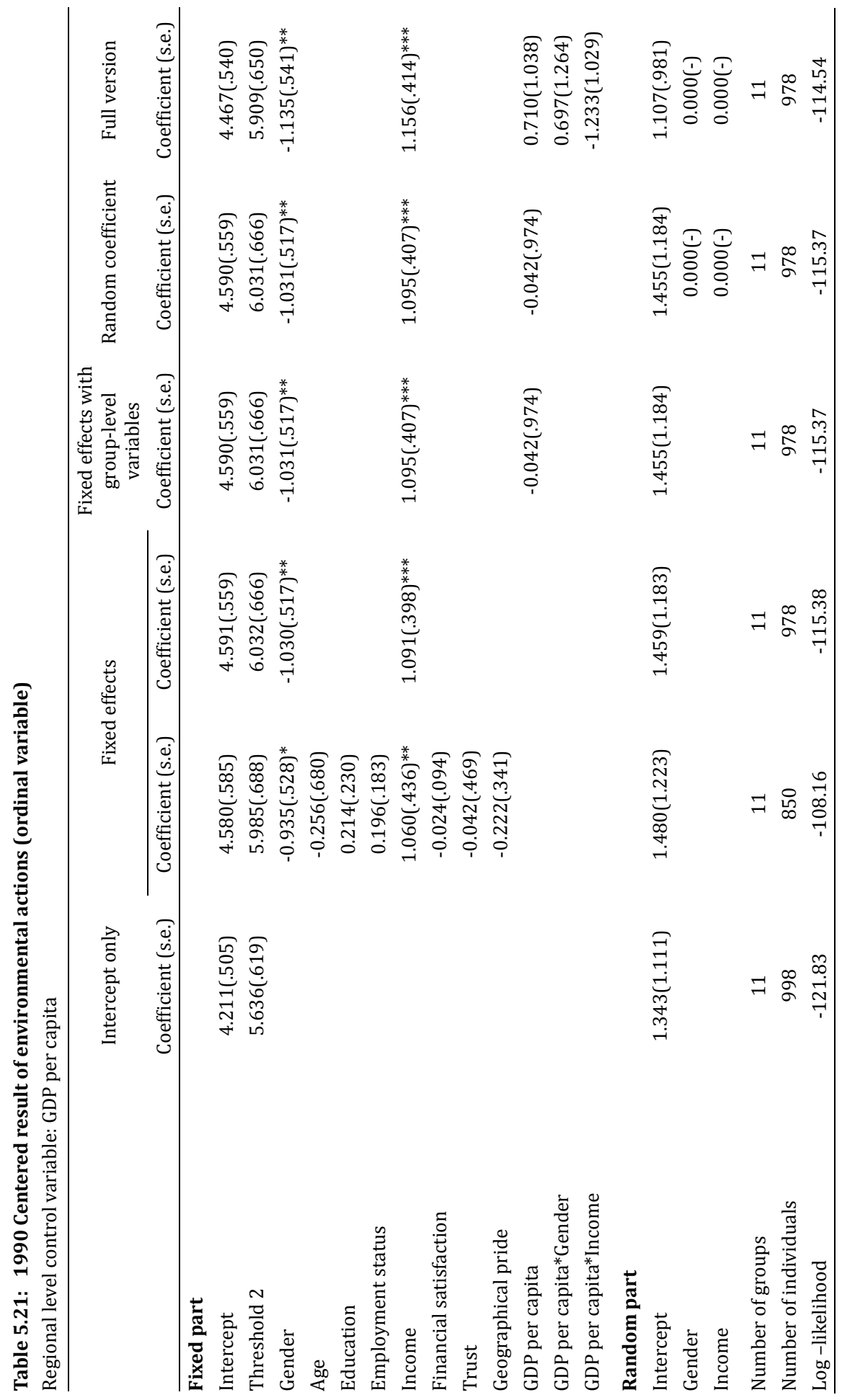




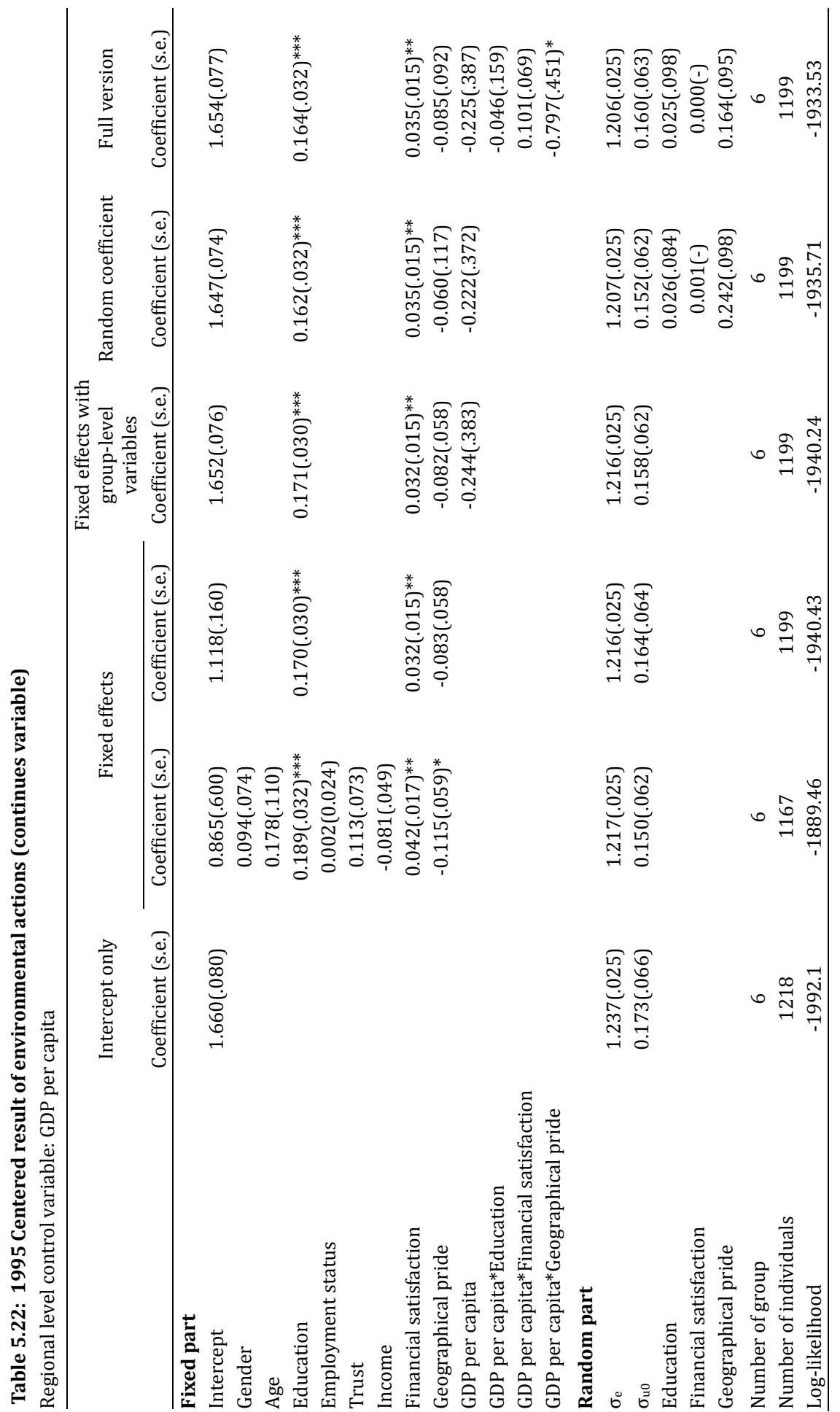




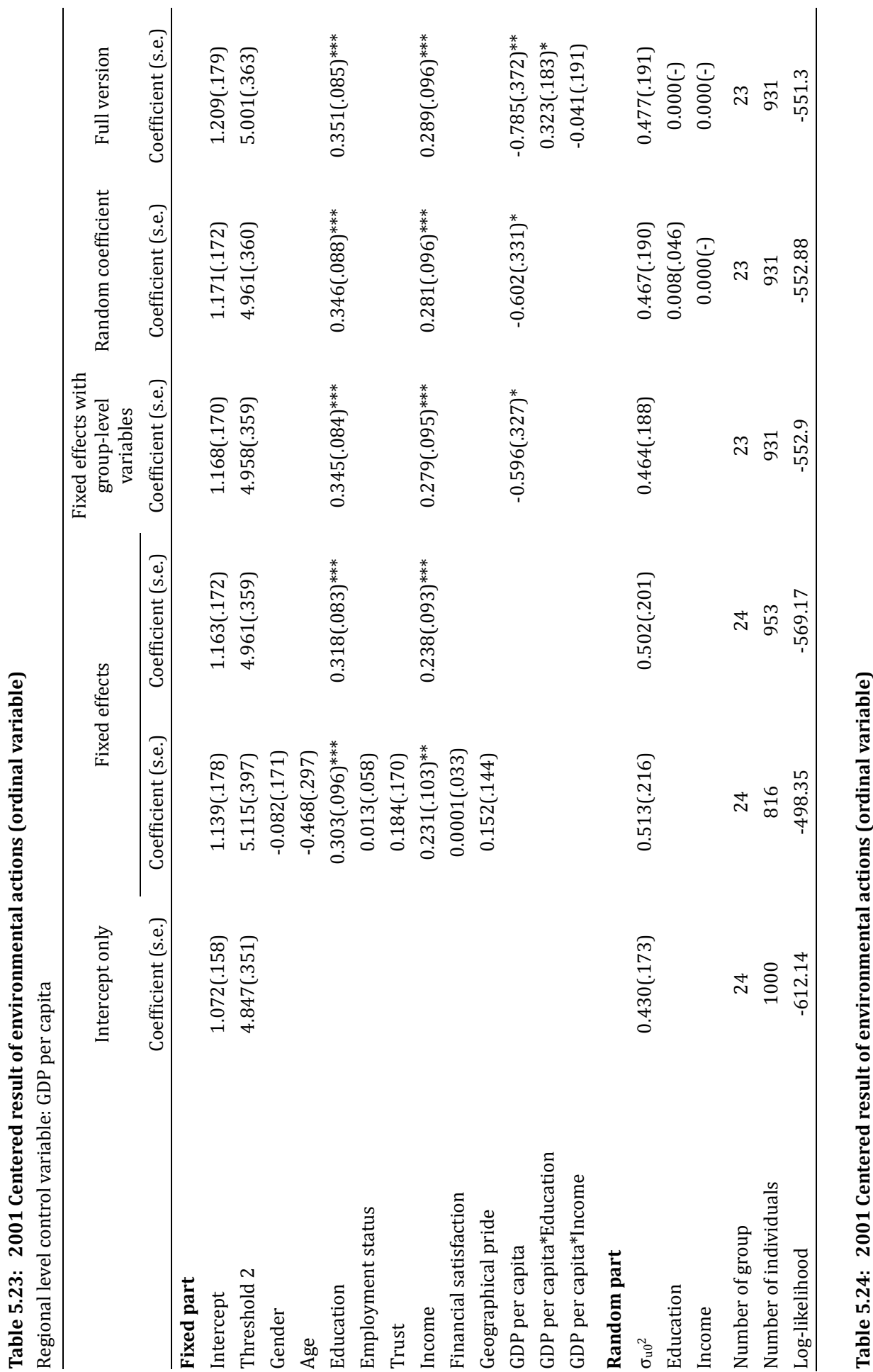




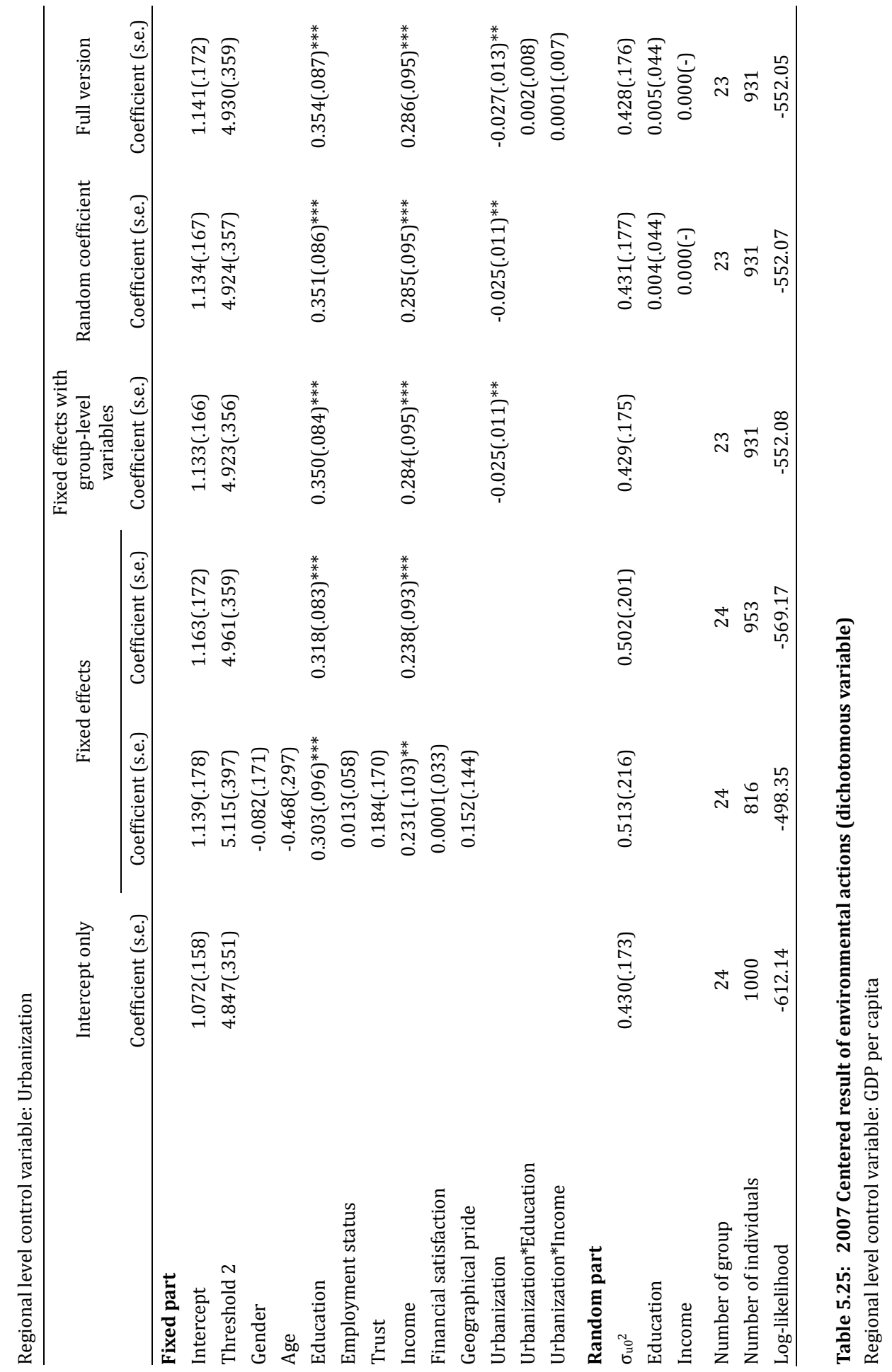




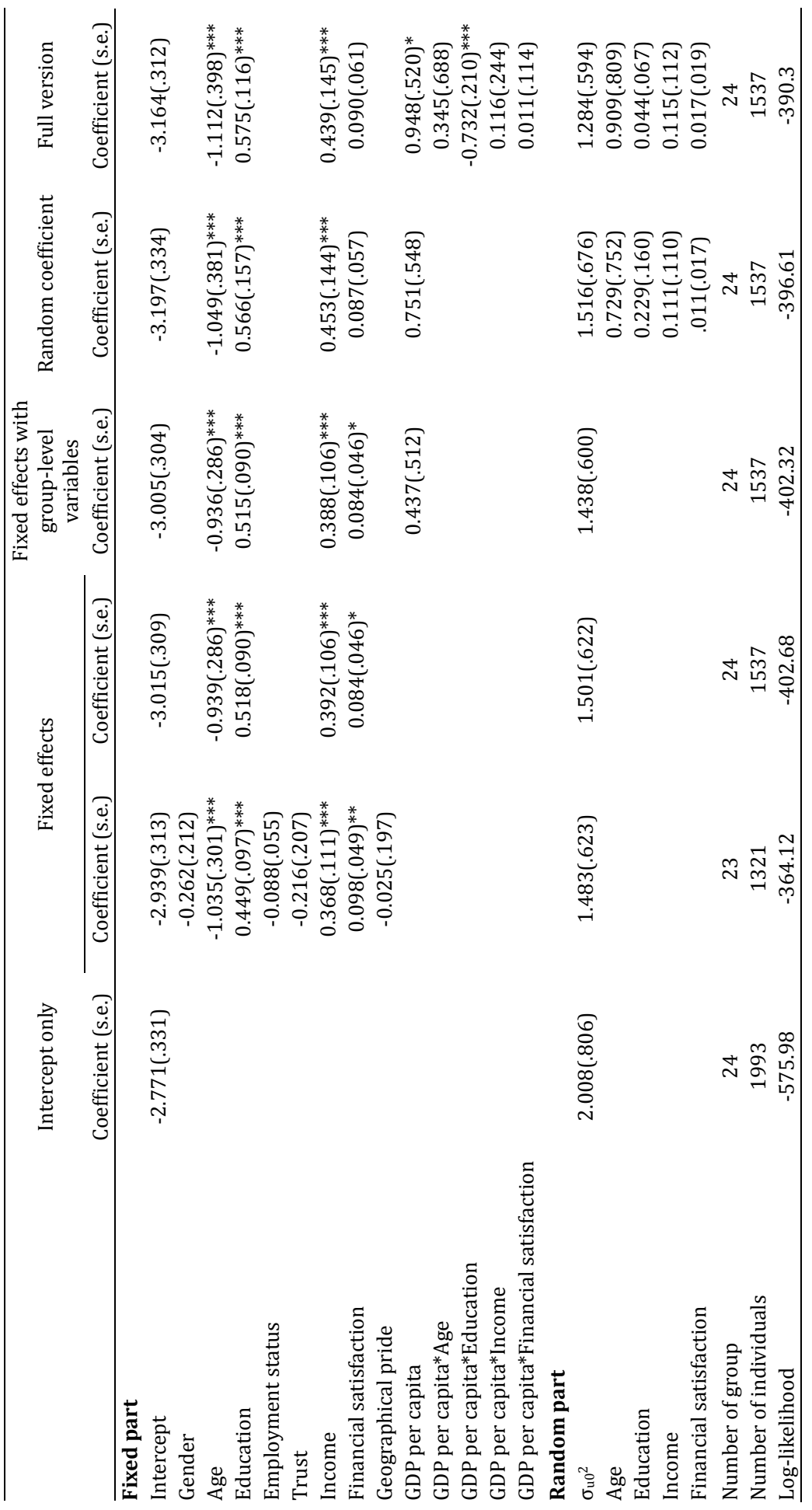




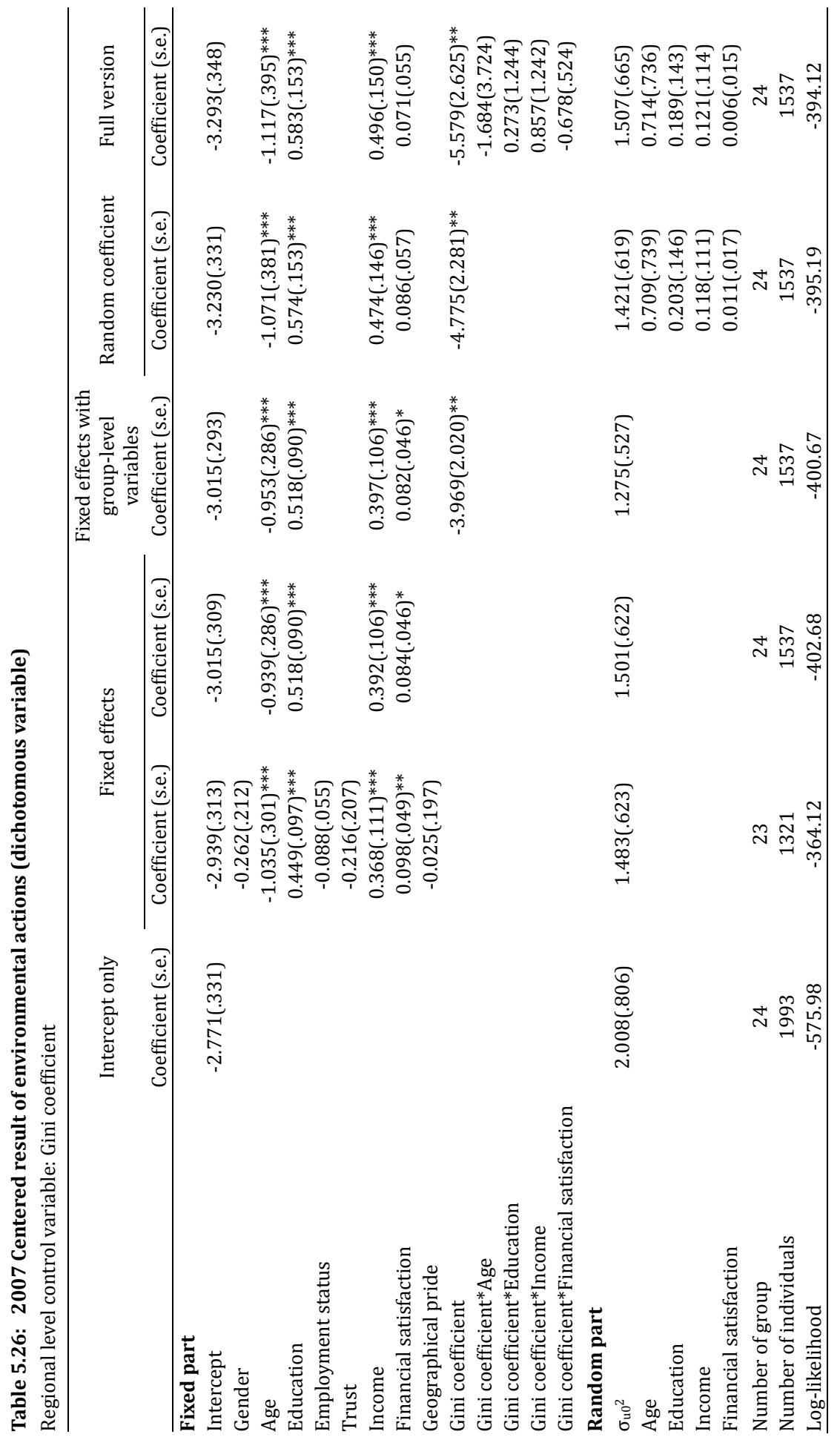


At the group level, the GDP per capita is not statistically correlated with environmental action in 1990 and 1995. The GDP per capita is negatively correlated with environmental action and statistically significant at the 5\% level in 2001. In 2007, the coefficient of GDP per capita is statistically significant at the $10 \%$ level in the full multilevel regression model. Urbanization is negatively correlated with environmental action and is statistically significant at the 5\% level in 2001, which is consistent with the results for environmental value and environmental attitude. The Gini coefficient is characterized by a statistically significant negative relationship with environmental action in 2007, which implies that high inequality led to low levels of environmental action.

\subsubsection{Discussion of the Regional Level Variable GDP per capita and the Quadratic GDP per capita}

Based on the regression results, we find that the GDP per capita mainly has negative effects on the three environmental concern indicators in the four observational periods in China, which is inconsistent with the empirical results from developed countries where citizens with higher GDP per capita express great concern for the environment. As illustrated above, the GDP per capita and environmental concern may not have had a linear relationship. Based on the data for 35 countries from the World Values Survey for 1995-1997, Duroy (2008) suggested and proved the existence of a U-shaped relationship between the GDP per capita and measures of environmental action.

In our study, we generally observe negative correlations between the GDP per capita and environmental concern. Further exploration of the effects of the quadratic GDP per capita on the environmental concern indicators is warranted, and the U-shaped relationship between environmental concern and the GDP per capita is needed to be verified in China for our observational periods. Therefore, we add the quadratic GDP per capita term in the fixed-effect model with grouplevel variables and reanalyze the WVS Chinese data in 1990, 1995, 2001 and 2007. The results are presented in Table 5.27, Table 5.28 and Table 5.29.

From our results, we find evidence of a U-shaped relationship between the GDP per capita and environmental concern indicators, although not for all of the observational periods. In 2007, all three environmental concern indicators are negatively correlated with the GDP per capita and are positively correlated with the quadratic GDP per capita, and they are both statistically significant at the $1 \%$ level. This strongly supports the existence of a U-shaped relationship between environmental concern and GDP per capita. We do not find statistically significant correlations between environmental concern and GDP per capita for 2001. In 1995, the environmental value indicator shows a U-shaped relationship with GDP per capita; it is negatively correlated with GDP per capita, positively correlated with quadratic GDP per capita and is statistically significant at the 5\% level. For the remaining two environmental concern indicators, environmental attitude and environmental action, we do not find statistically significant correlations. For the 1990 WVS Chinese data, environmental value and environmental attitude do not have 
statistically significant correlations with GDP per capita or quadratic GDP per capita. Unexpectedly, environmental action is positively correlated with GDP per capita and negatively correlated with quadratic GDP per capita, and they are both statistically significant at the 1\% level. This result is not consistent with other empirical studies in the literature; however, it may provide additional information on the evolution of environmental concern in China.

Table 5.27: Centered result of environmental value with quadratic GDP per capita

\begin{tabular}{|c|c|c|c|c|}
\hline & $\begin{array}{c}1990 \\
\text { centering }\end{array}$ & $\begin{array}{c}1995 \\
\text { centering }\end{array}$ & $\begin{array}{c}2001 \\
\text { centering }\end{array}$ & $\begin{array}{c}2007 \\
\text { centering }\end{array}$ \\
\hline \multicolumn{5}{|l|}{ Fixed part } \\
\hline Intercept & $-2.662(.153)$ & $-1.538(.077)$ & $-3.308(.244)$ & $-2.626(.151)$ \\
\hline Threshold 2 & $-1.123(.103)$ & $0.531(.061)$ & $-0.416(.127)$ & $-0.256(.112)$ \\
\hline Threshold 3 & $0.262(.095)$ & - & - & - \\
\hline Gender & $0.270(.138)^{*}$ & $-0.185(.110)^{*}$ & & \\
\hline Age & & $-0.681(.158)^{* * *}$ & $-1.676(.332)^{* * *}$ & \\
\hline Education & $0.261(.066)^{* * *}$ & & & $0.104(.057)^{*}$ \\
\hline Income & & & & $0.121(.060)^{* *}$ \\
\hline Financial satisfaction & & & $0.068(.036)^{*}$ & \\
\hline Trust & $0.260(.138)^{*}$ & & & $0.251(.124)^{* *}$ \\
\hline Geographical pride & $-0.250(.106)^{* *}$ & & & $0.252(.119)^{* *}$ \\
\hline GDP per capita & $-4.023(7.260)$ & $-70.11(35.03)^{* *}$ & $0.299(6.677)$ & $-25.44(7.883)^{* * *}$ \\
\hline Quadratic GDP per capita & $0.266(.459)$ & $3.979(2.001)^{* *}$ & $0.002(.359)$ & $1.234(.386)^{* * *}$ \\
\hline \multicolumn{5}{|l|}{ Random part } \\
\hline$\sigma_{\mathrm{u} 0^{2}}$ & $0.035(.039)$ & $0.000(-)$ & $0.131(.107)$ & $0.165(.073)$ \\
\hline Number of group & 11 & 6 & 23 & 23 \\
\hline Number of individuals & 786 & 1196 & 524 & 1150 \\
\hline Log-likelihood & -942.47 & -1222.76 & -404.86 & -949.21 \\
\hline
\end{tabular}


Table 5.28: Centered result of environmental attitudes (Willingness to pay) with quadratic GDP per capita

\begin{tabular}{|c|c|c|c|c|}
\hline & $\begin{array}{c}1990 \\
\text { centering }\end{array}$ & $\begin{array}{c}1995 \\
\text { centering }\end{array}$ & $\begin{array}{c}2001 \\
\text { centering }\end{array}$ & $\begin{array}{c}2007 \\
\text { centering }\end{array}$ \\
\hline \multicolumn{5}{|l|}{ Fixed part } \\
\hline Intercept & $2.123(.008)$ & $1.706(.012)$ & $2.115(.008)$ & 2.117(.009) \\
\hline Age & & & $-0.056(.021)^{* * *}$ & \\
\hline Education & $0.017(.007)^{* *}$ & $0.011(.005)^{* *}$ & $0.028(.007)^{* * *}$ & $0.016(.005)^{* * *}$ \\
\hline Employment status & $-0.011(.005)^{* *}$ & & & \\
\hline Income & $-0.016(.013)$ & $0.017(.008)^{* *}$ & & $0.025(.006)^{* * *}$ \\
\hline Financial satisfaction & $0.013(.003)^{* * *}$ & $0.010(.003)^{* * *}$ & $0.010(.002)^{* * *}$ & \\
\hline Trust & $0.029(.015)^{*}$ & $0.029(.012)^{* *}$ & & $0.048(.011)^{* * *}$ \\
\hline Geographical pride & $-0.028(.012)^{* *}$ & $-0.049(.010)^{* * *}$ & & $0.024(.011)^{* *}$ \\
\hline GDP per capita & $-0.522(.684)$ & $-11.213(7.362)$ & $0.702(.460)$ & $-1.664(.624)^{* * *}$ \\
\hline Quadratic GDP per capita & $0.030(.008)$ & $0.637(.421)$ & $-0.039(.025)$ & $0.081(.031)^{* * *}$ \\
\hline \multicolumn{5}{|l|}{ Random part } \\
\hline$\sigma_{\mathrm{e}}$ & $0.210(.005)$ & $0.214(.004)$ & $0.171(.004)$ & $0.192(.004)$ \\
\hline$\sigma_{\mathrm{u} 0}$ & $0.012(.013)$ & $0.024(.010)$ & $0.026(.010)$ & $0.030(.009)$ \\
\hline Number of group & 11 & 6 & 23 & 23 \\
\hline Number of individuals & 820 & 1220 & 808 & 1173 \\
\hline Log-likelihood & 113.75 & 145.98 & 272.5 & 260.85 \\
\hline
\end{tabular}

Table 5.29: Centered result of environmental action with quadratic GDP per capita

\begin{tabular}{|c|c|c|c|c|}
\hline & $\begin{array}{c}1990 \\
\text { centering }\end{array}$ & $\begin{array}{c}1995 \\
\text { centering }\end{array}$ & $\begin{array}{c}2001 \\
\text { centering }\end{array}$ & $\begin{array}{c}2007 \\
\text { centering }\end{array}$ \\
\hline \multicolumn{5}{|l|}{ Fixed part } \\
\hline Intercept & $4.610(.380)$ & $1.652(.071)$ & $1.158(.166)$ & $-3.093(.273)$ \\
\hline Threshold 2 & $6.047(.522)$ & - & $4.946(.357)$ & - \\
\hline Gender & $-1.026(.515)^{* *}$ & & & \\
\hline Age & & & & $-0.927(.286)^{* * *}$ \\
\hline Education & & $0.171(.030)^{* * *}$ & $0.351(.084)^{* * *}$ & $0.521(.090)^{* * *}$ \\
\hline \multicolumn{5}{|l|}{ Employment status } \\
\hline Income & $1.138(.406)^{* * *}$ & & $0.280(.095)^{* * *}$ & $0.389(.106)^{* * *}$ \\
\hline Financial satisfaction & & $0.032(.015)^{* *}$ & & $0.087(.046)^{*}$ \\
\hline GDP per capita & $93.164(22.620)^{* * *}$ & $-31.40(43.54)$ & $9.835(9.377)$ & $-45.98(16.82)^{* * *}$ \\
\hline Quadratic GDP per capita & $-5.909(1.439)^{* * *}$ & $1.782(2.490)$ & $-0.561(.504)$ & $2.273(.824)^{* * *}$ \\
\hline \multicolumn{5}{|l|}{ Random part } \\
\hline$\sigma_{\mathrm{e}}$ & & $1.216(.025)$ & - & - \\
\hline$\sigma_{\mathrm{u} 0}$ & & $0.145(.062)$ & - & - \\
\hline$\sigma_{\mathrm{u} 0}{ }^{2}$ & $0.000(-)$ & - & $0.432(.178)$ & $0.953(.420)$ \\
\hline Number of group & 11 & 6 & 23 & 24 \\
\hline Number of individuals & 978 & 1199 & 931 & 1537 \\
\hline Log-likelihood & -109.12 & -1940.01 & -552.28 & -398.99 \\
\hline
\end{tabular}

According to our empirical results, we argue that environmental concern indicators and GDP per capita might have an N-shaped relationship instead of a U-shaped relationship. Based on our data, we could divide the $\mathrm{N}$-shaped relationship be- 
tween GDP per capita and environmental concern indicators into three developmental stages.

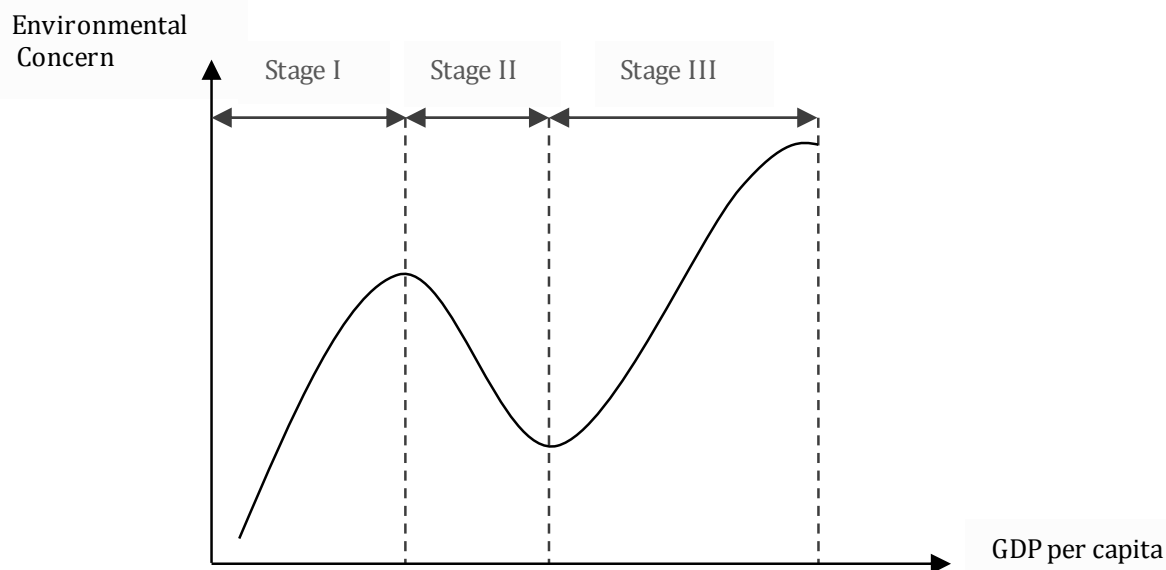

Figure 5.1: Relationship between environmental concern and the GDP per capita

At the initial stage of development (stage I) when a country is in a poor economic condition, economic development would lead to an increase of environmental concern because at this stage, citizens are still struggling with basic needs and do not have the time or resources to access environmental knowledge. However, there is also limited environmental knowledge and information available from media or other channels. Following the development and increase of GDP per capita, citizens' basic needs are gradually satisfied; therefore, they would have more time and resources to obtain environmental knowledge, and an increase of GDP per capita at this stage positively affects the environmental concern among citizens.

With further economic development, poor nations gradually shift to middle income countries, and the relationship between environmental concern and the GDP per capita enters stage II in Figure 5.1. As a result of economic development, the quality of life of citizens is further improved. Citizens benefit significantly from economic development. When they experience all of the benefits brought by economic development, a natural consequence is the desire to retain such benefits; therefore, citizens devote all of their resources to economic development. At this stage, the environment is not seriously damaged. Thus, when there is a conflict between economic development and environmental protection, the citizens tend to select economic growth rather than environmental protection. As a result, we observe a decrease of environmental concern following the rise of GDP per capita in this period.

When a country becomes a middle-to-high-level or high-level income country, the relationship between environmental concern and economic development could be described by stage III in Figure 5.1. At this stage, citizens are economically solvent, and all of their basic needs are fulfilled. As a result of their development and 
ignorance of environmental protection in the previous two stages, the environment has been damaged by industries. Citizens' lives might be negatively affected by environmental deterioration; therefore, they become more concerned for quality of life instead of economic benefits, and a high-quality environment becomes much more important at this stage. This is a common issue that many countries have experienced or are currently experiencing. The restoration of a healthy environment becomes more important than economic development, and the environmental concern of citizens in such nations begins to increase subsequent to the continuous growth of GDP per capita. In summary, the relationship between environmental concern and economic development changes over time and forms an N-shaped curve.

Unfortunately, we do not find an overall statistical significance for all of the environmental concern indicators over the entire observational period in this study. We only obtain evidence of an $\mathrm{N}$-shaped relationship between environmental concern and economic development. This is also understandable. First, our data are cross-sectional for four periods rather than strictly longitudinal panel data, and the interviewees in each survey are different, which reduces the significance of our analysis. Second, the small sample size and the data quality affect the results. From the sample size of each wave, we notice that the sample size of the WVS from 1990 to 2007 are gradually enlarged, which positively influence the quality of the surveys. In 2007, the dataset contains 2015 individuals, which is more than two times the sample size in 1990. Third, later surveys are of a higher quality because of technical improvements and increases in the relative knowledge. For these reasons, we believe that the later WVS data has improved quality than previous WVS data. Thus, we argue that the 2007 WVS data is the optimum available data from the observational periods. We find statistically significant U-shaped correlations between three environmental concern indicators and GDP per capita in 2007, which strongly supports our hypothesis that stage II and stage III form an Nshaped curve. It is understandable that stage II and stage III had formed an Nshaped environmental concern-GDP per capita curve by 2007 because after three decades of development, China has already entered the middle stage of development by 2007. The 1990 data shows a clear stage I relationship between environmental action and the GDP per capita, with environmental concern increasing with the rise of the GDP per capita in China. Based on the 1995 Chinese survey data, we find that environmental value and GDP per capita become negatively correlated, which corresponds to stage II of our proposed N-shaped curve. Unfortunately we do not find any statistically significant relationships between environmental concern and GDP per capita based on the 2001 data analysis, which might have been caused by the data quality and sampling issues.

Although we do not observe statistically significant results for every environmental concern indicator in the four waves, the evidence from 1990, 1995 and 2007 has offered a partial explanation for the existence of the N-shaped relationship between environmental concern and the GDP per capita. Previous studies might not have found this $\mathrm{N}$-shaped relationship between environmental concern and GDP per capita because of limited data accessibility and missing data for the earlier 
development stages. Most survey data collected in the field began in the 1980s, and at that time, almost all of the developed countries had already reached high levels of income; therefore, only U-shaped curves would have been observed. However, in the later waves of the WVS survey, increasing numbers of developing countries were included, although they still account for a small portion of the survey. Moreover, observing the chronological relationship between environmental concern and GDP per capita based on cross-sectional data is more difficult at the international level.

China experienced an unprecedented rapid economic growth over the past three decades, which has shifted China from an extremely poor country to a middleincome nation in a relatively short time. Therefore, data from China provides a great opportunity to closely investigate the evolution of individual environmental concern over time subsequent to economic development. We argue that the Nshaped relationship between environmental concern and economic development might also be observed for other nations if longitudinal data are available, which covers different development stages, from extremely poor to extremely rich.

Our finding here is consistent with our finding in Chapter 2, in which we find the existence of a cubic water Kuznets curve. In Chapter 2, we prove the existence of a cubic water Kuznets curve, which describes an N-shaped relationship between the water consumption per capita and the GDP per capita in urban areas. In Figure 5.2, we present both the cubic water Kuznets curve and the N-shaped curve of environmental concern and the GDP per capita.

Based on Figure 5.2, we are able to better understand the evolution of environmental concern and water consumption per capita following the continuous increase of the GDP per capita in the urban areas in China. In stage I when a nation is in an extremely poor economic condition, environmental concern of the citizens increases along with economic development. At this stage, water consumption per capita also increases following economic growth and improved quality of life. In stage II, when a nation's economy flourishes, citizens benefit significantly from economic development and do not seriously suffer from environmental deterioration. Therefore, they tend to place most of their effort into economic development, even if such economic development is preconditioned on environmental deterioration.

As a result, we observed a decrease of environmental concern and a continuous increase of water consumption per capita in this stage. With further development, the tension between economic development and environmental protection becomes higher. With high income, citizens are not satisfied only by good economic conditions; instead, they require a higher quality of life with a better environment. Therefore, environmental concern among citizens increases in stage III. Citizens also conduct additional environmental actions to protect the environment, such as saving water, even if it means relinquishing some economic benefits. Hence, we observe a declining trend of water consumption per capita in stage III. 


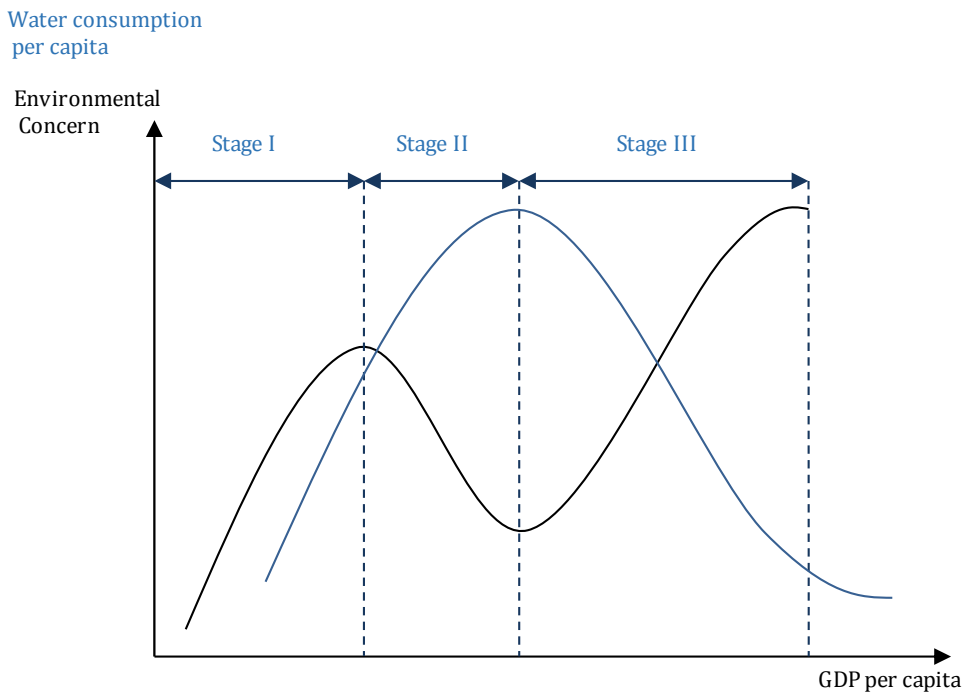

Figure 5.2: Cubic Water Kuznets Curve and environmental concern-GDP per capita relationship

\subsection{Conclusion and Policy Implications}

Intrinsic motivation is motivation that is activated within a person, whereas extrinsic motivation implies motivation inspired by fiscal incentives or social obligations (Berglund and Matti, 2006). An environmental application of the difference is when one performs environmentally friendly actions because of an environmental consciousness (if the costs are not too high) or because authorities have dictated such action or because such actions are financially beneficial. In traditional economics and contemporary environmental policymaking, the latter set of motives is primarily acknowledged as determining an individual's proenvironmental behavior. However, the former motivation is also important and could lead to positive environmental actions as well.

Environmental actions are affected by policy implementations (Frey, 1997; Brekke et al., 2003; Thøgersen, 2003), and for water consumption, individuals play dual roles, both as consumers and citizens. The conflict between the consumer and citizen roles is crystallized in this debate because purely economic incentives, such as price, sometimes fail to produce the desired goals. Therefore, parallel policies that focus on environmental value and environmental attitudes will assist in the establishment of environmentally friendly values and attitudes, which will further influence the environmental actions of individuals (Frey, 1999). Traditionally, economic incentives are the preferred regulatory instruments in environmental regulations. However, the characteristics of individuals have shown that the establishment of behavioral norms is a more promising route towards long-term and stable environmentally friendly performances. Because individuals might act 
according to the value of the activity rather than for benefit, an improved understanding of the individual's environmental values, environmental attitudes and environmental actions is crucial for policy makers. From this perspective, our work is meaningful for Chinese policy makers and potentially valuable for policy makers in other developing countries.

Based on the four waves of the World Value Survey of Chinese data, we examine the determinants of intrinsic motivation for an individual's environmental behaviorenvironmental concern with multilevel regression models at the individual level by controlling for the provincial-level factors in China. Contrary to previous studies that focused on the individual level only, we adopt multilevel regression models to investigate the environmental concern determinants both at the individual level and the provincial level.

Our empirical results show that environmental concern is affected by two groups of individual factors: socio-economic factors, such as individual economic status, education level, employment status, age and gender, and psychological factors, such as financial satisfaction, trust and geographical pride. Education, income, financial satisfaction and trust have positive effects on environmental concern over the observational period, whereas age is primarily negatively correlated with the environmental concern indicators.

It is clear that these results have policy value. The increasing education level of citizens will greatly contribute to increasing their environmental concern and improving their environmental behavior, especially for comparatively poor regions. Therefore, environmental policy makers should cooperate with educational authorities to increase the general education level of the entire population, especially in poor regions. From an economic perspective, increased income and financial satisfaction will lead to higher environmental concern among citizens. Young citizens show higher environmental concern, which implies that policy makers should focus on the aging population and should provide them with additional environmental information and knowledge to induce better environmental concern and actions.

At the group level (provincial level), the economic development status of an individual's location is important. The urbanization variable and the Gini coefficient variable are mainly negatively correlated with environmental concern indicators. The negative value of the urbanization coefficient indicates that urbanization during 1990-2007 in China led to a decrease of environmental concern in urban areas. Hence, as China is still experiencing extensive urbanization, environmental policy makers should make additional efforts to increase the environmental concern among new immigrants to urban areas. The negative correlation between the Gini coefficient and environmental concern indicators implies that reduced inequality leads to higher environmental concerns in society. Interestingly, GDP per capita has an $\mathrm{N}$-shaped relationship with environmental concern indicators in China. This N-shaped relationship shows that environmental concern will increase at earlier stages of development, decrease in the middle developmental stages, and then increase again following further economic growth. 
The decrease of environmental concern with increasing economic development might be a result of the tendency of citizens to select economic benefits rather than environmental protection when conflicts among those two objectives exist. Citizens who once suffered economically might be afraid of losing their economic benefits in the middle development stage; therefore, they give high scores to economic development rather than to environmental protection at that stage. When a nation moves forward and becomes more prosperous, citizens will achieve higher levels of income with relatively abundant material goods. At this point, environmental problems might become more visible and serious after massive industry development without proper pollution controls. As a result, citizens may have a higher requirement for a healthy environment. Therefore, environmental concerns of individuals will return to a high level. This finding is very useful for policy makers, especially those in developing countries. By recognizing the existence of an $\mathrm{N}$ shaped environmental concern curve, policy makers should focus on stage II of development, wherein environmental concern decreases following economic growth, to design and implement corresponding policies to increase the slope of the curve and to bring the turning point at the bottom forward; this can be accomplished by reducing the negative effects of economic development on environmental concerns, which would lead to better environmental performances among citizens.

By bridging environmental concern and water conservation behavior, our findings have also provided valuable information on the impact factors of water conservation behavior in China for the period 1990-2007. Our results show that education, income, and financial satisfaction had a positive correlation with water conservation behavior. The aging population tended to perform fewer water saving actions. Above all, economic development may lead to increased water saving behavior at the initial stage of development, which is mainly induced by economic motivations and rarely by environmental considerations. Following the economic development when citizens have become more prosperous, they may start to ignore water conservation because they do not have a great economic motivation for water saving; however, the environmental motivations were initially formed at this stage. Therefore, we observed a drop of water saving behavior among citizens. However, with further development, citizens pursue a higher quality of life in which the environment is one of the most important elements. With increased environmental concerns, citizens resume their environmentally friendly behavior, which is mainly stimulated by environmental motivations, such as water conservation behavior.

Our results are also meaningful for water-policy makers in China because we show that a citizen's water conservation behavior does not linearly increase but rather goes through a decreasing period. Policies specifically aim at stimulating environmental concerns in this decreasing period are crucial. Proper policy intervention could lead to better water consumption behavior in such periods and could reduce the negative impacts of economic development. Provinces suffering from water shortages could benefit more through proper policy intervention in the period when water conservation behaviors decrease. In Figure 5.2, we show that the bottom of the N-shaped environmental concern-GDP per capita curve corresponds 
to the peak of the cubic water Kuznets curve that was proposed in Chapter 2 . Therefore, our results in this chapter also reflect the fact that proper policy intervention at the individual level will stimulate water conservation behavior, which in turn will contribute to the reduction of the peak value of the cubic water Kuznets curve. As a result, we argue that it is important for water-policy makers to understanding the citizens' environmental concerns and water conservation behavior. By understanding their intrinsic motivation for environmentally friendly behavior, policy makers could better design and implement corresponding policies to improve the water consumption curve.

Our study contributes to the literature according to two aspects. First, it increases the empirical evidence of determinants of environmental concern in the context of a developing country (China). By linking environmental concern with water consumption behavior, our results also provide valuable information for the water authorities in China. Second, it fills the gap of multilevel regression analyses of environmental concern at the national level. Moreover, our findings provide useful information for environmental policy makers and water authorities on the intrinsic motivations of citizens when performing environmental behavior, which is supplemented by the extrinsic motivations generally examined in the economic literature. 
CHAPTER 6

Conclusion 


\subsection{Main Findings}

In this thesis, we address two important questions of urban water management: 1) what is the trajectory of urban water consumption and what are the determinants of its formation? and 2) what are the determinants of successful urban water management reform in developing countries and the roles of governments, businesses and individuals?

To answer the first question, we investigate the urban water consumption patterns of 27 countries during 1960-2010. We find that per capita urban water consumption has an N-shaped relationship with GDP per capita and is similar to the cubic form of the Environmental Kuznets Curve; hence, we name it the "Cubic Water Kuznets Curve" (CWKC). Three stages are identified on the CWKC curve according to the evolution of urban water consumption. At the initial stage of development, per capita urban water consumption increases following the increase of wealth and is mainly caused by the economic expansion and the transformation of the industrial composition of a country. Following economic development, the per capita urban water consumption peaks. Continuous economic growth leads to the decline of per capita urban water consumption and is identified as the second stage of the CWKC. At this stage, the technological improvement, the transformation of industrial compositions from secondary industry to tertiary industry and the increasing environmental concern among individuals contribute to the increase of water use efficiency and water conservation, which contributes to water consumption reduction. When the GDP per capita reaches an even higher level, as observed in some of the most developed countries, citizens become very rich and the societies enter the stage dominated by an ageing population. At this stage, per capita urban water consumption may increase slightly and then stabilise. This is mainly caused by the reduction of household sizes. When the number of people in a household declines, the per capita usage of standard water consumption, such as for cleaning and gardening, rises.

Following the literature of water consumption and the Environmental Kuznets Curve, we identify three groups of determinants: 1) the economic-related determinant that includes the economic scale factor, industrial composition factor and technical factor; 2) the policy determinant, which contains the efficiency water policy factor and effectiveness water policy factor; and 3) the endowments determinant, which is composed of climate factors and household factors. The dominant objective of our study is to investigate the policy effects of per capita urban water consumption. The results of our study show that the efficient policy factor is negatively correlated with per capita urban water consumption, statistically significant at the $1 \%$ level. This implies that the implementation of efficiency water policies will lead to a rapid increase in water efficiency and water use reduction. However, the effectiveness policy factor is positively correlated with per capita urban water consumption, while its quadratic term is negatively correlated with per capita urban water consumption; both are statistically significant. This result suggests that the long-term design and implementation of effectiveness water 
policy is required to achieve a reduction in the negative effects of the urban water system to the natural environment. Among the countries included in our study, China has the best performance. In China, the peak value of the per capita urban water consumption arrived at an early stage of development with 1042 US dollar GDP per capita, which is far lower than the turning point GDP per capita values in developed countries. This is mainly achieved through the urban water management reform and water policy implementation in China.

Therefore, a comprehensive study of urban water management reform with a focus of policy analysis is conducted in the remainder part of the thesis in which we attempt to answer our second research question. Based on the triangular interrelated relationship framework among the government, businesses and individuals, we examine the urban water management reform in China. The explorations of different actors' evolutions and performances in the reform provide valuable information on urban water management, especially in developing nations.

In China, urban water management reform is characterised by neo-liberalist policy adoption, which empowers the local government concerning financial, administrative and economic issues (decentralisation), emphasises market roles (marketisation), acknowledges individual economic activities (privatisation), and involves the public (public participation), with the aim of establishing integrated sustainable urban water management.

These characteristics are largely consistent with the water sector neo-liberalist reforms worldwide, both in the North and South. However, it is arguable that the different development stages and endowment conditions in developing countries require adjusted adoption of the North's neo-liberalist strategies on urban water management reform. Moreover, water privatisation in developing countries is accompanied by the participation of the foreign private sector from developed countries, further increasing the difficulty of urban water management in the developing world. If the developing countries directly adopt neo-liberalist strategies from the North without proper adjustment, then the reform will eventually fail to some degree. In fact, the prevalent public opposition and the massive withdrawal of the foreign private sector from water markets in many developing countries, mainly in Latin America, South Asia and Africa, reflects the management problems of the water reforms.

In China, the neo-liberalist reform of urban water management is accompanied by the restructure of water institutions, the establishment of a water legal system, the construction of a property rights system and a pricing system, and the formation of a water market. Those reforms strongly support the privatisation of the water sector and public participation in urban water management. Moreover, at the local level, the decentralisation policies empowered the local government and local water authorities to timely respond to any problems during the reform. At the national level, the state also adjusts water policies timely and effectively to correct the problems that emerge during the reform; these approaches contribute to the continuous growth of the water sector and greatly support the development of 
urban water management. The simultaneous adoption of supply-side management policies and demand-side management policies greatly contribute to the efficiency and success of the urban water management in China.

As the core policy in supply-side management, privatisation is adopted as the solution to the lack of funds, the lagging technologies, the backward management and the excess staff in the urban water sector beginning in the 1990s. After two decades of implementation, the privatisation lead to a vigorous urban water sector in China in which the foreign private sector is actively involved in water businesses, the state-owned water companies are successfully self-reformed and restructured, and the domestic private water sector is rapidly developed. Based on a Translog Stochastic Frontier Production Function and a Parametric Generalised Malmquist Productivity index, we investigate the productivity change of the Chinese urban water sector during 1999-2006. As a result, we find that the Chinese urban water sector achieved productivity growth in the study period, mainly through technical change. The foreign private water sector formed the frontier of the urban water sector in the observation period, and the domestic private sector also had very good performance, with an average technical efficiency score of approximately 0.98 , which was close to the frontier. State-owned water firms had the lowest technical efficiency scores, but their productivity was still improved over time. The slow improvement of state-owned water firms might be caused by the substantial accumulation of obsolete equipment, excess employees and historical backward management practices. The massive investments in the observation period cause a negative value of the scale efficiency change due to the diseconomies-of-scale characteristic of the water sector. In general, the technical efficiency change of Chinese urban water sector is positive in the observation period, which implies that the catching up effects do exist in the sector, but to a small extent. Thus, we argue that the productivity growth of Chinese urban water sector in the observation period is mainly achieved through technical change, which is the result of large-scale technological upgrades through technology embodied investment.

On the demand-side of management, water conservation is promoted through public participation policies. The synthesis of individual behaviour determines the outcome of an entire society. Individuals' behaviour is affected by fiscal incentives and social obligations; in the long-term, their behaviour is largely determined by their intrinsic motivations. Therefore, by examining individuals' environmental concern and water consumption behaviour evolution and related impact factors, our study provides a good evaluation of public participation policy implementation in the past and offers further information to future management.

In China, the government initiated the implementation of public participation policies in urban water management in the beginning of the 1990s with the aims of increasing citizens' water conservation awareness and water-saving behaviour. Deeply understanding citizens' intrinsic motivations could facilitate policy design and implementations, which further stimulate water conservation behaviour. Based on the four waves of the World Value Survey (WVS) data, we show that the public participation policies stimulate individuals' environmental concern and 
water conservation behaviour in China. We further examine the determinants of the intrinsic motivation for an individual's environmental concern and environmental behaviour with multilevel regression models at the individual level by controlling for the provincial-level factors in China. Two groups of individual factors are identified and investigated: socio-economic factors, such as individual economic status, education level, employment status, age and gender; and psychological factors, such as financial satisfaction, trust and geographical pride. By bridging environmental concern and water conservation behaviour, our findings have also provided valuable information on the impact factors of water conservation behaviour in China.

At the individual level, the education, income, financial satisfaction and trust variables have positive effects on the environmental concern indicators, while the age variable is primarily negatively correlated with the environmental concern indicators. At the group level (provincial level), the economic development status of an individual's location is important. The urbanisation variable and the Gini coefficient variable are mainly negatively correlated with the environmental concern indicators, but they are not statistically significant for every environmental concern indicator during the entire observation period. The negative value of the urbanisation coefficient indicates that urbanisation during 1990-2007 in China led to the decrease of environmental concern in urban areas, possibly caused by the massive number of immigrants from rural to urban areas. As China is still experiencing extensive urbanisation, this result suggests that environmental policy-makers should make additional efforts to increase the environmental concern among new immigrants to urban areas. The negative correlation between the Gini coefficient and environmental concern indicators implies that reduced inequality leads to higher environmental concerns in society. The GDP per capita has an $\mathrm{N}$-shaped relationship with the environmental concern indicators. This $\mathrm{N}$ shaped relationship shows that environmental concern increases at earlier stages of development, decreases in the middle developmental stages, and then increases again following further economic growth.

Regarding urban water conservation, this $\mathrm{N}$-shaped relationship implies that economic development leads to increased water-saving behaviour at the initial stage of development, which is mainly induced by economic motivation and rarely by environmental considerations. Following the economic development when citizens become more prosperous, citizens may start to ignore water conservation because they do not have a great economic motivation for saving water; thus, they score economic development higher than environmental protection. Hence, we observe a drop of water-saving behaviour among citizens in this stage. However, the environmental motivations are initially formed at this stage. With further development, citizens pursue a higher quality of life in which the environment is one of the most important elements. With increased environmental concern, citizens resume their environmentally friendly behaviour, which is mainly stimulated by environmental motivations, such as water conservation behaviour. 
As a result, we have been witnessing the successful transformation of urban water management and the boom of the urban water sector over the past three decades in China. Undoubtedly, China still has a long way to go to achieve sustainable urban water management. However, in general, the urban water management reform since 1979 has been successful. This largely relies on the government effort and capacity to restructure the water institution, construct a water legal system, establish a water market and property rights system, correct the water pricing system, regulate and supervise water companies and stimulate public participation.

The experience of urban water management in China suggests that 1) the neoliberalist strategy adoption in urban water management reform requires strong government that can provide effective guidance, regulation and supervision; 2) water is an economic good but also a public good, and the cooperation of the private sector and public sector is the best way to avoid public and private failures and achieve efficient and effective urban water management; and 3) the increasing water conservation awareness and water conservation behaviour among citizens requires government effort to involve the public in the decision-making processes, water education, and water information disclosures. However, all of these strategies require a capable, competent and flexible government in developing countries.

Our study of the Cubic Water Kuznets Curve broadens the literature of the Environment Kuznets Curve by studying a natural resource, i.e., water, in urban areas. It is the first research that empirically tests the policy effects of per capita urban water consumption based on panel data. The study of urban water management reform in China provides a comprehensive analysis of the urban water reform from different perspectives: the restructure of water institutions, the construction of the water legal system and the implementation of water policies. Our empirical research on water sector productivity change is the first study based on firm-level data in the field and potentially contributes to the literature of neo-liberalism and the empirical literature on productivity in the water sector. The research on environmental concern and water consumption behaviour in this thesis increases the empirical evidence of determinants of environmental concern in the context of a developing country (China). Contrary to previous studies that focused on the individual level only, we adopt multilevel regression models to investigate the environmental concern determinants at both the individual level and the provincial level, filling the gap of multilevel regression analyses of environmental concern at the national level.

\subsection{Policy Implications and Recommendations}

In this thesis, we conduct an in-depth analysis on urban water consumption and provide a comprehensive investigation of the urban water management reforms in China. 
The empirical result of Chapter 2 suggests that the implementation of efficiency water policies and effectiveness water policies contributes to the urban water conservation and sustainable water management. The properly designed and implemented efficiency water policies will strictly lead to a reduction of per capita urban water consumption. In contrast, the effects of the effectiveness water policies become significant gradually; therefore, long-term effectiveness water policies should be made by the government. This finding has significant policy implications for developing countries, as many of them are still on the left side of the CWKC. The rapid economic growth, population expansion and acceleration of urbanisation lead to the rapidly increasing urban water demand and serious water resource deterioration, which greatly challenge urban water management. According to our findings, if efficiency water policies and long-term effectiveness water policies are proper designed and implemented, the stress of the water demand in urban areas could be reduced by improving the Cubic Water Kuznets Curve, namely, by lowering the peak value of per capita urban water consumption and truncating the upward trend stage of the Cubic Water Kuznets Curve.

As one of the core strategies in the neo-liberalist reform of the water sector, privatisation has received much attention. However, the failure of privatisation reform in many developing countries, mainly in Latin America and Africa, caused serious debates on this issue. Some scholars and researcher believe that privatisation is not the solution to the water problems in the urban water sector of the developing world, namely, the lack of funds, excess staff, outdated technologies, lagging management skills, and backward water services. By examining firm-level data in the Chinese water sector, we prove that privatisation could contribute to the productivity increase in the sector when strong government monitor and intervention are present. It is worth noting that the privatisation in the Chinese urban water sector is accompanied by the restructuring of the water institutions, the development of water laws and regulations, the establishment of a property rights system and water pricing system, and the construction of a water market. All of these strategies are under the strong supervision and intervention of the Chinese government.

At the firm level, both domestic privately owned water firms and state-owned water firms benefit from the privatization reform. Technical change was the main contributor of the productivity achievement in the observation period (19992006). During the privatisation of the Chinese urban water sector, the government not only welcomed foreign investors but also strongly supported the restructuring of state-owned water firms and the growth of domestic privately owned ones. We witness the prosperity of the water sector in China in which state-owned, foreign owned and domestic privately owned water firms are all actively involved. Our results potentially explain the privatisation failures of the water sectors in some developing countries, such as Bolivia, Venezuela and Malaysia. In those countries, the governments completely left the water sector to the free markets without careful monitoring and proper intervention. As a result, the water services' quality significantly dropped and prices dramatically increased after the privatisation of the water sector, leading to massive demonstrations against it. Notably, the water 
sector privatisation in those countries was dominated by multinational corporations. Because domestic privately owned water firms did not obtain enough support and protection, they did not have the ability to compete directly with multinational corporations.

Our work provides a useful tool for water policy makers and water authorities to evaluate and regulate the sector (Aubert and Reynaud, 2005; Coelli and Walding, 2006; Erbetta and Cave, 2007; Saal et al., 2007). This methodology could also be used for evaluating individual policy effects in the water sector. Indeed, policy makers could use this method to gain insights into the comparative efficiencies of water firms during policy implementations. Potentially, our work could provide indicators to policy makers for designing relevant policies in the future.

At the individual level, the implementation of public participation policy influences the formation of environmental awareness and environmental actions. Unexpectedly, we do not find a continuously increasing environmental awareness among citizens but rather an-N shaped relationship between environmental concern and economic development. This might be the result of a dynamic competition between environmental concern and economic benefits. Three stages are identified. Initially, the rising wealth in a country leads to better education and knowledge dissemination. The implementation of economic incentives also stimulates environmental behaviour. Therefore, environmental concern and environmental behaviour are promoted. Individuals who used to suffer from poverty might score economic benefits highly when a conflict exists between environmental protection and economic development. Moreover, wealthier individuals are less sensitive to the economic incentives of environmental behaviour. Therefore, we observe a declining trend of environmental concern and environmental behaviour in the second stage. However, when a nation moves forward and its citizens become even more wealthy, environmental concern overtakes economic benefits. In such a case, citizens are more willing to carry out environmental actions. This finding is very useful to policy-makers, especially to those in the developing countries. By recognising the existence of an $\mathrm{N}$-shaped environmental concern curve, policy-makers should focus on the second stage of the environmental concern curve, namely, the interval of decline. Specific policies and more effort should be used for increasing the slope of the curve in this interval and making it positive as soon as possible. This largely relies on the efforts of the government regarding environmental education, information disclosure and public involvement in the decision-making process. The emphasis on environmental education and constructing an environmental information dissemination network are also important strategies for stimulating citizens' environmental concern and environmental actions, which lead to water conservation behaviour.

\subsection{Limitations and Areas for Future Research}

Our research attempts to provide first-hand information on the urban water consumption trajectory and Chinese urban water management reform. All of the 
developing countries in our dataset, although only a small sample, strongly support the existence of the CWKC and the policy effects on water conservation. Unfortunately, due to the data availability issue, we could not include more developing countries in the study of the CWKC in Chapter 2. By including more developing countries, further research could provide more information about urban water consumption patterns in developing countries.

Our examination of productivity changes in the urban water sector is based on firm-level data that covers the initial stage of privatisation, 1999-2006, and shows that privatisation contributed to the sector performance improvement. In general, the presence of the foreign water firms in the Chinese water market contributes to the sector prosperity. Unfortunately, we do not obtain the firm-level data of the Chinese water sector after 2006, limiting our study to the earlier stage of urban water sector privatisation. Water quality and service quality are crucial indicators of water sector performance and should be considered. Including those two variables would add quality elements to the productivity change evaluation and offer more precise results of the water sector achievement. Those limitations should be addressed by further research.

The environmental concerns and water consumption behaviour research in Chapter 5 is based on the WVS data. This survey series covers a long observation period and could provide longitudinal insight of environmental concern and water consumption behaviour changes over time. However, the inconsistency of the water-related questions in the surveys negatively affected our research as we could not directly investigate the evolution of water concerns and water consumption behaviour during the reform. We include Doshisha University's environmental survey data to further explore the effects of public participation policies in China; however, this survey is also limited by its scale and was carried out in only a few cities for short period. Though the approximation of the water price information based on the data of the capital cities in each province is reasonable, still it reduces the accuracy of our study. Currently, related research separately studies the intrinsic motivation and extrinsic motivation effects on environmental behaviours (economic incentives and environmental consciousness). A better understanding of the relationship between these two types of motivations and their effects over time could provide the government valuable information on policy design and implementation and should be addressed in future research.

In China, the urban water management reform is ongoing with the aim of achieving sustainable urban water management. The newly issued policies in the field as of the end of 2013 show that the government is trying to improve the wastewater and storm water management in the urban areas and develop an integrated sustainable urban water management system. Meanwhile, the government has also stimulated further pricing system reform with the idea of fully implementing an increased block price system in all cities by 2015 . To further stimulate the sector improvement and better regulate the sector, the government has launched a trial project of a benchmarking system in the water sector. Further research should follow-up on these projects. 



\section{Bibliography}

Adeloye, A., Nawaz, N., \& Montaseri, M. (1999). Climate change water resources planning impacts incorporating reservoir surface net evaporation fluxes: A case study. International Journal of Water Resources Development, 15, 561-581.

Aigner, D., Lovell, C. A., amp, \& Schmidt, P. (1977). Formulation and estimation of stochastic frontier production function models. Journal of Econometrics, 6, 21-37.

Ajzen, I., \& Fishbein, M. (1980). Understanding attitudes and predicting social behaviour.

Alcamo, J., Flörke, M., \& Märker, M. (2007). Future long-term changes in global water resources driven by socio-economic and climatic changes. Hydrological Sciences Journal, 52, 247-275.

Alchian, A. A. (1965). Some economics of property rights. Economic forces at work, 294-307.

Alvarez, A., Amsler, C., Orea, L., \& Schmidt, P. (2006). Interpreting and testing the scaling property in models where inefficiency depends on firm characteristics. Journal of Productivity Analysis, 25, 201-212.

Anderson, C., Lee, D., Pryce, G., \& Taal, M. (2010). Factors affecting environmental attitudes and volunteering in England and Wales. Working Paper.

Andreoni, J., \& Levinson, A. (2001). The simple analytics of the environmental Kuznets curve. Journal of Public Economics, 80, 269-286.

Antle, J. M., \& Heidebrink, G. (1995). Environment and Development: Theory and International Evidence. Economic Development and Cultural Change, 43, 603-625.

Anwandter, L., \& Ozuna, T. (2002). Can public sector reforms improve the efficiency of public water utilities? Environment and Development Economics, 7, 687-700.

Arrow, K., Bolin, B., Costanza, R., Dasgupta, P., Folke, C., Holling, C. S., Jansson, B.-O., Levin, S., Mäler, K.-G., Perrings, C., \& Pimentel, D. (1995). Economic growth, carrying capacity, and the environment. Ecological Economics, 15, 91-95.

Asher, C. C., Mahoney, J. M., \& Mahoney, J. T. (2005). Towards a property rights foundation for a stakeholder theory of the firm. Journal of Management \& Governance, 9, 5-32.

Aubert, C., \& Reynaud, A. (2005). The impact of regulation on cost efficiency: an empirical analysis of Wisconsin water utilities. Journal of Productivity Analysis, 23, 383-409.

Baldwin, R. (1995). Does sustainability require growth? Cambridge University Press.

Bank, W. (1992). World Development Report 1992: Development and Envrionment. In. Oxford: Oxford University Press.

Barbier, E. B. (1997). Introduction to the environmental Kuznets curve special issue. Environment and Development Economics, 2, 369-381.

Barbiroli, G. (2006). Eco-efficiency or/and eco-effectiveness? Shifting to innovative paradigms for resource productivity. The International Journal of Sustainable Development and World Ecology, 13, 391-395.

Battese, G. E., \& Coelli, T. J. (1995). A model for technical inefficiency effects in a stochastic frontier production function for panel data. Empirical economics, 20, 325-332.

Berger, M., \& Finkbeiner, M. (2010). Water footprinting: How to address water use in life cycle assessment? Sustainability, 2, 919-944.

Berglund, C., \& Matti, S. (2006). Citizen and consumer: the dual role of individuals in environmental policy. Environmental politics, 15, 550-571.

Bhattacharyya, A., Harris, T. R., Narayanan, R., \& Raffiee, K. (1995). Specification and estimation of the effect of ownership on the economic efficiency of the water utilities. Regional science and urban Economics, 25, 759-784.

Bhattacharyya, A., Parker, E., \& Raffiee, K. (1994). An examination of the effect of ownership on the relative efficiency of public and private water utilities. Land Economics, 197-209.

Birrell, B., Rapson, V., \& Smith, T. F. (2005). Impact of Demographic Change and Urban Consolidation of Domestic Water Use: Water Services Association of Australia Melbourne.

Bo, S. (2011). A literature survey on environmental Kuznets curve. Energy Procedia, 5, 1322-1325. 
Bottasso, A., \& Conti, M. (2003). Cost inefficiency in the English and Welsh water industry: an heteroskedastic stochastic cost frontier approach: University of Essex.

Braungart, M., McDonough, W., \& Bollinger, A. (2007). Cradle-to-cradle design: creating healthy emissions - a strategy for eco-effective product and system design. Journal of Cleaner Production, 15, 1337-1348.

Brechin, S. R., \& Kempton, W. (1994). Global environmentalism: A challenge to the postmaterialism thesis? Social Science Quarterly, 75, 245-269.

Brekke, K. A., Kverndokk, S., \& Nyborg, K. (2003). An economic model of moral motivation. Journal of Public Economics, 87, 1967-1983.

Browder, G., \& Xie, S. (2007). Stepping up: improving the performance of China's urban water utilities: World Bank Publications.

Bruggink, T. H. (1982). PUBLIC VERSUS REGULATED PRIVATE ENTERPRISE IN THE MUNICIPAL WATER INDUSTRY-A COMPARISON OF OPERATING COSTS. Quarterly Review of Economics and Business, 22, 111-125.

Cai, X., \& Rosegrant, M. W. (2002). Global water demand and supply projections: Part 1. A modeling approach. Water International, 27, 159-169.

Cameron, L. D. (2002). Promoting positive environmental behaviours through community interventions: A case study of waste minimisation. In Environment Waikoto Technical Report No. 13: Hamilton: Waikato Regional Council.

Carr, J. E., Chase, E. B., Paulson, R. W., \& Moondy, D. W. (1990). National water summary 1987. In.

Caves, D. W., Christensen, L. R., \& Diewert, W. E. (1982). The economic theory of index numbers and the measurement of input, output, and productivity. Econometrica: Journal of the Econometric Society, 1393-1414.

Chambers, R. G. (1988). Applied production analysis: a dual approach: Cambridge University Press.

Chavas, J. P. (2004). On impatience, economic growth and the environmental Kuznets curve: A dynamic analysis of resource management. Environmental \& Resource Economics, 28, 123152.

Chen, Y., Zhang, D., Sun, Y., Liu, X., Wang, N., \& Savenije, H. H. (2005). Water demand management: a case study of the Heihe River Basin in China. Physics and Chemistry of the Earth, Parts A/B/C, 30, 408-419.

Clark, W. A., \& Finley, J. C. (2007). Determinants of water conservation intention in Blagoevgrad, Bulgaria. Society and natural resources, 20, 613-627.

Coelli, T. (2003). A primer on efficiency measurement for utilities and transport regulators (Vol. 953): World Bank Publications.

Coelli, T., \& Walding, S. (2006). Performance measurement in the Australian water supply industry: A preliminary analysis. Performance measurement and regulation of network utilities, 29-62.

Coelli, T. J., Rao, D. S. P., O'Donnell, C. J., \& Battese, G. E. (2005). An introduction to efficiency and productivity analysis: Springer.

Cole, M. A. (2004). Economic growth and water use. Applied Economics Letters, 11, 1-4.

COLE, M. A., RAYNER, A. J., \& BATES, J. M. (1997). The environmental Kuznets curve: an empirical analysis. Environment and Development Economics, 2, 401-416.

Cole, R. J. (2012). Transitioning from green to regenerative design. Building Research \& Information, 40, 39-53.

Coombes, P. J., \& Kuczera, G. (2002). Integrated urban water cycle management: Moving towards systems understanding. In Proceedings of the 2nd National Conference on Water Sensitive Urban Design, Engineers Australia (pp. 2-4).

Corbella, H. M., \& i Pujol, D. S. (2009). What lies behind domestic water use?: a review essay on the drivers of domestic water consumption. Boletín de la Asociación de Geógrafos Españoles, 297314.

Corraliza, J. A., \& Berenguer, J. (2000). Environmental Values, Beliefs, and Actions A Situational Approach. Environment and Behavior, 32, 832-848.

Corral-Verdugo, V. c., Bechtel, R. B., \& Fraijo-Sing, B. (2003). Environmental beliefs and water conservation: An empirical study. Journal of Environmental Psychology, 23, 247-257. 
Cosier, M., \& Shen, D. (2009). Urban water management in China. Water Resources Development, 25, 249-268.

Crain, W. M., \& Zardkoohi, A. (1978). Test of the Property-Rights Theory of the Firm: Water Utilities in the United States, A. JL \& Econ., 21, 395.

Cropper, M., \& Griffiths, C. (1994). The Interaction of Population Growth and Environmental Quality. The American Economic Review, 84, 250-254.

Culas, R. J. (2007). Deforestation and the environmental Kuznets curve: An institutional perspective. Ecological Economics, 61, 429-437.

Da Silva e Souza, G., De Faria, R. C., \& Moreira, T. B. S. (2007). Estimating the Relative Efficiency of Brazilian Publicly and Privately Owned Water Utilities: A Stochastic Cost Frontier Approach1. JAWRA Journal of the American Water Resources Association, 43, 1237-1244.

Dasgupta, S., Laplante, B., Wang, H., \& Wheeler, D. (2002). Confronting the environmental Kuznets curve. Journal of Economic Perspectives, 16, 147-168.

De Alessi, L. (1983). Property rights, transaction costs, and X-efficiency: an essay in economic theory. American Economic Review, 73, 64-81.

De Brunyn, S. M. (1997). Explaining the environmental Kuznets curve: structural change and international agreements in reducing sulphur emissions. Environment and Development Economics, 2, 485-503.

Demsetz, H. (1967). Toward a theory of property rights. Law and Economics, 1, 341-353.

Diekmann, A., \& Franzen, A. (1999). The wealth of nations and environmental concern. Environment and Behavior, 31, 540-549.

Dietz, T., Stern, P. C., \& Guagnano, G. A. (1998). Social structural and social psychological bases of environmental concern. Environment and Behavior, 30, 450-471.

Dinda, S. (2004). Environmental Kuznets Curve Hypothesis: A Survey. Ecological Economics, 49, 431-455.

Duarte, R., Pinilla, V., \& Serrano, A. (2013). Is there an environmental Kuznets curve for water use? A panel smooth transition regression approach. Economic Modelling, 31, 518-527.

Dunlap, R. E., \& Mertig, A. G. (1995). Global concern for the environment: is affluence a prerequisite? Journal of Social Issues, 51, 121-137.

Duroy, Q. M. (2005). The determinants of environmental awareness and behavior. Documento de trabajo del Departmento de Economía, Denison University, Estados Unidos.

Duroy, Q. M. (2008). Testing the affluence hypothesis: A cross-cultural analysis of the determinants of environmental action. The Social Science Journal, 45, 419-439.

Ehrhardt-Martinez, K., Crenshaw, E. M., \& Jenkins, J. C. (2002). Deforestation and the Environmental Kuznets Curve: A Cross-National Investigation of Intervening Mechanisms. Social Science Quarterly, 83, 226-243.

Eisenberg, D., \& Reed, W. (2003). Regenerative design: Toward the re-integration of human systems within nature. In Article from the Pittsburgh Papers, Selected Presentations from the Greenbuild Conference (2003).[Online] URL: http://www. integrativedesign. net/files/u1/regenerative_reintegration. pdf Accessed (Vol. 31, pp. 2007).

Engel, U., \& Pötschke, M. (1998). Willingness to pay for the environment: social structure, value orientations and environmental behaviour in a multilevel perspective. Innovation: The European Journal of Social Science Research, 11, 315-332.

Erbetta, F., \& Cave, M. (2007). Regulation and efficiency incentives: Evidence from the England and Wales water and sewerage industry. Review of Network Economics, 6.

Estache, A., \& Kouassi, E. (2002). Sector organization, governance, and the inefficiency of African water utilities (Vol. 2890): Governance, Regulation, and Finance Division, World Bank Institute.

Estache, A., \& Rossi, M. A. (2002). How different is the efficiency of public and private water companies in Asia? The World Bank Economic Review, 16, 139-148.

Estache, A., \& Trujillo, L. (2003). Efficiency effects of" privatization" in Argentina's water and sanitation services. Water Policy, 5, 369-380.

Fairbrother, M. (2013). Rich people, poor people, and environmental concern: Evidence across nations and time. European sociological review, 29, 910-922. 
Feigenbaum, S., \& Teeples, R. (1983). Public versus private water delivery: a hedonic cost approach. The Review of Economics and Statistics, 672-678.

Filippini, M., Hrovatin, N., \& Zorić, J. (2008). Cost efficiency of Slovenian water distribution utilities: an application of stochastic frontier methods. Journal of Productivity Analysis, 29, 169-182.

Fransson, N., \& Gärling, T. (1999). Environmental concern: Conceptual definitions, measurement methods, and research findings. Journal of Environmental Psychology, 19, 369-382.

Franzen, A. (2003). Environmental attitudes in international comparison: An analysis of the ISSP surveys 1993 and 2000*. Social Science Quarterly, 84, 297-308.

Fraquelli, G., \& Moiso, V. (2005). Cost efficiency and economies of scale in the Italian water industry. In XVII Conferenza società italiana di economia pubblica. Finanziamento del settore pubblico.

Freire, F., Thore, S., \& Ferrao, P. (2001). Life cycle activity analysis: logistics and environmental policies for bottled water in Portugal. OR-Spektrum, 23, 159-182.

Frey, B. S. (1997). Not just for the money: An economic theory of personal motivation: Edward Elgar Publishing.

Frey, B. S. (1999). Morality and rationality in environmental policy. Journal of Consumer Policy, 22, 395-417.

Fugui, L., Bing, X., \& Bing, X. (2008). Improving public access to environmental information in China. Journal of Environmental Management, 88, 1649-1656.

Fujita, K., \& Hill, R. C. (2007). The zero waste city: Tokyo's quest for a sustainable environment. Journal of Comparative Policy Analysis, 9, 405-425.

García-Sánchez, I. M. (2006). Efficiency measurement in Spanish local government: the case of municipal water services. Review of Policy Research, 23, 355-372.

Gassner, K., Popov, A. A., \& Pushak, N. (2009). Does Private Sector Participation Improve Performance in Electricity and Water Distribution? (Vol. 6): World Bank Publications.

Gato, S., Jayasuriya, N., \& Roberts, P. (2007). Forecasting residential water demand: Case study. Journal of Water Resources Planning and Management-Asce, 133, 309-319.

Gilg, A., \& Barr, S. (2006). Behavioural attitudes towards water saving? Evidence from a study of environmental actions. Ecological Economics, 57, 400-414.

Givens, J. E., \& Jorgenson, A. K. (2011). The effects of affluence, economic development, and environmental degradation on environmental concern: a multilevel analysis. Organization \& Environment, 24, 74-91.

Gleick, P. H. (2003). Water use. Annual Review of Environment and Resources, 28, 275-314.

Greene, W. (2005a). Fixed and random effects in stochastic frontier models. Journal of Productivity Analysis, 23, 7-32.

Greene, W. (2005b). Reconsidering heterogeneity in panel data estimators of the stochastic frontier model. Journal of Econometrics, 126, 269-303.

Grossman, G. M., \& Krueger, A. B. (1991). Environmental impacts of a North American free trade agreement. NBER Working Paper No. w3914.

Grossman, G. M., \& Krueger, A. B. (1995). Economic-growth and the environment. Quarterly Journal of Economics, 110, 353-377.

Harbaugh, W. T., Levinson, A., \& Wilson, D. M. (2002). Reexamining the empirical evidence for an environmental Kuznets curve. Review of Economics and Statistics, 84, 541-551.

Harremoës, P. (1997). Integrated water and waste management. Water Science and Technology, $35,11-20$.

Hassell, T., \& Cary, J. (2007). Promoting behavioural change in household water consumption: literature review. Victoria, Smart Water.

Hayes, B. C. (2001). Gender, scientific knowledge, and attitudes toward the environment: A crossnational analysis. Political Research Quarterly, 54, 657-671.

Heerink, N., Mulatu, A., \& Bulte, E. (2001). Income inequality and the environment: aggregation bias in environmental Kuznets curves. Ecological Economics, 38, 359-367.

Hellström, D., Jeppsson, U., \& Kärrman, E. (2000). A framework for systems analysis of sustainable urban water management. Environmental Impact Assessment Review, 20, 311-321. 
Hettige, H., Huq, M., Pargal, S., \& Wheeler, D. (1996). Determinants of pollution abatement in developing countries: Evidence from South and Southeast Asia. World Development, 24, 1891-1904.

Hettige, H., Mani, M., \& Wheeler, D. (2000). Industrial pollution in economic development: the environmental Kuznets curve revisited. Journal of Development Economics, 62, 445-476.

Hettige, H., Martin, P., Singh, M., Wheeler, D., \& Mundial, B. (1995). The industrial pollution projection system: World Bank.

Hirsh, J. B. (2010). Personality and environmental concern. Journal of Environmental Psychology, $30,245-248$.

Hoehn, J., \& Adanu, K. (2008). Do growth, investment, and trade encourage water use or water conservation? Letters in Spatial and Resource Sciences, 1, 127-146.

Homer, P. M., \& Kahle, L. R. (1988). A structural equation test of the value-attitude-behavior hierarchy. Journal of personality and social psychology, 54, 638.

Horvath, R. J. (1994). NATIONAL-DEVELOPMENT PATHS 1965-1987 - MEASURING A METAPHOR. Environment and Planning A, 26, 285-305.

Hox, J. J. (2010). Multilevel analysis: Techniques and applications 2nd ed.: Psychology Press.

$\mathrm{Hu}$, J.-L., Wang, S.-C., \& Yeh, F.-Y. (2006). Total-factor water efficiency of regions in China. Resources Policy, 31, 217-230.

Idelovitch, E., \& Ringskog, K. (1995). Private sector participation in water supply and sanitation in Latin America: World Bank Publications.

International Hydrological Programme(IHP) (2005). Information about World Water Use and Availability.

Inglehart, R. (1995). Public support for environmental protection: Objective problems and subjective values in 43 societies. PS: Political Science \& Politics, 28, 57-72.

Inglehart, R. (1997). Modernization, postmodernization and changing perceptions of risk. International Review of Sociology, 7, 449-459.

Japan), I.-J. I. D. I. (1997). Drought conciliation and water rights-Japanese experience. In. Ministry of Construction, Tokyo, Japan.

Jia, S. F., Yang, H., Zhang, S. F., Wang, L., \& Xia, J. (2006). Industrial water use Kuznets curve: Evidence from industrialized countries and implications for developing countries. Journal of Water Resources Planning and Management-Asce, 132, 183-191.

Jiang, W., \& Tang, Q. (2009). Water price reform in Beijing. Journal of Economics of Water Resources, Vol. 27 No. 3.

Jiang, Y. (2009). China's water scarcity. Journal of Environmental Management, 90, 3185-3196.

Jiang, Y., \& Zheng, X. (2010). Private Sector Participation and Performance of Urban Water Utilities in the People's Republic of China. In: Asian Development Bank.

Jorgensen, B. S., Martin, J. F., Pearce, M. W., \& Willis, E. M. (2013). Predicting Household Water Consumption With Individual-Level Variables. Environment and Behavior, 0013916513482462.

Jun, X. (2010). New Opportunity and Challenges on Integrated Water Supply and Water Demand Managements. Journal of Resources and Ecology, 1, 193-201.

Kellert, S. R. (1993). The biophilia hypothesis: Island Press.

Kim, S., \& Kim, S. (2010). COMPARATIVE STUDIES OF ENVIRONMENTAL ATTITUDE AND ITS DETERMINANTS IN THREE EAST ASIA COUNTRIES: KOREA, JAPAN, AND CHINA. International Review of Public Administration, 15, 17.

Kirkpatrick, C., Parker, D., \& Zhang, Y.-F. (2006). State versus private sector provision of water services in Africa: An empirical analysis. The World Bank Economic Review, 20, 143-163.

Koop, G., \& Tole, L. (1999). Is there an environmental Kuznets curve for deforestation? Journal of Development Economics, 58, 231-244.

Korfiatis, K. J., Hovardas, T., \& Pantis, J. D. (2004). Determinants of environmental behavior in societies in transition: evidence from five European countries. Population and Environment, 25, 563-584.

Lantz, V., \& Feng, Q. (2006). Assessing income, population, and technology impacts on CO2 emissions in Canada: Where's the EKC? Ecological Economics, 57, 229-238. 
Lee, S. (2010). Development of public private partnership (PPP) projects in the Chinese water sector. Water Resources Management, 24, 1925-1945.

Leeuw, B. (2005). The world behind the product. Journal of Industrial Ecology, 9, 7-10.

Li,F., Xiong, B. \& Xu, B. (2008). Improving public access to environmental information in China. Journal of Environmental Management, 88, 1649-1656.

List, J. A., \& Gallet, C. A. (1999). The environmental Kuznets curve: does one size fit all? Ecological Economics, 31, 409-423.

Lovell, C. K., Travers, P., Richardson, S., \& Wood, L. (1994). Resources and functionings: a new view of inequality in Australia: Springer.

Lundin, M. (1999). Assessment of the environmental sustainability of urban water systems: Technical Environmental Planning, Chalmers University of Technology.

Lynk, E. L. (1993). Privatisation, joint production and the comparative efficiencies of private and public ownership: the UK water industry case. Fiscal Studies, 14, 98-116.

Magnani, E. (2000). The Environmental Kuznets Curve, environmental protection policy and income distribution. Ecological Economics, 32, 431-443.

Magnani, E. (2001). The Environmental Kuznets Curve: development path or policy result? Environmental Modelling \& Software, 16, 157-165.

Managi, S. (2006). Pollution, natural resource and economic growth: an econometric analysis. International Journal of Global Environmental Issues, 6, 73-88.

Martinez-Alier, J. (1995). The environment as a luxury good or "too poor to be green"? Ecological Economics, 13, 1-10.

McDonough, W., \& Braungart, M. (2010). Cradle to cradle: Remaking the way we make things: Macmillan.

Meeusen, W., \& Van den Broeck, J. (1977). Technical efficiency and dimension of the firm: Some results on the use of frontier production functions. Empirical economics, 2, 109-122.

Milfont, T. L., Duckitt, J., \& Wagner, C. (2010). A Cross-Cultural Test of the Value-Attitude-Behavior Hierarchy. Journal of Applied Social Psychology, 40, 2791-2813.

Mitchell, V. G. (2006). Applying integrated urban water management concepts: A review of Australian experience. Environmental Management, 37, 589-605.

Morgan, W. D. (1977). INVESTOR OWNED VS. STATE-OWNED WATER AGENCIES: AN EVALUATION OF THE PROPERTY RIGHTS THEORY OF THE FIRM1. JAWRA Journal of the American Water Resources Association, 13, 775-781.

Mugisha, S. (2007). Effects of incentive applications on technical efficiencies: Empirical evidence from Ugandan water utilities. Utilities Policy, 15, 225-233.

Mulhall, D., \& Braungart, M. (2010). Cradle to cradle criteria for the built environment. EKONOMIAZ, 75, 182-193.

Ng, Y.-K., \& Wang, J. (1993). Relative income, aspiration, environmental quality, individual and political myopia: Why may the rat-race for material growth be welfare-reducing? Mathematical Social Sciences, 26, 3-23.

Orea, L. (2002). Parametric decomposition of a generalized Malmquist productivity index. Journal of Productivity Analysis, 18, 5-22.

Orecchini, F. (2007). A "measurable" definition of sustainable development based on closed cycles of resources and its application to energy systems. Sustainability Science, 2, 245-252.

Paldam, M. (2000). Social capital: one or many? Definition and measurement. Journal of economic surveys, 14, 629-653.

Panayotou, T. (1993). Empirical tests and policy analysis of environmental degradation at different stages of economic development. Working paper WP238, Technology and Employment Programme.

Panayotou, T. (1995). Environmental degradation at different stages of economi developlment. In I. Ahmed \& J. A. Doeleman (Eds.), Beyond Rio (The Environmental Crisis and Sustainable Livelihoods in the Third World). London: Macmillan: International Labor Organization.

Panayotou, T. (1997). Demystifying the environmental Kuznets curve: turning a black box into a policy tool. Environment and Development Economics, 2, 465-484. 
Peda, P., Grossi, G., \& Liik, M. (2013). Do ownership and size affect the performance of water utilities? Evidence from Estonian municipalities. Journal of Management \& Governance, 17, 237-259.

Perman, R., \& Stern, D. I. (2003). Evidence from panel unit root and cointegration tests that the environmental Kuznets curve does not exist. Australian Journal of Agricultural and Resource Economics, 47, 325-347.

Popp, D. (2005). Lessons from patents: using patents to measure technological change in environmental models. Ecological Economics, 54, 209-226.

Popp, D. (2010). Exploring links between innovation and diffusion: adoption of NOx control technologies at US coal-fired power plants. Environmental and Resource Economics, 45, 319352.

Rannikko, P. (1996). Local environmental conflicts and the change in environmental consciousness. Acta Sociologica, 39, 57-72.

Ray, S. C. (1999). Measuring scale efficiency from a translog production function. Journal of Productivity Analysis, 11, 183-194.

Renzetti, S., \& Dupont, D. P. (2009). Measuring the technical efficiency of municipal water suppliers: the role of environmental factors. Land Economics, 85, 627-636.

Robison, R., \& Hewison, K. (2005). Introduction: East Asia and the trials of neo-liberalism.

Roca, J. (2003). Do individual preferences explain the Environmental Kuznets curve? Ecological Economics, 45, 3-10.

Rock, M. T. (1998). Freshwater Use, Freshwater Scarcity, and Socioeconomic Development. The Journal of Environment \& Development, 7, 278-301.

Rock, M. T. (2000). The Dewatering of Economic Growth. Journal of Industrial Ecology, 4, 57-73.

Rosa, D., Vicente, P., \& Ana, S. (2011). Looking backward to look forward: water use and economic growth from a long-term perspective. Working paper AEHE-DT-1104.

Rosegrant, M. W., \& Cai, X. (2002). Global water demand and supply projections: part 2. Results and prospects to 2025. Water International, 27, 170-182.

Saal, D. S., \& Parker, D. (2000). The impact of privatization and regulation on the water and sewerage industry in England and Wales: a translog cost function model. Managerial and Decision Economics, 21, 253-268.

Saal, D. S., \& Parker, D. (2001). Productivity and price performance in the privatized water and sewerage companies of England and Wales. Journal of Regulatory Economics, 20, 61-90.

Saal, D. S., \& Parker, D. (2006). 11. Assessing the Performance of Water Operations in the English and Welsh Water Industry: A Lesson in the Implications of Inappropriately Assuming a Common Frontier. Performance measurement and regulation of network utilities, 297.

Saal, D. S., Parker, D., \& Weyman-Jones, T. (2007). Determining the contribution of technical change, efficiency change and scale change to productivity growth in the privatized English and Welsh water and sewerage industry: 1985-2000. Journal of Productivity Analysis, 28, 127-139.

Schaffrin, A. (2011). No Measure without Concept. A Critical Review on the Conceptualization and Measurement of Environmental Concern. International Review of Social Research, 11-31.

Selden, T. M., \& Song, D. (1994). Environmental Quality and Development: Is There a Kuznets Curve for Air Pollution Emissions? Journal of Environmental Economics and Management, 27, 147-162.

Shafik, N. (1994). ECONOMIC-DEVELOPMENT AND ENVIRONMENTAL-QUALITY - AN ECONOMETRIC-ANALYSIS. Oxford Economic Papers-New Series, 46, 757-773.

Shafik, N., \& Bandyopadhyay, S. (1992). Economic growth and envrionmental quality: time-series and cross-country evidence. In World Development Report Working Paper WPS 904: The World Bank, Washington, DC.

Shang, R. (1993). The government organization of P.R. China: 1949 1990: Economic Science Press.

Shen, D., \& Speed, R. (2009). Water resources allocation in the People's Republic of China. Water Resources Development, 25, 209-225.

Sheshinski, E., \& López-Calva, L. F. (2003). Privatization and its benefits: theory and evidence. CESifo Economic Studies, 49, 429-459. 
Solley, W. B., Pierce, R. R., \& Perlman, H. A. (1998). Estimated use of water in the United States in 1995. In USGS Numbered Series.

Starr, P. (1988). Meaning of Privatization, The. Yale L. \& Pol'y Rev., 6, 6.

Steel, B. S. (1996). Thinking globally and acting locally?: environmental attitudes, behaviour and activism. Journal of Environmental Management, 47, 27-36.

Stern, D. I. (2004). The Rise and Fall of the Environmental Kuznets Curve. World Development, 32, $1419-1439$.

Suri, V., \& Chapman, D. (1998). Economic growth, trade and energy: implications for the environmental Kuznets curve. Ecological Economics, 25, 195-208.

Takács-Sánta, A. (2007). Barriers to Environmental Concern. Human Ecology Review, 14.

Teeples, R., \& Glyer, D. (1987). Cost of water delivery systems: specification and ownership effects. The Review of Economics and Statistics, 399-408.

Thøgersen, J. (2003). Monetary incentives and recycling: Behavioural and psychological reactions to a performance-dependent garbage fee. Journal of Consumer Policy, 26, 197-228.

Thøgersen, J., \& Ölander, F. (2002). Human values and the emergence of a sustainable consumption pattern: A panel study. Journal of Economic Psychology, 23, 605-630.

Torgler, B., \& Garcia-Valiñas, M. A. (2005). The willingness to pay for preventing environmental damage. In: Center for Research in Economics, Management and the Arts (CREMA).

Torgler, B., \& Garcia-Valiñas, M. A. (2007). The determinants of individuals' attitudes towards preventing environmental damage. Ecological Economics, 63, 536-552.

Tropp, H. (2007). Water governance: trends and needs for new capacity development. Water Policy, 9, 19.

Tyler, T. R. (2000). Why do people cooperate in groups? Cooperation in modern society. Promoting the welfare of communities, states and organizations, 65-82.

UNESCO (2009). The United Nation World Water Development Report 3. The United Nations Educational, Scientific and Cultural Organization.

UNESCO (2012). The United Nations World Water Development Report 4. The United Nations Educational, Scientific and Cultural Organization.

Van Liere, K. D., \& Dunlap, R. E. (1980). The social bases of environmental concern: A review of hypotheses, explanations and empirical evidence. Public opinion quarterly, 44, 181-197.

Veisten, K., Fredrik Hoen, H., Navrud, S., \& Strand, J. (2004). Scope insensitivity in contingent valuation of complex environmental amenities. Journal of Environmental Management, 73, 317-331.

Vickers, J., \& Yarrow, G. (1991). Economic perspectives on privatization. The Journal of Economic Perspectives, 111-132.

Vincent, J. R. (1997). Testing for environmental Kuznets curves within a developing country. Environment and Development Economics, 2, 417-431.

Vorosmarty, C. J., Green, P., Salisbury, J., \& Lammers, R. B. (2000). Global water resources: Vulnerability from climate change and population growth. Science, 289, 284-288.

Wang, H., Wu, W., \& Zheng, S. (2011). An econometric analysis of private sector participation in China's urban water supply. Utilities Policy, 19, 134-141.

Wang, H.-J., \& Ho, C.-W. (2010). Estimating fixed-effect panel stochastic frontier models by model transformation. Journal of Econometrics, 157, 286-296.

Wang, H.-J., \& Schmidt, P. (2002). One-step and two-step estimation of the effects of exogenous variables on technical efficiency levels. Journal of Productivity Analysis, 18, 129-144.

Wesley Schultz, P. (2001). The structure of environmental concern: Concern for self, other people, and the biosphere. Journal of Environmental Psychology, 21, 327-339.

Wesley Schultz, P., \& Zelezny, L. (1999). Values as predictors of environmental attitudes: Evidence for consistency across 14 countries. Journal of Environmental Psychology, 19, 255-265.

Whittington, D. (1992). Possible adverse effects of increasing block water tariffs in developing countries. Economic Development and Cultural Change, 75-87.

Willis, R. M., Stewart, R. A., Panuwatwanich, K., Williams, P. R., \& Hollingsworth, A. L. (2011). Quantifying the influence of environmental and water conservation attitudes on household end use water consumption. Journal of Environmental Management, 92, 1996-2009.

Wilson, E. O. (1984). Biophilia: Harvard University Press. 
Witzke, H. P., \& Urfei, G. (2001). Willingness to pay for environmental protection in Germany: coping with the regional dimension. Regional Studies, 35, 207-214.

WMO. (1998). World Water Day (1997). In. http:/www.wmo.ch.

Woodbury, K., \& Dollery, B. (2004). Efficiency measurement in Australian local government: the case of New South Wales municipal water services. Review of Policy Research, 21, 615-636.

WORLD VALUES SURVEY 1990 OFFICIAL DATA FILE v.20090906. In. (1990): World Values Survey Association (www.worldvaluessurvey.org) Aggregate File Producer: ASEP/JDS, Madrid.

WORLD VALUES SURVEY 1995 OFFICIAL DATA FILE v.3. . In. (1995): World Values Survey Association (www.worldvaluessurvey.org) Aggregate File Producer: ASEP/JDS, Madrid.

WORLD VALUES SURVEY 2000 OFFICIAL DATA FILE v.20090914. In. (2000): World Values Survey Association (www.worldvaluessurvey.org) Aggregate File Producer: ASEP/JDS, Madrid.

WORLD VALUES SURVEY 2000 OFFICIAL DATA FILE v.20090901. In. (2009): World Values Survey Association (www.worldvaluessurvey.org). Aggregate File Producer: ASEP/JDS, Madrid.

Yandle, B., Bhattarai, M., \& Vijayaraghavan, M. (2004). Environmental Kuznets curves: a review of findings, methods, and policy implications. Research study, 2, 1-16.

Yandle, B., Vijayaraghavan, M., \& Bhattarai, M. (2002). The environmental Kuznets curve: a primer. PERC Research Study, 02-1. In.

Yoo, S. H. (2007). Urban water consumption and regional economic growth: The case of Taejeon, Korea. Water Resources Management, 21, 1353-1361.

Yu, A. L., \& Danqing, L. (2005). The Privatisation of Water Supply in China. In: Reclaiming Public Water. Transnational Institute.

Zhong, L., \& Mol, A. P. (2010). Water price reforms in China: policy-making and implementation. Water Resources Management, 24, 377-396.

Zhong, L., Mol, A. P., \& Fu, T. (2008). Public-private partnerships in China's urban water sector. Environmental Management, 41, 863-877. 



\section{Appendixes}




\section{Appendix A: \\ Table A: Determinants of Urban Water Consumption: Random-effects Model}

\begin{tabular}{|c|c|c|c|c|c|}
\hline \multirow{3}{*}{ Independent variables } & \multicolumn{5}{|c|}{ Dependent variable: Per capita urban water consumption } \\
\hline & $1960-2010$ & $1960-2010$ & $1960-2010$ & $1970-201$ & $01990-2010$ \\
\hline & (1) & $(2)$ & (3) & (4) & (5) \\
\hline GDP per capita & $\begin{array}{l}4.825^{* * *} \\
(0.825)\end{array}$ & $\begin{array}{l}0.753^{* * *} \\
(0.031)\end{array}$ & $\begin{array}{l}-0.019 \\
(0.124)\end{array}$ & $\begin{array}{l}0.826^{*} \\
(0.459)\end{array}$ & $\begin{array}{l}0.606^{* * *} \\
(0.222)\end{array}$ \\
\hline Quadratic GDP per capita & $\begin{array}{l}-0.618^{* * *} \\
(0.102)\end{array}$ & - & - & - & - \\
\hline Cubic GDP per capita & $\begin{array}{l}0.026^{* * *} \\
(0.004)\end{array}$ & - & - & - & - \\
\hline Fixed capital formation & - & $\begin{array}{l}0.104^{* * *} \\
(0.027)\end{array}$ & $\begin{array}{l}-0.013 \\
(0.136)\end{array}$ & $\begin{array}{l}-0.348 \\
(0.304)\end{array}$ & $\begin{array}{l}-0.205 \\
(0.198)\end{array}$ \\
\hline Secondary and tertiary industries & - & $\begin{array}{l}-1.755^{* * *} \\
(0.250)\end{array}$ & $\begin{array}{l}-2.541^{* *} \\
(1.029)\end{array}$ & $\begin{array}{l}-5.231 \\
(4.585)\end{array}$ & $\begin{array}{l}-10.56^{* * *} \\
(2.296)\end{array}$ \\
\hline Inward FDI & - & $\begin{array}{l}0.001 \\
(0.004)\end{array}$ & $\begin{array}{l}-0.021 \\
(0.022)\end{array}$ & $\begin{array}{l}-0.025 \\
(0.028)\end{array}$ & $\begin{array}{l}-0.017 \\
(0.028)\end{array}$ \\
\hline Triadic patents & - & $\begin{array}{l}0.022^{* * *} \\
(0.002)\end{array}$ & $\begin{array}{l}0.016 \\
(0.024)\end{array}$ & $\begin{array}{l}-0.091^{*} \\
(0.054)\end{array}$ & $\begin{array}{l}0.042 \\
(0.027)\end{array}$ \\
\hline Household size & - & $\begin{array}{l}-0.083^{* *} \\
(0.039)\end{array}$ & $\begin{array}{l}0.746^{* *} \\
(0.342)\end{array}$ & $\begin{array}{l}1.002^{* * *} \\
(0.357)\end{array}$ & $\begin{array}{l}0.981^{* * *} \\
(0.252)\end{array}$ \\
\hline Mean temperature & - & $\begin{array}{l}-0.031^{* *} \\
(0.014)\end{array}$ & $\begin{array}{l}0.008 \\
(0.057)\end{array}$ & $\begin{array}{l}0.229 * * \\
(0.107)\end{array}$ & $\begin{array}{l}0.149 \\
(0.109)\end{array}$ \\
\hline Total precipitation & - & $\begin{array}{l}0.055^{* * *} \\
(0.019)\end{array}$ & $\begin{array}{l}0.629 * * * \\
(0.134)\end{array}$ & $\begin{array}{l}0.721^{* * *} \\
(0.147)\end{array}$ & $\begin{array}{l}0.315^{* *} \\
(0.133)\end{array}$ \\
\hline Water productivity & - & $\begin{array}{l}-0.954^{* * *} \\
(0.016)\end{array}$ & - & - & - \\
\hline Wastewater treatment rate & - & - & $\begin{array}{l}0.515^{* * *} \\
(0.124)\end{array}$ & - & - \\
\hline Quadratic wastewater treatment rate & - & - & $\begin{array}{l}-0.030 \\
(0.023)\end{array}$ & - & - \\
\hline Sludge recycling rate & - & - & - & $\begin{array}{l}-0.369 \\
(0.746)\end{array}$ & - \\
\hline Quadratic sludge recycling rate & - & - & - & $\begin{array}{l}0.080 \\
(0.104)\end{array}$ & - \\
\hline $\begin{array}{l}\text { Public pollution control expenditure } \\
\text { on water and wastewater }\end{array}$ & - & - & - & - & $\begin{array}{l}-0.249 \\
(0.194)\end{array}$ \\
\hline $\begin{array}{l}\text { Quadratic public pollution control } \\
\text { expenditure on water and wastewater }\end{array}$ & - & - & - & - & $\begin{array}{l}0.030 \\
(0.026)\end{array}$ \\
\hline Constant & $\begin{array}{l}-6.69^{* * *} \\
(1.94)\end{array}$ & $\begin{array}{l}9.97^{* * *} \\
(1.03)\end{array}$ & $\begin{array}{l}11.11^{* * *} \\
(3.89)\end{array}$ & $\begin{array}{l}19.52 \\
(20.37)\end{array}$ & $\begin{array}{l}47.17^{* * *} \\
(9.81)\end{array}$ \\
\hline Year dummy & Included & Included & Included & Included & Included \\
\hline Number of observations & 513 & 213 & 151 & 87 & 128 \\
\hline Number of group & 27 & 20 & 13 & 12 & 18 \\
\hline
\end{tabular}

Note: The data between the parentheses are robust standard errors. *** denotes significance at the $1 \%$ level, ${ }^{* *}$ denotes significance at the $5 \%$ level, * denotes significance at the $10 \%$ level 


\section{Appendix B: \\ Per capita urban water consumption in 27 countries 1960-2010 (Not all countries' data cover the whole period)}

Per capita urban water consumption Australia

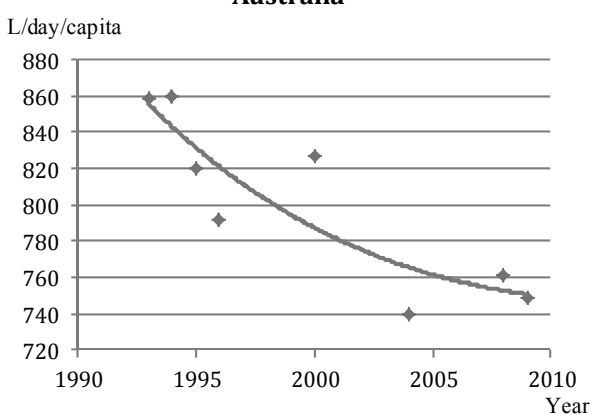

Per capita urban water consumption

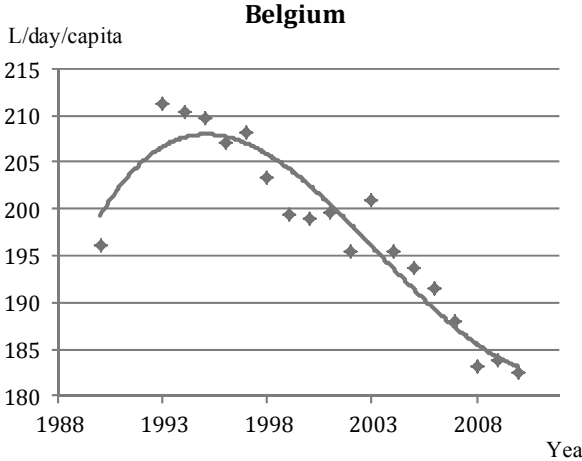

Per capita urban water consumption China

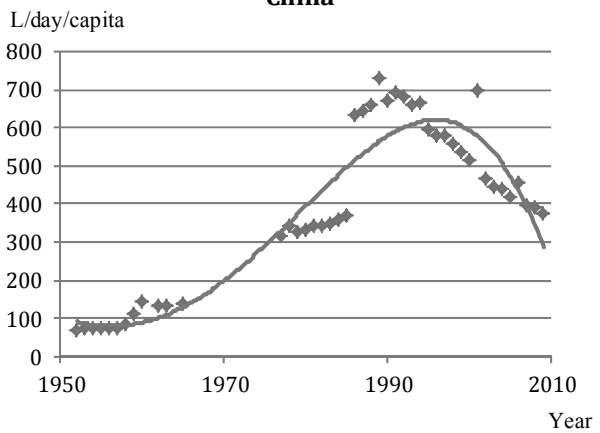

Per capita urban water consumption Austria

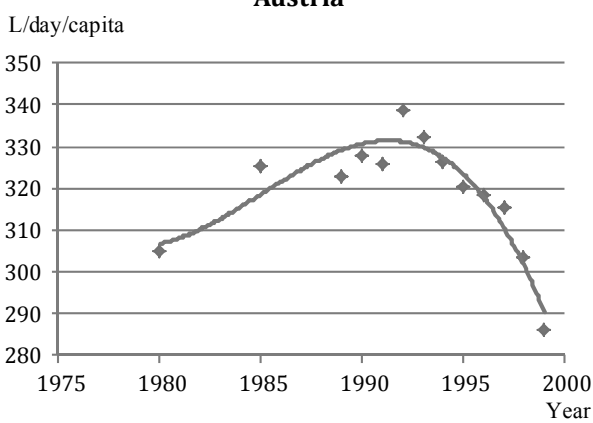

Per capita urban water consumption Canada

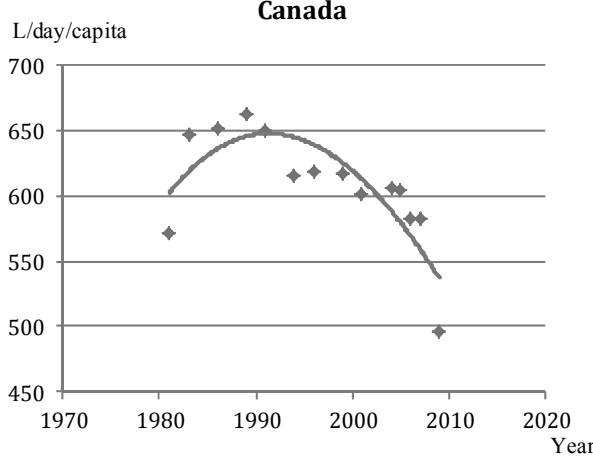

Per capita urban water consumption Denmark

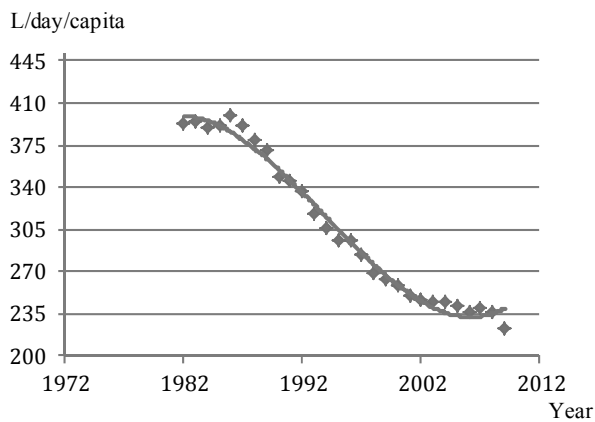




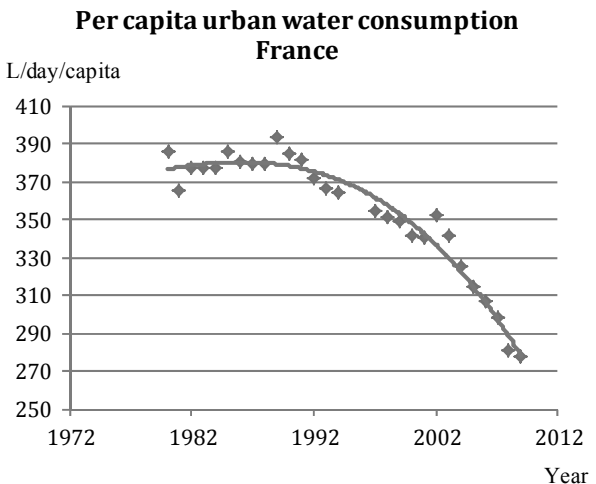

Per capita urban water consumption

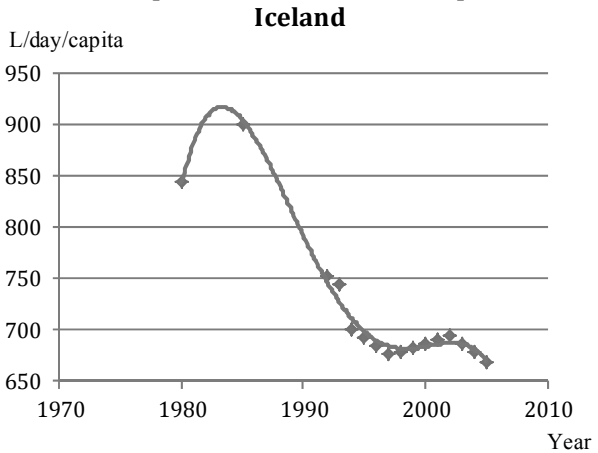

Per capita urban water consumption
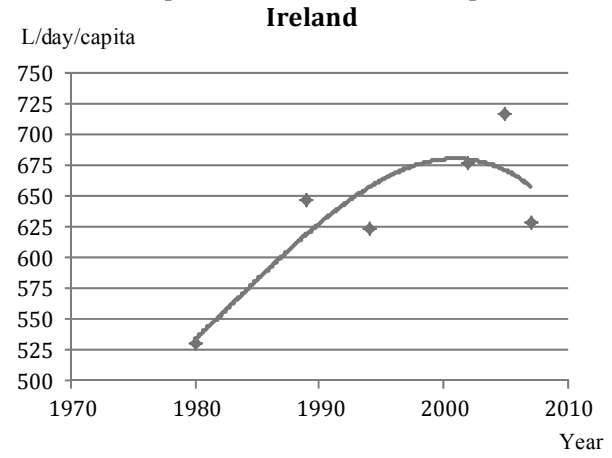

Per capita urban water consumption Germany

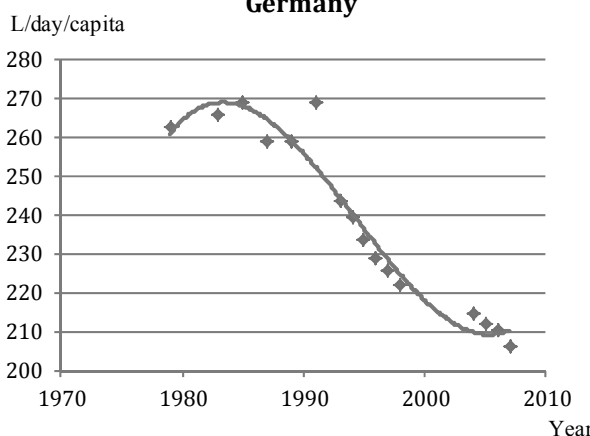

Per capita urban water consumption Greece

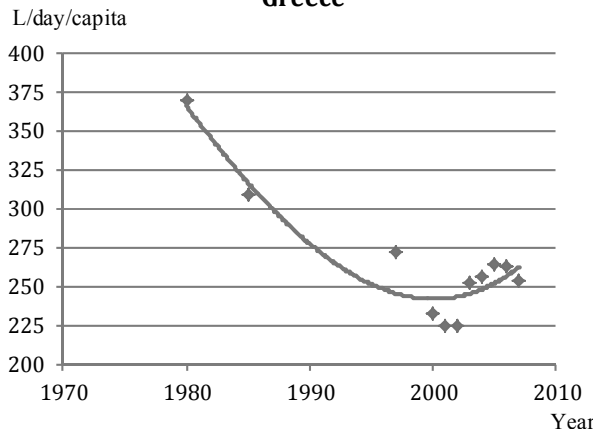

Per capita urban water consumption

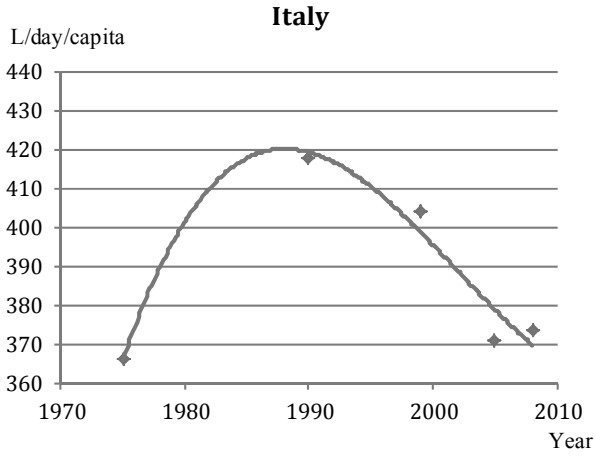




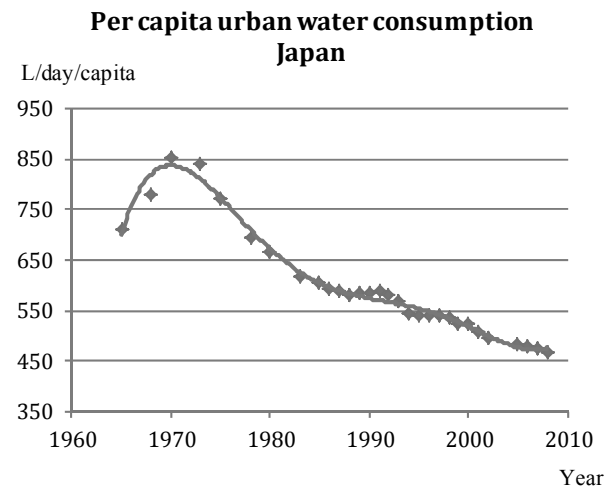

Per capita urban water consumption

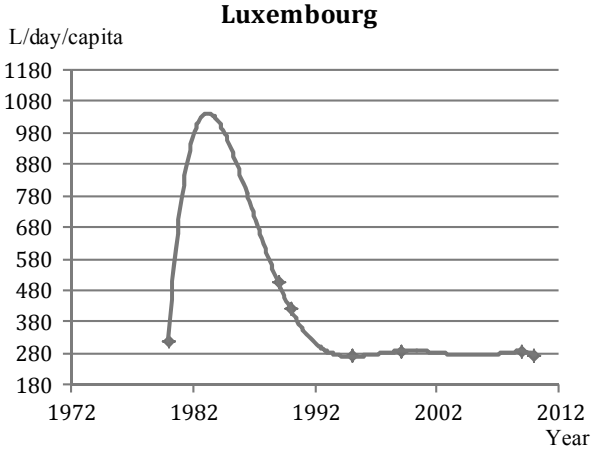

Per capita urban water consumption The Netherlands

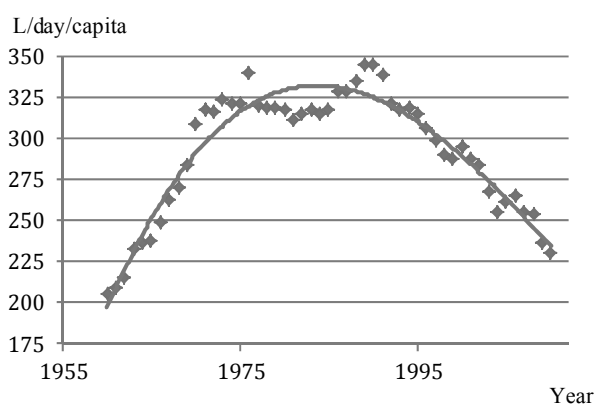

Per capita urban water consumption South Korea

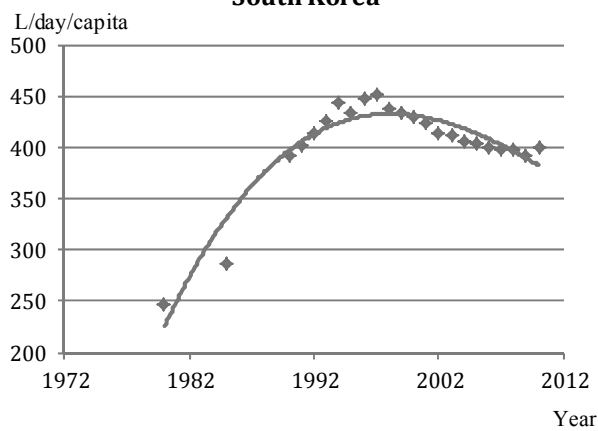

Per capita urban water consumption

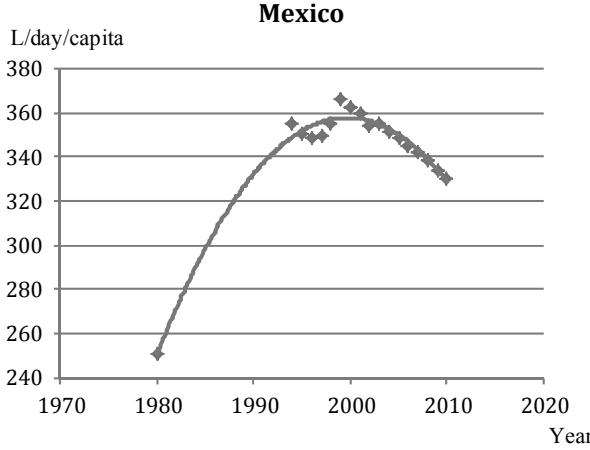

Per capita urban water consumption Norway

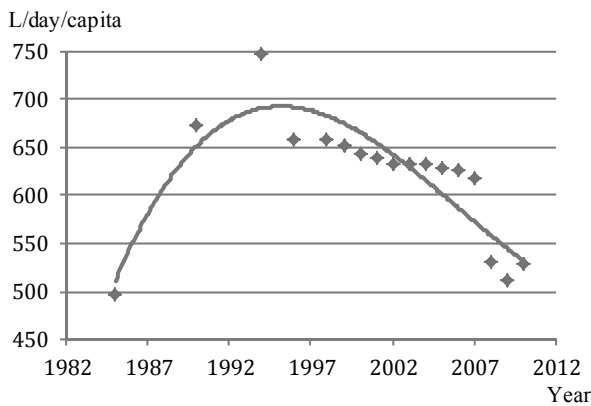


Per capita urban water consumption New Zealand

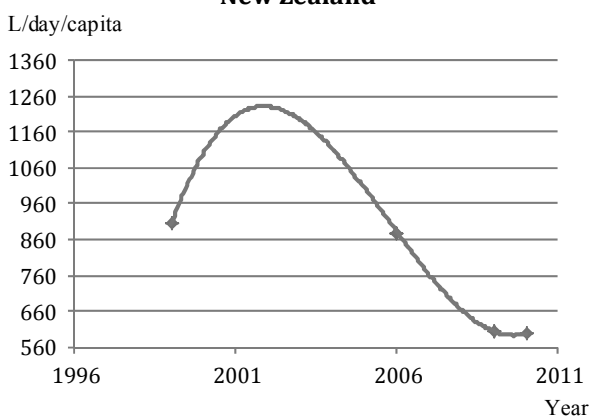

Per capita urban water consumption Spain

L/day/capita

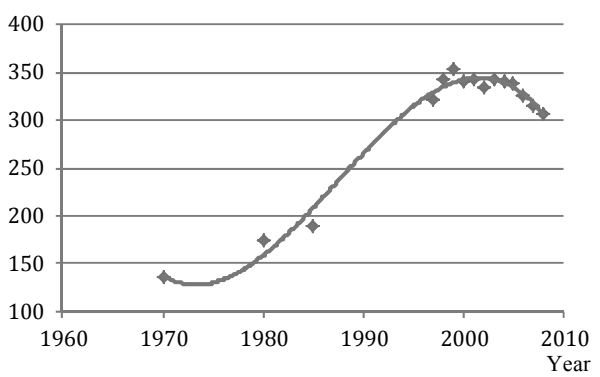

Per capita urban water consumption Switzerland

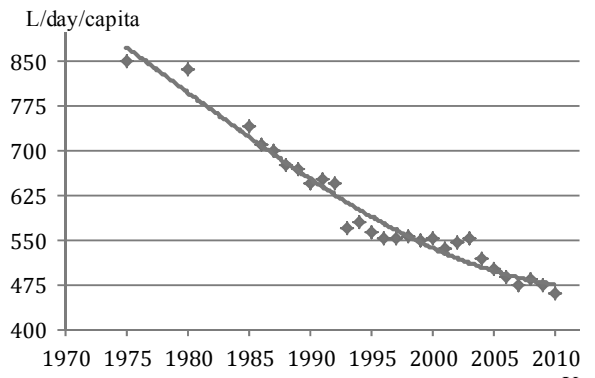

Per capita urban water consumption Portugal

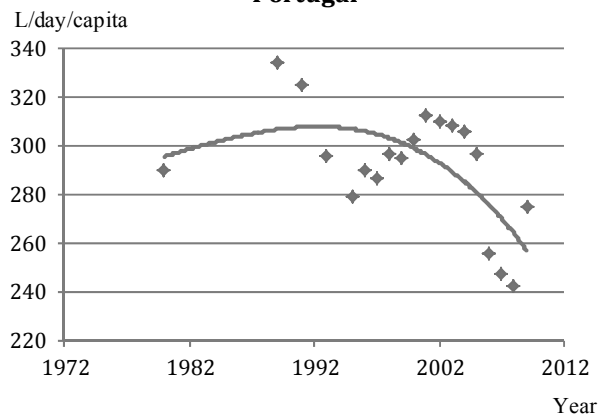

Per capita urban water consumption Sweden

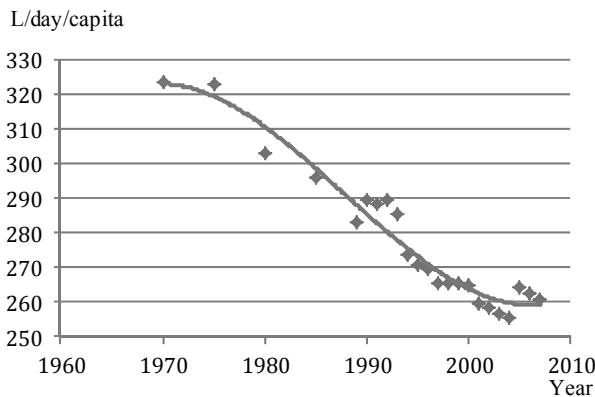

Per capita urban water consumption Turkey

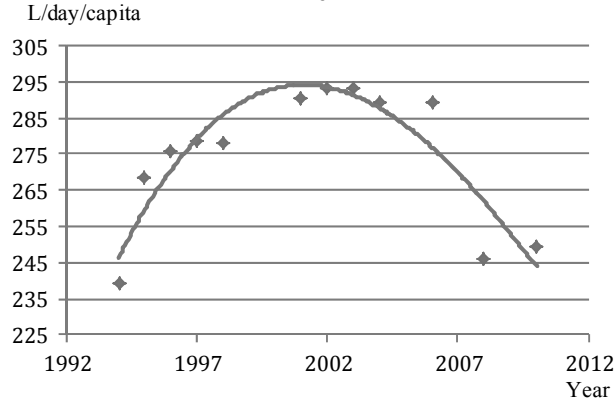



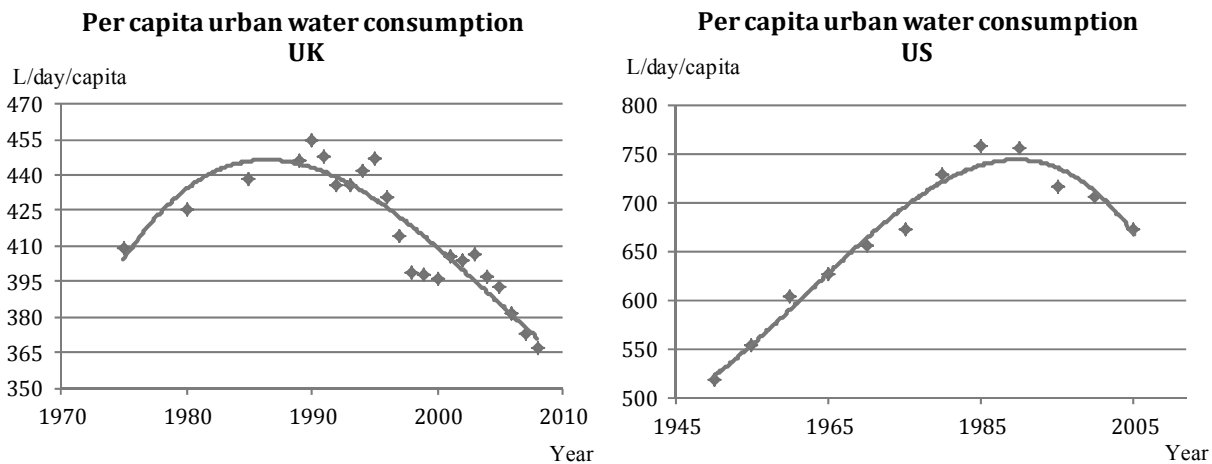


\section{Appendix C: \\ Cubic Water Kuznets Curves in 27 countries for the period of 1960-2010}

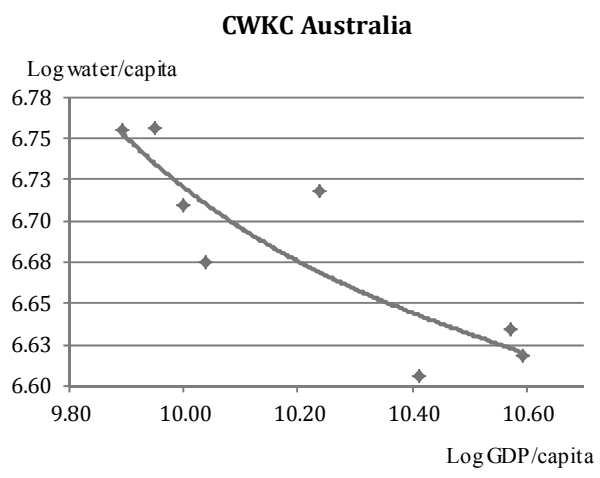

CWKC Belgium

Log water/capita

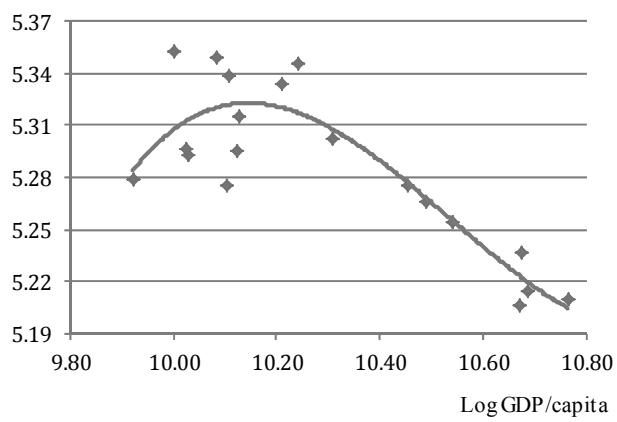

WKC China

Log water/capita

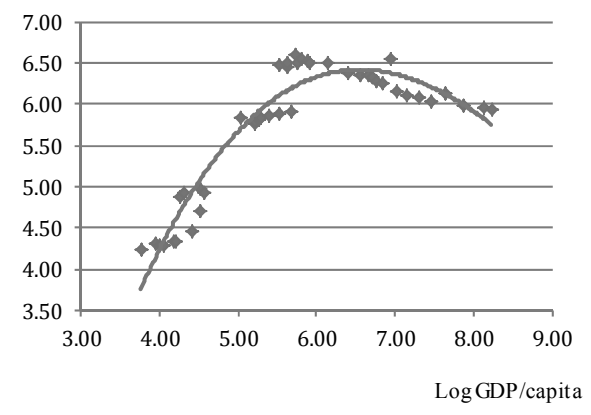

CWKC Austria

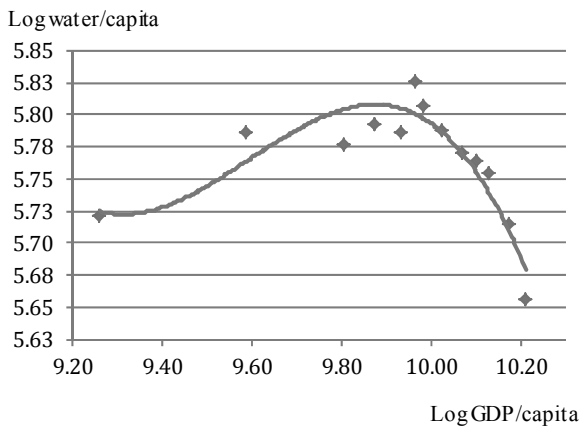

CWKC Canada
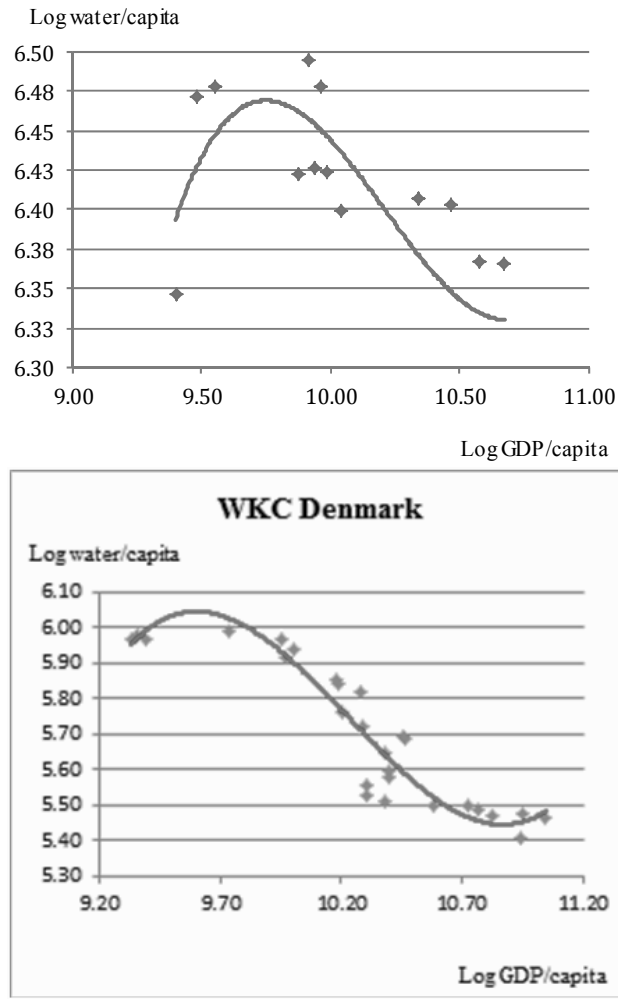
CWKC Finland

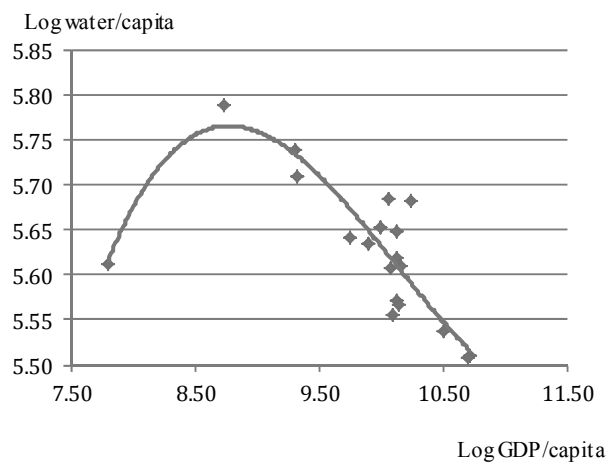

WKC Germany

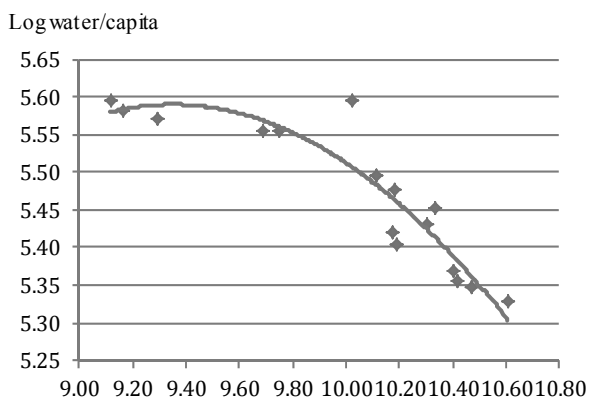

Log GDP/capita

\section{CWKC Iceland}

\section{Log water/capita}

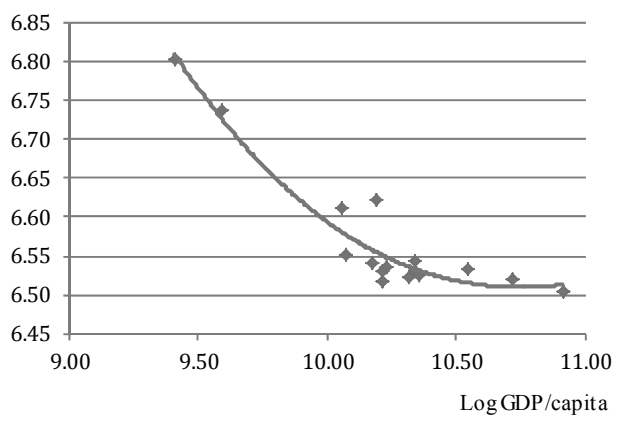

WKC France

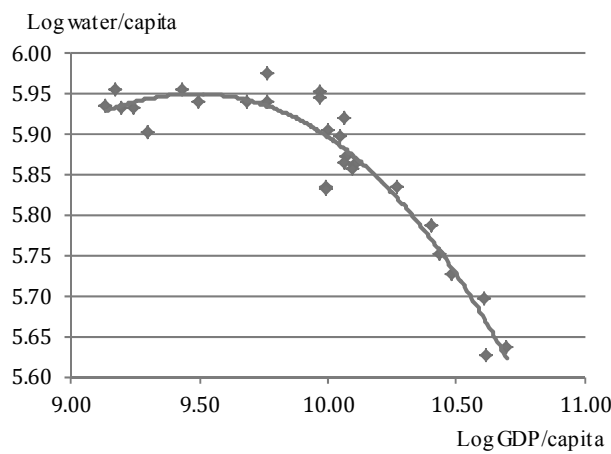

CWKC Greece

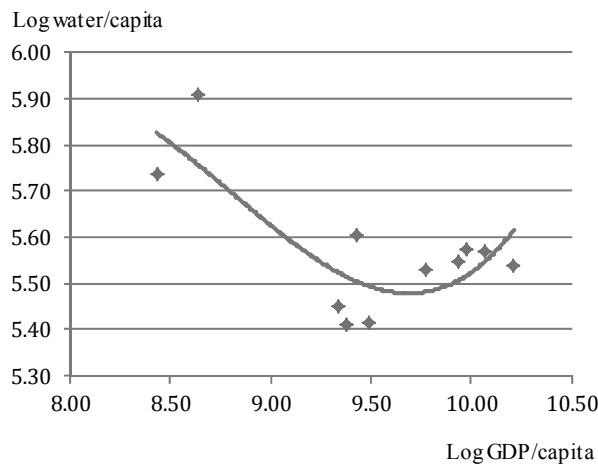

CWKC Ireland

Log water/capita

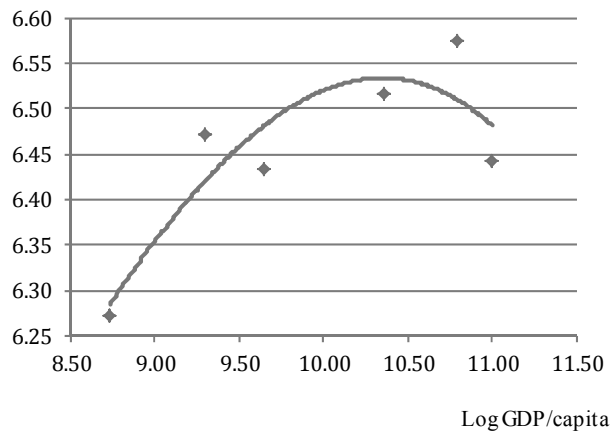


CWKC Italy

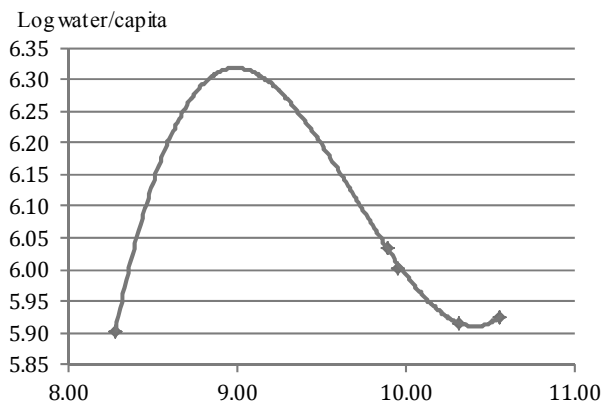

Log GDP/capita

CWKC South Korea

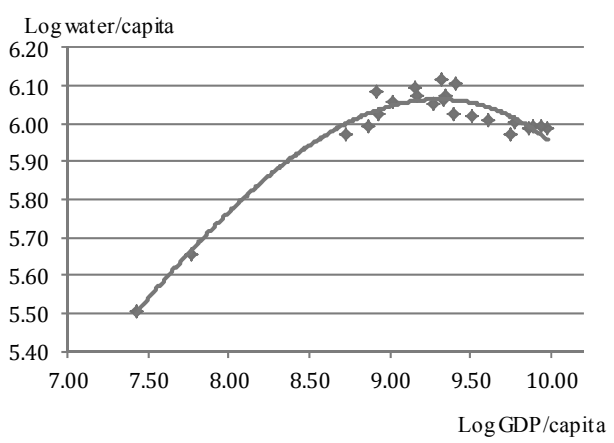

CWKC Mexico

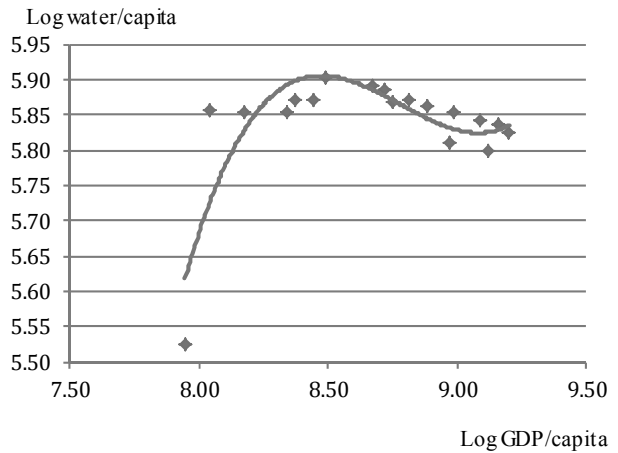

CWKC Japan

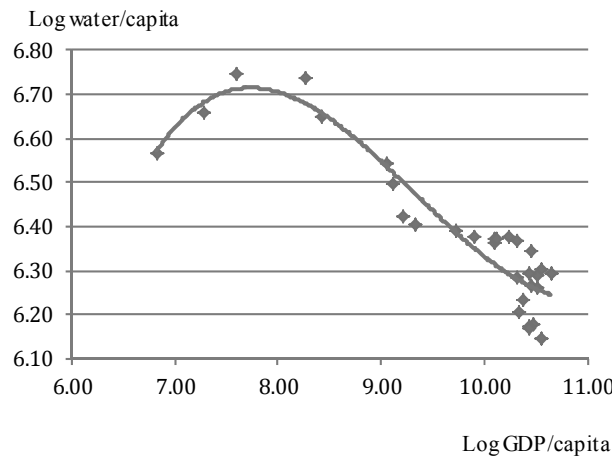

CWKC Luxembourg

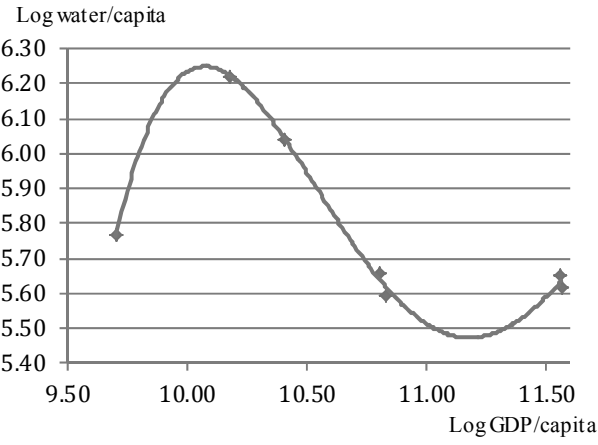

CWKC Netherlands

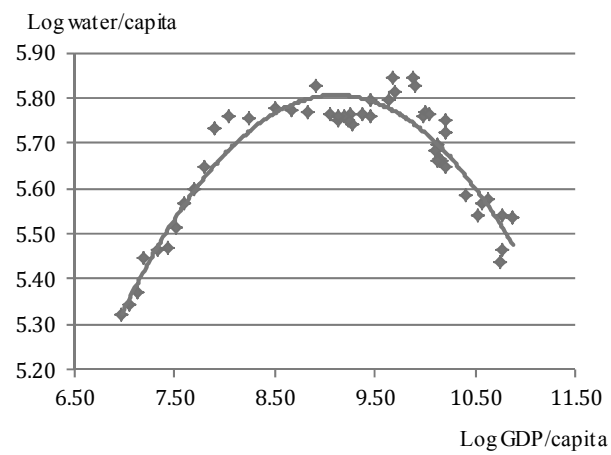


Log water/capita

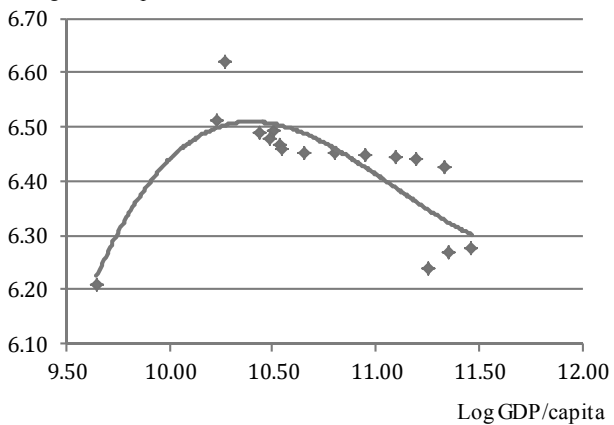

CWKC Portugal

Log water/capita

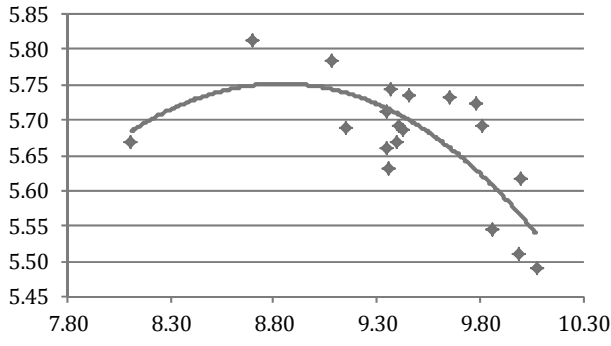

Log GDP/capita

CWKC Sweden

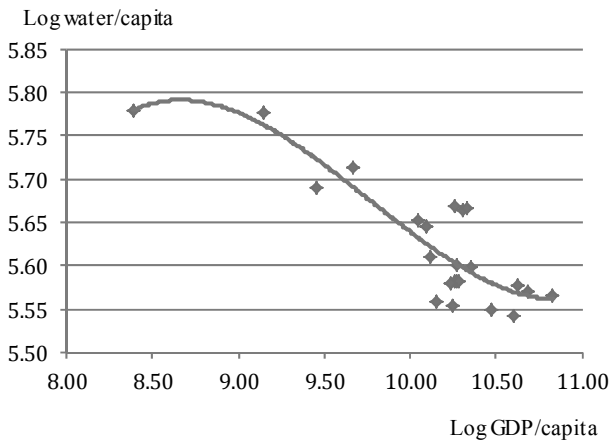

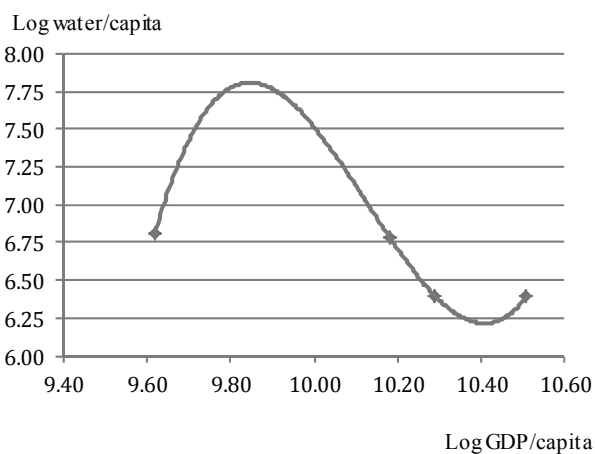

CWKC Spain

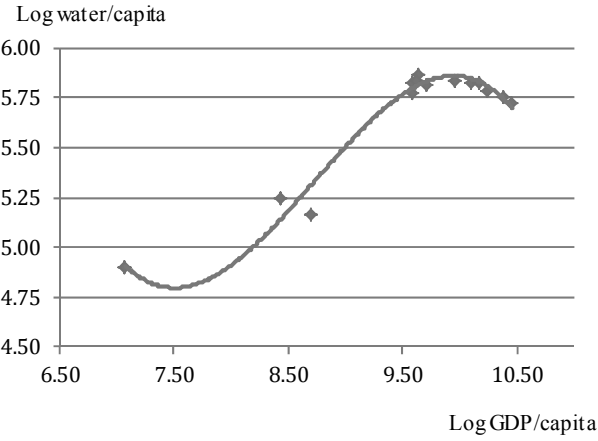

CWKC Switzerland

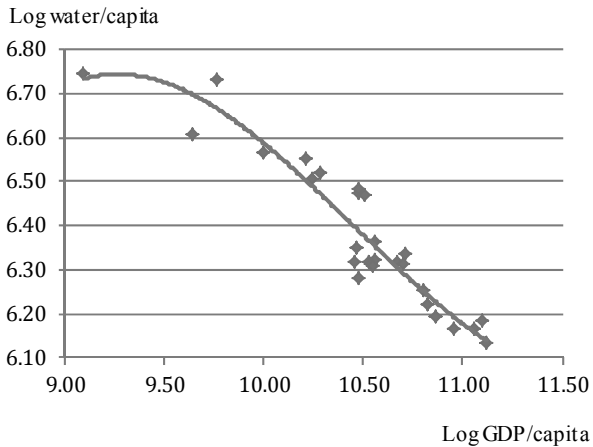


CWKC Turkey

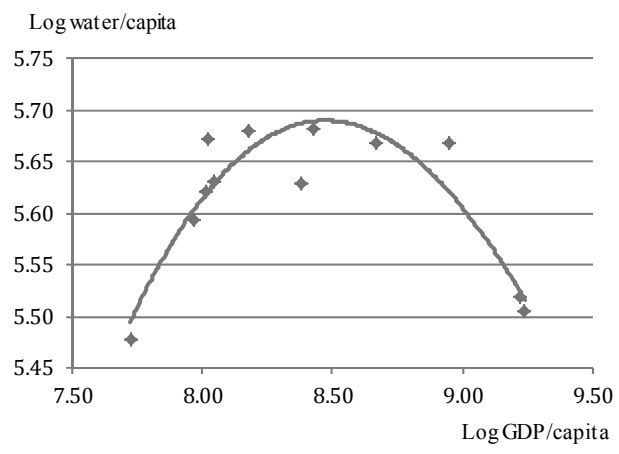

CWKC United States

Log water/capita

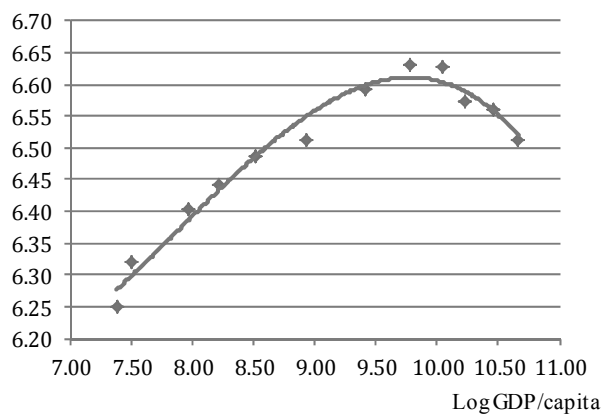

CWKC United Kingdom

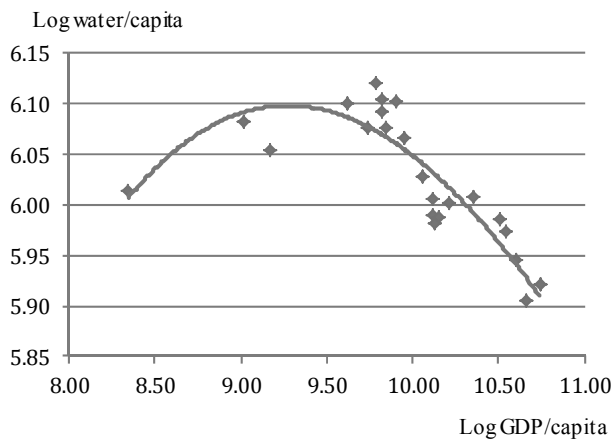




\section{Appendix D}

\section{Two-level ordered logistic regression model}

\section{Step 1: Intercept-only Model}

We start with an intercept-only model. Intercept-only models are used as a null model (baseline model) that serves as a benchmark to which other models are compared. For our study, the intercept-only model is written as follows:

$\eta_{\mathrm{cij}}=\theta_{\mathrm{c}}+\gamma_{00}+\mathrm{u}_{0 \mathrm{j}}$

The variance of the residual errors $u_{0}$ is used to calculate the intraclass correlation. The residual first-level variance is equal to $\frac{\pi^{2}}{3} \approx 3.29$ for our logit model. Modeling the cumulative probabilities $p_{c}^{*}$ makes the last response category as the reference category. As a result, the regression coefficients in the cumulative regression model will have a sign that is opposite to the sign given by an ordinary linear regression.

\section{Step 2: Fixed-effect Model}

In the second step, we extend the null model with fixed effects for the individual level explanatory variables in which the slopes are assumed not to vary across groups. Therefore, we obtain:

$$
\begin{aligned}
& \eta_{c i j}=\theta_{c}+\beta_{0 j}+\beta_{1 j} \text { gender }_{i j}+\beta_{2 j} \text { age }_{i j}+\beta_{3 j} \text { edu }_{i j}+\beta_{4 j} \text { employ }_{i j}+\beta_{5 j} \text { income }_{i j} \\
& +\beta_{6 \mathrm{j}} \text { trust }_{\mathrm{ij}}+\beta_{7 \mathrm{j}} \mathrm{FS}_{\mathrm{ij}}+\beta_{8 \mathrm{j}} \mathrm{GP}_{\mathrm{ij}} \\
& \beta_{0 \mathrm{j}}=\gamma_{00}+\mathrm{u}_{0 \mathrm{j}} \\
& \beta_{1 \mathrm{j}}=\gamma_{10} \\
& \vdots \\
& \beta_{8 \mathrm{j}}=\gamma_{80} \\
& \eta_{\text {cij }}=\theta_{c}+\gamma_{00}+\gamma_{10} \text { gender }_{i j}+\gamma_{20} \text { age }_{i j}+\gamma_{30} \text { edu }_{i j}+\gamma_{40} \text { employ }_{i j}+\gamma_{50} \text { income }_{i j} \\
& +\gamma_{60} \text { trust }_{i j}+\gamma_{70} \mathrm{FS}_{\mathrm{ij}}+\gamma_{80} \mathrm{GP}_{\mathrm{ij}}+\mathrm{u}_{0 \mathrm{j}}
\end{aligned}
$$

\section{Step 3: Fixed-effects Model with group-level variable}

In the third step, we add the group level explanatory variables. This model allows us to examine whether the group-level explanatory variables explain the betweengroup variation in the dependent variable. Therefore, we obtain: 


$$
\begin{aligned}
& \eta_{c i j}=\theta_{c}+\beta_{0 j}+\beta_{1 j} \text { gender }_{i j}+\beta_{2 j} \text { age }_{i j}+\beta_{3 j} \text { edu }_{i j}+\beta_{4 j} \text { employ }_{i j}+\beta_{5 j} \text { income }_{i j} \\
& +\beta_{6 \mathrm{j}} \text { trust }_{\mathrm{ij}}+\beta_{7 \mathrm{j}} \mathrm{FS}_{\mathrm{ij}}+\beta_{8 \mathrm{j}} \mathrm{GP}_{\mathrm{ij}} \\
& \beta_{0 \mathrm{j}}=\gamma_{00}+\gamma_{01} \mathrm{z}_{1 \mathrm{j}}+\mathrm{u}_{0 \mathrm{j}} \\
& \beta_{1 \mathrm{j}}=\gamma_{10} \\
& \beta_{8 \mathrm{j}}=\gamma_{80} \\
& \eta_{\text {cij }}=\theta_{c}+\gamma_{00}+\gamma_{10} \text { gender }_{i j}+\gamma_{20} \text { age }_{i j}+\gamma_{30} \text { edu }_{i j}+\gamma_{40} \text { employ }_{i j}+\gamma_{50} \text { income }_{i j} \\
& +\gamma_{60} \text { trust }_{i j}+\gamma_{70} \mathrm{FS}_{\mathrm{ij}}+\gamma_{80} \mathrm{GP}_{\mathrm{ij}}+\gamma_{01} \mathrm{Z}_{1 \mathrm{j}}+\mathrm{u}_{0 \mathrm{j}}
\end{aligned}
$$

\section{Step 4: Random Coefficient Model}

In the fourth step, we further extend our models with varying slopes-the random effects.

$$
\begin{aligned}
& \eta_{\text {cij }}=\theta_{c}+\beta_{0 j}+\beta_{1 j} \text { gender }_{i j}+\beta_{2 j} \text { age }_{i j}+\beta_{3 j} \text { edu }_{i j}+\beta_{4 j} \text { employ }_{\mathrm{ij}}+\beta_{5 \mathrm{j}} \text { income }_{\mathrm{ij}} \\
& +\beta_{6 \mathrm{j}} \text { trust }_{\mathrm{ij}}+\beta_{7 \mathrm{j}} \mathrm{FS}_{\mathrm{ij}}+\beta_{8 \mathrm{j}} \mathrm{GP}_{\mathrm{ij}} \\
& \beta_{0 \mathrm{j}}=\gamma_{00}+\gamma_{01} \mathrm{Z}_{1 \mathrm{j}}+\mathrm{u}_{0 \mathrm{j}} \\
& \beta_{1 \mathrm{j}}=\gamma_{10}+\mathrm{u}_{1 \mathrm{j}} \\
& \text { : } \\
& \beta_{8 \mathrm{j}}=\gamma_{80}+\mathrm{u}_{8 \mathrm{j}} \\
& \eta_{\text {cij }}=\theta_{c}+\gamma_{00}+\gamma_{10} \text { gender }_{i j}+\gamma_{20} \text { age }_{i j}+\gamma_{30} \text { edu }_{i j}+\gamma_{40} \text { employ }_{i j}+\gamma_{50} \text { income }_{i j} \\
& +\gamma_{60} \text { trust }_{i j}+\gamma_{70} \mathrm{FS}_{\mathrm{ij}}+\gamma_{80} \mathrm{GP}_{\mathrm{ij}}+\gamma_{01} \mathrm{Z}_{1 \mathrm{j}}+\mathrm{u}_{0 \mathrm{j}}+\mathrm{u}_{1 \mathrm{j}} \text { gender }_{\mathrm{ij}} \\
& +\mathrm{u}_{2 \mathrm{j}} \text { age }_{\mathrm{ij}}+\mathrm{u}_{3 \mathrm{j}} \text { edu }_{\mathrm{ij}}+\mathrm{u}_{4 \mathrm{j}} \text { employ }_{\mathrm{ij}}+\mathrm{u}_{5 \mathrm{j}} \text { income }_{\mathrm{ij}}+\mathrm{u}_{6 \mathrm{j}} \text { trust }_{\mathrm{ij}} \\
& +\mathrm{u}_{7 \mathrm{j}} \mathrm{FS}_{\mathrm{ij}}+\mathrm{u}_{8 \mathrm{j}} \mathrm{GP}_{\mathrm{ij}}
\end{aligned}
$$

\section{Step 5: Full Multilevel Regression Model}

In the last step, we run the full multilevel regression model by adding cross-level interactions between explanatory group-level variables and the individual-level explanatory variables that had significant slope variations in step 4, which leads to the full model:

$$
\begin{aligned}
\eta_{\mathrm{cij}}=\theta_{\mathrm{c}}+\beta_{0 \mathrm{j}}+ & \beta_{1 \mathrm{j}} \text { gender }_{\mathrm{ij}}+\beta_{2 \mathrm{j}} \text { age }_{\mathrm{ij}}+\beta_{3 \mathrm{j}} \text { edu }_{\mathrm{ij}}+\beta_{4 \mathrm{j}} \text { employ }_{\mathrm{ij}}+\beta_{5 \mathrm{j}} \text { income }_{\mathrm{ij}} \\
& +\beta_{6 \mathrm{j}} \text { trust }_{\mathrm{ij}}+\beta_{7 \mathrm{j}} \mathrm{FS}_{\mathrm{ij}}+\beta_{8 \mathrm{j}} \mathrm{GP}_{\mathrm{ij}}
\end{aligned}
$$




$$
\begin{aligned}
& \beta_{0 j}=\gamma_{00}+\gamma_{0 q} Z_{q j}+u_{0 j} \\
& \beta_{1 \mathrm{j}}=\gamma_{10}+\gamma_{1 \mathrm{q}} \mathrm{Z}_{\mathrm{qj}}+\mathrm{u}_{1 \mathrm{j}} \\
& \text { ! } \\
& \beta_{8 \mathrm{j}}=\gamma_{80}+\gamma_{81} \mathrm{z}_{8 \mathrm{j}}+\mathrm{u}_{8 \mathrm{j}} \\
& \eta_{\text {cij }}=\left(\theta_{c}+\gamma_{00}+\gamma_{10} \text { gender }_{i j}+\gamma_{20} \text { age }_{i j}+\gamma_{30} \text { edu }_{i j}+\gamma_{40} \text { employ }_{i j}+\gamma_{50} \text { income }_{i j}\right. \\
& +\gamma_{60} \text { trust }_{i j}+\gamma_{70} \mathrm{FS}_{\mathrm{ij}}+\gamma_{80} \mathrm{GP}_{\mathrm{ij}}+\gamma_{11} \mathrm{Z}_{\mathrm{j}} \text { gender }_{\mathrm{ij}}+\gamma_{21} \mathrm{Z}_{\mathrm{j}} \text { age }_{\mathrm{ij}} \\
& +\gamma_{31} Z_{j} \text { edu }_{i j}+\gamma_{41} Z_{j} \text { employ }_{i j}++\gamma_{51} Z_{j} \text { income }_{i j}+\gamma_{61} Z_{j} \text { trust }_{i j} \\
& \left.+\gamma_{71} \mathrm{Z}_{\mathrm{j}} \mathrm{FS}_{\mathrm{ij}}+\gamma_{81} \mathrm{Z}_{\mathrm{j}} \mathrm{GP}_{\mathrm{ij}}+\gamma_{01} \mathrm{Z}_{\mathrm{j}}\right)+\left(\mathrm{u}_{0 \mathrm{j}}+\mathrm{u}_{1 \mathrm{j}} \text { gender }_{\mathrm{ij}}+\mathrm{u}_{2 \mathrm{j}} \mathrm{age}_{\mathrm{ij}}\right. \\
& +\mathrm{u}_{3 \mathrm{j}} \text { edu }_{\mathrm{ij}}+\mathrm{u}_{4 \mathrm{j}} \text { employ }_{\mathrm{ij}}+\mathrm{u}_{5 \mathrm{j}} \text { income }_{\mathrm{ij}}+\mathrm{u}_{6 \mathrm{j}} \text { trust }_{\mathrm{ij}}+\mathrm{u}_{7 \mathrm{j}} \mathrm{FS}_{\mathrm{ij}} \\
& \left.+\mathrm{u}_{8 \mathrm{j}} \mathrm{GP}_{\mathrm{ij}}\right)
\end{aligned}
$$




\section{Two-level logistic regression model for dichotomous responses}

\section{Step 1: Intercept-only Model}

We start with an intercept-only model. Intercept-only models are used as a null model (baseline model) that serves as a benchmark to which other models are compared. For our study, the intercept-only model is written as follows:

$\eta_{\mathrm{ij}}=\gamma_{00}+\mathrm{u}_{0 \mathrm{j}}$

\section{Step 2: Fixed-effect Model}

In the second step, we extend the null model with fixed effects for the individual level explanatory variables in which the slopes are assumed not to vary across groups. Therefore, we obtain:

$$
\begin{gathered}
\eta_{\mathrm{ij}}=\beta_{0 \mathrm{j}}+\beta_{1 \mathrm{j}} \text { gender }_{\mathrm{ij}}+\beta_{2 \mathrm{j}} \text { age }_{\mathrm{ij}}+\beta_{3 \mathrm{j}} \text { edu }_{\mathrm{ij}}+\beta_{4 \mathrm{j}} \text { employ }_{\mathrm{ij}}+\beta_{5 \mathrm{j}} \text { income }_{\mathrm{ij}}+\beta_{6 \mathrm{j}} \text { trust }_{\mathrm{ij}} \\
+\beta_{7 \mathrm{j}} \mathrm{FS}_{\mathrm{ij}}+\beta_{8 \mathrm{j}} \mathrm{GP}_{\mathrm{ij}}
\end{gathered}
$$

$$
\begin{aligned}
& \beta_{0 \mathrm{j}}=\gamma_{00}+\mathrm{u}_{0 \mathrm{j}} \\
& \beta_{1 \mathrm{j}}=\gamma_{10} \\
& \quad \vdots \\
& \beta_{8 \mathrm{j}}=\gamma_{80} \\
& \begin{aligned}
\eta_{\mathrm{ij}} & =\gamma_{00}+\gamma_{10} \text { gender }_{\mathrm{ij}}+\gamma_{20} \text { age }_{\mathrm{ij}}+\gamma_{30} \text { edu }_{\mathrm{ij}}+\gamma_{40} \text { employ }_{\mathrm{ij}}+\gamma_{50} \text { income }_{\mathrm{ij}} \\
& \quad+\gamma_{60} \text { trust }_{\mathrm{ij}}+\gamma_{70} \mathrm{FS}_{\mathrm{ij}}+\gamma_{80} \mathrm{GP}_{\mathrm{ij}}+\mathrm{u}_{0 \mathrm{j}}
\end{aligned}
\end{aligned}
$$

\section{Step 3: Fixed-effect Model with group-level variable}

In the third step, we add the high level explanatory variables. This model allows us to examine whether the group-level explanatory variables explain the betweengroup variation in the dependent variable. Therefore, we obtain:

$$
\begin{aligned}
& \eta_{i j}=\beta_{0 j}+\beta_{1 j} \text { gender }_{i j}+\beta_{2 j} \text { age }_{i j}+\beta_{3 j} \text { edu }_{i j}+\beta_{4 j} \text { employ }_{i j}+\beta_{5 j} \text { income }_{i j}+\beta_{6 j} \text { trust }_{i j} \\
& +\beta_{7 \mathrm{j}} \mathrm{FS}_{\mathrm{ij}}+\beta_{8 \mathrm{j}} \mathrm{GP}_{\mathrm{ij}} \\
& \beta_{0 \mathrm{j}}=\gamma_{00}+\gamma_{01} \mathrm{Z}_{1 \mathrm{j}}+\mathrm{u}_{0 \mathrm{j}} \\
& \beta_{1 \mathrm{j}}=\gamma_{10} \\
& \beta_{8 \mathrm{j}}=\gamma_{80}
\end{aligned}
$$




$$
\begin{gathered}
\eta_{\mathrm{ij}}=\gamma_{00}+\gamma_{10} \text { gender }_{\mathrm{ij}}+\gamma_{20} \text { age }_{\mathrm{ij}}+\gamma_{30} \text { edu }_{\mathrm{ij}}+\gamma_{40} \text { employ }_{\mathrm{ij}}+\gamma_{50} \text { income }_{\mathrm{ij}} \\
+\gamma_{60} \text { trust }_{\mathrm{ij}}+\gamma_{70} \mathrm{FS}_{\mathrm{ij}}+\gamma_{80} \mathrm{GP}_{\mathrm{ij}}+\gamma_{01} \mathrm{Z}_{1 \mathrm{j}}+\mathrm{u}_{0 \mathrm{j}}
\end{gathered}
$$

\section{Step 4: Random Coefficient Model}

In the fourth step, we further extend our models with varying slopes-the random effects.

$$
\begin{aligned}
& \eta_{i j}=\beta_{0 j}+\beta_{1 j} \text { gender }_{i j}+\beta_{2 j} \text { age }_{i j}+\beta_{3 j} \text { edu }_{i j}+\beta_{4 j} \text { employ }_{i j}+\beta_{5 j} \text { income }_{i j}+\beta_{6 j} \text { trust }_{i j} \\
& +\beta_{7 \mathrm{j}} \mathrm{FS}_{\mathrm{ij}}+\beta_{8 \mathrm{j}} \mathrm{GP}_{\mathrm{ij}} \\
& \beta_{0 \mathrm{j}}=\gamma_{00}+\gamma_{01} \mathrm{Z}_{1 \mathrm{j}}+\mathrm{u}_{0 \mathrm{j}} \\
& \beta_{1 \mathrm{j}}=\gamma_{10}+\mathrm{u}_{1 \mathrm{j}} \\
& \beta_{8 \mathrm{j}}=\gamma_{80}+\mathrm{u}_{8 \mathrm{j}} \\
& \eta_{\mathrm{ij}}=\gamma_{00}+\gamma_{10} \text { gender }_{\mathrm{ij}}+\gamma_{20} \text { age }_{\mathrm{ij}}+\gamma_{30} \mathrm{edu}_{\mathrm{ij}}+\gamma_{40} \text { employ }_{\mathrm{ij}}+\gamma_{50} \text { income }_{\mathrm{ij}} \\
& +\gamma_{60} \text { trust }_{i j}+\gamma_{70} \mathrm{FS}_{\mathrm{ij}}+\gamma_{80} \mathrm{GP}_{\mathrm{ij}}+\gamma_{01} \mathrm{Z}_{1 \mathrm{j}}+\mathrm{u}_{0 \mathrm{j}}+\mathrm{u}_{1 \mathrm{j}} \text { gender }_{\mathrm{ij}} \\
& +u_{2 j} \text { age }_{i j}+u_{3 j} \text { edu }_{i j}+u_{4 j} \text { employ }_{i j}+u_{5 j} \text { income }_{i j}+u_{6 j} \text { trust }_{i j} \\
& +\mathrm{u}_{7 \mathrm{j}} \mathrm{FS}_{\mathrm{ij}}+\mathrm{u}_{8 \mathrm{j}} \mathrm{GP}_{\mathrm{ij}}
\end{aligned}
$$

\section{Step 5: Full Multilevel Regression Model}

In the last step, we run the full multilevel regression model by adding cross-level interactions between explanatory group-level variables and the individual-level explanatory variables that had significant slope variations in step 4, which leads to the full model:

$$
\begin{aligned}
& \eta_{i j}=\beta_{0 j}+\beta_{1 j} \text { gender }_{i j}+\beta_{2 j} \text { age }_{i j}+\beta_{3 j} \text { edu }_{i j}+\beta_{4 j} \text { employ }_{i j}+\beta_{5 j} \text { income }_{i j}+\beta_{6 j} \text { trust }_{i j} \\
& +\beta_{7 \mathrm{j}} \mathrm{FS}_{\mathrm{ij}}+\beta_{8 \mathrm{j}} \mathrm{GP}_{\mathrm{ij}} \\
& \beta_{0 j}=\gamma_{00}+\gamma_{0 q} Z_{q j}+u_{0 j} \\
& \beta_{1 \mathrm{j}}=\gamma_{10}+\gamma_{1 \mathrm{q}} \mathrm{Z}_{\mathrm{qj}}+\mathrm{u}_{1 \mathrm{j}} \\
& \beta_{8 \mathrm{j}}=\gamma_{80}+\gamma_{81} \mathrm{Z}_{8 \mathrm{j}}+\mathrm{u}_{8 \mathrm{j}}
\end{aligned}
$$




$$
\begin{aligned}
& \eta_{\mathrm{ij}}=\left(\gamma_{00}+\gamma_{10} \text { gender }_{\mathrm{ij}}+\gamma_{20} \text { age }_{\mathrm{ij}}+\gamma_{30} \text { edu }_{\mathrm{ij}}+\gamma_{40} \text { employ }_{\mathrm{ij}}+\gamma_{50} \text { income }_{\mathrm{ij}}\right. \\
&+\gamma_{60} \text { trust }_{\mathrm{ij}}+\gamma_{70} \mathrm{FS}_{\mathrm{ij}}+\gamma_{80} \mathrm{GP}_{\mathrm{ij}}+\gamma_{11} \mathrm{Z}_{\mathrm{j}} \text { gender }_{\mathrm{ij}}+\gamma_{21} \mathrm{Z}_{\mathrm{j}} \text { age }_{\mathrm{ij}} \\
&+\gamma_{31} \mathrm{Z}_{\mathrm{j}} \text { edu }_{\mathrm{ij}}+\gamma_{41} \mathrm{Z}_{\mathrm{j}} \text { employ }_{\mathrm{ij}}++\gamma_{51} \mathrm{Z}_{\mathrm{j}} \text { income }_{\mathrm{ij}}+\gamma_{61} \mathrm{Z}_{\mathrm{j}} \text { trust }_{\mathrm{ij}} \\
&\left.+\gamma_{71} \mathrm{Z}_{\mathrm{j}} \mathrm{FS}_{\mathrm{ij}}+\gamma_{81} \mathrm{Z}_{\mathrm{j}} \mathrm{GP}_{\mathrm{ij}}+\gamma_{01} \mathrm{Z}_{\mathrm{j}}\right) \\
&+\left(\mathrm{u}_{0 \mathrm{j}}+\mathrm{u}_{1 \mathrm{j}} \text { gender }_{\mathrm{ij}}+\mathrm{u}_{2 \mathrm{j}} \text { age }_{\mathrm{ij}}+\mathrm{u}_{3 \mathrm{j}} \text { edu }_{\mathrm{ij}}+\mathrm{u}_{4 \mathrm{j}} \text { employ }_{\mathrm{ij}}\right. \\
&\left.+\mathrm{u}_{5 \mathrm{j}} \text { income }_{\mathrm{ij}}+\mathrm{u}_{6 \mathrm{j}} \text { trust }_{\mathrm{ij}}+\mathrm{u}_{7 \mathrm{j}} \mathrm{FS}_{\mathrm{ij}}+\mathrm{u}_{8 \mathrm{j}} \mathrm{GP}_{\mathrm{ij}}\right)
\end{aligned}
$$




\section{Valorization}

Water is the core of life, and it is one of the most widespread elements on our planet. Historically, water gestates and nourishes human civilisations. Humans used to take water for granted; however, today, water scarcity affects every continent, and water has become one of the most precious resources on the earth. Currently, approximately 700 million people in 43 countries suffer from water scarcity. Unfortunately, the number is still growing. Under the existing climate change scenario, almost half of the world's population will be living in area of high water stress by 2030 .

In many places, especially in the developing world, water scarcity is threatening social and economic development; in some extreme cases, the scarcity is seriously affecting peoples' health and lives. In those places, rapid urbanisation, population expansion and environmental deterioration further aggravate the problem in their urban areas. The need of water for economic development and the necessity of environmental protection pose a severe challenge to the governments. Hence, satisfying the water demands of different users with high quality services while maintaining sustainable development and utilisation of water resources is the core target of urban water management in the developing world.

How to achieve this target is the concern of water authorities and policy-makers in many developing countries. In this thesis, through a comprehensive analysis of urban water management reform in China, we try to shed new light on the problem. We address two important questions of urban water management: 1) What is the trajectory of urban water consumption and what are the determinants of its formation?; and 2) what are the determinants of successful urban water management reform in developing countries and the roles of governments, businesses and individuals?

To answer the first question, we investigate the urban water consumption patterns of 27 countries during 1960-2010. We find that per capita urban water consumption has an $\mathrm{N}$-shaped relationship with GDP per capita, which we name as the Cubic Water Kuznets Curve (CWKC) and identify three stages of this relationship. During the first stage, per capita urban water consumption increases with economic development and reaches a peak consumption volume. During the second stage, water consumption per capita decreases despite continuously increasing GDP per capita. During the third stage, as economic development reaches a very high level, water consumption per capita stabilizes or begins to increase slightly. 
This finding shows that the turning point and the determinants of the CWKC become important to the developing countries. It demonstrates that the long-term water policies that are properly designed and rigorously implemented can mitigate the stress of water demand in urban areas. These developing countries can then reach an earlier inflection point in the CWKC, thus improving the balance between economic development and environment preservation.

In the remaining part of the thesis, based on the triangular interrelated relationship framework among the government, businesses and individuals, we conduct a comprehensive study of urban water management reform in China with a focus of policy analysis, in which we attempt to answer our second research question.

The policy analysis in Chapter 3 is the first comprehensive research on the neoliberalist policy adoption in the largest developing economy-China since the reform in 1979. Although neo-liberalist reform of water sector was adopted by many countries, both in the North and the South, developing countries encountered many troubles and failures during reform when they simply adopted the reform of the North. It is arguable that the different development stages and endowment conditions in developing countries require modification of the North's neo-liberalist strategies on urban water management reform. Our study demonstrates the success of the urban water management reform in China and provides in-depth analysis on the reform. It is thus not only useful for the Chinese water authorities and policy-makers but also valuable to the water authorities and policy-makers in other developing countries.

Although water privatization is already adopted in many countries since 1990s, the debate on water privatization is still fierce. The advocators believe that water privatization can address the problems of inefficiency, lack of financial resources and the corruption in the publicly owned water sector, whereas the opponents argue that the profit-seeking character of private sector will lead to unaffordable water price and destroy the public good character of water. By the end of 1990s, the dramatic withdrawal of multinational water corporations from the South and a number of conflicts taking place in these countries seem to suggest water privatization doesn't work in the South. However, on the other hand, we have witnessed the active participation of multinational water corporations in China and the fast growth of Chinese water sector. Our firm level empirical analysis of Chinese water sector in the Chapter 4 based on Stochastic Frontier Analysis and Parametric Generalized Malmquist productivity index demonstrate the success of the privatization reform in the country.

The ownership of water sector varies in different countries. In some countries, such as the UK and France, water sector is completely owned by the private firms. While in some other countries, such as The Netherlands and Norway, water sector remains in the public hands. Water sectors in many other countries have mixed ownership. Each model has successful examples and failure cases. Therefore, it is irrelevant to discuss whether the water privatization is effective or not without considering the economic conditions, the government capacity and the natural 
endowments of a country. Our study shows that privatization could contribute to the productivity growth of water sector in the developing world, under strong policy intervention and government supervision. Our empirical research in Chapter 4 is the first study examining the productivity change of the Chinese water sector based on firm-level data and contributes to the empirical literature on productivity in the water sector.

Water conservation is promoted through public participation policies in China. The synthesis of individual behaviour determines the outcome of an entire society. Individuals' behaviour is affected by fiscal incentives and social obligations; in the long-term, their behaviour is largely determined by their intrinsic motivations. Therefore, by examining individuals' environmental concern and water consumption behaviour evolution and related impact factors, our study in Chapter 5 provides a much needed evaluation of public participation policy in the past and offers recommendation to future improvement. Based on the four waves of the World Value Survey (WVS) data, we in Chapter 5 show that the public participation policies stimulate individuals' environmental concern and water conservation behaviour in China. Contrary to previous studies that focused on the individual level only, we adopt multilevel regression models to investigate the determinants of environmental concern at both the individual and provincial level, providing more robust evidences.

In summary, in this dissertation, we conduct an in-depth analysis on the pattern of urban water consumption and provide a comprehensive investigation of the urban water management reforms in China. The academic community, water authorities and policy-makers in developing countries are the audience of our research. The Chinese water authorities can learn from our research and address the problems in the future policy design and implementations. The water authorities and policymakers in other developing countries can learn from the Chinese experience and better adjust their water management strategies based on their local circumstances.

In addition, our study in Chapter 4 provides a useful tool for water policy-makers and water authorities to evaluate and regulate the sector. Water policy-makers can use our method to gain insights into the efficiency of water firms during policy implementations. In fact, the Chinese government and water authorities have launched a pilot project to construct a benchmarking system in the water sector in China. Our research and methodology can serve as a valuable example for such a system.

Our finding in Chapter 5 is very valuable to policy-makers, especially to those in developing countries. By recognising the existence of an $\mathrm{N}$-shaped relationship between environmental concern and per capita GDP, policy-makers can focus on the second stage of the environmental concern curve, namely, the period when the environmental concern decreases with income. Specific policies and more effort should be used to shorten that period as much as possible. The Multilevel Analysis used in this Chapter can also be used by the policy-makers to monitor and analyze 
the change of citizens' environmental concern over time, which can provide further guidance to policy design and implementations. 


\section{Curriculum Vitae Jinjin Zhao}

Jinjin Zhao was born on August 28, 1983 in Tianjin, China. She attended primary school between 1989 and 1995 at the Elementary School Affiliated to Renmin University of China and The High School Affiliated to Renmin University of China between 1995 and 2001 in Beijing.

She holds a B.Eng. in Environmental Engineering from Southeast University, Nanjing, China, with main focus on water treatment and wastewater treatment. Later she obtained a M.A. in Environmental Economics and Management from Università Bocconi, Italy. Between 2007 and 2008, she worked in A2A Group in Italy, mainly responsible for drafting environmental reports and water management. Between 2008 and 2009, she worked at DMT Environmental Technology in The Netherlands as a sales engineer. In December 2009, she joined the UNU-MERIT as a PhD fellow. Her main research interests include sustainable development in urban area of developing countries, particularly water management and governance in urban area of transitional economies. 


\section{UNITED NATIONS UNIVERSITY}

\section{UNU-MERIT}

\section{5}

\section{Jinjin Zhao}

Urban water management reform: The case of China

\section{4}

\section{Dirk Crass}

The Impact of Brands on Innovation and Firm Performance: Empirical Evidence from Germany

\section{Samyukta Bhupatiraju}

The Geographic Dimensions of Growth and Development

\section{François Lafond}

The evolution of knowledge systems

\section{Annalisa Primi}

Promoting Innovation in Latin America: What Countries Have Learned (and What They Have Not) in Designing and Implementing Innovation and Intellectual Property Policies

\section{Fatoumata Lamarana Diallo}

Evaluation of Meal and Deworming Programs for Primary Schools in Rural Senegal

\section{3}

\section{Anant Kamath}

Information Sharing through Informal Interaction in Low-Tech Clusters

\section{Flavia Pereira de Carvalho}

What we talk about when we talk about Brazilian Mulitantionals: an investigation on Brazilian FDI, economic structure, innovation and the relationship between them

\section{Jun Hou}

Complementarity in Innovation and Development: A

Cross-country Comparison

\section{Rufin Baghana}

Impacts of Government Incentives to R\&D, Innovation and Productivity:

A Microeconometric Analysis of the Québec Case

\section{Lilia I. Stubrin}

High-Tech Activities in Emerging Countries: A Network perspective on the Argentinean biotech activity

\section{2}

\section{Abdul Waheed}

Innovation Determinants

and Innovation as a Determinant:

Evidence from Developing Countries

\section{Bilal Mirza}

Energy Poverty and Rural Energy Markets in Pakistan

\section{Benjamin Engelstätter}

Enterprise Software and Video Games: An Empirical Analysis

\section{Fulvia Farinelli}

Natural Resources, Innovation and Export Growth: The Wine Industry in Chili and Argentina

\section{Rodolfo Lauterbach}

Innovation in Manufacturing: From Product Variety and Labor Productivity Growth to Economic Development in Chile

\section{Kirsten Wiebe}

Quantitative Assessment of Sustainable Development and Growth in Sub-Saharan Africa.

\section{Julio Miguel Rosa}

Organizational Strategies, Firms' Performance and Spatial Spillovers. The Canadian Case in Research and Development.

\section{Johannes Wilhelmus Marie Boels}

Joseph Schumpeter, honderd jaar economische ontwikkeling. Een historisch-theoretische beschouwing. 
2011

\section{Daniel Vertesy}

Interrupted Innovation: Emerging economies in the structure of the global aerospace industry.

\section{Tina Saebi}

Successfully managing alliance portfolios: an alliance capability view.

\section{Nora Engel}

Tuberculosis in India - A case of innovation and control.

\section{Evans Mupela}

Connectivity and growth in Sub-Saharan Africa: The role of communication satellites

\section{Nantawan Kwanjai}

Cross cultural intelligence amid intricate cultural webs: A tale of the UnDutchables in the land of 1002 smiles

\section{Lina Sonne}

Innovation in Finance to Finance Innovation: Supporting pro-poor entrepreneur-based innovation

2010

\section{Fernando Santiago}

Human Resources Management Practices and Learning for Innovation in Developing Countries: Pharmaceutical Firms in Mexico

\section{Zakaria Babutsidze}

Essays on Economies with Heterogenous Interacting Consumers

\section{Bertha Vallejo}

Learning and Innovation Under Changing Market Conditions: The Auto Parts Industry in Mexico

\section{Donatus Ayitey}

Technical Change, Competitiveness and Poverty Reduction: A Study of the Ghanaian Apparel Industry

\section{Sergey Fillipov}

Multinational Subsidiary Evolution: Corporate Change in New EU Member States

\section{Asel Doranova}

Technology Transfer and Learning under the Kyoto regime; Exploring the Technological Impact of CDM projects in developing countries

\section{9}

\section{Alexis Habiyaremye}

From Primary Commodity Dependence to Diversification and Growth". "Absorptive Capacity and Technological Catch Up in Botswana and Mauritius".

\section{Yoseph Getachew}

The Role of Public Capital in Economic Development

\section{Sandra Leitner}

Embodied Technological Change and Patterns of Investment in Austrian Manufacturing

\section{Semih Akçomak}

The Impact of Social Capital on Economic and Social Outcomes

\section{Abraham Garcia}

The Role of Demand in Technical Change

\section{Saurabh Arora}

Coherence in socio-technical systems: a network perspective on the innovation process

\section{8}

\section{Rutger Daems}

Medicines for the developing world

\section{Johannes Hanel}

Assessing Induced Technology: Sombart's

Understanding of Technical Change in the History of Economics

\section{Rifka Weehuizen}

Mental Capital: the economic significance of mental health

\section{Danielle Cloodt}

The relationship between R\&D partnership formation, social embeddedness and innovative performance

\section{Sabine Fuss}

Sustainable Energy Development under Uncertainty 


\section{Tobias Kronenberg}

Reconciling Environmental Conservation with Economic Prosperity: The Feasibility of Double Dividends in the Short and Long Run

\section{Viktoria Kravtsova}

Assessing the Impact of Foreign Direct Investment in Transition Economies

\section{Suhail Sultan}

The Competitive Advantage of Small and Medium Sized Enterprises: The Case of Jordan's Natural Stone Industry

\section{6}

\section{Bulat Sanditov}

Essays on Social Learning and Imitation

\section{Mamata Parhi}

Dynamics of New Technology Diffusion: A Study of the Indian Automotive Industry

\section{Andreas Reinstaller}

Social structures and the innovation process: Their role in the demand of firms and consumers

\section{Rose Kiggundu}

Innovation systems and development: the journey of a Beleaguered Nile Perch Fishery in Uganda

\section{Thomas Pogue}

The Evolution of Research Collaboration in South African Gold Mining: 1886-1933

\section{Geoffrey Gachino}

Foreign Direct Investment, Spillovers and Innovation: The Case of Kenyan Manufacturing Industry

\section{0. Önder Nomaler}

Technological Change, International Trade and Growth: An Evolutionary, Multi-Agents-Based Modeling Approach

\section{5}

\section{Samia Satti Osman Mohamed-Nour} Change and Skill Development in the Arab Gulf Countries
Intellectual Property Rights: Economics and Policy Analysis

\section{Daniel Dalohoun}

The relationship between $R \& D$ partnership formation, social embeddedness and innovative performance: a multi-level approach of social embeddedness

\section{Müge Ozman}

Networks, Organizations and Knowledge

\section{Bas Straathof}

Product variety and economic growth: The counteracting effects of scale and idiosyncrasy

\section{Wilfred Schoenmakers}

Knowledge Flows between Multinational Companies: A Patent Data Analysis

\section{Myriam Cloodt} Mergers and Acquisitions (M\&As) in High-Tech Industries: Measuring the Post-M\&A Innovative Performance of Companies

\section{4}

\section{Paola Criscuolo}

R\&D Internationalisation and Knowledge Transfer. Impact on MNEs and their Home Countries

\section{Maarten Verkerk}

Trust and Power on the Shop Floor

\section{Gottfried Leibbrandt}

Adoption, harmonization and succession of network technologies across countries

\section{Mark Sanders}

Skill Biased Technical change - Its Origins, the Interaction with the Labour Market and Policy Implications

\section{3}

\section{Nadine Roijakkers}

Inter-firm cooperation in high-tech industries: a study of R\&D partnerships in pharmaceutical biotechnology

\section{Viki Sonntag}

Speed, Scale and Sustainability 
26. Masaru Yarime

From End-of-Pipe Technology to Clean Technology

\section{Stéphane Malo}

The combinatorial Chemistry Revolution -

Sustaining a Superior Performance Position through Technological Learning

\section{2}

\section{Annelies Hogenbirk}

Determinants of Inward Foreign Direct Investment: the Case of the Netherlands

\section{1}

\section{John Adeoti}

Technology Investment in Pollution Control in SubSaharan Africa: The Case of the Nigerian

Manufacturing Industry

\section{Edward Huizenga}

Innovation Management: How Frontrunners Stay Ahead. An Empirical Study on Key Success Factors in the ICT sector

\section{0}

\section{Machiel van Dijk}

Technological Change and the Dynamics of Industries. Theoretical Issues and Empirical evidence from Dutch Manufacturing

\section{9}

\section{Jan Cobbenhagen}

Managing Innovation at the Company Level: A Study on Non-Sector-Specific Success Factors

\section{Marjolein Caniëls}

Regional Growth Differentials: The Impact of Locally Bounded Knowledge Spillovers

\section{8}

\section{Aldo Geuna}

Resource allocation and knowledge production: Studies in the economics of university research

\section{6}

\section{Reinoud Joosten}

Dynamics, Equilibria, and Values

\section{Hugo Kruiniger}

Investment, R\&D, and the Financing Decisions of the Firm

\section{5}

\section{Hans van Meijl}

Endogenous Technological Change: The Case of Information Technology. Theoretical Considerations and Empirical Results

\section{René Kemp}

Environmental Policy and Technical Change. A Comparison of the Technological Impact of Policy Instruments

\section{Rohini Acharya}

The Impact of New Technologies on Economic Growth and Trade. A Case Study of Biotechnology

\section{Geert Duysters}

The Evolution of Complex Industrial Systems. The Dynamics of Major IT Sectors

\section{Marjan Groen}

Technology, Work and Organisation, A Study of the Nursing Process in Intensive Care Units

\section{4}

\section{Huub Meijers}

On the Diffusion of Technologies in a Vintage Framework; Theoretical Considerations and Empirical Results

\section{Theon van Dijk}

The Limits of Patent Protection. Essays on the Economics of Intellectual Property Rights

\section{Hans Voordijk}

Naar Integrale Logistiek in Bedrijfsketens, Ontwikkelingen in de Bouw 


\section{Paul Diederen}

Technological Progress in Enterprises and Diffusion of Innovations. Theoretical Reflections and

Empirical Evidence.

\section{Ben Dankbaar}

Economic Crisis and Institutional Change. The crisis of Fordism from the perspective of the automobile industry

\section{Hanno Roberts}

Accountability and Responsibility: The Influence of Organisation Design on Management Accounting

\section{2}

\section{Bart Verspagen}

Uneven Growth Between Interdependent

Economies. An Evolutionary View on Technology

Gaps, Trade and Growth

\section{Sjoerd Romme}

A Self-organization Perspective on Strategy

Formation

\section{9}

\section{John Spangenberg}

Economies of Scale, and Atmosphere in Research Organisations

\section{8}

\section{John Hagedoorn}

Evolutionary and heterodox innovation analysis: a study of industrial and technological development in process control and information technology 


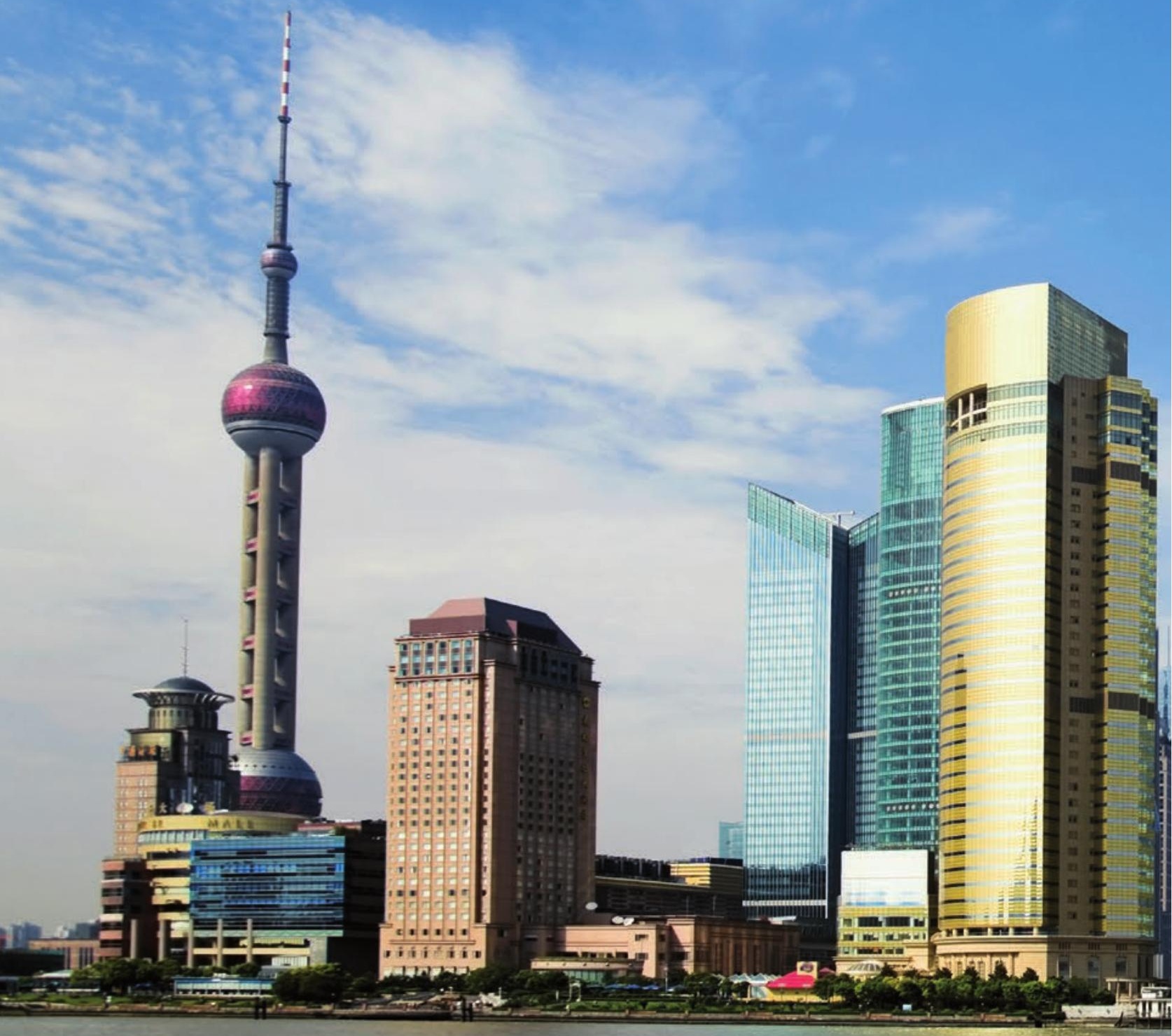

